HISTORY AND POETICS

IN THE EARLY WRITINGS OF

WILLIAM MORRIS, $1855-1870$

$\infty$ 


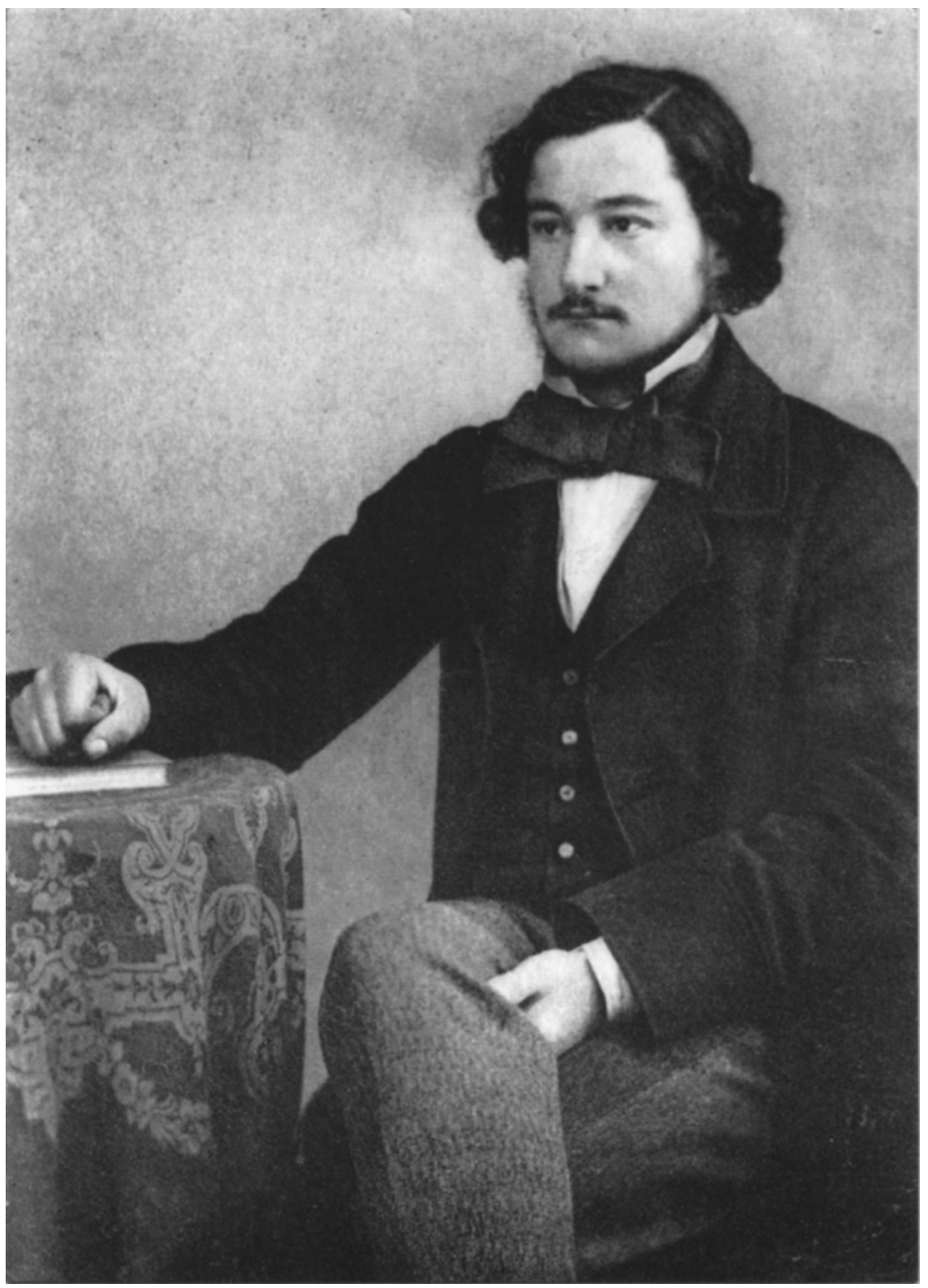

FRONTISPIECE. William Morris in 1857. Courtesy of the William Morris Gallery. 


\section{ISTORY AND POETICS}

IN THE EARLY WRITINGS OF

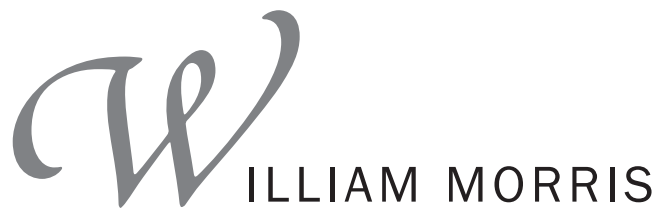

$1855-1870$

\&

FLORENCE S. BOOS

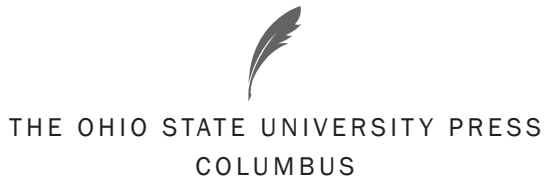


Copyright $\odot 2015$ by The Ohio State University.

All rights reserved.

Library of Congress Cataloging-in-Publication Data

Boos, Florence Saunders, 1943- author.

History and poetics in the early writings of William Morris, 1855-1870 / Florence S. Boos.

pages $\mathrm{cm}$

Includes bibliographical references and index.

ISBN 978-0-8142-1289-9 (cloth : alk. paper) — ISBN 0-8142-1289-1 (cloth : alk. paper) -

1. Morris, William, 1834-1896-Criticism and interpretation. 2. English literature-19th century-History and criticism. I. Title.

PR5084.B66 2015

$821^{\prime} .8-\mathrm{dc} 23$

2015028362

Cover design by Laurence J. Nozik

Text design by Juliet Williams

Type set in Adobe Minion Pro

Printed by Thomson-Shore, Inc.

(2) The paper used in this publication meets the minimum requirements of the American National Standard for Information Sciences-Permanence of Paper for Printed Library Materials. ANSI Z39.48-1992.

$\begin{array}{lllllllll}9 & 8 & 7 & 6 & 5 & 4 & 3 & 2 & 1\end{array}$ 
To William Boos (1943-2014)

Lover of knowledge, truest friend 
List of Illustrations $\quad$ ix

Acknowledgments $\quad$ xi

ONE "If I Can": Morris's Early Writings 1

$\begin{array}{ll}\text { TWO From Antecedents to "Oxford Brotherhood" } & 18\end{array}$

THREE Morris's Earliest Poems: Preparation for The Defence of Guenevere 69

FOUR “The Many Shadows of Amiens”: Morris’s Early Essays 97

FIVE Interlocking Dream Structures in Morris's Early Prose Romances 130

SIX Sources of The Defence of Guenevere 159

SEVEN Gender Polarities in The Defence 195

EIGHT After The Defence: A More Authentic "Medievalism” 231

Appendix Malory’s Guinevere and Morris's Guenevere $\quad 287$

Bibliography 295

Index of Morris's Works Cited 311

$\begin{array}{ll}\text { General Index } & 315\end{array}$ 


\section{FIGURES}

FRONTISPIECE William Morris in 1857

1 Oxford High Street $1875 \quad 30$

2 Exeter College Chapel, under construction 1854-56 31

3 William Morris, early self-portrait 32

4 Edward Burne-Jones, drawing by Simeon Solomon 32

5 Edward Burne-Jones 33

6 R. W. Dixon 34

7 Charles Faulkner 34

8 Cormell Price 35

9 Philip Webb 36

10 Vernon Lushington 37

11 Autograph MS. of early poem, "Drowned," BL 45, 298A, folio 45

12 "Pray But One Prayer for Me," Oxford and Cambridge Magazine, October, p. 644

13 The Oxford and Cambridge Magazine, August 1856, cover 111

14 Amiens in 1855, photograph by Édouard Baldus (1813-89) 114

15 Front view of Amiens Cathedral 115 
16 Edward Burne-Jones, “The Knight's Farewell” 177

17 Drawing of Jane Burden by William Morris 197

18 Richard Garnett 235

19 William Morris in 1870, carte de visite 259

20 “As This Thin Thread," B. L. MS. 45, 298A, f. 87

21 St. Brendan's Voyage, illuminated manuscript 266

22 Sir John Mandeville, 1459 illustration 267

23 William Morris, by Charles Murray, $1870 \quad 283$

\section{PLATES}

1 Picture of John Ball, detail of Froissart's Chronicles, unknown medieval artist

2 Henry Hart Milman, author of The History of Latin Christianity, 1855, George Frederick Watts

3 A. C. Swinburne, by George Frederick Watts

4 Tile of the Seasons, Morris and Co.

5 Harvester, from Tile of the Seasons, Morris and Co.

6 “The Blue Closet," Rossetti watercolor

7 "The Tune of Seven Towers," Rossetti watercolor

8 St. George and the Princess Sabra cabinet, Morris and Co.

9 First page of The Defence of Guenevere, Kelmscott edition, 1892

10 Morris painting, "La Belle Iseult"

11 D. G. Rossetti, "King Arthur's Tomb"

12 Red House, front view

13 Red House, back view

14 "Penelope" wall hanging (left), The Daisy Curtain (right), photograph by R. G. Wilson

15 "Sir Tristram and La Belle Ysoude Drinking the Love Potion," Morris and Co.

16 The Book of Verse, composed and illuminated by Morris, 1870

17 William Morris by George Frederick Watts, 1870 
his book was long in gestation, but it is a pleasure to record its many debts.

Many years ago as a graduate student I delivered my first MLA talk at a session of the U.S. William Morris Society. Countless talks, visits, and research trips later, I am grateful to the Morris Societies in Britain, Canada, and the United States, which have provided me with the sense of a wider audience for Morris's works and brought me friends who have been generous with advice, knowledge, and encouragement. It was also the UK Morris Society that in 1980 granted me and my family the unique opportunity to spend a summer in William Morris's Kelmscott House on the Thames, an opportunity no longer available to scholars. On these early visits I became intrigued by the many Morris autograph drafts that rested unheeded in the British Library and elsewhere. I began to collect the manuscripts which would later prove useful in creating the William Morris Archive and in understanding Morris's developing style and thought.

Over the years I've benefited from listening to several generations of students at the University of Iowa as they responded to Morris's writings. I am also grateful to the English Department and Graduate College of the University of Iowa for awarding me several developmental fellowships and Arts and Humanities Initiative Grants that furthered my Morris projects. 
I owe thanks to the Special Collections and Interlibrary Loan librarians at the University of Iowa Libraries for their resourceful labors on my behalf, as well to the librarians and other staff members of the British Library and the Fitzwilliam Museum Reference Library in Cambridge. Kim Maher has been unfailingly helpful in the preparation of illustrations. To Sandy Crooms, the former acquisitions editor of The Ohio State University Press, I owe a special debt for her early interest in this project, and I am also grateful to Lindsay Martin, the current editor, for her meticulous help in guiding it through the final stages.

Among the friends whose insights and knowledge have helped shape this book, I would especially like to mention Linda Hughes, Mark Samuels Lasner, Jan Marsh, Frank Sharp, David Latham, Elizabeth Helsinger, Elizabeth C. Miller, Peter Faulkner, Lorraine Kooistra, Peter Wright, and the late Norman Kelvin. For welcoming hospitality during earlier visits, I also remember fondly several no longer living: Stan Shipley, Richard Smith, Leo Young, and Ray Watkinson.

Most of all I thank my late husband, William Boos, a mathematician and philosopher who died unexpectedly this past year. Though he cannot see this book in final form, he was its chief enabler. Bill shared my respect for Morris, accompanied me on many research trips to Britain and elsewhere, and brought his editorial skills and critical acumen to bear on earlier drafts. In many senses he is the spiritual co-author of this book, and I dedicate it to his memory with abiding gratitude and love. 


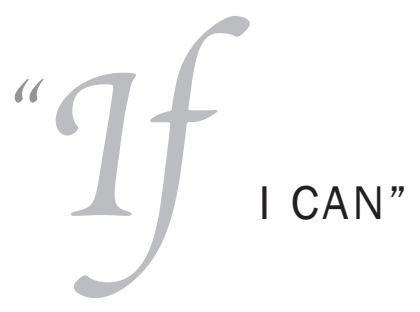

MORRIS'S EARLY WRITINGS

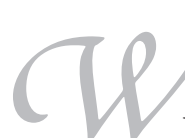

illiam Morris (1834-96) was an artist, poet, translator, romance writer, book designer, and theorist of "The Social Revolution," whose admirers have been drawn to the sheer intensity of his artistic endeavors and efforts to live up to radical ideals of social justice. ${ }^{1}$ Throughout his adult life, Morris also strove to reconcile plainspoken skepticism with infinite yearnings. The resulting "negative capabilities" embraced diffidence and dissidence; detachment and dedication; active resistance and "epoch[s] of rest"; the "Social Revolution" and the "Lesser Arts"; the "idleness" of The Earthly Paradise's "singer"; and the loneliness and ambivalence of all who would "slay ... mighty monsters" (and be slain themselves).

Yet he also "entreated" a despondent friend at one point to "believe that life is not made for nothing, and that the parts of it fit one into another in some way," ${ }^{2}$ and like many nineteenth-century socialists he believed deeply-

1. In preparing this volume I have drawn extensively on the work of J. W. Mackail, May Morris, E. P. Thompson, Fiona MacCarthy, and Norman Kelvin. I have also benefited from access to unpublished manuscript poems from the period during and after the appearance of The Defence in the British Library, Fitzwilliam Museum Reference Library, Huntington Library, and elsewhere. Many of the latter are available in the William Morris Archive. http:// morrisedition.lib.uiowa.edu/earlypoems.html and http://morrisedition.lib.uiowa.edu/ listpoems.html.

2. J. W. Mackail, William Morris and His Circle, 18. 
and perhaps counterfactually-in the innocence and altruism of uncorrupted human nature. ${ }^{3}$ To this leap of secular faith, he added personal ideals of steadfast love and fidelity to cherished ideals, and his literary and political lifework offered homages to both.

Morris's efforts to express these ideals in literary form are similarly varied, ranging from the style of his early Oxford and Cambridge Magazine poems and romances to the personal introspective lyrics of his thirties, the long epics of The Earthly Paradise and Sigurd the Volsung, and his radical critiques of profit-driven societies in the last fifteen years of his life. The two most important shifts in style occurred relatively early: first, the leap between his early poems, romances, and essays and the compressed, allusive, and dramatic poems of his 1858 Defence of Guenevere; and second, between this Defence style and that of later, expansive narrative epics such as The Earthly Paradise. In what follows, I trace these stages of Morris's early literary development, the nature and rationale of these shifts, and his evolving relationship to historical antecedents.

In successive chapters I will examine the influence of Morris's original family and college friendships; his early poems and critical essays and The Defence of Guenevere; and his literary experimentation during the relatively little-studied period between The Defence and The Life and Death of Jason. Along the way I will also consider his attempts to reconcile his artistic ideals and political convictions; his lifelong preoccupation with ancient buildings and deep respect for the unknown artisans who designed and decorated them; his increasing emancipation from contemporary poetic models; his gradual immersion in English, Latin, French, and Old Norse medieval literatures as sources of poetic inspiration; and, finally, his efforts to find a redeeming life-force and justification of these tensions in an egalitarian ideal of human "fellowship."

Collectively, these efforts and preoccupations expressed a persistent desire to create an ethical framework for his artistic and literary endeavors, and they employ multiple points of view and echeloned narrative frames to convey a sense of fragile beauty and integrity. As Morris approached the midpoint of his life, he also began to introduce "poet"/ "singer" figures as guardians of this ethical framework. "Orpheus," for instance, appeared in The Life and Death of Jason and reappeared in "The Story of Orpheus and Eurydice" as a social

3. Compare Kant's despairing assertion that "aus so krummem Holze, als woraus der Mensch gemacht ist, kann nichts völlig Gerades gezimmert werden" (Von der Idee zu einer allgemeinen geschichte in weltbürgerlicher Absicht); "From timber as crooked as that from which humanity is made, nothing completely straight can be constructed" " On the Idea of a Cosmopolitan Universal History"). 
critic, lyric poet, and bereaved but resolute life-partner who would harrow hell to rescue his beloved companion.

Before we examine Morris's early writings, some pervasive features of his thought merit comment: the infusion of religious forms with secular meaning; the tension between the ideals of community expressed in his writings and the isolation experienced by many of his protagonists; and the consistent historicism that underlies his literary work.

\section{Yororis's rejection of formal religion}

Victorians often read contemporary meanings into the records of their ancestors' lives, and the interpretations of religious skeptics as well as believers were steeped in accretions of half-remembered biblical exegesis and iconography. In keeping with this pattern, Morris immersed himself in medieval religious culture as well as its music, poetry, legends, chronicles, architecture, decorative arts, and illuminated manuscripts. ${ }^{4}$ Yet why did this preoccupation with religious culture and ideals stay with him long after he had ceased to find value in any form of Christianity, or indeed in any religion except the "religion of socialism"?

His later alienation from any sort of religious ontology was apparent in Bruce Glasier's record of a visit with him in 1895 , the year before his death. ${ }^{5}$ When Glasier remarked that he had questioned his own agnosticism, Morris responded that

I have never allowed myself to worry about these questions since I was at

Oxford thinking of becoming a parson. ... As far as I can discover from

4. His designs for the Kelmscott Press, for example, took medieval illuminated manuscripts and early printed books as their models, and he continued to collect medieval manuscripts and to enjoy early English music into the last year of his life. Through the Society for the Protection of Ancient Buildings he campaigned for the preservation of medieval art and architecture, and shortly before his death listened intensely to a performance of medieval music on the virginals by Arnold Dolmetsch (MacCarthy, William Morris: A Life for Our Time, 668-69). Succeeding citations to MacCarthy are to this volume unless noted otherwise.

5. Bruce Glasier, William Morris and the Early Days of the Socialist Movement, 171. Glasier has sometimes been charged with attempting to alter Morris's views for his own ends; in this case, however, he found Morris's skepticism disappointing, and so he is unlikely to have exaggerated it. Morris's full statement as quoted is instructive; he explains in simple, colloquial language the sense in which literary and mythological constructs may be "true," and notes that, "But Atheist though I must consider myself when I reason about the matter, my Atheism has as little effect upon my ordinary conduct and work-a-day views of things, as belief in Christ appears to have on the majority of Christians" (171). 
logical thinking, I am what is called bluntly an Atheist. I cannot see any real evidence of the existence of God or of immortality in the facts of the world ... And of this I am absolutely convinced, that if there is a God, $\mathrm{He}$ never meant us to know much about Himself, or indeed to concern ourselves about Him at all. Had He so wished, don't you think He would have made His existence and His wishes so overwhelmingly clear to us that we could not possibly have ever doubted about it at all? ${ }^{6}$

When she studied her father's early drafts for The Earthly Paradise after his death, May Morris characterized his early views as follows:

All the weight, the responsibility of life and its choices [were] revealed to him ... [and] how best to answer to the high sense of duty towards humanity and the beyond: in 1860 he would call it God, later in life the mystery beyond our visible world had no name.

From Glasier's recollections and other sources it is evident that this dating was inaccurate. Cormell Price's diary for May 1855, for example, mentioned that "Morris ha[d] become questionable on doctrinal points," ${ }^{8}$ and Morris wrote to Price the same year that he would not take his degree if he had to attest to the Thirty-Nine Articles (a fortunate change in university regulations came just in time to permit him to graduate). ${ }^{9}$

In an 1884 letter to Robert Thompson, a schoolteacher who inquired into his views of such matters, Morris politely declined "to argue theological points: I don't understand them: if there be a God, he, or it, is a very different thing from what religionists imagine." ${ }^{\prime 0}$ And in "Equality," a lecture he

6. Bruce Glasier, William Morris and the Early Days of the Socialist Movement, 171.

7. May Morris, William Morris: Artist, Writer, Socialist, 1:397.

8. Nicholas Salmon and Derek Baker, William Morris Chronology, 10.

9. Eugene LeMire, "The 'First' William Morris and the 39 Articles." LeMire establishes that as a result of the Oxford University Reform Act of 1854, by late 1855 students were permitted to receive degrees without attesting religious belief, a change that enabled Morris to take his degree in 1856 without such an affirmation. The Act clearly exempted Dissenters and other non-Anglicans from affirmation, but during an interim period some administrators had claimed that Anglicans were still subject to the requirement. It is this controversy that most likely prompted Morris's statement to Cormell in a letter of 1855 that he would neither declare himself non-Anglican nor sign an affirmation of the Articles. Fortunately, a titled Anglican who resented the restriction brought the matter to the House of Lords in the summer of 1855, and the latter ruled that Anglicans shared with non-Anglicans the right to graduate without declaring religious belief. Sir Culling Eardley, Bart. has not gone down in the annals of religious freedom, but his act may have helped permit Morris to receive his degree.

10. Norman Kelvin, The Collected Letters of William Morris, 2:288. 
drafted for delivery in 1888 , he argued that a true commonwealth must dispense with the

cast clout of feudalism [,] the creed of the superior person, . . . i.e., the assumption of the existence of a ... God of the universe[,] the proprietor of all things and persons, to be worshipped and not questioned ... whose irresponsible authority is reflected in the world of men by certain ... [lesser] governors whose authority is delegated to them by that supreme slaveholder and employer of labour up in heaven. ${ }^{11}$

In one of Morris's last public lectures, finally, "Communism-i.e. Property" (dated by May Morris in 1893), he remarked even more bluntly that "Religion is gone down the wind, and will no more cumber us unless we are open fools." 12

These were strong views for a nineteenth-century figure from a religious family who had briefly considered a clerical career. Morris's mother and at least two of his sisters were deeply devout, ${ }^{13}$ his mother imposed a regime of grace-saying in which everyone at table was expected to kneel, ${ }^{14}$ and May Morris later recalled her grandmother's proud assertion that her gifted son "might have been a Bishop now!"15

In brief, Morris was not simply a mildly skeptical "art-catholic," and his art-historically grounded interests were as revisionist in content as they were traditional in form. Elizabeth Helsinger has characterized Pre-Raphaelitism as responding to the past through "repetition" and "translation," appropriation of religious art embodied both in its harmonious blending of Christian materials with other literary and quasi-historical sources. Morris believed that the letter killeth but the spirit giveth light, and his many expressions of solidarity with Christian artisans expressed kinship with the spirit of their ideals, not their letter. ${ }^{17}$

11. William Morris's “Equality: A Critical Edition," ed. Florence Boos, Journal of PreRaphaelite Studies, n.s. 20 (Spring 2011): 51-70.

12. Boos, "From the Archive: 'Communism-i.e. Property': A Partly Unpublished Morris Essay," 18.

13. Morris complained to Andreas Scheu of the "rich establishmentarian Puritanism" of his youth (Kelvin, Letters, 2:227). Henrietta converted to Roman Catholicism and Emma to High Church Anglicanism; nothing is known of the religious views of Morris's brothers.

14. William Morris, Collected Works ( $C W$ hereafter), 4:Xv.

15. Ibid., xvii.

16. Elizabeth Helsinger, Poetry and the Pre-Raphaelite Arts, 2.

17. John Hollow has argued that several of Morris's early prose romances and Defence poems-among them "Lindenborg's Pool," "The Hollow Land," and the Launcelot/Guenevere poems-presented attempts to read God's "judgments," in order to demonstrate that "men who 


\section{OVE" AND STRIFE}

There was a sense in which Morris's early searches for "love" and "fellowship" in the medieval past led him into a darkling plain. Several of his poet heroes gave their lives for their fellows, but solidarity and mutual aid were remote ideals in the 'real' world of The Defence. In their place was a pervasive sense of struggle and, often quite literally, siege-in "Sir Peter Harpdon's End," for example, or "Scenes from the Fall of Troy"-in which male members of the lesser nobility fought for their livelihoods by slaughtering their 'fellows' a few fiefdoms away, and they or their consorts became temporarily or permanently deranged. Those who did not were painfully aware that their hopes might be deluded, their failures might destroy those they loved, and love itself might wither away to half-"remembered kisses after death." ${ }^{18}$

When he was young Morris seemed to succumb at times to an oppressive sense of entrapment, and his extensive readings in accounts of the Hundred Years' War (Jean Froissart, Enguerrand Monstrelet, Philippe de Commynes) reinforced his view of medieval life as one of constant siege and motivated his tributes to those killed in war (Amyot in "The Story of the Unknown Church" and the fleeing lovers in "Concerning Geffray Teste Noire"). Recent accounts of political strife on the continent and pitched battles in the Crimea may also have hovered in the back of his mind, reinforced by the interests of several of his early Oxford friends and associates. ${ }^{19}$ The Oxford and Cambridge Magazine, conducted by Morris and his fellow Oxford "Brothers," published Harry Macdonald's review of Sydney Dobell's 1856 England in Time of War and two articles by R. W. Dixon on Britain's politics in the Near East, and Edward Burne-Jones recalled that in a particularly depressive moment he had applied for a commission "to go and get shot in the Crimea." ${ }^{20}$ Two of Morris's four brothers later held military commissions, and during the winter of 1859-60,

concern themselves about God's judgments tend to take their own judgments for His, since even if God exists he does not give signs of his will" ("William Morris and the Judgment of God," 450).

18. Alfred Tennyson, “Tears, Idle Tears," 1l. 16-17, in Christopher Ricks, The Poems of Alfred Tennyson, London: Athlone, 1986, 784-86.

19. Vernon Lushington, a contributor to The Oxford and Cambridge Magazine, published a treatise justifying war in the Crimea in 1855, How Shall the Strong Man Use His Strength, or the right and duty of war, with application to the present crisis (London, 1855). Like Morris, Lushington was later to repudiate imperialism. See David Taylor, "Vernon Lushington: Practicing Positivism," Diss., University of Roehampton, 2008, 112.

20. Frances Horner, Time Remembered (London: Heinemann, 1933), 12; Georgiana BurneJones, Memorials of Edward Burne-Jones, 1:109-10. Fortunately Burne-Jones was rejected on grounds of health. 
in a period when Britons worried about a possible invasion from France, Morris joined his friends and colleagues in the "Corps of Artist Volunteers."

Did Morris depict so many desolate scenes of unremitting struggle because he found them attractive? Or was it because he identified in some cathartic way with their anxious and threatened protagonists? The latter seems more likely, and I will argue that the intensity of his commitment to 'the Social Revolution, from his involvement in an antiwar movement in the late seventies to his death in 1896 , was driven by an equally intense sense of empathy for all who inflicted and endured the brutality of war.

\section{Morris's “historicism” and medievalism”}

Morris was the most consistently 'historicist' of the major Victorian poets, so it may be useful to examine briefly some of the views he shared and did not share with medieval historians whose works he read. All the reviewers of The Defence of Guenevere, Morris's first volume of poetry, hostile and favorable alike, considered his work strikingly "medieval." Among the favorable, for example, Richard Garnett thought

the difference between [Tennyson and Morris] is that Tennyson writes of mediaeval things like a modern, and Mr. Morris like a contemporary. Tennyson's "Sir Galahad" is Tennyson himself . . . ; Mr. Morris's is the actual champion, just as he lived and moved and had his being some twelve hundred years ago. Tennyson is the orator who makes a speech for another; Mr. Morris the reporter who writes down what another man says. ${ }^{21}$

Garnett's praiseful response itself was an act of benevolent faith: how, after all, could a Victorian 'know' the consciousness of a medieval knight or artisan, much less recognize such 'knowledge' in someone else? Still, his wry comparison in the last sentence was apt in its recognition of Morris's radical dissociation from the medievalizing models of his own age.

Morris had inserted authorial prayers at the end of "Sir Peter Harpdon's End" and "In Praise of My Lady", for example, in apparent emulation of his medieval predecessors. But he had also introduced a kind of dialektike between himself and his putative medieval narrator, a device that permitted him to use the 'alterity' of the medieval past to critique the present, and the

21. Literary Gazette, April 1858, 226. 
'alterity' of the present to critique the past. If one takes this dialectic seriously, the resulting hall of mirrors raises deep philosophical questions about our abilities or inabilities to grasp the nature of "other minds" past or present. In his 1979 essay "Marxism and Historicism," Fredric Jameson posited several entrances into such halls of mirrors, among them nostalgia, antiquarianism, existential historicism, and utopian hope. Morris's writings embody all these approaches. $^{22}$

\section{A. contemporary PARALLEL: WILHELM DILTHEY}

Antecedents of Morris's historicism in the works of Thomas Carlyle and John Ruskin are well known, ${ }^{23}$ but contemporary parallels may also be found in the work of a German he never met, and whose writings he almost certainly never read. The principal nineteenth-century theorist of empathetic historicism was Morris's longer-lived contemporary Wilhelm Dilthey (1833-1911), whose account of "the human sciences" probed the epistemological and emotional premises that underlie attempts to 'reinhabit' the past. Dilthey posited that human beings have a sense of the "value" of things in the present and confront the future with "purpose," but can only ascribe "meaning" to human expressions in evocations of the past. In Dilthey's words, "it is especially important that lived experience be comprehended as a unity in memory. ... The meaning of life provides an inner bond between poetry, religion, and philosophy." ${ }^{4}$

In "The Understanding of Other Persons and Their Life Expressions," Dilthey argued that a kind of innate "Verstehen" ("understanding") enables us to

22. For a discussion of more recent approaches to historicism, see Lauren M. E. Goodlad and Andrew Sartori, “The Ends of History: An Introduction," Victorian Studies 55.4 (Summer 2013): 591-614. A thorough study of Morris's later approach to history appears in chapters 3 and 4 of Anna Vaninskaya, William Morris and the Idea of Community: Romance, History and Propaganda, 1880-1914, "The Dark Ages" and "The Middle Ages." An account of the origins of Morris's historicism in the Gothic revival, including the medievalism of Pugin, Cobbett, Carlyle, and Ruskin, appears in Marcus Waithe, William Morris's Utopia of Strangers: Victorian Medievalism and the Ideal of Hospitality.

23. "There were a few who were in open rebellion against the said Whiggery-a few, say two, Carlyle and Ruskin. The latter, before my days of practical Socialism, was my master towards the ideal aforesaid, and, looking backward, I cannot help saying, by the way, how deadly dull the world would have been twenty years ago but for Ruskin!" ("How I Became a Socialist," $C W, 23: 279)$. For a discussion of the influence of "The Nature of Gothic" on Morris, see chapter 4 in this volume.

24. Wilhelm Dilthey, "Fragments for a Poetics," in Selected Works, 5:231. 
interpret the "expressions" of other human beings (works of art, history, and literature, for example) in ways that deepen our own awareness of human identity. "Judgments" or rational deductions, by contrast, offer no information about the inner life, and actions only express part of our being. But a "spontaneous expression of experience" may be perceived directly, for a "special relationship exists between it, the life from which it comes, and the understanding which grasps it," and such "spontaneous expression . . . contains more of mental life than can be comprehended by introspection. It lifts mental life out of depths that consciousness cannot illuminate." 25 Our culturally inflected projections and identifications with the mental and emotional lives of others also create higher levels of awareness of our own nature(s) which no direct "self"-examination could provide, and our "transposing, reconstructing, reliving, these facts point to the totality of mental life." 26

Morris presumably knew nothing of Dilthey, but he would certainly have agreed that our attempts to reconstruct the past may also reconstruct $u s$ in successive wave fronts of awareness-a beneficial variant of the "hall of mirrors" mentioned earlier. Dilthey also observed that such reconstructions are not "true" or "false," but only "sincere or insincere" ("aufrichtig oder unaufrichtig") — cardinal virtues for Morris - in ways that invite further interpretation. ${ }^{27}$

When in great works of art, a mental event is freed from its creator, we enter an area in which illusion and deception no longer exist. ... Thus in the area between act and knowledge arises a circle in which life reveals depths which observation, reflection, and theorizing are unable to penetrate. ${ }^{28}$

Dilthey affirmed that such artistic projections can give rise to meanings beyond those present to a given poet's or artist's consciousness, and that these later meanings may acquire a valid aesthetic, psychological, and atemporal "reality"-a clear anticipation of one of the central tenets of "reader-response criticism." ${ }^{29}$ Citing Friedrich Schleiermacher's claim that "it is possible to

25. Wilhelm Dilthey, Collected Works, Stuttgart: Teubner Verlagsgesellschaft, vol. 7, trans. J. J. Kuehl, in Theories of History, ed. Patrick Gardiner (New York: Free Press, 1965), 223.

26. Ibid., 223. He continues, "So in every understanding, there is something irrational, as life itself is irrational; something is incapable of being fully represented by a logical formula" (223).

27. Cf. also Hayden White's Metahistory: The Historical Imagination in Nineteenth-Century Europe (Baltimore: Johns Hopkins University Press, 1973).

28. Dilthey, “The Understanding of Other Persons," 214-15.

29. A twentieth-century theorist of historical transmission who may never have heard of Morris, in turn, was Hans Robert Jauss (1921-97), who argued in his oft-cited "Literary History as a Challenge to Literary Theory" (1979) that aesthetic works are subject to shifting "horizon[s] 
understand an author better than he understands himself," finally, Dilthey also argued that "expressions of experience contain more than lies in the consciousness of the poet or artist, and thus evoke more in the spectator as well." ${ }^{30}$

In Dilthey's view such existential "understanding" was ultimately individual, and "the individual is an object of absolute value, and indeed . . . the only such value that exists." ${ }^{31}$ Morris would have rejected the hyperbolic second assertion as written, but agreed that the enigmas of other minds (and our own) remain sources of wonder and emergent value.

The secret of the individual draws us, for its own sake, into ever new and more profound attempts to understand it, and it is in such understanding that the individual and mankind in general and its creations are revealed to us. ${ }^{32}$

Dilthey also believed that retrospective analysis is less meaningful than "re"-creation:

Complete empathy is dependent on the possibility of the understanding following the order of the events themselves. ... To relive is to create in the same direction as the original events. ... The reliving is complete when the event has passed through the consciousness of a poet, artist, or historian, and lies fixed and enduring before us in their work. ${ }^{33}$

Morris would have vigorously assented to the last sentence as well as to Dilthey's assertion that

the course of life exercises a determining influence on every man, by which the possibilities which lie within him are narrowed down ... he finds that the prospects of a new outlook on life, or further inner development of his personal character, are limited. But understanding opens to him a whole new realm of possibilities... The possibility of having religious experience

of expectations" in "literary series" of changes. Literary works can "interact with the special histor[ies]" of their reader's lived experiences; foster "emancipation of mankind from its natural, religious, and social bonds"; and "solve formal and moral problems left behind by [previous works] and present new problems in [their] turns $(1555,1564)$." Such views echo the Victorian faith that artistic reinterpretations of the past are potential salutary interventions in the present and future.

30. Dilthey, in Gardiner, Theories of History, 220, 223.

31. Ibid., 219.

32. Ibid.

33. Ibid., 220. 
is circumscribed for me, as it is for most people today ... But I can relive it. . . Man, who is bound and determined by the realities of life, is not only liberated by art—this has often been said—but also by the understanding of history. ${ }^{34}$

Morris in particular felt a sense of entrapment in the present, as well as an identification with, though not literal belief in, medieval religious ideals. But Dilthey's words likewise reverberate with other Victorian protests against fixed identity and nostalgia for a past religion, as the speaker of Matthew Arnold's "Dover Beach" regrets the loss of the Sea of Faith, which "round earth's shore / Lay like the folds of a bright girdle furled," and Gerard Manley Hopkins mourns the constraints of a fixed identity:

[t]he lost are like this, and their scourge to be

As I am mine, their sweating selves, but worse. ${ }^{35}$

\section{HE “INNER TRUTHS” OF HISTORY}

Morris's personal views of history embraced several Diltheyan tenets and observations. One was that historical records contained inner "truths" reflected in music, writings, and works of art. Another was that such "truths" or "insights" are and should be multiply and infinitely interpretable. A third, finally, was that artists and writers can (and should) make ethically defensible judgments about these "interpretations"-or in Morris's words, "shut the book[s] and write [them] again in your own way." ${ }^{36}$

Deeply embedded within Victorian culture was the practice of reading contemporary meanings into the records of past lives, and Carlyle, Ruskin, and (later) Walter Pater advocated variants of these approaches. When he recalled his mid-Victorian youth in "How I Became a Socialist," Morris recalled that "there were a few who were in open rebellion against the said Whiggery-a few, say two, Carlyle and Ruskin.” Carlyle's 1843 Past and Present had advocated retrospective/anticipatory readings, claiming that an understanding of the medieval past will give his readers "hope of . . illustrating our own poor Century." ${ }^{37}$ More boldly, he had evoked a secular faith in time as

\footnotetext{
34. Ibid., 221-22.

35. "Dover Beach," 11. 21-23; "I Wake and Feel the Fell of Day," 1l. 13-14.

36. $C W$, 3:xxii.

37. Past and Present, bk. 2, chap. 1, p. 45.
} 
a totum simul ("everything at once," Boethius's definition of "eternity"): "The Present holds in it both the whole Past and the whole Future, .. . [and] in all times and places is one and the same Life-tree!" ${ }^{8}$ Carlyle's claim that true heroism is found in the interstices of conventional history was applicable to artists, craftsmen, and ordinary people as well as the more prominent individuals he himself singled out. ${ }^{39}$ Above all, Carlyle's conception of the "hero as prophet"- that is, the belief that the writer's mission was to discern and apply the signs of the times to his own present, was shared in varying degrees by the nineteenth-century historians read by Morris as well as Morris himself.

Likewise, Pater would argue in "Giorgione" that the "truths" of such 'insights' are measured by the value(s) critics and reflective observers find in them,$^{40}$ views of course directly in the line of modern reception theory. Similarly Morris argued, with Dilthey, that inner experiences of history "lived on" in reflective and imaginative reconstruction. Works of art could and should redress past silences and critique what they celebrate-weave into their narratives the "truths" of faithful retainers such as Sir Peter Harpdon, as well as the faits et gestes of their celebrated sires (Sir Launcelot). In the process they could explore the contradictions and accidents of transmission of, for example, the tale of Troy, for such narratives might bring a small measure of redress to ordinary persons such as pike-carriers, trapped in "the pity of war."

Such efforts to "hold ... up . . . things that fall" and render homage to the frustrations and desires of ordinary people could themselves be efforts of historical intervention, and Morris set down his conviction that this was so in lectures with titles such as "Medieval England," "Gothic Architecture," "The Early Literature of the North," "Architecture and History," "The Origins of Ornamental Art," and "Some Notes on the Illuminated Books of the Middle Ages." In them, he argued that "real history . . . is no dead thing, but the living bond of the hopes of the past, the present, and the future," ${ }^{11}$ a

38. Ibid., bk. 1, chap. 6, p. 42 .

39. Morris's early attention to Carlyle may have been reinforced by the enthusiasm of his friend and fellow Oxford and Cambridge Magazine contributor Vernon Lushington, who had championed Carlyle as the pioneer of a new and relevant form of history. The second of Lushington's five articles on Carlyle for the Magazine argued for his value as a historian: "Carlyle's work is of a different kind from ordinary historical work, altogether something new and wonderful .... How is it, that he can make the old dead past a new and beautiful, and living Wonder-land?" (May 1856, 300).

40. First published in the Fortnightly Review, 1877; Walter Pater, The Renaissance: Studies in Art and Poetry; the 1893 Text, ed. Donald L. Hill (Berkeley: University of California Press, 1980).

41. "On the Origins of Ornamental Art," in Norman Kelvin, William Morris on Art and Socialism, 167. 
"living bond" that called for active intervention in the present. ${ }^{42}$ This radicaldemocratic theory of history was already present in "The Lesser Arts" (1877), in which he interpreted history not as a record of the transmissions and betrayals of power but as the material culture of ordinary people:

Nor must you forget that when men say popes, kings, and emperors built such and such buildings, it is a mere way of speaking. You look in your history-books to see who built Westminster Abbey, who built St. Sophia at Constantinople, and they tell you Henry III, Justinian the Emperor. Did they? or, rather men like you and me, handicraftsmen who have left no names behind them, nothing but their work? ${ }^{43}$

One might interpret searches for ethical and political relevance in historical narratives as secular counterparts of the appeal for guidance to a seventeenth-century English translation of ancient Hebrew and Aramaic texts ("Except in parables he spake not to them"). Such appropriations could be used to bless canons in both cases, of course, but they could also, Morris came to realize, enable individuals to act in accordance with "the hopes of the past, the present, and the future," or at least search within them for what Ernst Bloch would later call "anticipations of the not-yet." ${ }^{4}$

From adolescence onward, Morris's historical readings were prodigious in detail. Beyond studies of art and architecture, they included Edward Gibbon's History of the Decline and Fall of the Roman Empire, J. C. L. Sismondi's History of the Fall of the Roman Empire, H. H. Milman's History of Latin Christianity, John Mason Neale's A History of the Holy Eastern Church, John Stow's Survey of London, Samuel Laing's translation of the Heimskringla, or History of the Kings of Norway, William of Malmesbury's Chronicle of the Kings of England, and detailed accounts of the Hundred Years' War by Jean Froissart, Enguerrand de Monstrelet, and Philippe de Commynes. Some of these treatises' recreations of dynastic and theological conflicts were (as Morris would have noticed) minor literary epics, told with dramatic skill and with a rich inlaid excursus into the anthropology and archeology of their periods.

42. He also believed throughout his life that literary transmission should not be constrained by pedantry and obtrusive explanation. In preparing the Kelmscott Chaucer, for example, he published W. W. Skeat's newly edited text without notes so that readers could encounter the text 'as it was.' Other considerations-whether Chaucer had actually written all the texts ascribed to him, for example-were secondary. Cf. Charles LaPorte, "Morris's Compromises: On Victorian Editorial Theory and the Kelmscott Chaucer."

43. "The Lesser Arts," CW, 22:6-7.

44. Ernst Bloch, Das Prinzip Hoffnung. For a similar concept of the Jetztzeit-“a past charged with the time of now"- see Walter Benjamin, "Theses on the Philosophy of History." 
In his six-volume History of Latin Christianity, for example, H. H. Milman (1781-1868), a poet and dramatist as well as cleric, ${ }^{45}$ offered a stringent social and political critique of the conflicts and legal decrees of the men who ruled in the name of Christ and the priests who served them. Of Christian treatment of slaves, for example, he remarked that

the abrogation of slavery was not contemplated even as a remote possibility. A general enfranchisement seems never to have dawned on the wisest and best of the Christian writers, notwithstanding the greater facility for manumission, and the sanctity, as it were, assigned to the act by Constantine, by placing it under the special superintendence of the clergy. ${ }^{46}$

In other passages Milman critiqued the severity of criminal punishments, decried rulers' readiness to exploit mass prejudices, and assessed the degree of tolerance they accorded to practitioners of non-Christian religions. He also described in horrific detail the tortures inflected by the French king to extract "confessions" of their alleged "perversions" from the Templars (in order to appropriate their properties), and remarked mordantly that "it [was] said, in the unintentional irony of the historian, [that] some willingly confessed, though others died without confession." ${ }^{47}$

In his study of The Fall of the Roman Empire, the Italian economist J. C. L. Sismondi approached his period and subject in a similarly skeptical manner and with roughly similar conclusions:

Heirs of a form of civilisation completely different from our own; heirs of the most heterogeneous social elements, of the most opposite recollections and feelings, it is imperative upon us to go back to the origin of things, and to behold whence we have sprung, that we may understand what we are..$^{48}$

No harmful custom should be permitted to hide behind tradition:

45. Henry Hart Milman was Dean of St. Pauls 1849-68. A recipient of the Newdigate Prize and former Professor of Poetry at Oxford, Milman was an editor of Edward Gibbon's Decline and Fall and author of a History of the Jews (1829), criticized in its time for its relatively nonpartisan approach, and the History of Christianity to the Abolition of Paganism in the Roman Empire (1840).

46. History of Latin Christianity, chap. 6, p. 14; chap. 5, p. 14.

47. Milman, bk. 12, chap. 1, 202.

48. Sismondi, The Fall of the Roman Empire, Comprising a View of the Invasion and Settlement of the Barbarians (Philadelphia, 1835), chap. 24, p. 253. 
The portion of history of which we shall endeavour to give a rapid sketch is, indeed, more rich in instructive warnings than in glorious examples. [. . .] History, however profoundly studied, will still, perhaps, leave us in doubt as to the rules which ought to regulate our own conduct . . . but it will leave us none as to the boundless indulgence we owe to the opinions of other men.... when we are not sure of our own footing, how shall we pronounce sentence on those who differ from us? ${ }^{49}$

Like Milman, Sismondi also paused to note individual instances of dignity and heroism, but his overall judgments of human character in a time of warfare were at least as bleak as those expressed by the author of The Defence of Guenevere. With the exception of "the first followers of Mahomet, who braved every danger to spread the doctrine of the unity of God," he observed that

the rest, whether captains or soldiers, whether conquerors or conquered, fought only for themselves; for their own interest, their own advancement. They might be brave, they might be skilful; but they had no pretensions to heroism. In like manner, kings, ministers, legislators, the founders and the destroyers of empires ... sacrificed not themselves to others, but others to themselves; and they esteemed humanity, loyalty, all the virtues, all the nobler affections, of less weight than their personal interests. ${ }^{50}$

Sismondi reserved his deepest contempt for early medieval Christianity, whose "hostile sects too often transform a bond of peace and love into a weapon of aggression and hostility." ${ }^{11} \mathrm{He}$ addressed his final appeal to an ideal of social unity for the common good, not unlike Morris's notion of "fellowship," with the hope that future historians may record men "once more devoting themselves to the service of their fellow citizens and continually gaining new virtues from self-sacrifice." 52

Especially important for Morris was the narrative of the Hundred Years' War in Jean Froissart's Chronicles of England, France, Spain and the Adjoining Countries. ${ }^{53}$ Froissart's dramatic account of unrelieved warfare, with its many

49. Ibid., chap. 1, p. 10.

50. Ibid., chap. 24, pp. 481-82.

51. Ibid., chap. 1, p. 24.

52. Ibid., chap. 24, p. 482.

53. Froissart, The Chronicles of England, France, Spain ..., trans. T. Johnes (Smith, Elder, London, 1839). Froissart's account, written for, among other patrons, Edward III's consort Queen Philippa, describes events from an English viewpoint, celebrating the military prowess of Edward III's armies. A modern reader may well view Edward III as a titled marauder, eager 
eyewitness reports and invented dialogues, found many echoes in The Defence of Guenevere. A fourteenth-century court historian, Froissart was a privileged clerk who expressed few sympathies for the sufferings of the poor. But the accounts in his Chronicles of the Hundred Years' War and the revolts of the French Jacquerie in 1358 and English Peasants' Uprising of 1381 provided templates for the wars and intrigues in Morris's Defence of Guenevere, as well as the fates of the villeins and artisans who tried to survive them.

One such template became the source of Morris's beautiful "sermon at the crossroads" in A Dream of John Ball. In modern English translation, it reads as follows:

Good people, things cannot go right in England, and never will, until goods are held in common and there are no more villeins and gentlefolk, but we are all one and the same... . If we all spring from a single father and mother, Adam and Eve, how can they claim or prove that they are lords more than us, except by making us produce and grow the wealth which they spend? ... And from us must come, from our labor, the things which keep them in luxury. . . . Let us go to the King-he is young-and show him how we are oppressed, and tell him that we want things to be changed, or else we will change them ourselves. If we go in good earnest and all together, very many people who are called serfs and are held in subjection will follow us to get their freedom..$^{54}$

As his English translator and editor Geoffrey Brereton observed, Froissart "condemn[ed] John Ball very strongly as a trouble-maker-but at least he g[ave] him a hearing." ${ }^{55}$

\section{ONCLUSION}

Like most idealists, William Morris believed that emotion liberated by transcendence and renewal manifests a rare beauty, even when it "fail[s] in the

for the plunder and wealth gained from ransom while ignoring the pangs of his victims and the sacrifices of his army; even Froissart presents occasions on which his rage or vindictiveness alarms even his counselors, who urge him to refrain from acts of murder, if only to avoid offending a church emissary or inciting revenge.

54. Froissart, Chronicles, ed. Brereton, 212. An online version of the Johnes edition is available at http://name.umdl.umich.edu/ACG8357.0001.001 [accessed 26 May 2015].

55. Ibid., 21. 
world." Like most socialists, he also believed (or hoped) that human altruism and solidarity could prevail in still-counterfactual but eventually attainable conditions. What set him apart from his 'fellows' was an uncommon ability to portray the beauty and vulnerability of human desires, freed briefly in an epiphanic world of particularized and sensory radiance.

As a source for this portrayal, Morris also manifested a consistent preoccupation with history, to the extent it was available to him, and an unwavering personal allegiance to "authenticity" and empathetic interpretation. In service to these ideals, he turned from the more romantic fictions of Friedrich de la Motte Fouqué, Charles Kingsley, and Charlotte Yonge to a serious study of the poetry of his nineteenth-century predecessors and contemporaries, fusing their modernized treatment of medieval legends with his own linguistic intensity. Later, after the publication of The Defence of Guenevere, he set out more firmly to chart his own historical and personal paths. These prompted him both to lifelong systematic study of source material in French, Latin, Greek, Anglo-Saxon, Middle English, and Old Icelandic, and perhaps unexpectedly, to more personal forms of expression. As he attempted a more "authentic" medievalism, moreover, Morris strove to refine in varied lyric and epic registers his presentations of multiple viewpoints, empathetic narrators, and fragmented identities that survived the dislocations of time.

Fairly early in his life, finally, Morris tempered his attraction to the best ideals of the past with a deepening awareness of the cruelty of its wars and social hierarchies, and a conviction that artistic empathy was also a fragile effort to "hold ... up . . . things that fall." The wave of failed bourgeois revolutions in Europe lay in the very recent past, and Morris evinced his contempt for the oppression of women as well as men, and for the thinly disguised machinations of "popes, kings, and emperors" in his earliest essays and poetic efforts.

As his insights into these moral and psychological complexities evolved, Morris widened the ranges of his lyric and epic registers; defended broader and more uncompromising views of 'art'; raised the intensity of his youthful commitment to radical egalitarian ideals; and deepened his temperamental admiration for all the "lesser arts" as testaments of those who wrought them (not those who commissioned them). In all these endeavors, he remained, in the words of his first biographer, "one who, in an age of transition and confusion, set a certain ideal before him and pursued it, through the many paths by which it led him, with undeviating constancy." ${ }^{36}$

The following chapters consider the early stages of this pursuit.

56. Mackail, Life of William Morris, 1:1. 


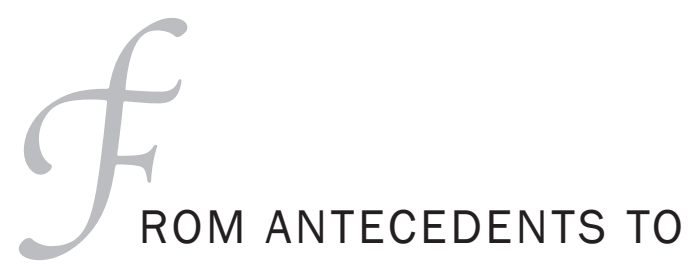

“OXFORD BROTHERHOOD” relevant to an understanding of his later aims and accomplishments. Much of what little is known about his youth derives from his own recollections, a memoir by his college friend R. W. Dixon, ${ }^{2}$ May Morris's brief sketches in the introduction to volume 1 of the Collected Works and in William Morris: Artist, Writer, Socialist, Georgiana Burne-Jones's Memorials to her husband, ${ }^{3}$ and the notes and published account of his first biographer, J. W. Mackail, ${ }^{4}$ who drew in turn on the recollections of his in-laws Edward and Georgiana Burne-Jones.

Morris's awareness of privileges he had enjoyed and endured were evident in the only autobiographical sketch we have, in an 1883 letter to his fellow socialist, the Austrian furniture designer Andreas Scheu: ${ }^{5}$

\footnotetext{
1. Letter to Cormell Price, July 1856, Kelvin, Letters, 1:28.

2. R. W. Dixon, "Memoir of William Morris by R. W. Dixon," ed. Florence Boos.

3. Georgiana Burne-Jones, Memorials of Edward Burne-Jones.

4. J. W. Mackail, Notebooks WMG no. 54, notebooks 4 and 5; The Life of William Morris.

5. Kelvin, Letters, 2:227-31.
} 
I was born at Walthamstow in Essex in March 1834, a suburban village on the edge of Epping Forest, and once a pleasant place enough, but now terribly cocknified and choked up by the jerry-builder.

My father was a business man in the city, and well-to-do; and we lived in the ordinary bourgeois style of comfort; and since we belonged to the evangelical section of the English Church I was brought up in what I should call rich establishmentarian Puritanism; a religion which even as a boy I never took to.

I went to school at Marlborough College, which was then a new and very rough school. As far as my school instruction went, I think I may fairly say I learned next to nothing there, for indeed next to nothing was taught; ${ }^{6}$ but the place is in very beautiful country, thickly scattered over with prehistoric monuments, and I set myself eagerly to studying these and everything else that had any history in it, and so perhaps learned a good deal, especially as there was a good library at the school to which I sometimes had access. I should mention that ever since I could remember I was a great devourer of books. I don't remember being taught to read, and by the time I was 7 years old I had read a very great many books good, bad and indifferent.

My Father died in 1847 a few months before I went to Marlborough; but as he had engaged in a fortunate mining speculation before his death, we were left very well off, rich in fact. ${ }^{\text {? }}$

May Morris's descriptions, by contrast, were a roseate blur of warm generic stereotypes: ${ }^{8}$

The whimsical play-world of a numerous and united family does not interest anyone outside the circle, but certainly the doings and sayings of those boys and girls who lived happily on the edge of the Great Forest had an absorbing charm for two young listeners, in after years, and many times has the present writer dreamed herself into that young circle, playing at Indians on the island at Water House, or wandering through the twilight of the hornbeams in the Forest in search of adventure. ${ }^{9}$

6. For an account of Morris's Marlborough days, see MacCarthy, William Morris, 41-48. Succeeding citations to MacCarthy are to this volume unless noted otherwise.

7. Kelvin, Letters, 2:227-28.

8. May Morris, William Morris: Artist, Writer, Socialist, 2:612 (hereafter AWS). Most of Morris's relatively few recollections of his family life were bleaker: punishments for falling, misspelling, and covering himself with tiger lily pollen, as well as assorted rebukes by his older sister Henrietta.

9. May Morris, ed., CW, 1:ix. 
More tellingly, she recalled elsewhere her father's remarks that "children bring each other up"; that his eldest sister Emma "was a gentle nature and specially fond of him," and that "Hennie [Henrietta]" was "more given to 'ruling" "10 (Henrietta was displeased, for example, when he refused to attend the Duke of Wellington's funeral in 1852).

As he drafted the biography, Mackail asked for comments from Morris's brother Stanley and sisters Henrietta and Emma. ${ }^{11}$ Emma, his childhood ally and favorite, remembered that she and her brother had "poured over the enthralling pages" of "The Old English Baron in the rabbit warren at Woodford, till both were wrought up to a state of mind that made them afraid to cross the park to reach home." ${ }^{12}$ Stanley could not recall expressions of unhappiness on his brother's part, but remembered that William had been familiar with Gerard's Herbal, that he "knew the names of birds" as well as plants and trees, and that the two boys had fished, boated, skated, and shot redwings and fieldfares. ${ }^{13}$ Mackail apparently did not interview the other brothers and sisters, though five other siblings were still alive and in England as he wrote. ${ }^{14}$

Arthur, for example, was a retired military officer, Edgar worked for Morris at Merton Abbey, ${ }^{15}$ (Hugh) Stanley had become a gentleman farmer and failed mining speculator, ${ }^{16}$ and (Thomas) Rendall, who briefly attended a German university before entering the army, had died in 1884 at forty-five, leaving eight children to be raised by his sister Isabella Gilmore. ${ }^{17}$ William helped select a home for his sister Henrietta after his mother died, and contributed stained-glass designs for the chapel of an Anglican nursing order established by Isabella. ${ }^{18} \mathrm{He}$ also stopped by Emma's house in Clay Cross, Derbyshire on

10. AWS, 2:613.

11. There were nine children in all: Emma and Henrietta (older), Isabella and Alice Mary (younger), and in addition to William, four younger brothers (Hugh) Stanley, (Thomas) Rendall, Arthur, and Edgar (Llewellyn).

12. J. W. Mackail, The Life of William Morris, 1:8.

13. Notebook, William Morris Gallery WMG J163, entries for 1844 and 1847.

14. Nicholas Salmon and Derek Baker, William Morris Chronology, 128.

15. Morris had tried to find work for his unemployed brother, described as one who had "no vice but never could keep money," and eventually employed him at the Firm (MacCarthy, William Morris, 434-35).

16. Charles Harvey and Jon Press, Art, Enterprise and Ethics: The Life and Work of William Morris, 41.

17. Janet Grierson, Isabella Gilmore, Sister to William Morris, 33. See also Frank C. Sharp, "Isabella Morris Gilmore." She recalled in her memoirs a semirural childhood in which she and her brothers fished in a moat stocked with pike and perch. Only a few details of Morris's later relationship with his sister, a deaconess in Southwark, seem to have been preserved.

18. This was Gilmore House, later the Rochester and Southwark Diocesan Deaconess House. Isabella Gilmore is considered a pioneer in the revival of deaconess houses in late 
his journeys to Northern England for the socialist cause, and at his death provided a $£ 100$ annuity for her in his will. ${ }^{19}$

Morris's father was a bill-broker and successful mining speculator, who at his death in 1847 at age fifty ${ }^{20}$ left $\mathfrak{£ 6 0 , 0 0 0}$ in Devon Great Consols mining shares and other securities to his widow and children. ${ }^{21}$ Morris never mentioned his father personally in print apart from a reference to him as "a city man and very 'religious"' in an 1884 letter to the Manchester Guardian, ${ }^{22}$ and Mackail's blunt remark that the paternal lineage had "a marked neurotic and gouty tendency” almost certainly echoed Morris's personal view. ${ }^{23}$ MacCarthy has suggested that Morris might have alluded to his father indirectly in an 1887 Commonweal sketch of a wealthy capitalist who, when his son criticized the emptiness of his father's workday, "wonder[ed angrily] what will happen to that boy. Suppose he should turn Socialist when he grows up!!"24

What effect the father's example and memory had is unknown, but in later life Morris expressed his view that middlemen-bankers, financial managers, and so forth-were overpaid social parasites. ${ }^{25}$ By comparison with his father's great wealth (derived from copper- and arsenic extraction), even Morris's eventually successful "Firm" would have seemed a modest undertaking, and he told W. S. Blunt that when he had sold two shares of Devon Great Consols in 1861 and 1862 to help finance Morris, Marshall, Faulkner and Co., "my relations thought me both wicked and mad." ${ }^{26}$

nineteenth-century England; see Grierson, Isabella Gilmore.

19. Dorothy Coles, "My Dearest Emma': William and Emma Morris."

20. Ibid., 48. Coles notes that "his death certificate gives the cause of death as 'Cancer or ulceration of the stomach. 2 years certified.' This implies that he must have had a long period of painful indigestion or even of bleeding from the stomach." Though it is often stated that Mr. Morris died suddenly, such an illness would surely have been apparent to his family.

21. For a discussion of the effect of his family's mining investments on Morris's later political views, see Florence Boos and Patrick O'Sullivan, "Morris's Socialism and Devon Great Consols," JWMS 20.1 (2012): 11-39.

22. MacCarthy, William Morris, 24.

23. Mackail, Life, 2:335.

24. 30 July 1887; MacCarthy, William Morris, 24. He did recall his father having taken him to visit Canterbury Cathedral when he was eight, an epiphanic sight for the young Morris (AWS, 2:615).

25. "Socialism," 23, in Florence Boos, ed., "'Socialism' and 'What We Have to Look For': Two Unpublished Lectures by William Morris," JWMS 19.1 (2010): 18-56. "Some are engaged in work which only our complicated system of compulsion and inequality, of injustices in short, makes necessary; they, as lawyers \& clergymen[,] for instance[,] are the parasites of the system: but the rest are engaged in gambling or fighting for their individual shares of the tribute which their class has compelled the working class to yield to it; they are never producing wealth[,] hard as they may work."

26. Charles Harvey and Jon Press, William Morris: Design and Enterprise in Victorian Britain, 47 . 
Almost as marked was Morris's reticence about the character and temperament of his mother, Emma Shelton Morris. During his youth she would have been preoccupied with the cares of raising nine children, and as mentioned, he rejected the "rich establishmentarian Puritanism" she shared with her husband. Morris's letters to her in later life, though dutiful and affectionate, are mostly confined to family matters and avoid mention of his serious pursuits. May Morris remembered her grandmother's "fond pride in the son who had once disappointed her by giving up the Church as a career. . . . 'Why, my dear, he might have been a Bishop now!' she exclaimed to me once with plaintive affection; but I think she was very well content with things as they were!"”27

A mark of her hopes for him was her decision to board him with a private tutor after a student rebellion exposed the chaotic conditions at Marlborough College, an expensive but genuinely beneficial arrangement that helped him "[develop] during this period ... into a very fair classical scholar" and pass the entrance examinations to Oxford. ${ }^{28}$ She also paid for his university education and urged him to complete his degree when he chafed at the institution's stultifying environment. Cormell Price recorded in his diary in September 1855 that Morris had written that he was returning to finish his university education, "though I should not have done so if it had not been for my Mother," ${ }^{29}$ and when he wrote to announce his decision to abandon the clergy and apprentice himself to an architect, he reminded her that "you said then ... that it was an evil thing to be an idle, objectless man."30

Six years later Emma Morris loaned Morris two hundred pounds toward the founding of Morris, Marshall, Faulkner and Co. in $1861^{31}$ (thus accommodating a second change in career). She also gave each of her nine children their inheritance of thirteen shares of Devon Great Consols when they came of age, thus providing them with financial and emotional independence as

27. CW, 4:xvii. Georgiana Burne-Jones remarked of Burne-Jones's first visit to Morris's home that his mother had "welcomed Edward kindly, and seeing his affection for her son would willingly have told many stories of his childhood; but at this Morris [then nineteen] chafed so much that the anecdotes had to be deferred" (Memorials of Edward Burne-Jones, $2: 87)$.

Fiona MacCarthy attributes Morris's early sense of loss in part to his mother's emotional distance, conveying "a complex knowledge of the hazards of real communication between sons and their mothers" (William Morris, 11). Still, of her nine children two were distinguished for social activism, and Emma Oldham and her husband for charitable works in his parish.

28. Mackail, Life, 1:26.

29. 28 September 1855, Kelvin, Letters, 1:23.

30. 11 November 1855 , ibid.

31. Harvey and Press, William Morris: Design and Enterprise, 47. Morris had raised $£ 400$ for the company by selling his shares. 
young adults. All these decisions, some of which were almost certainly reluctant, helped Morris pursue the active and strongly independent course of his later life.

In later life, Emma Morris may even have become less "puritanical." May recorded frequent visits to her house in Leyton (then more rural) "with the grandmother who spoilt us so outrageously and adorably,"32 and in 1889 Jane wrote of her mother-in-law, then eighty-four, that

she is the liveliest old lady possible, she walks and takes drives in an open carriage every day except in the very coldest weather, and reads and talks incessantly, she is quite happy and I really think she expects to live another twenty years at least. ${ }^{33}$

Emma Morris might have led a different life had she not been burdened by the care of a large family, and when death came, Morris recorded his qualified gratitude at her funeral:

Tuesday I went to bury my mother, a pleasant winter day with gleams of sun. She was laid in earth in the churchyard close by the house, a very pretty place among the great wych-elms, which, if it were of no use to her, was softening to us. Altogether my old and callous heart was touched by the absence of what had been so kind to me and fond of me. ${ }^{34}$

His remarks pay tribute to his mother's loyal and motherly virtues, but they avoid mention of any broader gifts of mind or character.

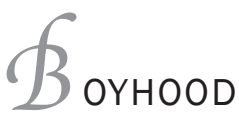

As his family's eldest son, Morris endured that notorious bourgeois privilege of a boarding-school education, initially in a local school in Walthamstow, and later, as mentioned earlier, at Marlborough College, where his father had previously secured him a place. At school in Walthamstow he had not been permitted to visit his family, or speak to them in the local church..$^{35}$ At Marl-

32. $C W, 4: x i i i$.

33. 12 February 1889, Salmon and Baker, William Morris Chronology, 213.

34. 11 December 1894, ibid., 267; Kelvin, Letters, 4:240-41.

35. AWS, 2:612. 
borough College his trips home were limited, and he had to beg his family for postage to write them.

At home and away, he found compensatory pleasures in his lifelong ability to enjoy physical aspects of his environment (evident in the remarks to Andreas Scheu quoted earlier). His father's estate in Walthamstow, for example, had included more than fifty acres of private forest and one hundred acres of farmland, and memories of his wanderings merged with recollections of early reading, folk pageants, and fresh rural food. ${ }^{36}$ Even the smaller Water House, to which the family moved on the death of the senior William Morris, had possessed a park and pond with a small island. Near the end of his life, he remarked of this "love of beauty" (natural and created) that "I have it ... naturally, for neither my father nor my mother nor any of my relations had the least notion of it." ${ }^{37}$

As for the boarding-school regime, he wrote to the Reverend William Sharmon in the late 1880 os that

my parents did as all right[-thinking] people do, shook off the responsibility of my education as soon as they could; handing me over first to nurses, then to grooms and gardeners, and then sending me to a school-a boy farm, I should say. In one way or another I learned chiefly one thing from all these-rebellion ... experience has shown me that the parents are the unfittest persons to educate a child. ${ }^{38}$

These comments, despite their wry indirection, reflect as poorly on his parents as on his schooling.

In the fall of his first year at Marlborough College, as we have seen, the family moved from Elm House to Water House, also in Walthamstow. In his first extant letter, written to Emma on November 1, he strained to imagine the physical coordinates of the new house:

I am glad to hear that you like the new house so much but you have not exactly described the situation of the house to my satisfaction. I can't under-

36. Somewhat less idyllic was a one-cell prison in Woodford he later described to his daughter Jenny: "There were stocks there on a little bit of wayside green in the middle of the village: beside them stood the cage, a small shanty some twelve foot square. . . . I remember that I used to look at these two threats of law and order with considerable terror, and decidedly preferred to walk on the opposite side of the road" (ibid., 614).

37. Wilfred Scawen Blunt, My Diaries (New York: Knopf, 1932), 229.

38. 24-30? April 1886, Kelvin, Letters, 2:546. He continues with even more dubious praise: "That was good; but, look you, if my parents had been poorer and had had more character they would have probably committed the fatal mistake of trying to educate me" (546-47). 
stand which one you mean it can't be the one that used to be Mrs. Clarke's, is it? or is it the one next to it where whenever I passed there were sure to come up to the street gate a whole legion of greyhounds, Scotch, English, and Italian, do you know the one I mean? It is not I know Mr Farquarhson's, and least of all our old house; however whatever place it is you must write and describe the place exactly. ${ }^{39}$

His grammar improved with age, but his epistolary manner was already selfeffacing but determined:

When you sent that letter with the money you said you would send me till Christmas postage stamps when I wanted them, will you be kind enough to send them about 7 I don't think I shall want any more 'till Christmas, after which time according to our agreement I shall have to get them myself.

... It is now only 7 weeks to the holidays, there I go again! Just like me! Always harping on the holidays! I am sure you might think me a great fool to be always thinking about home always but I really can't help it I don't think it is my fault for there are such a lot of things I want to do and say and see. $^{40}$

Evidently, despite the family wealth the Morris children were not indulged with an excess of disposable income. The last two sentences also expressed a boyish counterpart of a pattern that recurred in almost everything he wrote: diffidence in defense of a cause he insists is just.

The next extant letter was also to Emma:

On Friday I received your letter and I thought that it had been rather long in coming but I suppose it was just too late for the delivery on Thursday. . . . I hope very soon to get a tremendous long letter from you dear Emma but in the meantime I must say goodbye for the present with my best love to all. ${ }^{41}$

In this period he also shared Emma's interest in High Church services, and carefully described a school confirmation before closing with a slightly abashed request:

I want just to ask you something. James before I went gave me a rabbit and I asked him to sell the young ones for me which he said he would do for me.

39. 1 November 1848, Kelvin, Letters, 1:3.

40. Ibid.

41. Ibid., 1:4. 
do you think there was anything wrong in it will you write and tell me if you think it so; (you need not tell anyone of it) the reason I did it was to get a nice fishing rod. I did not like to ask Mamma to give me one and what with other things I did not think I should have enough to buy one otherwise; will you let this part of my letter be private and confidential dear Emma and again

Believe me Your most affectionate Brother. ... ${ }^{42}$

It is unclear whether "Mamma" or James (who might have benefited from the sale $^{43}$ ) was the focus of his remorse, but his modest evasion of authority was as earnest as the valedictions were sincere.

In his last extant letter from Marlborough, dated April 13, 1849, Morris's response to a performance of the school choir prefigured a lifelong attachment to 'ancient' music: ${ }^{44}$

I thought it very beautiful. The first verse was sung by the whole the second began by one treble voice till at last the base took it up again gradually getting deeper and deeper then again the treble voice again then again the base the third verse was sung entirely by base, not very loud. . . the only fault in the anthem seemed to [be] to me that it was too short. ${ }^{45}$

At Oxford he and Burne-Jones frequently sang plainsong, ${ }^{46}$ and Morris continued to enjoy ancient music throughout his life. Shortly before his death Arnold Dolmetsch brought a pair of virginals to Kelmscott House to play several sixteenth-century pieces for him, and he reportedly broke into a cry of joy at the beginning of a pavan and galliard by William Byrd. ${ }^{47}$

In his next letter, the young Morris also described a Druid Circle, and, more vividly, a "water meadow":

Perhaps you do not know what a water meadow is as there are none of them in your part of the world ... so for your edification, I will tell you what a delectable affair a water meadow is to go through; in the first place you

42. Ibid., 1:6.

43. Coles, "My Dearest Emma," 50-51. Coles is the first to see in this seemingly trivial request a scrupulous conscience toward a family employee, who might have needed the proceeds from the rabbit litter.

44. Andrew Haywood, "Morris and Early Music: The Shaw/Dolmetsch Connection."

45. Kelvin, Letters, 1:6.

46. Mackail, Life, 1:66. Mackail describes their "going to sing plain-song at the daily morning services in St. Thomas's Church."

47. Ibid., 2:334. 
must fancy a field cut through with an infinity of small streams say about four feet wide each ... the people to whom the meadow belongs can turn these streams on and off when they like and at this time of the year they are on just before they put the fields up for mowing . . . the grass being very long you cannot see the water till you are in the water and floundering in it except you are in [?] above the field ... luckily the water had not been [high] when we went through it else we should have been up to our middles in mud, however perhaps now you can imagine a water meadow. . . ${ }^{8}$

This last letter makes it clear that Morris at fourteen was affectionate, a bit insistent, and very articulate-a certain pride shone through his suggestion that "perhaps now you can imagine a water meadow." A schoolfellow remembered him as "a thick-set, strong-looking boy, with a high colour and black curly hair" (his hair was in fact dark reddish-brown), and another recalled that he was "fond of mooning and talking to himself" about "knights and fairies." ${ }^{49}$

"Mooning" or no, his stories were eagerly sought after by his dormitory captain, and he was also described as a ferocious weaver of nets, the first of many unorthodox manual crafts. He apparently managed to preserve his independence and compel respect: his schoolfellows considered him strange, and like many others, he was chafed and taunted in school, in response to which, according to unused notes for J. W. Mackail's biography, he "would rush roaring - but only half angry—with his head down \& his arms whirling wildly, at his tormentors." ${ }^{\circ}$ A schoolmate later remembered him as "goodnatured and kind, but with a fearful temper," potentially useful traits in an environment of harassment by the older boys. ${ }^{51}$

The sudden intensity of his "fearful temper[s]" and their later counterparts suggest a mixture of ordinary anxiety and what might now be diagnosed as sequelae of a mild form of neurological impairment, and Morris himself later interpreted them, with deep regret, as hereditary forerunners of the epilepsy that blighted his elder daughter's life. ${ }^{52}$ Evidence for this conjec-

48. Kelvin, Letters, 1:7. Kelvin reads this as "bog" but "high" would fit the meaning.

49. Mackail, Life, 1:17.

50. Mackail Notebooks, William Morris Gallery MS. 163, entries for 1849.

51. Coles, “My Dearest Emma," 52.

52. MacCarthy observes "a conspiracy of silence over Morris's true medical condition." She notes that Morris's "rages" were a "kind of seizure in which he partially lost consciousness," occurring when "a relatively minor disappointment and annoyance trigger[ed] an involuntary physical response out of all proportion to its cause . . Shaw echoes Dixon in his comment that these rages left Morris shaken 'as men are shaken after a fit'" (MacCarthy, William Morris, 78). 
ture may be found in the intense states of waking dreams or time-disoriented consciousness he experienced in later life. In a May 15, 1878, letter to Georgiana Burne-Jones, for example, he wrote from Verona of the pleasure of new stimuli: "I am more alive again, and really much excited at all I have seen and am seeing, though sometimes it all tumbles into a dream, and I do not know where I am." 53

When he first saw the stark beauty of Lake Garda

it suddenly broke upon me, with such beauty as I never expected to see: for a moment I really thought I had fallen asleep and was dreaming of some strange sea where everything had grown together in perfect accord with wild stories. ${ }^{54}$

He actually lost consciousness in Genoa:

My knees went limp, and down I went, thank you, and enjoyed a dream of some minute and a quarter I suppose, which seemed an afternoon of public meetings and the like: out of that I woke and found myself on the ground the centre of an admiring crowd. ${ }^{55}$

In some circumstances these syncopic states could obviously be interpreted as a lack of control, and in others as benign and even epiphanic illuminations. Such states of ekstasis appeared in his work as 'liminal' moments of suspended consciousness, and many of his protagonists in the early prose romances (such as Hugh in "Frank's Sealed Letter") experienced analogues of these states. And later in The Earthly Paradise, the eponymous hero of "Ogier the Dane," for example, reawakens into such altered states from a baffling succession of century-long trances.

Other events and attributes of Morris's youth have attracted the attention of biographers and critics. In 1850 when Morris was sixteen, his beloved older sister Emma, then twenty, married the clergyman Joseph Oldham and moved to Clay Cross, Derbyshire. ${ }^{56}$ Mackail remarked that Morris had felt

53. 15 May 1878, Kelvin, Letters, 1:486; italics mine.

54. 29 April 1878, ibid., 484.

55. 27 April 1878, ibid., 482.

56. Ibid., 53-58. Joseph Oldham became curate at Walthamstow from 1845 to 1848 and of Downe in Kent, 1848-51. He moved to Clay Cross in 1851, where he seems to have been a vigorous and dedicated High Church vicar until his death in 1888. Clay Cross was located in a mining district, and the Oldhams spent much of their income in helping to relieve the poor. Further information on Joseph Oldham's work at Clay Cross is contained in F. Dwelly's "Vicars of Clay Cross: 1851-1951" (Clay Cross, 1951). 
"deserted" at her departure, ${ }^{57}$ and Jack Lindsay, John Le Bourgeois, and others have argued that Morris sublimated this experience of 'abandonment' in his early poems..$^{58}$

The origins of Morris's sense of isolation almost certainly lay deeper. Morris was attracted throughout his life to ideals of idyllic private refuge and 'manly' public activity, and tried to reconcile them in many ways: in the quasibrotherhood of Red House; in a remarkably stoic response to his troubled marriage; and in his deep commitment to the ideals of "fellowship" exemplified in the poignant figure of John Ball. He often described the tensions of such reconciliation in erotically stylized poetic forms. But the fears and conflicts that flowed through them were part of his temperament from early childhood, along with his "tempers/seizures" and a sense of lonely insight and refuge in the welcoming realm of ideals and books. They were not created chiefly by a sublimated sense of betrayal by a kindly older sister.

The year after Emma Morris's departure Morris was liberated from Marlborough when a student uprising against school conditions erupted in the fall of 1851 (an event he later described to his interested children). ${ }^{59} \mathrm{He}$ spent the next year with several other students in Walthamstow and Devonshire, reading classical texts under the direction of the High Church clergyman, F. B. Guy, who shared his interests in painting and architecture. ${ }^{60} \mathrm{~W}$. H. Bliss, another of Guy's pupils, later recalled his unusual strength, energy at singlestick, and fondness for fishing, walking, and riding in the forest. ${ }^{61}$ Morris reportedly made no other close friendships there, and went up to Oxford (with Bliss) the following year.

\section{HE "BROTHERHOOD"}

The not-quite-nineteen-year-old Morris who left for Oxford in January 1853 was independent, endowed with fierce temperamental preferences, and devoted to certain beloved pursuits. The closest affectional bond of his early

57. William Morris Gallery, WMG MS. J163.

58. John Le Bourgeois, The Youth of William Morris, 1834-76: An Interpretation (Diss., Tulane, 1971), Art and Forbidden Fruit: Hidden Passion in the Life of William Morris, 11; and Jack Lindsay, William Morris: His Life and Work, (London: Constable, 1975; New York: Taplinger, 1979), 29-33.

59. May Morris, $C W, 1: x$.

6o. Mackail, Life, 1:25-26. According to Mackail, he accompanied Guy into Devonshire during the Long Vacation (26).

61. Ibid., 26. 


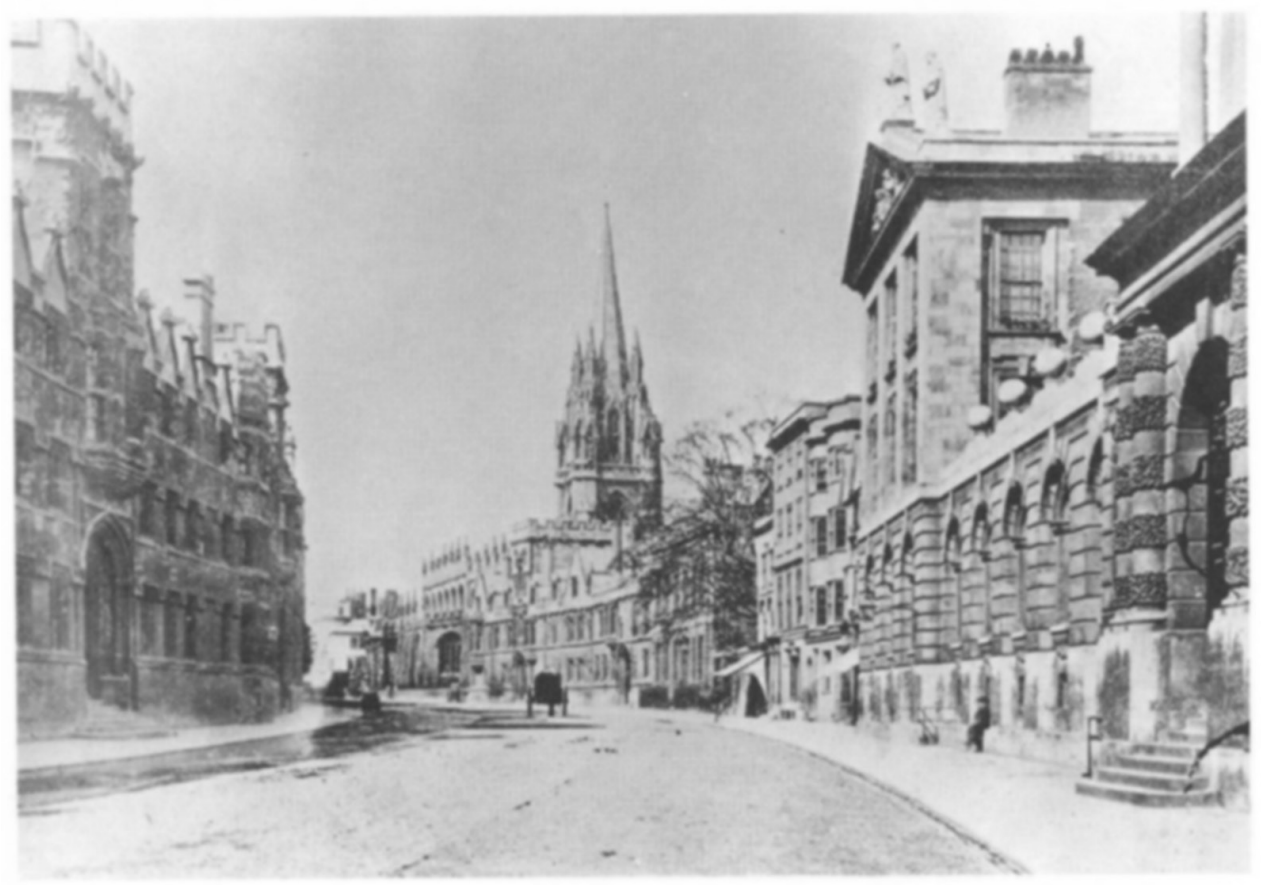

FIGURE 1. Oxford High Street 1875. Courtesy of the English Heritage Archive, Henry W. Taunt Collection.

life had been attenuated two years earlier, and he had not formed other close friendships or ties. Against this background, it is the more remarkable therefore how deeply and swiftly he formed such attachments on arrival at Oxford, and the tenacity with which he held to them in later years.

Morris's closest lifelong friends were Ned Jones (later Edward BurneJones), Charles Faulkner, Cormell Price, and Philip Webb. The first he met at a matriculation examination for Exeter College in June 1852; the second and third as an Oxford undergraduate; and the fourth in 1856 as his fellow apprentice with G. E. Street in Oxford. At Oxford Jones had introduced him to other students from Birmingham, among them Faulkner, Richard Watson Dixon, William Fulford, and (when he came up the next year) the somewhat younger Cormell Price. This 'Brotherhood' met as a group nearly every evening, and apparently had little interest in or regard for other social connections in their various colleges. 


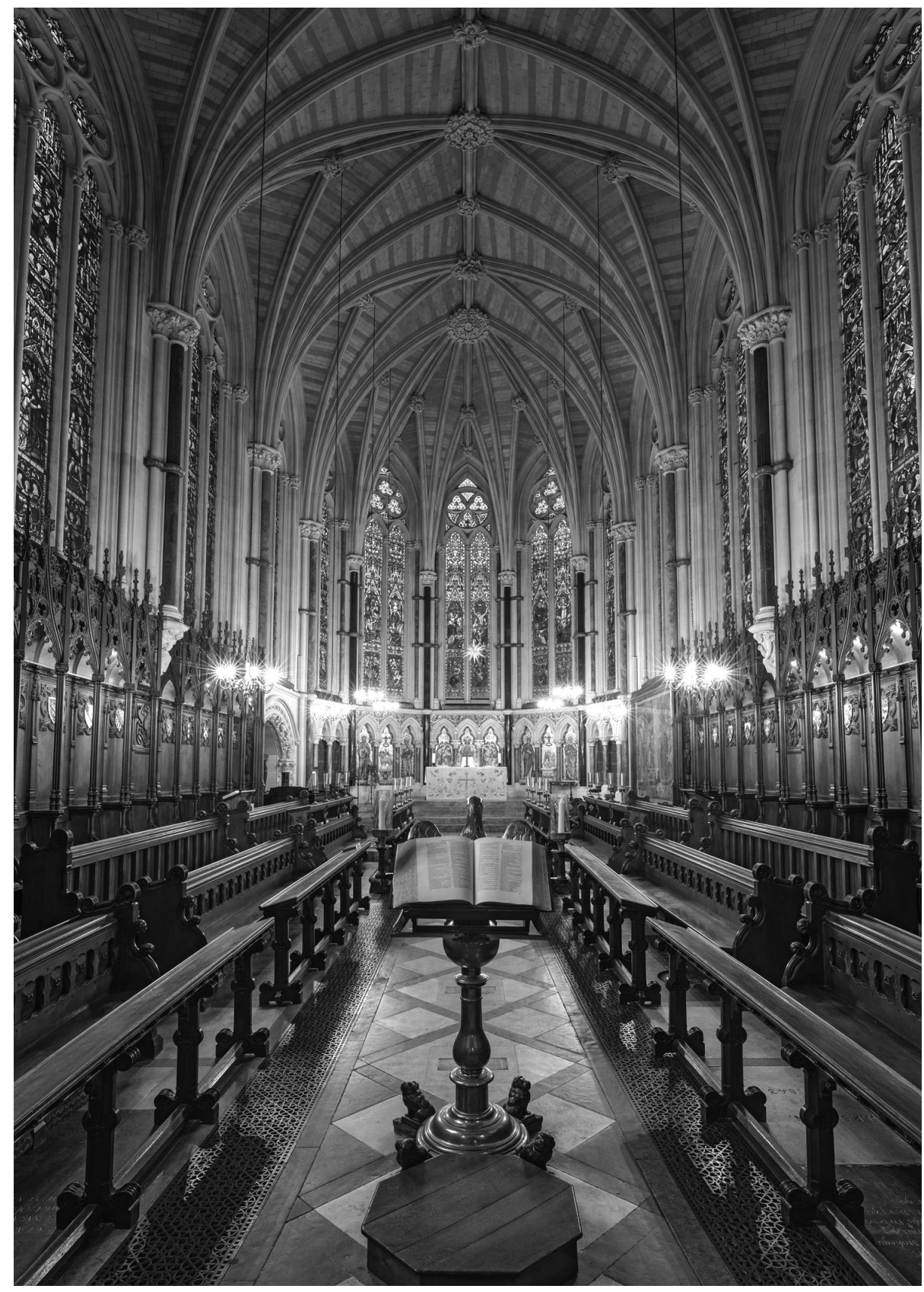

FIGURE 2. Exeter College Chapel, under construction 1854-56. Photographer, D. lliff. 


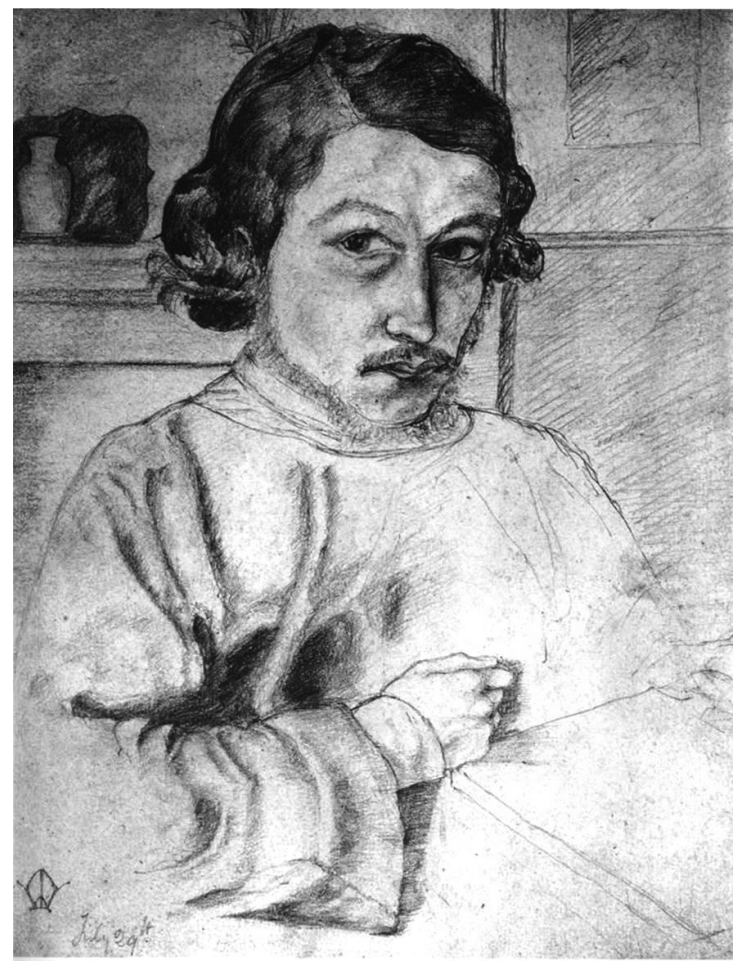

FIGURE 3. William

Morris, early selfportrait. Courtesy of the National Portrait Gallery.

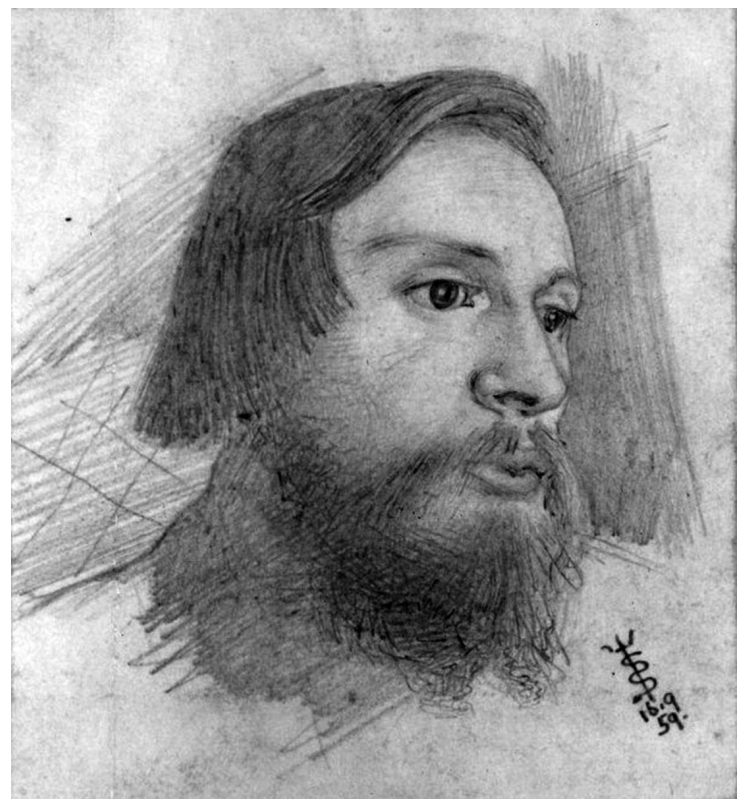

FIGURE 4. Edward

Burne-Jones, drawing by Simeon Solomon. Ashmolean Museum. 


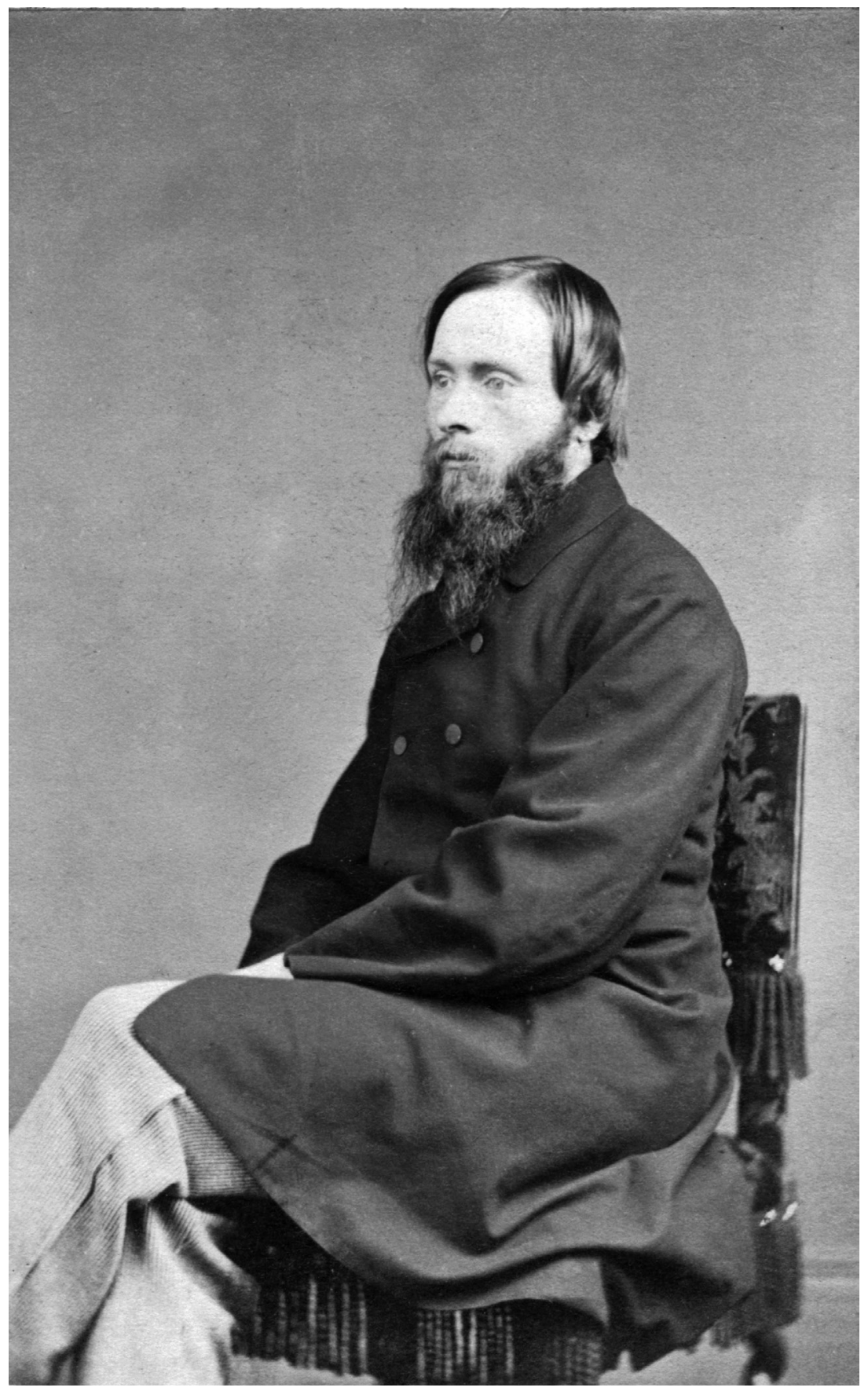

Figure 5. Edward Burne-Jones. Courtesy of the National Portrait Gallery. 

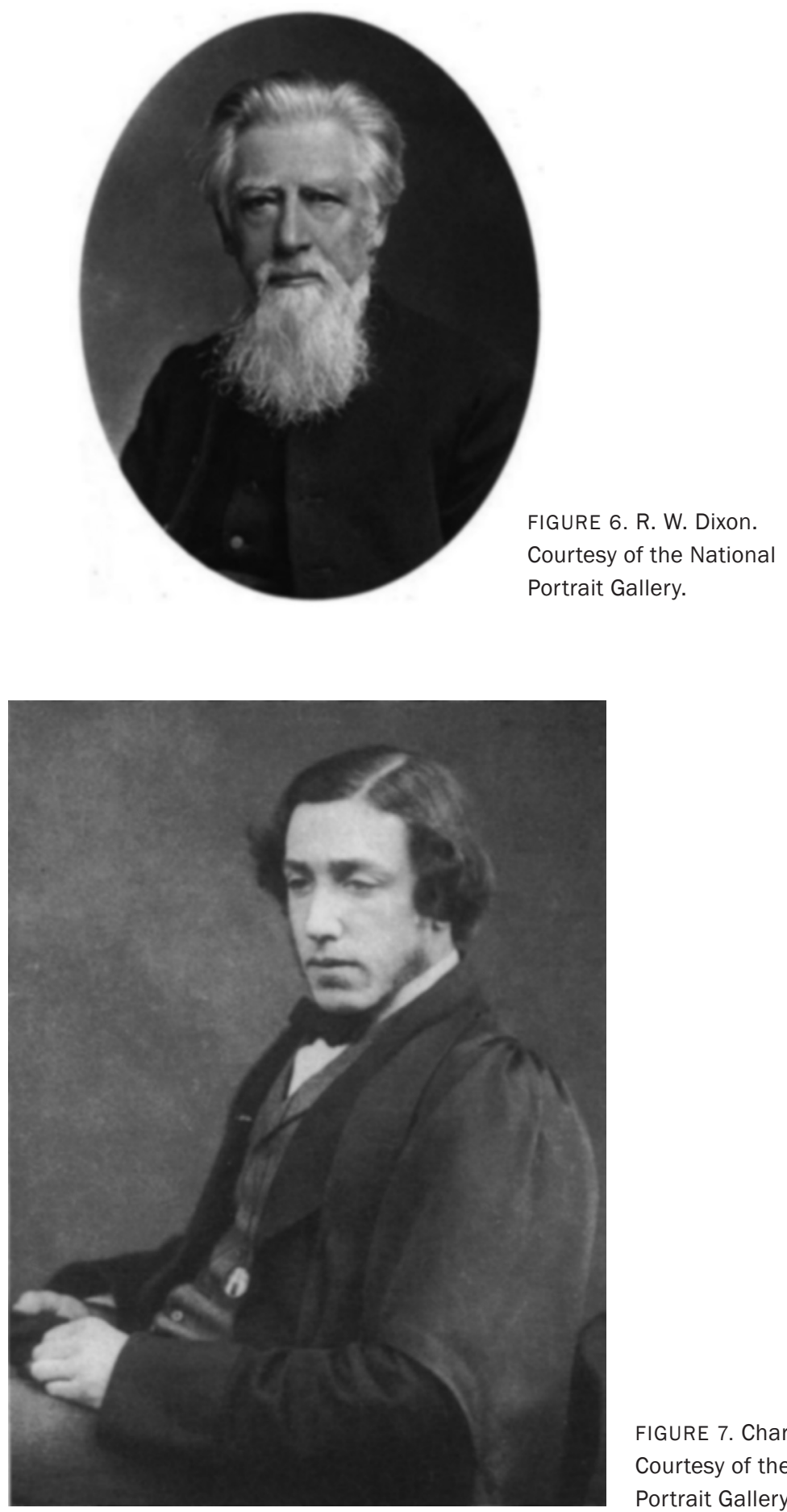

FIGURE 7. Charles Faulkner.

Courtesy of the National

Portrait Gallery. 


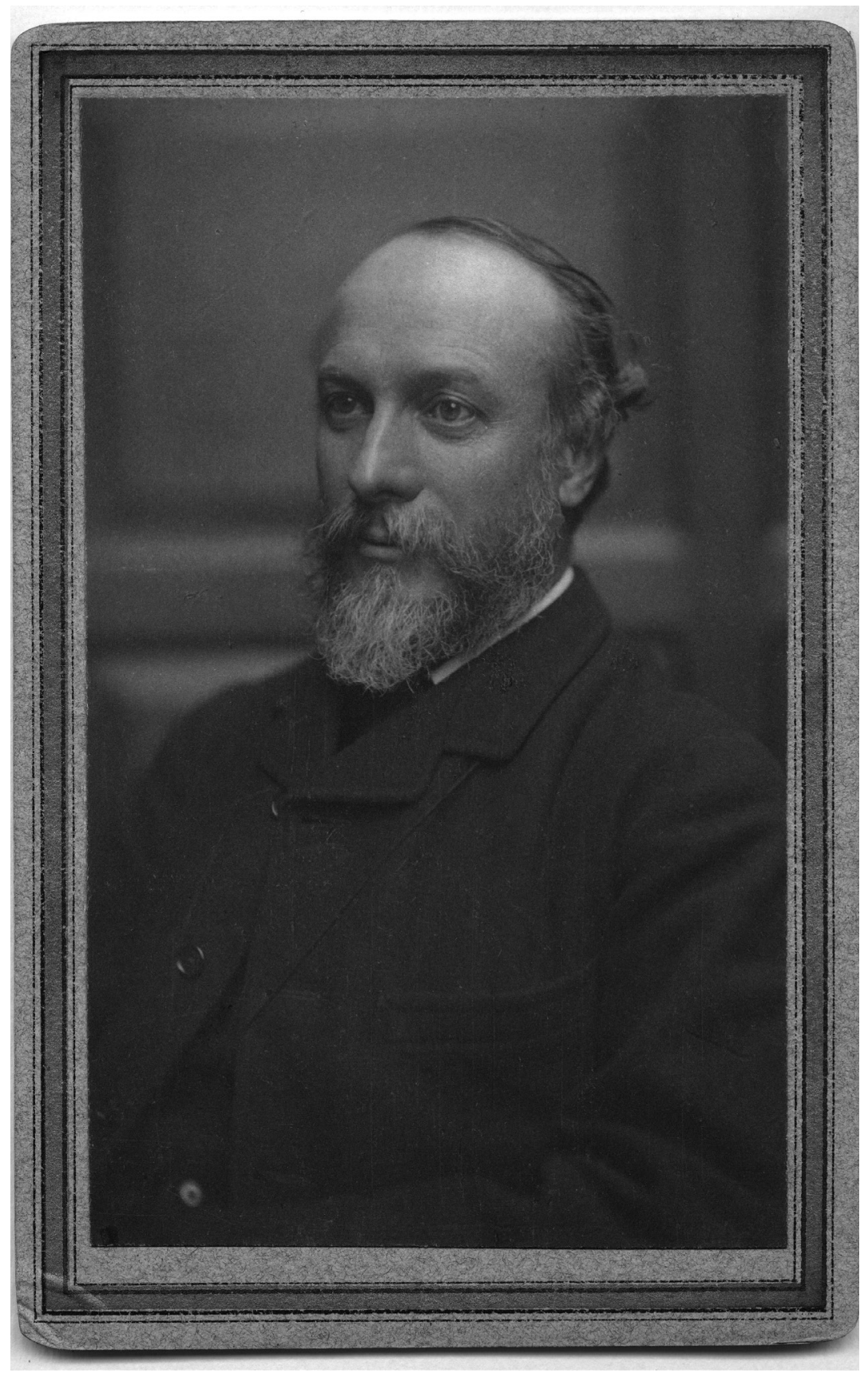

FIGURE 8. Cormell Price. Courtesy of the National Portrait Gallery. 


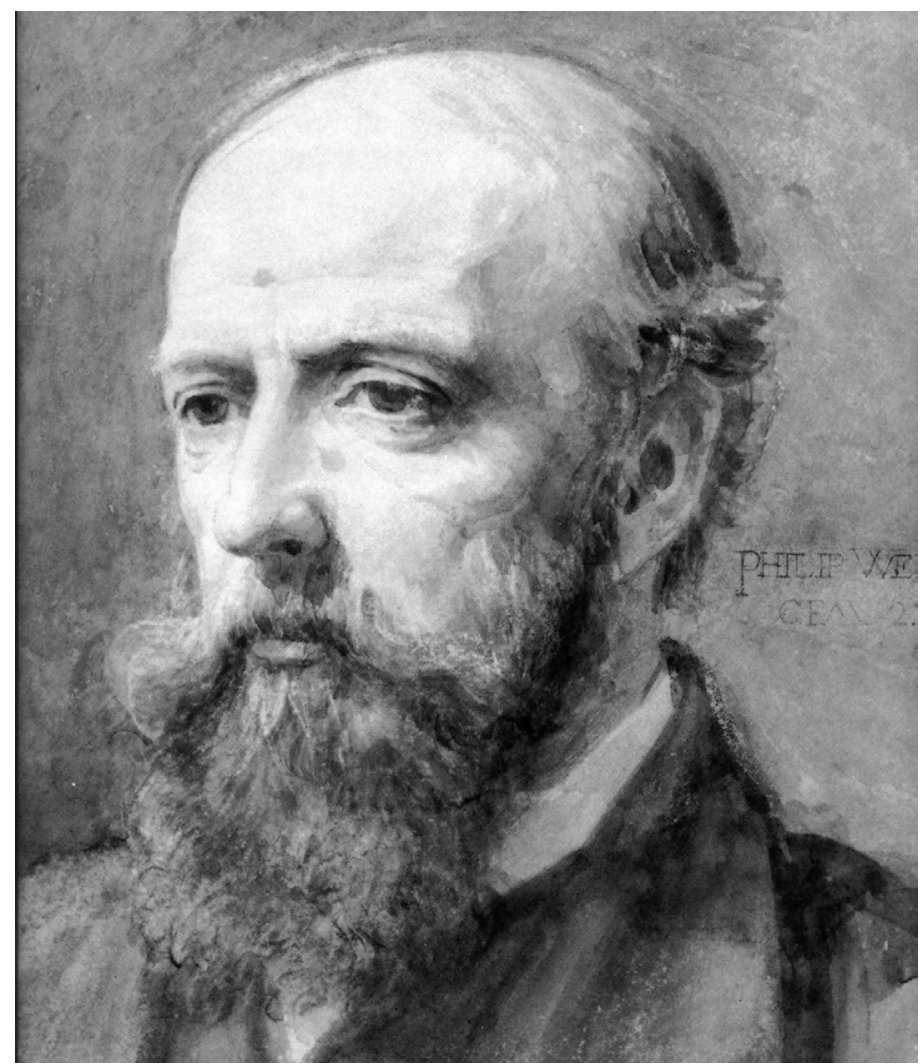

FIGURE 9. Philip Webb. Courtesy of the National Portrait Gallery.

Opportunities to choose basic life attachments on grounds of emotional and intellectual affinity are rare, and Morris, unconventional and newly detached from his family, took strong advantage of them. Later, of course, he broadened the range of his (male) friends to include people as diverse as Eiríkur Magnússon, Emery Walker, and Andreas Scheu, but he always remembered this first model of fraternal fellowship, in which friends with diverse gifts and blind spots turned to each other for spontaneous personal and intellectual sympathy.

Georgiana Burne-Jones's Memorials and Mackail's biography provide extended accounts of Morris's three years as an undergraduate at Oxford, and these, the two years that followed in Oxford and London, and his periods of greatest socialist activity were the best-documented periods of Morris's life. 


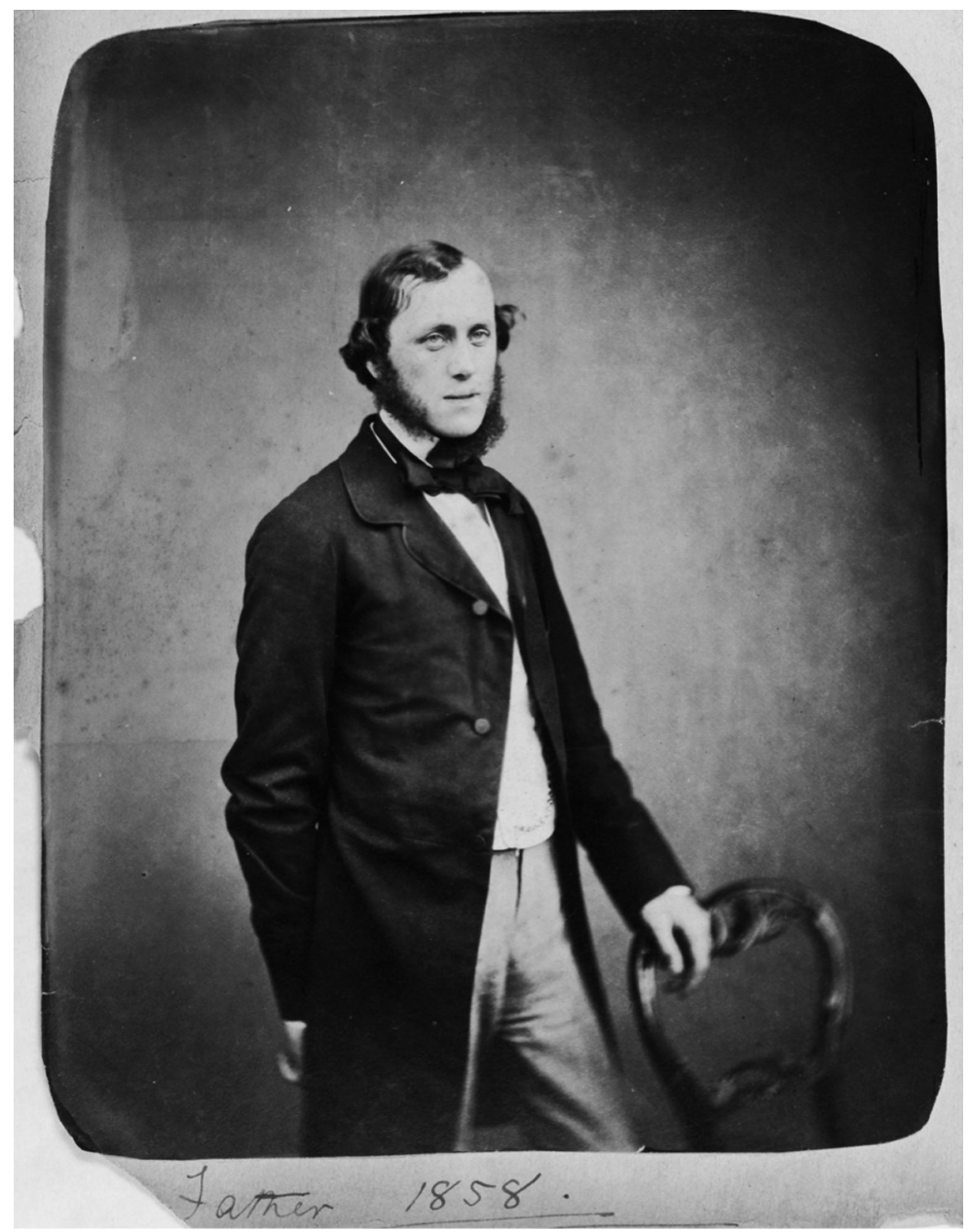

FIGURE 10. Vernon Lushington. Courtesy of the National Portrait Gallery.

Georgiana's account was strongly influenced by her respect for the ideals of her husband's youth, and Mackail's by her memories and his knowledge of Oxford and the intellectual undercurrents that flowed through it. ${ }^{62}$

62. Often Mackail quotes from what seem to be written accounts or memories provided by Edward Burne-Jones, the original of which seems not to have survived, e. g., Life, 1:100102. Since Morris died in 1896, Burne-Jones in 1898, and the Life appeared in 1899, it is possible that Burne-Jones contributed memories in the knowledge that his son-in-law intended to write a biography, and/or that Mackail interviewed him and transcribed his statements. 
Here, for example, is Mackail's description of the environment Morris and Jones encountered when they arrived:

The Oxford of 1853 ... still ... offered to its most ardent disciples, who came to it as to some miraculous place, full of youthful enthusiasm, ... the stony welcome that Gibbon had found at Magdalen, that Shelley had found at University, in the days of the ancient order. ${ }^{63}$

The young Morris who left Oxford without ostensible academic distinction was such an "ardent disciple." Eagerly and systematically, he studied: religious music and architecture; church decoration; illuminated manuscripts; brass rubbings; woodcuts; later medieval and contemporary painting; older and contemporary poetry and contemporary fiction; religious and secular chronicles and histories; and contemporary theological debates and current social thought.

He also exercised daily at singlestick, took extensive walks, rode, fished, visited northern England several times, and traveled twice to France. All of these activities were shared with other members of the small 'brotherhood' mentioned earlier. In what follows, I will try to examine relevant aspects of Morris's friendships with three of the 'brothers' to whom he was closest in this period-Edward Burne-Jones, Charles Faulkner, and Cormell Price.

\section{dward Burne-Jones}

Edward Burne-Jones's personal attachment to Morris emerges again and again in Georgiana Burne-Jones's Memorials:

Northing ever interrupted the intimacy with Morris; that friendship was like one of the forces of nature... . To none but trusted friends did [Edward] allow himself a joke about Morris: I shall never forget his grave reproach to me for having allowed the name "Topsy" to escape before a comparative stranger. ${ }^{64}$

The fact that so much of Morris's life has been filtered through the Burne-Joneses can cause unintended assimilation of Morris's views and habits to those of his friend, and the erasure of part of the record-e. g., the relatively slight attention given to Charles Faulkner, R. W. Dixon, and Philip Webb in the Life, as well as the near-erasure of William Fulford, whose brief engagement to Georgiana's sister Alice (later the mother of Rudyard Kipling) had been broken off.

63. Mackail, Life, 1:31.

64. Burne-Jones, Memorials, 2:5. 
The two families got together on a near-daily basis, and much of Morris's artistic lifework enjoyed Burne-Jones's collaboration: his decorative work at the Firm, of course; but also his engagement in the Society for the Protection of Ancient Buildings and the designs for the Kelmscott Press. Mackail, BurneJones's son-in-law, described the bond, with only some exaggeration, as

the great controlling friendship of [Morris's] life. Jones was from the unlovely surroundings of middle-class life in Birmingham, but with the same tastes, the same enthusiasms, the same ideals .... They ran together like two drops of mercury; and for more than forty years ... there was never a day's intermission in their comradeship. ${ }^{65}$

Georgiana Burne-Jones began her account of the meeting of Morris and Jones quite strikingly with an epigraph from Proverbs, "As in water face answereth to face, so the heart of man to man," and she described Edward's response as follows: "In his disappointment [at Oxford] he turned around, seeking his way in unlooked for loneliness of spirit, and there, shoulder to shoulder, stood his life's companion.”66

Richard Watson Dixon, a poet and another member of the group, later wrote vivid and respectful memories of his Oxford friends that contrast sadly with his near-absence from their own recollections. ${ }^{67}$ For example, Dixon recalled a scene in which Jones

said to me and Morris that he knew the time when he felt his heart burst into a blossom of love to his friends and all the men around him. I have often thought of the earnest and excited manner in which he said this. ${ }^{68}$

Dixon described Morris as follows:

I remember Faulkner remarking to me, "How Morris seems to know things, doesn't he?" And then it struck me that it was so. I observed how decisive he was: how accurate, without any effort of formality: what an extraordinary power of observation must be at the back of his casual or incidental remarks, and how many things he knew that were quite out of our way; as, e. g. architecture. Burne-Jones, I think ... recognized his intellect from the

65. Mackail, William Morris and His Circle, 6-7. Fiona MacCarthy's The Last Pre-Raphaelite: Edward Burne-Jones and the Victorian Imagination provides new details of Burne-Jones's Birmingham life (1-25).

66. Burne-Jones, Memorials, 1:71.

67. Ibid., 86.

68. Ibid., 71 . 
first. He said once . . that Morris displayed extraordinary logical power in lecture; and might have gained eminence in mental science, if he had chosen. $^{69}$

Burne-Jones himself characterized Morris as follows:

From the first I knew how different he was from all the men I had ever met. He talked with vehemence, and sometimes with violence. I never knew him as languid or tired. . . . his hair was dark brown and very thick, his nose straight, his eyes hazel-coloured, his mouth exceedingly delicate and beautiful. $^{7^{\circ}}$

Cormell Price's younger sister shyly admired Ned Jones, whose visit to Birmingham she recorded in September 1854: "Jones came to tea. He is the most clever and nicest fellow I ever knew. He says he thinks Fulford will be a 'star' and is sure Morris will be." ${ }^{71}$

Dixon later remembered Jones's extravagant response to Morris's first poems (and invention of the nickname "Topsy," ambiguously shorted to “Top"), in late 1854:

As soon as [Cormell Price and Dixon] entered the room, Burne-Jones exclaimed wildly, "He's a big poet." "Who is?" asked we. "Why, Topsy"-the name which he had given him. ${ }^{72}$

Edward advised his cousin Maria Choyce in the same hero-worshipping vein in late 1855:

Watch carefully all that Morris writes. You will find one of the very purest and most beautiful minds on earth breathing through all he touches. Sometimes I even regret that he is my friend, for I am open to the charge of partiality by praising him so, and if he were a stranger I know I should detect him in a heap of others' writings, and watch for something very great from him, as I do now. Fulford . . . does not write so poetically nor beautifully, or rather pictorially, as Morris. ${ }^{73}$

69. Dixon, "Memoir of Morris by Richard Watson Dixon," ed. Boos, 20.

70. Mackail, Life, 1:35.

71. Burne-Jones, Memorials, 1:108.

72. Dixon, "Memoir," 21.

73. Burne-Jones, Memorials, 1:123. For a latter-day evaluation of William Fulford, see Roger Simpson, "In Defence of William Fulford: A Minor Pre-Raphaelite Poet" and "William 
Poor Fulford. His "star" had clearly paled since the tea of the preceding year. Jones wrote his longest contemporary description of Morris in 1854, to Cormell Price, then still at Birmingham:

Morris has a deal of my time. He is one of the cleverest fellows I know, and to me far more congenial in his thoughts and likings than anyone it has been my good fortune to meet with-his taste and criticism in Art and Aesthetics generally I should any day infinitely prefer to Fulford's, who you know was my old ideal in such subjects. He is full of enthusiasm for things holy and beautiful and true, and, what is rarest, of the most exquisite perception and judgment in them. For myself, he has tinged my whole inner being with the beauty of his own, and I know not a single gift for which I owe such gratitude to Heaven as his friendship. If it were not for his boisterous mad outbursts and freaks, which break the romance he sheds around him — at least to me-he would be a perfect hero.

How I am grinding you, poor fellow! Well, briefly, come and see him and hear him, not in the smoke room or in disputations (the smoke room of intellects) but by the riverside and on the highways, as I alone have seen and heard him. ${ }^{74}$

Jones's effusive idealization of Morris blended aspects of Friedrich de la Motte-Fouqué, Charles Kingsley, and Ruskin with the rhapsodic closing echo of John the Baptist's praise of Christ. Burne-Jones was given to verbal extravagance and other forms of intense attraction throughout his lifetime, but it seems clear that his admiration for the twenty-one-year-old Morris was about as unqualified as it could be.

More straightforwardly, Ned and "Top" shared complementary intellectual and emotional needs. Like Morris, Edward Jones was a half-orphan. His father was perhaps more sympathetic to Ned's aspirations than Morris's mother was to his, but he was unable to share his son's mental life or appreciation of art. Burne-Jones later reported in his characteristically hyperbolic fashion that "art was always a great bewilderment to him, and he couldn't have learned in a thousand years to discuss one thing about it." 75 Georgiana Burne-Jones, for her part, wrote that "there is little record left of his home life years. ... Both he and his father must have been infi-

Fulford: An Arthurian Reclaimed." Cf. note 62 for Fulford's abortive engagement to Alice Macdonald. Fulford later lived in London and continued to publish poetry.

74. Burne-Jones, Memorials, 1:95-96.

75. MacCarthy, The Last Pre-Raphaelite, 5. 
nitely lonely at heart in spite of the love that was between them..76 ${ }^{36}$ Morris's presence filled a void; and Burne-Jones's attachment, warmth, and obvious admiration brought greater happiness to the previously rather isolated Morris.

Finally, Burne-Jones also claimed to have enlisted some measure of support from Morris for his then most cherished aim, the formation of a religious as well as artistic "brotherhood," originally conceived on the model of a Roman Catholic celibate order. In May 1853, Ned wrote to Cormell that

I have set my heart on our founding a Brotherhood. Learn Sir Galahad by heart. He is to be the patron of our Order. I have enlisted one in the project up here, heart and soul. You shall have a copy of the canons some day.

(Signed) General of the Order of Sir Galahad ${ }^{77}$

Not surprisingly, this notion evolved into the more practicable ideal of a communal society of artists and their families, and in this form it was Morris who may eventually have taken the project more seriously. Throughout their lives, the Morrises and Burne-Joneses visited constantly. When it proved impossible for Ned and Georgiana to join William and Jane Morris at Red House, Morris wrote Edward in 1865: "As to our palace of art, I confess your letter was a blow to me at first, . . . in short I cried, but I have got over it now; of course I see it from your point of view but I like the idea of not giving it up for good even if it is delusive." ${ }^{78}$ The evolving ideal had already found two concrete realizations: publication of the Oxford and Cambridge Magazine (originally to have been called The Brotherhood) in 1856, and establishment of the firm of Morris, Marshall, Faulkner and Co. in 1861, and it would find another in collaboration in the Kelmscott Press editions in the 1890 s.

Aside from emotional needs, other traits clearly brought the two friends together and sustained the bond through later strains. The Ned Jones who later became Edward Burne-Jones was already an accomplished painter of legendary and mythological subjects, but he was also a multiply gifted, even brilliant young man. Effusions aside, his letters from Oxford show wit, tact, real erudition in literature, art, and theology, and a graceful and flex-

76. Burne-Jones, Memorials, 1:62.

77. Ibid., 77. Georgiana's account necessarily emphasizes the ideals of youth, since, as The Last Pre-Raphaelite details, much of Burne-Jones's emotional life during the 1860 s through the ' 90 s centered on his many emotional and other relationships with women.

78. Mackail, Life, 164. A slightly different version appears in Kelvin, Letters, 1:38; Kelvin's version omits the clause "of course I see it from your point of view but I like the idea of not giving it up for good even if it is delusive." MacCarthy offers some reasons why for Burne-Jones the move would have limited his career (The Last Pre-Raphaelite, 172). 
ible prose style evincing an unusual mixture of effervescence and staying power. ${ }^{79}$

He also supported enthusiastically the initiation of the Oxford and Cambridge Magazine, and wrote his cousin in 1855 that "[we] have such a deal to tell people ... so many fights to wage and opposition to encounter that our spirits are quite rising with the emergency." ${ }^{\prime \prime}$ In the event, he contributed to the Magazine a pair of vigorous defenses of Thackeray's The Newcomes and volume 3 of Ruskin's Modern Painters, with two stories ("A Story of the North" and "The Cousins"). The brutal street scene and morbid dreams under stress of "The Cousins" resembled passages in the contributions of Morris and R. W. Dixon, but its plot was livelier and more coherent than that of most of the Magazine's other tales. ${ }^{81}$ Georgiana loyally wrote in the Memorials that

the literary power which [Burne-Jones] disclaimed was proved at Oxford by the frequent "posting" of his name on the gate of his College for English Essays and was shewn always in private correspondence. [But a]fter he became a painter he seemed to feel a kind of jealousy at the employment of any other means of expression than painting, and deliberately curbed the use of words in public, so that nothing would have induced him to make a speech or write an article. ${ }^{82}$

There may be some truth to this. Jones's several letters from this period to Cormell Price were preoccupied at least as much with literature as with art, and they include many comments on his reading in 1853-54-which included Tennyson, Ruskin, Edward Allan Poe, and Alexander Smith. When Price came up to Oxford, of course, the letters ceased, so we do not know his reactions to works they read together with Morris and others of the group in subsequent years-Chaucer, Malory, Kingsley's novels, Carlyle's French Revolution. The most lavish praise in his letters to Price is reserved for Tennyson (who, as we know from Dixon's "Memoir" and the Oxford and Cambridge Magazine, was Fulford's revered model):

79. For examples, see Burne-Jones, Memorials, vol. 1, chap. 5-7.

8o. MacCarthy, The Last Pre-Raphaelite, 53.

81. R. W. Dixon's “The Rivals" appeared with Burne-Jones's “The Cousins" and Morris's "The Story of the Unknown Church" in the January issue, and Burne-Jones's "A Story of the North" appeared in February, along with Morris's essay "The Churches of North France" and "The Two Partings," by William Fulford.

82. Burne-Jones, Memorials, 1:124. MacCarthy recounts that he later declined the presidency of the Fine Art Society in Birmingham, observing that "the difficulty would be the lecture, a thing as you know so utterly out of my way, . . . all my habits of labour for many years now have been carrying me further and further from the possibility of readily expressing myself by words" (Last Pre-Raphaelite, 293). 
When I take up the works of any other poet, save Shakespeare only, I seem to have fallen from the only guide worth following far into dreamland. There are some passages here and there so strangely accordant to that unutterable feeling which comes on one like a seizure at certain times, and which Schlegel writes of under the term "Sighing after the infinite," that it is sometimes an inexpressible relief to know and be able to utter them aloud, as if the poet had, in an inspiration, hit upon some Runic words to give voice and form to what were otherwise painfully ineffable. Of these I think one song in the Princess is remarkable. "Tears, idle tears, I know not what they mean," is of this kind. In some hot dreamy afternoons I have thought upon it for hours, until I have been exquisitely miserable. Our old favourite, the "Bugle song," is another, and incidental passages over all the poems are of the same strange nature. ${ }^{83}$

There is something in Burne-Jones's breathless appreciation and "dreamland" that is not unlike the caricature critics have often made of Morris's figure of the "idle singer" Morris himself was more laconic about Tennyson's poetry; Dixon remembered his criticism of the latter's Galahad as "rather a mild youth." ${ }^{84}$

Other shared tastes are recorded in a list of books that "the Set" had especially admired, made by Burne-Jones after Morris's death. This list included Charlotte Yonge's The Heir of Redclyffe (1853); all Friedrich De La Motte Fouqués books, especially Sintram; Dickens; Kingsley (Alton Locke and Hypatia); Ruskin; Carlyle "toward the last"; ${ }^{85}$ and two stories in Household Words, "Colonel Quagg's Conversion" and "Alice and the Angel." 86 The latter-in which an aspiring artist paints his lovely but initially aloof neighbor-may have helped inspire more than one plot in the Oxford and Cambridge Magazine.

In Kingsley's Yeast (1851)-a bildungsroman and "challenge to wealthy young men" that was absent from the list, but read by Morris, Burne-Jones, and their friends- "Lancelot Smith" rejects his beloved's suggestion that he seek solace in religious faith and instead devotes himself to an active life of writing, painting, and social service, a plot that "articulated," in the words of Harvey and Press, "all the difficulties of Morris's personal situation."

83. Burne-Jones, Memorials, 1:76-77.

84. Dixon, "Memoir," 20.

85. Since he was referring to the period 1853-56, Past and Present is most likely meant.

86. Burne-Jones, Memorials, 1:142. "Colonel Quagg's Conversion," by George Augustus Sala (1855), is a comic tale in which the "colonel," noted for waylaying and beating members of a religious sect, is bested by one of those he attacks and forced to undergo "conversion" to a better frame of mind. "Alice and the Angel" (1853-54) was by William Moy Thomas.

87. Harvey and Press, Design and Enterprise, 27. 
Similar motifs of quest and self-sacrifice appeared in Friedrich de la Motte-Fouqués Sintram and His Companions and the Brotherhood's favorite novel, Charlotte M. Yonge's The Heir of Redclyffe (1853), which Mackail described as a

book which exercised an extraordinary fascination over the whole of the group, and in which much of the spiritual history of those years may be found prefigured .... The young hero of the novel, with his overstrained conscientiousness, his chivalrous courtesy, his intense earnestness, his eagerness for all such social reforms as might be effected from above downwards, his high-strung notions of love, friendship, and honor, his premature gravity, his almost deliquescent piety, was adopted by them as a pattern for actual life: and more strongly perhaps by Morris than by the rest, from his own greater wealth and more aristocratic temper. ${ }^{88}$

Yonge's primary theme was the need to modulate Byronic intensity and melancholy in a life of rectitude and struggle for the good of others, and BurneJones and Morris might have found in it a number of parallels. Morris, like Yonge's hero "Sir Guy," endured Oxonian philistinism for the friendships he made, and his ties to his family were similarly attenuated, in his case by boarding school and temperamental differences. Like Morris, Sir Guy was wealthy, bright, altruistically inclined, unimpressed by Oxford, averse to stilted social formalities, and an ardent admirer of cathedrals and natural beauty as well as Sintram, Thalaba, and the Morte d'Arthur. Yonge's protagonist is moreover compared throughout to Sir Galahad, Burne-Jones's youthful "patron," and later the subject of Morris's "Sir Galahad: A Christmas Mystery."

As for intensity, Burne-Jones's recollection of a visit to the Godstow ruins and burial place of Fair Rosamond near Oxford ${ }^{89}$ in 1854 might have graced an undiscovered letter of Morris:

The day has gone down magnificently; all by the river's side I came back in a delirium of joy, the land was so enchanted with bright colours, blue and purple in the sky, shot over with a dust of golden shower, and in the water, a mirror'd counterpart, ruffled by a light west wind-and in my mind pictures of the old days, the abbey, and long processions of the faithful, banners

88. Mackail, Life, 1:41.

89. Two and a half miles northwest of Oxford city center, Godstow was the site of a Benedictine convent and abbey church; after Henry II's mistress Rosamund Clifford was buried there, he donated money for building the abbey. 
of the cross, copes and crosiers, gay knights and ladies by the river banks, hawking-parties and all the pageantry of the golden age..$^{90}$

In the middle of the passage, however, something vulnerable, neurasthenic, and mystical supervened:

It made me feel so wild and mad I had to throw stones into the water to break the dream. I never remember having such an unutterable ecstasy, it was quite painful with intensity, as if my forehead would burst. I get frightened of indulging now in dreams, so vivid that they seem recollections rather than imaginations, but they seldom last more than half-an-hour; and the sound of earthly bells in the distance, and presently the wreathing of steam upon the trees where the railway runs, called me back to the years I cannot convince myself of living in..$^{91}$

Morris's heroes sometimes experience such dislocated states, and as we have seen, he himself recorded moments of ecstatic intensity and great joy in the presence of beautiful objects-medieval illuminated manuscripts, the cathedral at Rouen, the streets and buildings of Oxford, even Canterbury Cathedral. But his responses did not throb oppressively, make him "frightened," or bar return to the outer world.

Morris's 1855 letters to Cormell Price, for example, describe comparably intense responses to the landscapes of northern France. He too was almost overwhelmed by the beauty of what he saw-as he had been at fourteen by the epiphanic water meadow-but he retained an ability to detach himself from his epiphanies and enjoy what he beheld, as when Fulford described his gazing on the church at Amiens "with calm joy."

He and Burne-Jones also shared an ability to articulate intensity in ways that impressed others, as Georgiana remembered decades later of her young husband:

I believe there was in fact an early maturity about him.... as he talked and listened, not only his eyes but his whole face seemed lit up from within... . He was easily stirred, and then his speech was as swift and clear as possible, yet well ordered and going straight to the mark. He had a beautiful voice.93

90. Burne-Jones, Memorials, 1:98.

91. Ibid., 98-99.

92. Ibid., 113; Salmon and Baker, William Morris Chronology, 11.

93. Burne-Jones, Memorials, 1:55-56. 
They also shared-with Faulkner and others-a number of homelier traits. Both loved certain forms of humor, for example, some parodic and some 'practical', in great bouts and gusts. "Edward," wrote one of Price's sisters, "sometimes ... would laugh till he slid down from his chair to the floor and rolled there, holding himself together." 94

As we have seen, Morris's energies at times exploded in sudden alarming irritability. But his empathy, unassuming vitality, and hatred of entrapment may also have appealed to the more melancholy Burne-Jones, who quietly struggled with physical debility much of his life. Ned Jones was tall and gaunt, with a high forehead and deep-set eyes-impressive to look at, but apparently rather frail: "His health remained always just short of strength, and fatigue followed every exertion: I have heard him say that he hardly knew what it was not to be tired."95 For a "frail" man, Burne-Jones completed an enormous life work, and it may be that his "fatigue" had psychological as well as physical origins. In any case, Top's likely response to such problems may have endeared him to Ned the more. Morris's earliest writings show sympathetic concern for physical weakness. He also chose a wife who was frail and perhaps depressive, and worried attentively for many years about her health and that of Jenny, their older daughter. It may well be that Morris's attitude toward Burne-Jones was similarly protective. In an untitled 1872 manuscript published in 1982 as The Novel on Blue Paper, ${ }^{96}$ Morris described the efforts of a character who strongly resembled Burne-Jones in temperament and appearance to overcome sickness and fatigue, and during their period at Oxford he seems to have encouraged his friend to exercise at singlestick and join in expeditions to nearby sites of interest. ${ }^{97}$

Burne-Jones later became a noted painter while Morris was still relatively unknown, but from the beginning their work was deeply collaborative. Not only Burne-Jones's illustrations but many of his drawings and paintings sustain subtle thematic analogues with his friend's poetic narratives. Many of Burne-Jones's later artworks-his several paintings of Psyche and Venus, for example, and the sequences on Pygmalion and Perseus and Andromeda-derive from motifs first conceived in the 1860 s, or planned during the late 1860 s for a projected edition of an illustrated Earthly Paradise..$^{98}$ Among

94. Ibid., 69.

95. Ibid., 62.

96. The Novel on Blue Paper, ed. Penelope Fitzgerald (London: Journeyman, 1982). The frail brother is named Arthur (as is Tom Brown's frail friend in Thomas Hughes's 1857 Tom Brown's School Days).

97. Mary Lago, ed., Burne-Jones Talking. His Conversations, 1895-1898 (Columbia: University of Missouri Press, 1981), 94; Burne-Jones, Memorials, 1:80.

98. Joseph Dunlap, The Book That Never Was, 9. 
other parallels, early drawings of Lancelot, Guenevere, and Galahad invite comparison with Morris's Malorian poems in The Defence; "King Cophetua and the Beggar Maid" embodies one of Morris's favorite early motifs; "The Wine of Circe" depicts the Circe episode of The Life and Death of Jason; Burne-Jones's drawings of the Orpheus legend closely parallel Morris's version of "The Story of Orpheus and Eurydice"; and "Love Leading the Pilgrim" illustrates the central confrontation of Morris's Love Is Enough. ${ }^{99}$ And, finally, Burne-Jones's work for the Kelmscott Press included designs for $A$ Dream of John Ball, The Life and Death of Jason, Love Is Enough, The Wood Beyond the World, and Sigurd the Volsung.

Life is complex and diffuse. Morris quietly sympathized with Georgiana when the former prophet of celibacy furtively philandered in the late $1860{ }^{100}$ and he was never able to bring Ned toward Socialism, unlike Faulkner, Webb, and, to some extent, Georgiana herself. In a rupture glozed over in the Memorials, Ned felt an active hostility toward Morris's political activities, regretting his friend's expenditure of energy and disliking the latter's new companions: "I wish he could be out of it all and busy only for the things he used to be busy about." ${ }^{101}$ None of Morris's extant letters extravagantly praise BurneJones in the manner of Burne-Jones's descriptions of him, quoted above, but he often asserted that Ned was the greatest painter of his generation, and the two friends' original love of art, temperamental affinity, complementary aspirations, and mutual respect for each other's gifts went a long way. More: they created for a time a kind of mutual catalysis rare in the history of English literature and art. Ned once remarked to Georgiana that "the things that in thought are most to me, most dear and necessary, are dear and necessary to no one except Morris only."102 Whether this was intended to exclude his listener, one cannot know. In any case, after Morris's death he told his studio assistant that

[Morris] couldn't bear anything in the nature of a fragment-must have it all. It was part of that splendid sternness that was in him-was one of his

99. Burne-Jones, Memorials, 2:5. Among sources that discuss the artistic relationship between the two men, see Lesley Baker, "The Earthly Paradise of Morris and Burne-Jones," and Caroline Arscott, William Morris and Edward Burne-Jones: Interlacings. Arscott argues that themes of bodily pain, desire, and appetite are common to the works of both.

100. In The Last Pre-Raphaelite MacCarthy documents his continued relationship with Maria Zambaco and his several romantic attachments to other women, among them May Gaskell and Frances Horner, and his sense of desertion at the marriages of several young women friends.

101. MacCarthy, William Morris, 481; The Last Pre-Raphaelite, 344-50, 384, 391-92, 429.

102. Burne-Jones, Memorials, 2:284. 
ways - he would do it. ... I suppose if he'd painted he would never have hidden things with darkness. That was Top, so clear. That was Top, so out in the sunlight. Never wanted to snatch at anything. ${ }^{103}$

The accomplished painter who thought his own greatest work was "The Sleep of Arthur in Avalon" remarked sadly of Morris's 1896 burial in Kelmscott that

the little wagon with its floor of moss and willow branches broke one's heart it was so beautiful_. . . of course there were no kings there-the king was being buried and there were no others. ${ }^{104}$

Bleaker and more telling, perhaps, was his distraught remark, loyally quoted by Georgiana: "I am quite alone, now, quite, quite." 105

\section{harles J. Faulkner}

Morris's lifelong friendships with Charles Joseph Faulkner, Philip Webb, and Cormell Price reflected other aspects of his character. Unlike Burne-Jones and Rossetti, Faulkner and Price are not well known, and so there are fewer public traces of their actions and idiosyncrasies. In recent years articles have appeared on other early Morris associates Vernon Lushington and William Fulford as well as Peter Paul Marshall, a founding member of Morris, Marshall, Faulkner and Co., but perhaps because of his mathematical career, early death, and lack of descendants, Faulkner seems to have attracted less interest from historians or family memoirists, with the exception of an ODNB article by William Whyte and a history of University College, Oxford, that provides hitherto unpublished information on his Oxford career. ${ }^{106}$

Born the year before Morris, and like Burne-Jones from Birmingham, Faulkner (1833-92) was the son of a maltster and brewer, Benjamin Faulkner, and his wife Ann Wight. He was educated at the Birmingham proprietary

103. Lago, ed., Burne-Jones Talking, 168.

104. Burne-Jones, Memorials, 2:289.

105. Ibid.

106. For articles on Fulford, see note 73. See also Keith Gibeling, "Peter Paul Marshall: Forgotten Member of the Morris Firm," JWMS 12.1 (1996): 8-16; and David Taylor, "Vernon Lushington: Practising Positivism," diss., University of Roehampton, 2008.

Mackail collected reminiscences from R. W. Dixon and Burne-Jones for his biography, but by then Faulkner had died and Burne-Jones and Faulkner had not been close. 
school and matriculated at Pembroke College in 1851 at age eighteen, where he notably failed the College's preliminary exams in divinity before turning to his chosen subject of mathematics. ${ }^{107}$ Morris and Faulkner met at Pembroke in 1854, ${ }^{108}$ and Faulkner became the only one of Burne-Jones's 'Brotherhood' whose chief accomplishments were not artistic or literary, though he seemed willing to engage in amateur artistic efforts in support of his friends' efforts. At Oxford he earned two firsts in mathematics and one in natural science, won junior and senior mathematics scholarships, and was elected to a Fellowship at University College in 1856 and appointed a tutor in 1857. In 1857 Faulkner joined the "Jovial Campaign" to paint the panels of the Oxford Union Debating Hall; Burne-Jones recorded that "Charley comes out tremendously strong on the roof with all kinds of quaint beasts and birds." ${ }^{109}$ In 1858 he traveled with Webb and Morris to France, and the next year he served as best man at Morris's marriage with Jane Burden. Faulkner never married, and Georgiana Burne-Jones described him in 1861 as the oldest son of a widow, with one younger brother and two sisters, Lucy and Kate. For many years Kate Faulkner prepared tiles, gesso work, and designs for Morris and Co., and Lucy Faulkner Orrinsmith published a small book on house furnishings in $1877 .{ }^{110}$

In many ways, Faulkner shared the more physically vigorous, concretely skeptical, and politically alert sides of Morris's character. Dixon's "Memoirs" describe him as Morris's fishing and boating partner at Oxford; ${ }^{111}$ he loved practical jokes, which Morris seemed to bear patiently as a kind of therapy for his inexplicable temper; and he shared Morris's great love of strenuous travel, his remarkable patience and dexterity in the execution of handicraft designs, and his conscientiousness in practical affairs. He was also a founding partner of 'the Firm'-Morris, Marshall, Faulkner and Co._-which he served as accountant and assistant, and in order to work for this new enterprise he resigned his tutorship and left Oxford for employment in London, supplementing his $\mathfrak{£} 150$ annual salary from the Firm by working as an engi-

107. William Whyte, "Charles Faulkner"; Robin Darwall-Smith, A History of University College, Oxford. Whyte states that he was the second son of Benjamin Faulkner and his wife Ann; May Morris recalled visits to Mrs. Faulkner and her daughters in London (CW, 3:xxvxxvi).

108. The 'Set' met nightly in Faulkner's rooms, where, Burne-Jones recalled, "about nine of the evening Morris and I would often stroll down together, and settle once for all how all people should think." (Mackail, Life, 1:35).

109. From a letter home, ibid., 120.

110. The Drawing-Room: Its Decorations and Furniture (London: Macmillan, 1878). See Emma Ferry, “The Other Miss Faulkner': Lucy Orrinsmith and the 'Art at Home Series."”

111. "Memoir of William Morris," ed. Boos, 19. 
neer for an engineering firm from 1861 to 1864 . In Mackail's account, he had been "unable to bear the loneliness of Oxford now that all the rest were gone," and had "resigned the mathematical tutorship which he held together with the Fellowship at University, and had come to London to learn the business of a civil engineer. As a man with a head for figures, who could keep the accounts of the business, he was a valuable associate; and ... he contributed a good deal of work as a craftsman. He helped in executing mural decorations; he painted pattern-tiles, and figure tiles on which the design had been drawn by a more skilled hand; and he even, in March, 1862, successfully cut a wood-block, on which Rossetti had drawn the well-known illustration for his sister's poem of 'Goblin Market."'112 During this period Faulkner described the Firm's activities in letters to Cormell Price, then in Russia, remarking at one point that he had fired the furnaces to make glass, ${ }^{113}$ and describing with detached amusement a typical meeting of the partners, which had "rather the character of a meeting of the 'Jolly Masons' or the jolly something else than of a meeting to discuss business."

Beginning at 8 or 9 p.m. they open with the relation of anecdotes which have been culled by members of the firm since the last meeting. These stories being exhausted, Topsy and Brown will perhaps discuss the relative merits of the art of the thirteenth and fifteenth century, and then perhaps after a few more anecdotes business matters will come up about 10 or 11 o'clock and be furiously discussed till 12,1 or $2 .{ }^{114}$

When the Firm dissolved in 1874, Faulkner renounced his legal claim in favor of Morris, along with Burne-Jones and Webb, and against the opposition of Peter Paul Marshall, Rossetti, and Ford Madox Brown. May later remarked of the dissolution that "there is no doubt that he [Morris] felt the break-up keenly at the time, though his nearest friends could not fail him then or thereafter-the sun could more easily go backward." 115

By 1864 Faulkner needed more income than the Firm could provide, and he returned to University College, Oxford, becoming a praelector in mathematics, though he spent his vacations in London. Whyte describes him as among a small group of tutors that founded a series of combined collegiate

112. Mackail, Life, 1:145-46. For a brief period Faulkner was paid $£ 150$ annually for his services as bookkeeper (153). William Whyte notes that he helped in painting the interior of several churches $(O D N B)$.

113. W. R. Lethaby, Philip Webb and His Work, 32.

114. Salmon and Baker, William Morris Chronology, 11 April 1861.

115. CW, 11:xii. 
lectures in mathematics in the late 1860 , lecturing on a range of topics. ${ }^{116}$ Though this is seldom mentioned in his friends' recollections, Faulkner also had a successful administrative career, serving as bursar (vice-bursar, 186466; senior bursar, 1866-82); dean, 1871-75; dean of degrees, 1875-89; registrar, 1866-82; and librarian, 1884-89. These were years in which University College expanded the range of subjects available for study and opened its fellowships and scholarships to those not intending to become clergymen, and as tutor and administrator, Faulkner would have advocated for and participated in these shifts. His artistic concerns are reflected in his successful opposition to an 1873 proposal to decorate a College addition in a High Gothic design, a style by then associated with ecclesiasticism and conservatism, and when former Master's Lodgings were converted into student rooms, he arranged for the College to order Morris and Co. wallpaper. ${ }^{117}$

According to Whyte, Faulkner took his administrative roles "very seriously, visiting college properties, managing college revenues, and cataloguing the college archives." 118 The archives of University College confirm his meticulous concern that college properties contain proper sanitary provisions and were in good repair; cold to ecclesiastical appeals, he favored the division of land to provide smaller livings and other means of helping less prosperous tenants to survive hard times. ${ }^{119}$ In the 1870 os fellows would have received somewhat above seven hundred pounds a year, and College offices and a tutorship would have brought this to about a thousand pounds. ${ }^{120}$ Perhaps the added income from these administrative posts was needed for Faulkner to help support his sisters and donate to causes in which he believed; as we shall see, he was a generous contributor to Commonweal and the Socialist League. His efforts enabled him to leave at his death the quite respectable estate of $£_{5,072}$, still less than one-tenth that of Edward Burne-Jones. ${ }^{121}$

116. Whyte records that in $1871 / 2$ Faulkner gave a series of lectures on elementary differential calculus, problems in "mixed mathematics," "differential calculus and applications," and "dynamics of a particle," all relatively elementary topics. Letter to author, 28 July 2010.

Rather strikingly, Faulkner was the last Fellow in mathematics to be appointed at his college until 1962 (Darwall-Smith, History, 502). From time to time he was called upon to defend the sciences in a still largely clerical setting, and one of his students who was later to receive a "first" in natural science recalled that Faulkner had defended his work when he was criticized by another tutor for his ignorance of Gospel miracles.

Class snobbery persisted; the same student recalled that "the Fogger" was mocked for his Mercian speech and "Birmingham boots" (ibid., 371). Darwall-Smith notes that as late as the $188 \mathrm{os}$, "some undergraduates, valuing gentlemanly ways above intellectual achievement, found some Fellows-like the Brumme Charles Faulkner-hard to respect" (403).

117. Ibid., 367. He and another Fellow, Charles Fytte, had opposed the High Gothic style.

118. Whyte $(O D N B)$.

119. University College Archives, 1859-85, UC:EB4/J1, 1-6. Faulkner resigned in 1882.

120. Darwall-Smith, History, 398.

121. Whyte $(O D N B)$. 
One of Charley's less subtle traits, mentioned earlier, was a fondness for bad practical jokes, sometimes at Morris's expense. Once at Red House he and Burne-Jones threw apples at Morris, then teased him for having a black eye. ${ }^{122}$ Another time, during the early days of the Firm, Faulkner arranged for books and candlesticks to fall on Morris's head during a meeting, and

bumping and rebounding they rolled to the ground, while Morris yelled with the enraged surprise of startled nerves, and was understandably very near to serious anger, when Faulkner changed everything by holding him up to opprobrium and exclaiming loudly in an injured voice, "What a badtempered fellow you are!" The "bad-tempered" one stopped his torrent of rage-looked at Faulkner for a second, and then burst into a fit of laughter, which disposed of the matter. ${ }^{123}$

On still another occasion, later recalled by Webb, "After Morris had had a 'storm,' Faulkner put a label, 'He is mad,' in his hat, and then walked out."124

Morris eventually learned to put up quite equably with the nonsense of his friends. The Memorials record Burne-Jones's account of a later expedition:

How we teased Mr. Morris on the river [at Oxford in 1875]. We took our lunch one day, and it was a fowl and a bottle of wine and some bread and salt-and Mr. Faulkner and I managed to hide the fowl away in the sheet of the sail, and when we anchored at a shady part of the river and undid the basket, lo! There was no fowl. And Mr. Morris looked like a disappointed little boy and then looked good, and filled his dry mouth with bread and said it didn't much matter, so we drew out the fowl and had great laughter. ${ }^{125}$

Most remarkably, Faulkner cheerfully accompanied Morris on his two arduous trips to Iceland in 1871 and 1873. Of these journeys, May Morris remarked that

122. Burne-Jones, Memorials, 1:220.

123. Ibid., 226.

124. Lethaby, Philip Webb and His Work, 21.

125. Burne-Jones, Memorials, 2:58. She recounts another occasion on which Burne-Jones and Faulkner took great delight in deceiving Morris in a game of whist played with a dummy (ibid., 1:279).

Faulkner's name appears steadily throughout the Memorials in the accounts of decorating at Red House and social events for the Firm; and when the Morrises and Burne-Joneses took a joint holiday in Oxford in 1867, "Faulkner was in college, but we met every evening, and then Morris read what he had written or the men played whist-without practical jokes now. I remember noticing how beautifully Faulkner shuffled the cards with his skillful fingers" (ibid., $1: 304)$. 
his [Morris's] courage . . . was nothing to that of Charley Faulkner. My father's old college-friend was not in good health and thought the careless open-air life would benefit him ... but he went chiefly out of sheer affection for my father, interested in, though not sharing his absorbing passion for the things of the North. He suffered untold miseries ..., endured the long days in the saddle the best he might, and during the journey was several times on the verge of illness ... his shortsight almost amounted to blindness, and many a time the wisdom of those admirable little ponies ... saved him from disaster. Yet with all this, and not living in the magic dream that possessed his friend, he managed to keep going by sheer pluck and enjoyed it, rough times and smooth times and all. ${ }^{126}$

Finally, like Webb but unlike Burne-Jones, Faulkner saw eye to eye with Morris politically. He co-authored with Cormell Price an early article on "Unhealthy Employments" for the Oxford and Cambridge Magazine, ${ }^{127}$ with its conclusion that "indifference to others' misery is a crime which cannot go unpunished" (271). He joined Price, Morris, and the Burne-Joneses at the demonstration of "workmen's neutrality" in 1878, and when in 1886 Morris was arrested for "obstruction" (that is, lecturing on socialism at Bell Street, Edgeware Road), Faulkner testified in his defense. Most significantly, as a don he helped found an Oxford branch of the Socialist League in 1885, and Tony Pinkney describes him as its "driving force . . . from the beginning." ${ }^{228}$ The inner alienation he must have experienced as an administrator as well as his wholehearted enthusiasm for socialism are shown in his comment: "It makes me feel fresh again to be aiming at something in which I can feel an interest, after the miserable dreary twaddle of university life."129

Faulkner also gave $£ 100$ towards the inauguration of Commonweal, to which he contributed two articles in 1887 and 1888, before he was paralyzed by a stroke in October of the latter year. The 1887 article, "Inhuman Arithmetic," attacks political economy for reducing men to ciphers. Like Philip Webb, Faulkner was an anti-parliamentarian, and in "Law and War," which appeared

126. $C W, 8: \mathrm{xv}$.

127. "Unhealthy Employments," Oxford and Cambridge Magazine, May 1856, 265-71. The authors document some of the worst industrial hazards of the period and offer practical and political remedies. Mackail remarks, "Price and Faulkner brought to Oxford actual knowledge of the inhuman conditions of human life in the great industrial areas; their special enthusiasms were for sanitation, for Factory Acts, for the bare elements of a possible life among the mass of their fellow-citizens" (Life, 1:64).

128. An account of Faulkner's role in the Oxford Socialist League appears in Pinkney, William Morris in Oxford: The Campaigning Years, 1874-1895, 107-12. He notes that after Faulkner's stroke the Branch "was in danger of being left entirely rudderless without him."

129. MacCarthy, William Morris, 515. 
in the Commonweal issue of January 7,1888 , and the two succeeding weeks, he asserted (as did Morris) that "we shall not be flurried by the thought of the great struggle which shall put an end to it all." In a letter from Faulkner to Joseph Lane of May 18, 1887, commenting on Lane's Anti-Statist Communist Manifesto, he argued against its direct attacks on religion and expounded a kind of libertarian anarchism:

What we wish to do is destroy authority, and among other authorities that will disappear will be those who pretend to know more than others about "the next world" and about "god" ... we may safely leave all men to speculate freely ... the socialist should be free to think and to speculate on any subject whatever... what he is forbidden to do, which is the very aim of socialism to prevent, is the interfering with other people. ${ }^{130}$

Faulkner's efforts on behalf of socialism drew some local opprobrium; in 1885 the Oxford Magazine described his views as "alehouse anarchism," and hostile undergraduates christened a donkey "Comrade Faulkner" after their College librarian and Dean of Degrees. ${ }^{131}$ Even the Daily Telegraph objected when Faulkner joined Morris in supporting the defenders of Khartoum against General Gordon: "He denounces public men all around[, asserting that] . . . Colonel Burnaby [a cavalry officer killed in the attempt to retake Kartoum] - for even death does not disarm his criticism—was a scoundrel." ${ }^{132}$

MacCarthy claims that Faulkner "devoted all his energy to Morris and the Socialist League, jeopardizing his academic career; ${ }^{133}$ she may be following Mackail's rather dour view of the effect of Faulkner's political activities:

The work and all the load of toil and obloquy it involved had almost been too much even for Morris's immense energy and bounding vitality: on the weaker constitution of Faulkner it would seem to have acted with dangerous and finally fatal result. ${ }^{134}$

130. B. L. MS. 46,345, in “Charles Faulkner," Florence Boos, ed., William Morris's Socialist Diary, London: Journeyman Press, 1985, 52.

131. Oxford Magazine, 3 (1885), 58; Whyte (ODNB).

132. The Daily Telegraph, 17 February 1885; Kelvin, Letters, 2:39on2.

133. MacCarthy, William Morris, 578. She notes that "the League files in Amsterdam hold the poignant records of his efforts: his fruitless attempts to get the newsagents in Oxford to distribute Commonweal; his donation of his MA gown, now green with age, for a Socialist League performance; his and Webb's subsidy of the League. They were both paying one pound toward salaries and one pound to the Commonweal fund every week in 1888." She attributes Morris's grief at Faulkner's stroke to guilt. In view of the general hostility toward socialism of the Oxford establishment, MacCarthy may be correct that Faulkner's socialism jeopardized his career, but she does not provide evidence.

134. Mackail, Life, 2:218. 
Faulkner suffered a stroke in 1888 at the age of 55, and remained paralyzed, though not unconscious, and was cared for by his sister Kate in London until his death in 1892. MacCarthy's view of the causes of his stroke seems a mild echo of Burne-Jones's comment on Faulkner's death, "Oh yes, [his socialism] killed him, by the most painful of deaths." 135 Since Faulkner had been in ill health as early as fifteen years earlier, this seems a stretch, but such responses cast in relief Faulkner's intrepidity in standing by the beliefs he shared with his friend. As such books as Maurice Ashley and C. T. Saunders's Red Oxford: A History of the Growth of Socialism in the University of Oxford (1930) and Tony Pinkney's William Morris in Oxford: The Campaigning Years, 1879-1895 (2007) have argued, the efforts of early socialists to promote their ideas in a university known for its conservative politics were not without some later influence; had Faulkner lived another fifteen years he might have been gratified to find allies in another generation.

All records of Faulkner's character in fact confirm Val Prinsep's late recollection of him as "the most genial of men."136 For example, Georgiana BurneJones remembers Faulkner's attentiveness to Ford Madox Brown's eldest son: "The little ten-year-old Nolly sat up all evening and clung most of the time to kind Charles Faulkner, demanding amusing stories from him." ${ }^{137}$ To his friend and biographer W. R. Lethaby, Philip Webb later spoke of Faulkner as "the man of the clearest honesty" he had known. "He was most invincibly kind, loyal and persistent and Morris's truest follower." ${ }^{138}$ He remembered Faulkner's kindness to the undergraduates at Oxford, and of his having taken special care of one much-teased youth. Webb believed that "Socialism was a great gain to him too: in the early times he felt too severely towards the orthodox." 139

To Mackail in June 1898, Webb wrote that

as to the friendship to the last between the two men: assuredly it was that of the greatest confidence and affection. The unbreakable courage and clear honesty of Faulkner held Morris as closely as friendship, pure and simple, could bind two men together-regardless of difference in quality of mind. They each did for the other what they could not have done for anyone

135. MacCarthy, William Morris, 579.

136. Valentine C. Prinsep, "The Oxford Circle: Rossetti, Burne-Jones and William Morris," Magazine of Art 27, n.s. 2 (1904): 171; Prinsep describes Faulkner as "a clever and very ingenious man."

137. Burne-Jones, Memorials, 1:293.

138. Lethaby, Philip Webb and His Work, 246.

139. Ibid., 247. 
else. . . . C. J. F. had the capacity of seeing the value of that towards which he had no natural attraction; and this, to me, seems to be one of the rarest fine qualities. ${ }^{140}$

Charles Faulkner was a quiet, unpretentious man of acute skeptical intelligence, whose "clear honesty" aided Morris in essential ways. His steady support for the more active and iconoclastic sides of Morris's character comes through in the recollections of their more conventional friends, and his accompaniment of Morris to Iceland was a significant mark of friendship and devotion. It was not only on the ponies in Iceland that "Morris's truest follower" rode with Morris through "the rough times and smooth times and all." His incapacitation in 1888 deprived the latter of important emotional and intellectual support as he encountered factionalism and disappointments in his socialist endeavors of the late 188 os and '9os.

\section{ormell Price}

Morris was very close to Cormell Price in his last years at Oxford, and his letters to him have a very rare, openly affectionate and sentimental tone. Price was unfortunately forced to leave London after 1860, which deprived the two friends of what would have been a deeper day-to-day association; as it was, they continued to visit each other when they could throughout their lives.

Cormell ["Crom"] Price was born in 1835, a year later than Morris and Faulkner, and two years later than Burne-Jones and Dixon. He attended King Edward's School with Ned Jones, Harry Macdonald (older brother of Georgiana Macdonald), and Wilfred Heeley, another later contributor to the Oxford and Cambridge Magazine. At thirteen he became the older Jones's closest friend, and shared with him interests in obscure historical topics and the collecting of "relics." ${ }^{141}$ Price's younger sister Fanny later remembered joint Price-Jones performances of comic parodies; Dixon recalled that at Oxford Cormell helped organize readings of Shakespeare; and Fulford wrote Fanny in 1859 that he had come upon Crom and Faulkner reading aloud from a French play. ${ }^{142}$ Price seems also to have shared Morris's and Faulkner's social conscience; he recorded an 1855 conversation with Morris on "the organi-

140. Philip Webb to J. W. Mackail, 4 June 1898; Mackail notebooks, WMG, cited in MacCarthy, William Morris, 578.

141. Burne-Jones, Memorials, 1:37.

142. Ibid., 193. 
zation of labour," ${ }^{43}$ co-authored the article with Faulkner on "Unhealthy Employments" mentioned earlier, and contributed an essay on "Lancashire and Mary Barton" to the Magazine. ${ }^{144}$ According to Georgiana Macdonald, he once responded to their gymnast friend Angus MacLaren's fear of thunderstorms with a bit of rejected common sense:

Mr. Price good-naturedly took upon himself the task of reviving conversation. He always had a turn for statistics, and this time thought to cheer the company by announcing in a pleasant voice that it was a well-established fact that one ill-kept pig-sty did more harm than twenty thunder storms; . . . as a cannonade of thunder saluted the statement, MacLaren angrily exclaimed: "Price, you should be ashamed of yourself . . . !" and the well-meant effort failed. ${ }^{145}$

Five of Morris's rare extant undergraduate letters were written to Crom Price in 1855; expansive and affectionate, they provide the best glimpse we have into Morris's mental and emotional life at Oxford. (Either Price's replies were unusually stimulating, or he was an especially sympathetic listener, or both; for similar remarks could be made of the earlier letters to him in Birmingham from Burne-Jones.)

Morris wrote the first two letters during "Holy Week" in 1855, just after he had begun to read poems to his friends. The first begins with a warm apology:

Yes, it's quite true, I ought to be ashamed of myself. . . please forgive me. As the train went away from the station, I saw you standing in your scholar's gown, and looking for me. If I hadn't been on the other side, I think I should have got out of the window to say good-bye again. ... Ted will shew something to criticize, or stop, I may as well write it for you myself; it is exceedingly seedy. . . . I have begun a good many other things, I don't know if I shall ever finish them, I shall have to show them to Ted and to you first: you know my failing. I have been in a terrible state of mind about my writing; for I seem to get more and more imbecile as I go on. ${ }^{146}$

Such self-deprecation contrasts noticeably with his friends' eager praise.

143. Ibid., 116.

144. The essay, which evinces considerable reading on the topic, discusses the inequalities of labor relations and advocates trade unionism, a more progressive view than that advanced by Elizabeth Gaskell's novel.

145. Burne-Jones, Memorials, 1:181.

146. 3 April 1855, Kelvin, Letters, 1:8, 10. 
The effort Morris encloses is "'Twas in Church on Palm Sunday," which begins conventionally enough with Judas's kiss of betrayal, broods on other, more erotic betrayals, and pauses for a grand half-cadence of undergraduate gloom:

Christ, thine awful cross is thrown

Round the whole world, and thy Sun

Woful kisses looks upon, (st. 15)

This is followed by confession:

Very blue the sky above,

Very sweet the faint clouds move,

Yet I cannot think of love. (st. 18)

Betrayals and fears of sexual competition between comrades recur in several Morris writings: in "Gertha's Lovers," for example, in the Oxford and Cambridge Magazine; in "Rapunzel" in The Defence of Guenevere; most strikingly, in the 1869 "The Lovers of Gudrun"; and in more muted form in the 1885 Pilgrims of Hope.

The poem's most sustained image is of successfully sublimated heterosexual love. A monk watches as a deacon and his female partner progress hand in hand toward a numinous Presence, perhaps in a marriage ceremony, after which a diffuse "kiss on dying forehead given" precedes a general translation into heaven.

Kiss upon the death-bed given,

Kiss on dying forehead given

When the soul goes up to Heaven.

Many thoughts beneath the sun

Thought together; Life is done,

Yet for ever love doth run. (sts. 12-13)

The scene and narrative situation uncannily resemble those of "The Three Flowers" and "Fame," both written in the same period, and of "The Story of the Unknown Church," his first published prose tale, written a year later. Schillerian embraces and kisses of benediction are a motif of Morris's earliest poems and prose tales, as is the prototypically Morrisian affirmation that "Yet for ever love doth run." 
The poem's rather extravagantly elegiac content explains some of Morris's mingled apologies and self-deprecation. He seems embarrassed less by the poem's literary flaws than by its troubling emotions, and since the friends may also be reluctant to discuss the psychological implications of such poetic confessions, he alludes to them only indirectly.

Cormell's reply seems to have commented on the poem's "shady" (slant) rhymes. In reply, Morris acknowledges that the rhymes may be weak and the content sentimental, but defends the poem in personal terms:

It is very foolish, but I have a tenderness for that thing, I was so happy writing it, which I did on Good Friday: it was a lovely day, with a soft warm wind instead of the bitter north east wind we had had for so long. ${ }^{147}$

There may be something deeper in this argument as well. Morris's later defenses of poetry-in the "Apology" and "L'Envoi" to The Earthly Paradise, for example-essentially elaborate what might be called a "writer-response theory": the process of composition should engender enjoyment for the writer and modify consciousness in any way ultimately desirable and useful. In effect, he later argues, acts of writing should witness forms of life which they reflect as well as continue. If such acts are to be "useful work," not "useless toil," they should also-like other work-be enjoyable as performed, and not justified in terms of derived benefits, such as readers' eventual responses. The latter of course will distinguish some efforts as "works of art" and others as doggerel, but such discrimination remains derivative and passive unless it recreates something in its turn-fashions some new extension or modification of consciousness in its judgment. When it does this, however, it ceases to be just reader's or hearer's response, and becomes a writer's or composer's response as well. Morris's later essays on art and labor all repeat the same demand: that useful work be enjoyable as it is performed; not justified in terms of later 'consumption' of an artistic or other product.

Morris's defense of the rhymes themselves is concessive but persistent:

the rhymes you call shady, I should like to be able to defend: . . . they are makeshifts, dear Crom; it is incompetency; you see if I must lose the thought, or sacrifice the rhyme to it, I had rather do the latter and take my chance about the music of it. ${ }^{148}$

In effect, this mixes an apology for the uncertain virtues of artless directness

147. April 1855, ibid., 11.

148. Ibid. 
with an oblique claim for the "music of it," and for the thought which composes that music through a natural process: "Perhaps I may be able in the course of time to rhyme better, if my stock of thoughts are not exhausted, and I sometimes think they mayn't all be gone." ${ }^{149}$ The letter to Price takes a different turn when he tries to explain-"sad muddle head" that he is-his responses to Shelley's "To a Skylark." It is "gorgeous," and "utterly different to anything else I ever read," for reasons that prompt an account of the effects of poetry:

Most beautiful poetry, and indeed almost all beautiful writing, makes one feel sad, or indignant ... ; but "The Skylark" makes one feel happy only; I suppose because it is nearly all music, and that it doesn't bring up any thoughts of humanity. ${ }^{150}$

Some fledgling version of a familiar tension in Morris's lifework appears in this suggestion that "beautiful poetry, indeed almost all beautiful writing" should arouse empathetic "indignation," in contrast to something that is "nearly all music," and that "doesn't bring up any thoughts of humanity." Whatever the merits of this distinction, Morris's response would seem to ignore some nuances of Shelley's poem:

We look before and after,

And pine for what is not:

Our sincerest laughter

With some pain is fraught;

Our sweetest songs are those that tell of saddest thought. (1l. 86-90)

In any case, Morris's remarks indicate a reservoir of melancholy released by poetry, a tendency toward projective readings, and a growing recognition of the paradoxical comfort of "sweetest songs . . that tell of saddest thought."

The third of the extant letters to Price was written after Morris learned Crom could not accompany him, Fulford, and Jones on a planned trip to France. Morris briefly describes a failed literary effort, solicits advice, and modestly offers a gift:

I have finished the tale I began last term and failed signally therein, I'm afraid that it won't do for the "Brotherhood"; I am going to send it to Dixon

149. Ibid.

150. Ibid. 
and Ted to look at. . . . will you look at it too? ${ }^{151} \ldots$. . I bought some engravings from Fra Angelico's picture in the Louvre, I am afraid only pretty good; will you have them? ?52 $^{15}$

The fourth letter, from France, both opens and closes with the now-familiar abashed disclaimers:

Dearest Crom. ... I am quite uncomfortable even now about writing a letter to you, for I don't know what to say. ... This is a seedy letter to send to such a fellow as you are, Crom, please forgive me..$^{153}$

Between them is an excellent account of his second visit to France.

During the first visit in the Long Vacation of 1854, he had seen for the first time paintings by Van Eyck and Memling, and the churches at Amiens, Beauvais, Chartres, and Rouen, and he remembered this experience for the rest of his life. ${ }^{154}$ On this second trip he was no less exultantly happy:

I almost think I like that part of the country [near Dreux] better than any other part of the lovely country we have seen in France; so gloriously the trees are grouped, all manner of trees, but more especially the graceful poplars and aspens, of all kinds; and the hedgeless fields of grain, and beautiful herbs that they grow for forage whose names I don't know, the most beautiful fields I ever saw yet, looking as if they belonged to no man, as they were planted not to be cut down in the end, and to be stored in barns and eaten by the cattle, but that rather they were planted for their beauty only. ${ }^{155}$

"Twas in Church on Palm Sunday" had expressed the emotional and aesthetic world of Morris's juvenilia; this description evokes for the first time the intense psychological world of the early prose romances, in which profusion and variety of beautiful landscape is defined at least in part as freedom from possession ("looking as if they belonged to no man") or even use ("not to be stored in barns and eaten by the cattle"). Like his adolescent celebrations of

151. Since Morris had visited Amiens Cathedral with his sister Henrietta in 1854, this draft may be of "The Story of the Unknown Church," set in a church that resembles the cathedral and published in the January issue of The Oxford and Cambridge Magazine; alternately it could be "A Dream," published in the March issue.

152. Kelvin, Letters, 1:13-14.

153. Ibid., 19, 22.

154. "The Aims of Art," CW, 23:85.

155. Kelvin, Letters, 1:20. 
the "water meadow", this remarkable sentence rushes on until it becomes a small emblem of the green fuse it praises:

that they might grow always among the trees, mingled with the flowers, purple thistles, and blue corn-flowers, and red poppies, growing together with the corn round the roots of the fruit trees, in their shadows, and sweeping up to the brows of the long low hills till they reach the sky, changing sometimes into long fields of vines, or delicate, lush green forage; and they all looked as if they would grow there for ever, as if they had always grown there, without change of seasons, knowing no other time than the early August. ${ }^{156}$

The same preoccupation with timelessness ("as if they would grow there for ever") and history ("as if they had always grown there") suffuses the descriptions of the early prose romances. Another passage, on railroads, is thoroughly characteristic in a different way:

We had to leave it [a valley along the Eure] and go to Rouen by a nasty, brimstone, noisy, shrieking railway that cares not twopence for hill or valley, poplar tree or lime tree, corn poppy, or blue cornflower, ... . tower, or spire, or apse, or dome, till it will be as noisy and obtrusive under the spires of Chartres or the towers of Rouen, as it is [under] Versailles or the Dome of the Invalides; verily railways are ABOMINATIONS; and I think I have never fairly realised this fact till this our tour...

... We saw the church there [at Dreux] with a transept front very elaborately carved once, now very forlorn and battered, but (Deo gratias) not yet restored. ${ }^{157}$

This is no longer the voice of 'Top', but of William Morris-enemy of "restoration," future socialist ("looking as if they belonged to no man"), intemperate railroad-hater, and friend of the earth ("almost all beautiful writing makes one feel sad, or indignant”). Georgiana Burne-Jones later reported Ned's recollection that "Morris in his wonderful way knew everything about every place they went to." 158

The intensity and freedom of this second trip in the company of friends finally made abandonment of the ministry inevitable. Camaraderie and

156. Ibid.

157. Ibid., 21-22, 20-21.

158. Burne-Jones, Memorials, 1:114. 
exposure to new forms of beauty and traces of threatened medieval culture prompted a new determination and sense of purpose, which Edward BurneJones later recorded in a justly famous passage:

It was while walking on the quay at Havre at night that we resolved definitely that we would begin a life of art, and put off our decision no longer-he should be an architect and I a painter. It was a resolve only needing final conclusion; we were bent on that road for the whole past year, and after that night's talk we never hesitated more. That was the most memorable night of my life. ${ }^{159}$

Other traces of these trips remained always in Morris's sensibility ("I first saw the city of Rouen . . . no words can tell you how its mingled beauty, history, and romance took hold on me"). ${ }^{160}$ Both the prose romances and many of the finest and most deeply felt poems of The Defence of Guenevere are implicitly set in such landscapes, and express Morris's ardent attraction to the preindustrial French countryside.

Some early evolving consequences of his decision appear in two rather pained letters. In the first, written in November 1855, as mentioned earlier, he tries to explain his new course of action to the mother who hoped he would become a bishop. In the second, dated July 1856, and the last of the extant early letters to Price, he gives an account of his efforts to become a painter. Both letters mix firm commitment to the substance of his decision with lingering hesitation about its form. To his mother, he pleads again, obliquely, the moral value of self-fulfillment, and of the creative work that he hopes someday to enjoy.

It will be rather grievous to my pride and self-will to have to do just as I am told for three long years, but good for it too, I think; rather grievous to my love of idleness and leisure to have to go through all the drudgery of learning a new trade, but good for that also. . . p perhaps I may reasonably hope to be happy in my work, and sometimes when I am idle and doing nothing, pleasant visions go past me of the things that may be. ${ }^{161}$

The letter to Price is likewise painful, but for a different reason:

Rossetti says I ought to paint, he says I shall be able; now as he is a very great man, and speaks with authority and not as the scribes, I must try. I don't

159. Ibid., 114-15.

160. "The Aims of Art," CW, 23:85.

161. 11 November 1855, Kelvin, Letters, 1:25. 
hope much, I must say, yet will try my best—he gave me practical advice on the subject. ${ }^{162}$

His strained deference to Rossetti is uncharacteristically other-directed, and the letter even more dogged and laborious in tone. Morris's personal motto (later mocked, ironically, by Rossetti) was "If I can"; and "love and work" - or perhaps love in work-remained for him a lifelong ideal. But the promises of self-fulfillment and enjoyment are gone ("One won't get much enjoyment out of life at this rate, but that don't matter: I have no right to ask for it."); and at Rossetti's bidding Burne-Jones's "life of art" began to look suspiciously like useless toil.

It would be interesting to know Price's comments on all this, for Morris alludes apologetically in a later passage to another interest that he knew Price shared:

I can't enter into politico-social subjects with any interest, for on the whole I see that things are in a muddle, and I have no power or vocation to set them right in ever so little a degree. My work is the embodiment of dreams in one form or another. ${ }^{163}$

The desire to "set them right" persisted, of course. It survived the frustrations of his apprenticeship to Rossetti, recurred in his work for the Firm and the $\mathrm{SPAB}$, and eventually proved more complexly interwoven with his "life of art" than Burne-Jones was able to follow. It only emerged in mature form when his utopian communist writings and active work for the Socialist League enabled him to fuse "politico-social subjects" and "the embodiment of dreams."

For his part, Crom Price devoted most of his energies from the early 1860 s onward to reformist pedagogy. Like Morris and Burne-Jones, he soon abandoned plans to enter the clergy, and he briefly read medicine in London after he left Oxford in 1858. In 1860 he accepted a seven-year appointment as a private tutor to the son of a Russian count, Count Orloff-Davidoff, and traveled with his employer's family in Europe before he accompanied them to Russia. A glimpse into his character is provided by Georgiana Burne-Jones, who remarked in the Memorials that "I do not think Cormell personally regretted his change of profession.... The experience of the dissecting-room was a terrible one to his nature." 164

Price missed his friends severely in Russia, however, and he returned early in 1863 to become a master at Haileybury College, where he later became

162. July 1856, ibid., 28.

163. Ibid.

164. Burne-Jones, Memorials, 1:216-17. 
Head of the "modern Side." In 1874 he became Headmaster of the United Services College at Westward Ho, where he gave the run of the college library to a lonely youth named Rudyard Kipling, Georgiana's nephew, who later remembered him fondly as the headmaster in Stalky and Co. (1899). As the editor of the school's newspaper prepared for his task,

Only the Head took an interest in the publication .... He gave Beetle the run of his brown-bound, tobacco-scented library; prohibiting nothing, recommending nothing. ... There were hundreds of volumes of verse-... Ossian; "The Earthly Paradise"; "Atalanta in Calydon"; and Rossetti-to name only a few. Then the Head, drifting in under pretense of playing censor to the paper, would read here a verse and here another of these poets, opening up avenues. And, slow breathing, with half-shut eyes above his cigar, would he speak of great men living, and journals, long dead, founded in their riotous youth; of years when all the planets were little new-lit stars trying to find their places in the uncaring void, and he, the Head, knew them as young men know one another. ${ }^{165}$

Over the years Price made frequent visits to the Morrises in London, and one of Morris's arguments to Janey for leasing a house in Hammersmith was that the added space would permit them to provide a bed for Crom on his holidays in London. ${ }^{166}$ Visits with Morris and his family are recorded for 1877 , $1878-81,1883,1885,1888$, and 1889 , and Cormell was one of those present to witness Morris's last will in September $1896 .{ }^{167}$

Like Morris, Cormell Price seems to have enjoyed entertaining friends; from 1866 through 1878 he maintained a 65-foot tower-retreat by the sea in Worcester, "Broadway Tower," whose visitors' book lists more than six hundred visits; Charles Faulkner came in 1868 and 1869, the Burne-Jones and Morris families in 1876, and the Morrises again in $1878 .^{168}$ Price later visited Paris with Burne-Jones in 1878; joined Morris, Faulkner, and the BurneJoneses at the 1878 Workmen's Neutrality Demonstration; and visited them all often. After the onset of Jenny's epilepsy, Price took a special and kindly interest in her, according to MacCarthy "becoming her adoptive uncle for

165. “The Last Term," Stalky and Co. (London: Macmillan, 1899).

166. 28 March 1878, Kelvin, Letters, 1:461.

167. Salmon and Baker, William Morris Chronology, 284; The Letters of Jane Morris, ed. Jan Marsh and Frank C. Sharp (Woodbridge, Suffolk: Boydell, 2013), document the continuing and affectionate relationship between the two families.

168. Lorraine Price, "Cormell Price, Esq., The Tower, Broadway." 
the remainder of his life." ${ }^{169}$ In late 1895 Cormell married Sarah Ann Hopper, formerly a servant at the United Services College, but Morris's death the following year prevented him from knowing their two children, Edward William (named in honor of Burne-Jones and Morris), born 1898, and Dorothy, born 1908. Cormell outlived all of his slightly older friends, and died at 75 in 1910. In his final illness he and his family moved to Rottingdean to live near Georgiana Burne-Jones, another testimony to the lifelong supportive ties maintained by these Oxford friends. ${ }^{170}$

\section{ONCLUSION}

I have retraced certain aspects of William Morris's early life and Oxford friendships with two aims. The first is to bring into relief what a remarkable group of friends this "brotherhood" was-not of course the better-known Pre-Raphaelite Brotherhood, but William Morris, Ned Jones, Charles Faulkner, Crom Price, and other friends such as Vernon Lushington, William Fulford, and later Philip Webb. The second is to explore the implications these friendships may have had for the development of Morris's early poetry and aesthetic. As mentioned, traditional scholarly views of this early period are somewhat biased by those of their most prolific source, the ardently aesthetic, art-catholic, and rather apolitical Edward Burne-Jones, filtered through the work of Georgiana Burne-Jones and her son-in-law, Morris's biographer, J. W. Mackail. As we have seen, Charles Faulkner and Cormell Price were equally supportive of Morris's earliest efforts to channel his great energies into "setting things right," as well as "a life in art," but they lacked later advocates of comparable presence and prestige.

More significantly, the letters and surviving documents make clear what a collective phenomenon this "Brotherhood" truly was. It was a network of several highly gifted individuals, rather than two "geniuses" and some peripheral satellites. Something in the complex exchange of letters, shared travels, and expressions of mutual aid and support suggests the collective

169. MacCarthy, 370.

170. Lorraine Price, “Uncle Crom: Kipling's Friendship with Cormell Price," Kipling Journal. Sarah Ann Elizabeth Hopper was born in 1863 in Northam, Devon, home of the United Services College. She was the daughter of Emma Hopper, Price's housekeeper, and at the time of their marriage Price was 60 and Sarah was 31. For a photograph of the Price family, see The Collected Letters of Jane Morris, 415. For information on Cormell Price's later life, I am indebted to historian Stephen Williams. 
narrators, "Wanderers," "Elders," and audiences of The Earthly Paradise-or even Morris's farewell in "L'Envoi" to the Book itself:

Good reason why I love thee, e'en if thou

Be mocked or clean forgot as time wears on;

For ever as thy fashioning did grow,

Kind word and praise because of thee I won.

Above all, the surviving letters and documents clearly show how deeply grateful Morris was to his gifted friends, a gratitude he expressed from the very first. The following direct tribute, for example, appears in his October 1855 letter to Price:

I am too old already, and there is no time to lose, I MUST make haste, it would not do for me, dear Crom, even for the sake of being with you, to be a lazy, aimless, useless, dreaming body all my life long, I have wasted enough time already, God knows; not that I regret having gone to Oxford, how could I? for I should be a very poor helpless kind of thing without Ted and you. ${ }^{171}$

An even more moving indirect tribute appears in a passage of the 1855 letter to his mother:

Your money has by no means been thrown away, if the love of friends faithful and true, friends first seen and loved here, if this love is something priceless, and not to be bought again anywhere and by any means. ${ }^{172}$

171. 6 October 1855, Kelvin, Letters, 1:23-24.

172. Ibid., 25. 


\author{
PREPARATION FOR \\ THE DEFENCE OF GUENEVERE
}

agiography is a dangerous art, and myths originally intended to praise may damage. Such a myth was the early belief that William Morris's Defence of Guenevere arose by spontaneous generation: that Morris wrote his first poem, "The Willow and the Red Cliff," in 1855 at twenty-two, and composed thereafter with incredible speed and little need of revision, though overwhelmed by his own loquacity from time to time, and forced to begin anew.

His lifelong friend Ned Jones, for example, recalled that "one morning, just after breakfast, [Morris] brought me in the first poem he ever made. After that, no week went by without some poem,"' and Richard Watson Dixon, later also a poet, remembered:

We sat down and heard Morris read his own poem, the first that he had ever written in his life. It was called "The Willow and the Red Cliff." As he read it, I felt that it was something the like of which had never been heard before. It was a thing entirely new; founded on nothing previous: perfectly original whatever its value, and sounding truly striking and beautiful, extremely decisive and powerful in execution. It must be remembered particularly that

1. Mackail, Life, 1:51. 
it was the first piece of verse that he had ever written; and then it will be acknowledged that this was an unprecedented thing. He reached his perfection at once; nothing could have been altered in "The Willow and the Red Cliff." . . . I remember his remark, "Well, if this is poetry, it is very easy to write." From that time onward, for a term or two, he came up to my room almost every day with a new poem. ${ }^{2}$

Alas for Morris, his youthful companions' recollections have been unjustly cited as evidence of his glibness and facility, and few have observed that he phrased his reply to Dixon ("if it is poetry") as a defeasible implication. He may, for example, have concluded in the end that "The Willow" was not "poetry" for he seems to have destroyed his original copy, along with a number of unused drafts for Defence poems, in 1858.

The aeolian-harp legend of Morris-the-automatic-writer may also have been reinforced by his first biographer J. W. Mackail's unawareness of a sheaf of seventeen poems Morris sent to his older sister Emma Morris Oldham from Oxford, and perhaps from Marlborough College. ${ }^{3}$ May Morris had relied on Mackail and the recollections of Morris's friends in 1914, when she reprinted "The Willow” as Morris's first poetic effort in the Collected Works, but when Emma died seven years later at ninety-one, her grandniece Effie Morris found seventeen copies of his early poems in a bureau drawer ${ }^{4}$ four in Emma's angular script, and thirteen more in Morris's early fair hand. May probably recognized "The Midnight Tilt" as an early version of "Winter Weather," an Oxford and Cambridge Magazine poem her father had omitted from The Defence of Guenevere, but the other poems were unfamiliar to her, and she printed eight of them in full in William Morris: Artist, Writer, Socialist ${ }^{5}$ (1936), her supplement to The Collected Works.

2. Dixon, "Memoir of William Morris," 21. R. W. Dixon deserves some gratitude for his ability and readiness to recognize the gifts of two greater poets-of Morris in his youth, and twenty-three years later of Gerard Manley Hopkins. To a surprising extent Dixon is a forgotten active participant in the early life of the Brotherhood; he first suggested the idea of The Oxford and Cambridge Magazine, and for a while he took up painting, took lessons from Rossetti, and lived with Jones and Morris at Red Lion Square. See James Sambrook, A Poet Hidden: The Life of Richard Watson Dixon 1833-1900, 62.

3. $C W, 21: \mathrm{xxx}-\mathrm{xxxv}$.

4. She was the daughter of Thomas Rendall Morris, an army officer whose unexpected death in 1884 left eight children, the youngest only two. Their mother had previously deserted them and left the country, and they were raised by their aunt Isabella Morris Gilmore with aid from Emma Morris Oldham. See Grierson, Isabella Gilmore, 33-36.

5. For the text of these poems, see The Juvenilia of William Morris, ed. Florence S. Boos (New York: William Morris Society, 1983) and the updated version, "Morris's Early Poems," in the William Morris Archive, http://morrisedition.lib.uiowa.edu/earlypoemstexts.html. 
Later in life Morris wrote his Socialist League comrade Andreas Scheu that "while I was still an undergraduate, I discovered that I could write poetry, much to my own amazement." Of the seventeen poems sent to Emma Oldham, only a few can be dated with certainty as from his Oxford period: "The Willow and the Red Cliff," "Palm Sunday," "Dear Friends, I Lay Awake in the Night," and "The Mosque Rising in the Place of the Temple of Solomon." Some of the others were possibly composed earlier, such as the following slight but cheerful poem in loose ballad quatrains, celebrating the natural recurrence of song: ${ }^{6}$

"The Blackbird"

Listen to the blackbird singing

To the red flush in the west

Of all that sing the spring in

The blackbird singeth best. ...

To the bees by the blossoms humming

The leaves will tell the tale

In the summer that is coming

As they flutter in the gale. ${ }^{7}$ (sts. 1, 4)

A bleaker and more nuanced landscape appeared in "The Willow and the Red Cliff":

That cliff it rises steep from the sea

On its top a thorn tree stands,

With its branches blown away from the sea,

As if praying with outstretched hands,

6. In Art and Forbidden Fruit, 11, John Y. Le Bourgeois argues that Morris's psychic life was dominated by pain over separation from Emma, and interprets "The Three Flowers" and "The Ruined Castle" as direct responses to Emma's engagement to Joseph Oldham. If this identification is correct, since Mr. Oldham courted Emma in 1848-49, this would mean Morris wrote the poems before he was sixteen. A later Morris biographer, Jack Lindsay, accepts this interpretation of "The Three Flowers," and thus the early date for these poems (William Morris: His Life and Work, 29-33). There is no explicit evidence for this dating, however, and Morris's later expressions of surprise at the ease of writing poetry could indicate that his university poems were indeed his first.

7. William Morris Archive, http://morrisedition.lib.uiowa.edu/earlypoemslistandtexts. html\#14. Omitted by May Morris from her compilations, it was also reprinted in The Juvenilia of William Morris, ed. Boos, 1983. Since the line indentations in Emma's copy are inconsistent, it is difficult to be certain of Morris's original intent. 
To be saved from the wind, from the merciless west,

That moaneth through it always

And very seldom giveth it rest

When the dark is falling pallwise. ${ }^{8}$

The noticeably starker quality of these lines suggested an awareness of recent works such as Wordsworth's “The Thorn," Coleridge's "Rime of the Ancient Mariner," Browning's Dramatic Lyrics (1846), and other less well-known works by minor poets of the 1830 and 1840 s, among them the much-maligned 'Spasmodics', who were known for their staccato line rhythms and use of compressed images as expressions of charged intensity. ${ }^{9}$

Friends had warned May Morris against attempts to recuperate Morris's early drafts and juvenile poems, but every aspect of her father's work and mental history interested her. She printed Morris's prose romances for The Oxford and Cambridge Magazine in volume 1 of the Collected Works, for example; inserted selections from unused Defence fragments into her introductions; and included in Artist, Writer, Socialist a discussion of Morris's habits of composition accompanied by quotations from his unpublished works. But her cautious relegation of his early poems to her introductions had the consequence that she provided little information about their dates and sources, and they remained unlisted in the tables of contents of The Collected Works. ${ }^{10}$ Her concern for her father's reputation, as well as the complex inner dialectic of purpose and accident, random negligence, and meticulous preservation, left many questions about these early drafts unanswered, and I have included a checklist of more than fifty of Morris's early poems and unused fragments for The Defence of Guenevere under the rubric Morris's Early Poems in the William Morris Archive (see http://morrisedition.lib. uiowa.edu/earlypoems.html).

What was interesting about these early efforts? One answer is that they bore witness not only to the nature and range of Morris's early reading but also to the extent to which he emerged quite early in life as an independent and self-directed personality. As mentioned, when asked once if the love of artistic things was an acquired taste, he remarked that it had been a pas-

8. See $C W, 21: x x x i$.

9. For a discussion of the Spasmodics, see the special issue "Spasmodic Poetry and Poetics," Victorian Poetry 42.4 (2004), ed. Jason Rudy and Charles LaPorte.

10. The 1973 reprint of The Introductions to the Collected Works of William Morris, with a preface by Joseph R. Dunlap (New York: Oriole Editions), also indexed May Morris's most important excerpts from early drafts, and K. L. Goodwin prepared a useful checklist in A Preliminary Handlist of Manuscripts and Documents of William Morris. 
sion with him from earliest childhood, which no one else in his family had shared, ${ }^{11}$ and at the age of seventeen he had refused outright to visit the widely admired Great Exhibition of 1851-an early manifestation of a lifelong resistance not only to 'civilized' notions of art but also to 'high-cultural' subservience to contemporary industrial technology.

There was nothing 'facile' about this renitence or, for that matter, the poetic skills that helped him articulate it, for both were well-grounded aspects of his temperament, consciously developed and guided by intertwined ideals of empathy, artistic consistency, and panentheistic conceptions of "nature" that opened into the past as well as the future. More oblique manifestation of these ideals could also be found in his intense desire to escape his own historical period; his stubborn belief in the power of sublimated love to inspire a worthy life (à la De la Motte Fouqué or The Heir of Redclyffe); and his recurrent preoccupation with the fates of distressed protagonists-often women humiliated by men-who found a measure of empathetic release and liberation in a death within nature.

Consider, for example, the allegorical poem "Fame," the longest of the juvenilia May Morris first published in 1936, with forty-nine stanzas of rhymed triplets. In it, Fame (here masculine) is tormented by initially unexplained guilt, for

... I know my name is sung

Among the banners; it is rung

Among the nations; hearts have clung

Around it, and it giveth birth

By its upspringing to the worth

That else were hidden in the earth. ${ }^{12}$

In his youth, Fame had experienced an oceanic fullness of affection and immersion in the forces of nature:

11. Wilfrid Scawen Blunt, My Diaries, 229. Of a conversation with Morris, Blunt recorded, "I took him yesterday to see Shipley Church. . . . We had a long discussion whether the love of beauty was natural or acquired. 'As for me', he said, 'I have it naturally, for neither my father nor my mother nor any of my relations had the least idea of it. I remember as a boy going into Canterbury Cathedral and thinking that the gates of heaven had been opened to me-also when I first saw an illuminated manuscript. These first pleasures, which I discovered for myself, were stronger than anything else I have had in life."'

12. May Morris, AWS, 1:521; poem is on pp. 518-23; William Morris Archive, http:// morrisedition.lib.uiowa.edu/earlypoemslistandtexts.html\#3. 
O! love was round him like a sea;

The love of all fair things that be,

The love of every beauteous tree....

The love of men that never die;

In many lands their bodies lie,

Their music, and their truth are nigh.

The love of those that come and go

About him, O! they loved him so,

And he loved them-but long ago. ${ }^{13}$

Once this "love of all fair things" had also been associated with a male friend whose "voice was ringing in my ears ...." and with a woman of noble emotions whose "eyes held sympathy / With all the sad, sad things that be. . ." "14

But no more. He had since fallen from this state of grace, traduced, perhaps, by overweening desire for the aforementioned "glorious destiny," and weeps now on a "little mound" near the graves of his lost friends, an attention to burial and mourning common in Morris's earliest writings. Fame's remorse and retribution for this nebulous betrayal ends the poem:

"I pray thee let love come again

The love I spurned; O! I am fain

To weep, that love may come again.”...

So weepeth he-so dieth he.

Cognate but less grandiloquent scenes of triangulated longing appeared in other early poems and tales. The mason in "The Story of the Unknown Church," for example (considered in more detail in chapter 4), begins what seems an account of his fondness for his sister Margaret, segues into an expression of fellow-feeling for Amyot, her fiancé, and ends at length in his selfless dedication to commemorating their love through his artistry. And in "Concerning Geffray Teste Noire," Morris's earnest speaker eulogizes a woman who has died with her lover, expresses reverence for their physical

13. AWS, 1:519-20.

14. If John Le Bourgeois and Jack Lindsay are correct in assuming that these early poems present Morris's sense of loss at the departure of his sister Emma, the absence of remarks on her physical appearance would be appropriate. 
passion, and commissions an elaborate carved grave to commemorate their (not his) love. ${ }^{15}$

Among the poems discovered by Morris's grandniece, several revealed cognate motifs of passion, sorrow, and detachment. In "The Abbey and the Palace," for example, time has reduced an abbey, a knight, and his dilapidated 'palace' to dust and stone, along with the passion, struggle, and reverence of his friends, enemies, anchorites, and comrades-in-arms who are joined in the fellowship of death. Within the abbey lies the effigy of a deceased knight:

Lying ... [b]y the ruined wall

With his hands clasped together,

Praying there for ever,

Look at the stone-carved Knight.

Many nineteenth-century poets had interpreted architectural ruins as images of human transience, but Morris rendered his homage to the forlorn building itself:

... all roofless,

All ruined and roofless

With the marble on the ground. ...

And the wind blows wearily

Round the palace, drearily

Standing, walls without a floor. ${ }^{16}$

In a later passage in his essay "The Churches of North France: Shadows of Amiens," Morris expressed a related sense that bare ruined choirs conveyed the lives and emotions of their creators:

I think those same churches of North France the grandest, the most beautiful, the kindest and most loving of all the buildings the earth has ever borne; .... A And those same builders, still surely living, still real now and capable of receiving love, I love no less than the great men, poets and painters and such like, who are on earth now; ... . Ah, do I not love them with

15. Partial models for the estimable women in these poems may be perhaps found in Morris's surprising remark years later that his early poems had been influenced by Elizabeth Barrett Browning. Perhaps he had in mind Browning's mournful and expressive heroines in "The Romaunt of the Page" and "The Romance of the Ganges."

16. AWS, 1:524; William Morris Archive, http://morrisedition.lib.uiowa.edu/earlypoems listandtexts.html\#4. 
just cause who certainly loved me, thinking of me sometimes between the strokes of the chisels. (349)

Similarly elegiac associations also appeared in "The Banners," which, like "The Abbey and the Palace," described a once noble ruin: "Long ago the roof fell in / . . A Archless stand the broken pillars tall." Only the former banners of the hall recorded shards of its history, but these too are transient:

Many tales the banners told

Of the gallant deeds of old;

But that wind within the tree

Wondrous stories telleth he:

$\mathrm{O}$ ! the banners told of love,

Now the wind is light above,

And he cometh from the Sea

Singing well of what shall be.

But the banners rot below

And the story of the banners no man shall ever know. ${ }^{17}$ (st. 3)

A sense of loss likewise appeared in "The Night-Walk," another of his unpublished poems, which, like "The Willow and the Red Cliff" or Wordsworth's “The Thorn," presented a deserted and passionately suffering woman. Morris's speaker is appalled by her desperate loneliness and isolation in "the Great Wen":

Night lay upon the city

Dull clouds upon the night

O! London without pity!

O! ghastly flaring light. ...

It fell on hungry faces

Thin lips, despairing frown,

Truly a dismal place is

That grim, gold-paved town. ... ${ }^{18}$ (sts. 1,4$)$

Oppressed by "fearful, dusky houses / [Which] hemmed me in alway," the

17. AWS, 1:531; http://morrisedition.lib.uiowa.edu/earlypoemslistandtexts.html\#6.

18. AWS, 1:525, poem is on pp. 525-29; William Morris Archive, http://morrisedition.lib. uiowa.edu/earlypoemslistandtexts.html\#5. 
unnamed woman clings to a "golden ring", a gift perhaps from someone in her past or evidence of former false hopes, and returns to die in her rural country home:

Her teeth were clenched together,

Her lips a little apart;

As she went in the doleful weather

Her breath did tear her heart. ...

She walks on, dreaming, dreaming...

She thinks not of the hours

The weary hours of woe

But looking at the flowers

She thinks it long ago.

There is an old, old garden,

She cometh to it soon;

An old, old house is its warden

In the sun and in the moon. (sts. 10, 22, 24, 25)

Despair and travail in the heedless city was a common theme in the literature and art of the period (cf. D. G. Rossetti's "Found"), and traces of Romantic and Pre-Raphaelite imagery appeared in Morris's devoutly painterly depiction of her death and (secular) transfiguration:

The rising sun is bringing

Lost love, and death anear.

The light shows through the windows

The roses hang across

O! The long deserted window!

Red roses hang across....

I think the leaves will bury her,

The snowy lilies look on her,

They look as if they love her,

The bee will look as he goes by,

The sun will look when he is high;

No sound will ever move her. 
In "Drowned" the last of the early poems May Morris printed in Artist, Writer, Socialist, a moment of near-death detachment enables a drowning man to regard with wonderment what he (still) can see:

What is the bottom of the river like?

$\mathrm{O}$ ! green it is with swinging weeds,

O! yellow with bright gravel,

$\mathrm{O}$ ! blue with the water overhead,

Through which the pike does travel,

Tenderly poised is the yellow-eyed pike.

I said "the water overhead"

For I lie here a-dying,

The pike looks down on my weedy bed,

How sweet it is to be dying! $!^{19}$

There is a sense in which the drowning man's situation-which may have been unique in nineteenth-century British poetry-was a relatively benign counterpart of other predicaments that oppressed Morris's protagonists. As I mentioned earlier, Morris suffered throughout his life from "rages"-probably epileptic syncopes or seizures-but also more benign auras in which he felt an epiphanic counterpart of Freud's "ozeanisches Gefühl."

As for the "Great Wen," Morris's later remarks to working-class auditors that London and other great cities were "masses of sordidness, filth and squalor" ${ }^{20}$ were not rhetorical flourishes, for their environments represented to him an utter estrangement from love and fellowship. The minute beauties of submerged flora and fauna and their soothing colors ("O! yellow with bright gravel"; "yellow-eyed pike") seemed to him by comparison gentle poetic emblems of death and (literal) subsumption into nature.

Among the seven early verses in Emma Oldham's drawer that May Morris chose not to publish, I will consider "The Ruined Castle" and "The Three Flowers," quatrain narratives in the manner of "Fame," and two fragments, "From All Other Ruined Shadows" and "And Then As the Ship Moves Over the Deep." ${ }^{21}$

"The Ruined Castle" superimposed two Morrisian objects of contemplation-a building in ruins, and an isolated woman in extremis - and the clarity

19. AWS, 1:531-32; William Morris Archive, http://morrisedition.lib.uiowa.edu/earlypoems listandtexts.html\#7.

20. "Art Under Plutocracy," 1883, CW, 23:170.

21. For the originals, see B. L. Ms. 45,298A, reproduced in the William Morris Archive, accessible from the portal for "Morris's Early Poems," or at http://morrisedition.lib.uiowa.edu/ images/BL-45298A/pageflip51-10o.html. 


\section{Som Ornoned.}

What is the bo then of the riaes tine?

O.' Preen it is woth swing ing weeds, olyellow with bifat gravel.

O!' Guwe with the whler over tead. Duroufh Which the hite doen trach, Seuderly foried is the yellowiered fithe.

I sid 'the wreer overhear' For 7 hie here a-dying,

- The fike lootho down onm movedy bed,

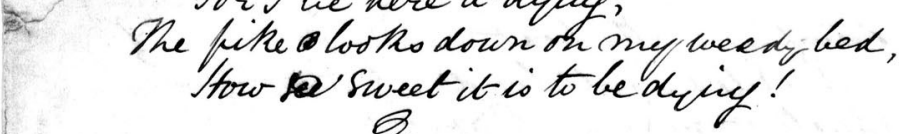

Orown, down, dower wer down the sines.

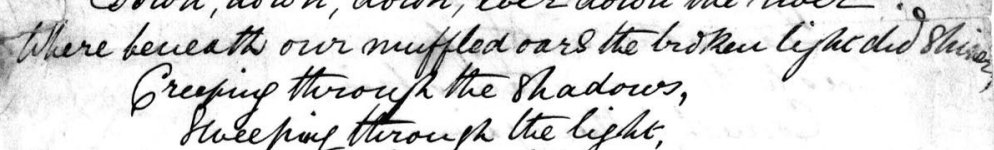

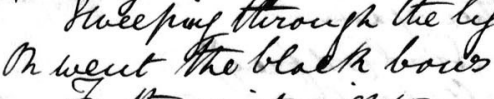
In the quict night:

Came we to the triver, Close up to the wall ,

In the midnipht how Errin it looked, and tate.

Into the fillew moat, An the water.gate anidots suefe the boat - Shere suy frow did wait

FIGURE 11. Autograph MS. of early poem, "Drowned," BL 45, 298A, folio 45. William Morris Archive. 
and immediacy of its lines would have graced The Defence, not to mention Oscar Wilde's "Ballad of Reading Gaol”:

The ancients surely were fools thought I

When they talked of the huntress moon,

I think she screams for she dwells in the sky

Both day and night alone: ... (st. 2)

But the brazen vane on the turreted stair

That faced the steady west wind,

It seemed to love the moon so drear

In the moonlight it looked kind-... (st. 5)

For bright by times, and dull by times

Did the yearning moon look on her.... (st. 7)

In boyhood Morris had been very fond of The Old English Baron, a narrative in which a pregnant mother and former lady of the castle flees into the winter night after she learns that her husband has been murdered by its new lord, gives birth to her child by a nearby river, and drowns herself. ${ }^{22}$ Heavily gothic in tone and imagery, "A Ruined Castle" portrays a lovelorn woman who wanders into a deserted castle by night. A former owner of the castle has murdered his wife and buried her under the stairs, after the manner of a gothic villain in the works of Clara Reeve, Horace Walpole, or Edgar Allan Poe, and the affronted building oozes blood one night each year from its floors and walls. In despair and horror, the desperate visitant falls into a protective trance:

Then the dismal tale, and the lady's thought,

In her brain a strange whirl wound,

Owl, vane and wind strange dreaming wrought,

On the leaves she lay in a swound. (st. 18)

The anguish and entrapment that recurred in Morris's work was often attended by a sudden need for deep sleep ${ }^{23}$ — another 'epileptic' analogy — and the deserted woman's mental anguish is softened in extremis by a near-death vision of universal love:

22. Clara Reeve, The Old English Baron: A Gothic Tale (London: 1770).

23. Jehane in The Defence, for example, falls into such a trance an hour before her refusal to become Godmar's mistress precipitates her lover's death. 
Through the fall of her golden, shining hair

She could see a face above her;

Two eyes shone moist in the morning air,

Truly they seemed to love her. ... (st. 20)

Unfortunately, the poem breaks off at this point, unlike its visionary counterpart in "Sir Galahad: A Christmas Mystery."

A measure of critical attention has been bestowed on "The Three Flowers," whose plot-in which a speaker is bereft when a beloved woman marries another man-has, as we have seen, been interpreted by John Le Bourgeois and Jack Lindsay as a sublimation of the adolescent Morris's response to the marriage of his sister Emma and Joseph Oldham. ${ }^{24}$ Equally salient may be the poem's use of flowers as emblems of human yearning and experience, and its idiosyncratic homage to anthropomorphic lilies and antheomorphic lovers.

The narrator of "The Three Flowers," in particular, likens himself to a solitary yellow daffodil in a garden in which the other flowers are paired:

Tiger lilies, tall white lilies,

In the summer grow together;

Gorgeous golden daffodillies

In the spring grow lonely ever. ${ }^{25}$ (st. 5)

The poem's (human) speaker remembers that the loved woman had attempted to comfort him with the memory of a childhood incident in which they had crowned each other with lilies and daffodils in a foretaste of shared heaven. Now she and her chosen "lily" have died, however, leaving him even more desolate:

There they lay, lay dead together

With their hands clasped each in each....

Round her head a crown of lilies

And a lily in her hand;

24. Lindsay, William Morris, 29-33; Le Bourgeois, Art and Forbidden Fruit, 11, diss. 15-20.

25. William Morris Archive, http://morrisedition.lib.uiowa.edu/earlypoemslistandtexts. html\#9; B. L. 45,298A, ff. 30-31. Both Lindsay and Le Bourgeois transcribe this last line above as "In the spring grow lovely ever," but the second-to-last word seems in fact to be "lonely," which in this context would be more pointed. Lindsay remarks that "the anger, driven down, comes out in the fantasy that both intruder and girl die" (William Morris, 37); still, one should not dismiss as insignificant Morris's projected wish for phantasmal reconciliation rather than displacement or revenge. 
Fair white lilies; tiger lilies

Round his head and in his hand. (sts. 21, 22)

Similarly, in the unfinished fragment, "From All Other Moving Shadows," a knightly narrator responds to an unidentified emotional shock:

Now the west was all ablaze with the sun,

There were purple clouds in the blaze:

The colours kept changing; the sun going down

And the east was soft with haze

... he gazed at the letter still

With his hand on the maple tree,

Till the sun was hidden by the hill

And he scarce could the letter see. . . ${ }^{26}($ st. 7,8$)$

Then the knight from the letter lifted his eyes

And he looked down on the river .... (st. 9)

Once again comfort comes in acceptance of the embrace of nature as consolation for human-centered loss (as conveyed in "the letter").

In a less static and more promising poetic fragment, "And Then As The Ship Moves Over The Deep," a peaceful sea voyage ends in disaster, and the lone and badly shaken survivor wanders a "dreary desert isle," bereft of the consolation and companionship Greek "elders" would later offer shipwrecked Nordic "wanderers" in the "Prologue" of Morris's Earthly Paradise.

\section{Phe temple and the mosque}

The longest and most substantive of Morris's early poems was "The Mosque Rising in the Place of the Temple of Solomon," sections of which appeared in May Morris's Artist, Writer, Socialist. ${ }^{27}$ She suggested that "The Mosque

26. See Boos, The Juvenilia of William Morris, and a corrected version of the Juvenilia text in the William Morris Archive, http://morrisedition.lib.uiowa.edu/earlypoemslistandtexts. html\#11. Since the draft appears to be in Emma Morris's hand, the indention of the original remains uncertain.

27. AWS, 1:377-82; William Whitla, "William Morris's 'The Mosque Rising in the Place of the Temple of Solomon': A Critical Text.” 
Rising" may have expressed Morris's brief affinity with the Oxford Movement in his first year at university, ${ }^{28}$ but I find it a remarkably secular poem, which quietly rejected the Movement's orthodox piety and Christian chauvinism and pilloried the violence and hypocrisy of the destroyers and would-be "restorers" of the temple of Jerusalem.

Written in blank verse, a form Morris almost never used in his later work, "The Rising of the Mosque" was offered for the Newdigate Prize competition at Oxford in 1855, as William Whitla has demonstrated. ${ }^{29}$ The competition's judges clearly anticipated and expected to reward an orthodox account of the relevant Christian and pre-Christian history. ${ }^{30}$

And so it came to pass. Edward Haydon Osborn carried off the prize for this topic with 309 lines of blank verse in which the poet-narrator envisions a second coming of Christ that would usher in "peace and brotherhood" and is reminded that in the meantime "thou hast God's work to do." Robert William Henderson took second place with 268 lines of heroic couplets that called for the conversion of the Jews, and interpreted the temple's destruction as a punishment for Jewish rejection of Christ ("Then fall, thou Mosque! Then Temple, spring from earth, / And let the shout of worlds announce thy second birth!”). ${ }^{31}$

Morris, by contrast, clearly welcomed the chance to contemplate the rise and fall of a nobler lieu de culte-a more mature counterpart of "The Banners," as it were. He showed little interest in the particular nature of this culte, but recalled a moment of grief and remorse in which

[David] lay praying, thinking of the flowers

That grow about the hills of Bethlehem. (11. 52-53),

and paused to evoke the later-ruined temple itself, in a pastoral image of

[t]he wild winds [which] threshed the charred cedar beams

As erst the tread of oxen threshed the grain.

Where once the incense stirred the purple veil

With its low breathing, now the wind bent down

The green grass waving o'er the Holy place. (11. 101-5)

28. AWS, 1:382.

29. Whitla, “The Mosque Rising,” 43.

30. Somewhat more precisely: “The Mosque Rising” narrated the building of Solomon's temple, the Babylonian invasion in the fifth century $\mathrm{BC}$, the building of the second temple, the destruction of this new temple in $\mathrm{AD} 70$, the Crusades, and a later conquest of Jerusalem by the Turks.

31. Whitla, “'The Mosque Rising,” 50-52. 
He did take care to describe the concrete details of (alleged) supernatural interventions, as when he evoked the strong winds and cinematic special effects that attended an angel's visit to Araunah's threshing floor: $3^{2}$

For ne'er before upon that threshing floor

Had such a wind blown the small straws about

As that, which blowing from the fiery wings,

Raised the curls up upon his snow-white brow

And let them fall again, as the lull came

Which the great wings swept back, or for awhile

Rested, an arch of light above his head

Of light that scorched not; (11. 25-32)

Morris depicted Jesus as an elusive presence-in the manger, on one of the three crosses outlined against the night sky, and in the sepulcher after the crucifixion-in lambent images presumably intended to evoke striking associations of liminal events without evoking supernatural interpretations.

In more poignant and literal images, he also described the influx of humble folk who came to express their love and gratitude at the burial site of a great healer: ${ }^{33}$

From far off lands both men and women come,

Strong men and weak, and women very weak

That they may lie upon that blessed stone

Where lay the pierced body of the Lord,

That they may die upon it, kissing it; . . . ${ }^{34}$ (11. 132-36)

\section{Compare Guenevere's plea in The Defence:}

Moreover, Christ, I cannot bear that hell, / I am most fain to love you. ... , Speak to me, Christ! I kiss, kiss, kiss your feet ("King Arthur's Tomb," 11. $178-79,181)$,

\section{or Lady Alice’s appeal in "Sir Peter Harpdon's End":}

32. Note that it is nonetheless an angel, not a divinity, who intervenes.

33. Compare the lines from "King Arthur's Tomb": "I shall go mad / Or else die kissing him, he is so pale, ..." (1l. 361-62), but in this instance "him" refers to the living Lancelot, not the dead Arthur, though Lancelot is weak and about to swoon from shock and grief.

34. See Edward Gibbon's account of the pilgrims at the Holy Sepulcher in The History of the Decline and Fall of the Roman Empire, 533; Gibbon mentions the fervor of both men and women pilgrims, "who professed their contempt of life, so soon as they should have kissed the tomb of the Redeemer." 
O Christ, that I may clasp your knees and pray, ...

Let us go, You and I, a long way off,

To the little damp, dark, Poitevin church;

While you sit on the coffin in the dark,

Will I lie down, my face on the bare stone

Between your feet...

Until you love me well enough to speak,

And give me comfort; yea, till ... I die,

Kissed over by you. (11. 662, 668-72, 676, 679-80)

The absence in "The Rising" of more orthodox Christian verities and its agnostic phenomenology of death were especially striking, given the nature of the assigned topic, the poem's ostensible theology, and Morris's nominal status as a prospective clergyman:

The warriors who lay dreaming on the hills

Lie dreaming now within their quiet graves

Or seem to dream, for there the white bones lie

With nothing moving them .... (1l. 171-74)

The absence in these suspensive lines of any tonic chord of resurrection adumbrated Morris's acceptance-expressed more explicitly in The Earthly Paradise-of the finality of death.

Even more strikingly for a poem largely centered on the Crusades, "The Rising" failed to celebrate the Crusaders' conquests as triumphs. Instead, the poem's allusions to war and its atrocities were forceful and blunt:

Ah me! they slew the woman and the babe

They slew the old man with his hoary hair,

The youth who asked not mercy, and the child

Who prayèd sore that he might see the sun

Some few days more-those soldiers of the cross.

Pray Christians for the sins of Christian men. (ll. 276-81)

These lines almost certainly affronted the poem's judges, who were probably unaware of their likely source, Henry Hart Milman's History of Latin Christianity, which Morris is known to have read during his time at Oxford: ${ }^{35}$

35. History of Latin Christianity, vol. 3, bk. 7, chap. 6, pp. 238-39, "Incidents of the Crusades." As noted in chapter 1, Morris's reading of this work would not have been a light task, since Milman's history is nearly 3,000 pages long. 
No barbarians, no infidel, no Saracen, ever perpetuated such wanton and cold-blooded atrocities of cruelty as the wearers of the Cross of Christ ... on the capture of that city. Murder was mercy, rape tenderness, simple plunder the mere assertion of the conqueror's right. Children were seized by their legs, some of them plucked from their mother's breasts and dashed against the walls, or whirled from the battlements. Others were obliged to leap from the walls, some tortured, roasted by slow fires. They ripped up prisoners to see if they had swallowed gold. Of 70,000 Saracens there were not left enough to bury the dead: poor Christians were hired to perform the office. Every one surprised in the Temple was slaughtered, till the reek from the dead bodies drove away the slayers. The Jews were burned alive in their synagogue. Even the day after, all who had taken refuge on the roofs ... were hewn to pieces; still later the few Saracens who had escaped, not excepting babes of a year old, were put to death. ${ }^{36}$

Morris knew well that a poetic counterpart of this damning passage would not find favor, but he submitted the poem anyway. So clearly did the lines quoted above endorse the views of revisionist medieval historians and anticipate his later opposition to the hypocrisies of British imperialism that its submission seems an act of protest as well as token of his abilities.

Less ideologically, "The Rising of the Mosque" also offered him a chance to express his growing interest in a Scandinavian "true north strong and free." Certain aspects of the poem's celebration of alleged Gothic virtues probably reflected his reading of Ruskin, ${ }^{37}$ and its landscape descriptions of boreal hills, trees, and flowers were noticeably incongruent in a poem focused on the 'Holy Land':

I cannot love thee South, for all thy sun,

For all thy scarlet flowers or thy palms;

But in the north for ever dwells my heart.

The north with all its human sympathies,

The glorious North, where all amidst the sleet

36. Milman's account follows that of Edward Gibbon, The History of the Decline and Fall of Rome, vol. 5, chap. 53, AD 1099. I am indebted to the late Joseph Dunlap for pointing out to me the relation between this episode and the accounts of Gibbon and Milman.

37. The Stones of Venice had appeared in 1851-53. In a passage from Morris's favorite chapter, "The Nature of Gothic" (vol. 2), Ruskin compares the characteristics of Northern architecture with that of Mediterranean countries: "it is true, greatly and deeply true, that the architecture of the North is rude and wild; but it is not true, that, for this reason, we are to condemn it, or despise. Far otherwise: I believe it is in this very character that it deserves our profoundest reverence" (The Genius of John Ruskin, ed. John Rosenberg [London: George Allen, 1963], 172). 
Warm hearts do dwell, warm hearts sing out with joy.

The North that ever loves the poet well,

The North where in the spring the primrose lies

So thick amongst the moss and hazel roots;

The North, where all the purple clouds do course

From out the north-west making green the trees;

Shout for the North, O! brothers shout with me,

Pray for the North, O brothers pray with me. (11. 205-17)

The obvious irrelevance of this passage in an elegy for a doomed Palestinian temple clearly anticipated Morris's active interest in Icelandic geography, saga-writings, and aspirations to democracy.

The final passages of the poem offered an elegiac appreciation of the temple's venerable past and Ruskin's "stain of time." ${ }^{8}$ Unlike those of the successful prize entrants, Morris's conclusion neither called for nor anticipated any form of Christian restoration:

When will the cross once more

Be lifted high above its central Home?

Never perhaps. Yet many wondrous things

That silent dome has looked on quietly. ...

I wonder what Araunah's floor was like

Before the flood came down upon the Earth. (11. 293-96, 299-300)

Only the simple threshing floor of the antediluvian world retains its capacity to evoke wonder. Morris's distaste for the idolatry of religiously justified violence suggested that he was already skeptical of wars of conquest disguised as wars of 'liberation,' and all the poem's other attributes-its secularism, its distaste for hypocrisy, its compassion for the sorrows of ordinary people, and its sense that buildings and structures are haunted by those who dwelt in them-would reappear in his contributions to The Oxford and Cambridge Magazine in 1856.

\section{Morris's first published verse}

When Morris and his friends and 'Brothers' founded The Oxford and Cambridge Magazine in 1856, they were animated by a desire-in Burne-Jones's

38. Ruskin, “The Lamp of Memory”, in Rosenberg, ed., Genius of John Ruskin, 133. 
dramatic formulation - to "mount a crusade and Holy Warfare against the age." ${ }^{39}$ If such aims were largely unfulfilled, the Magazine's happy few brought out seven-hundred-seventy-six dense pages of original tales, verse, and critiques of contemporary art, poetry, history, and philosophy in a single year. Morris, its first editor and financial supporter, helped swell this progress, and I consider his reviews and prose romances in chapters 4 and 5 .

Morris was also one of the Magazine's four contributing poets-along with Georgiana Macdonald, Dante Gabriel Rossetti, and William Fulford (the periodical's most faithful poetic contributor). Poetry graced less than 5 percent of the Magazine's pages, but most of it was good and some of it was memorable (a version of "The Burden of Nineveh," for example). All of it represented in various ways the reformist, nontheological, and experimental ideals that animated its founders.

In the five poems and three interspersed lyrics he published in The Oxford and Cambridge Magazine, Morris honed his style, experimented with prototypes of The Defence, and refined the oral qualities of his lyrics and dramatic narratives, developed through reading aloud to his friends and fellow contributors. ${ }^{40} \mathrm{He}$ later included an interpolated song ("In Prison") as well as four of his five Oxford and Cambridge Magazine poems in The Defence of Guenevere, and their dramatic and allusive style marked a shift from the quatrain-narratives he had drafted as an undergraduate. Moreover, Morris's poetic skills improved noticeably in the Magazine's brief life, and he must have felt encouraged by the results, for he turned next to preparing a volume of poetry.

"Winter Weather," Morris's contribution to the Magazine's first issue and the only poem he did not include in The Defence, was a revision of "The Midnight Tilt," a draft of which survives as an autograph manuscript in the British Library. ${ }^{41}$ The modified text-which derived its ambiance in part from

39. Burne-Jones, Memorials, 1:84. The context is a letter to Cormell Price of August 1853 in mock-elevated style, signed by "Edouard, Cardinal de Birmingham, O. J.": "We must enlist you, dear brother, in this crusade and Holy Warfare against the age, 'the heartless coldness of the times." (an echo of "In Memoriam," st. 106, "the faithless coldness of the times"). BurneJones here refers to the formation of a Brotherhood rather than to the Magazine in particular.

40. Valentine Prinsep recalled that when in 1857 he visited Rossetti and Burne-Jones in Oxford during the "Jovial Campaign," Rossetti invited Morris to read his poems to Prinsep, for "they are devilish good," and Morris read "in a kind of melodious growl with a considerable sing-song" (“Chapter from a Painter's Reminiscence," part 1, 168). The poems he read were both to appear in the 1858 Defence of Guenevere.

41. Oxford and Cambridge Magazine, January, 63-64. As with the other youthful poems, copies may have survived because Emma had kept them; for texts and publication information, see William Morris Archive, http://morrisedition.lib.uiowa.edu/earlypoemslistandtexts. html\#16. 
Malory, Froissart, and other sources Morris had studied at Oxford-carried over two stanzas from “The Midnight Tilt," and refined the latter's aabccb rhyme scheme and alternations of lines, words, sounds, and colors: ${ }^{42}$

We rode together

In the winter weather

To the broad mead under the hill;

Though the skies did shiver

With the cold, the river

Ran, and was never still. (st. 1)

Two rode beside me,

My banner did hide me,

As it droopd adown from my lance;

With its deep blue trapping,

The mail over-lapping,

My gallant horse did prance. (st. 3)

Two rode beside him,

His banner did hide him,

As it droop'd down strait from his lance;

With its blood-red trapping,

The mail over-lapping,

His mighty horse did prance. (st. 6)

The poem's details are emblematic: the speaker's colors are the dark blue of truth, his opponent's the "blood-red" of war, and his horse is "gallant," unlike the "mighty" steed of his better-equipped opponent. The occasion of the battle is abstract ("A false tale made he / Of my true, true lady") and the speaker is victorious, unlike most of his later counterparts in The Defence, but the imagery remains bleak and cold. After the encounter, the three survivors ride quietly home:

We rode back together

In the winter weather

From the broad mead under the hill;

No cloud did darken

42. The new stanzas added to "The Midnight Tilt" version delay the action by describing the opponent and his defeat. 
The night; we did hearken

How the hound bay'd from the hill. (st. 15)

The poem's austere conclusion-no female praise and no external recognition-was a characteristic of Morris's early poetry, as was its stark minimalism and suspensive absence of a clear wider context.

Another representation of conflict within a medieval setting, the May poem "Riding Together" manifests a progression in specificity and symbolism over January's “Winter Weather." Like the latter, "Riding Together” derived from an earlier draft, entitled "The Captive" in B. L. MS. 45,298A. ${ }^{43}$ Margaret Lourie has observed that its likely source was a passage in Jean de Joinville's Life of St. Louis, ${ }^{44}$ recounting an episode in which de Joinville had been taken prisoner after attempting to defend a bridge during the Battle of Mansura in Egypt. Morris's enactment centered on a violently defended fellowship and the violation of the peace of nature:

Up the sweep of the bridge we dash'd together,

It rock'd to the crash of the meeting spears,

Down rain'd the buds of the dear spring weather,

The elm-tree flowers fell like tears. (st. 8)

Morris's revisions heightened the poem's clarity, narrative precision, and psychological drama: The tenth stanza of the early draft had read:

I and the slayer met together,

O! vainly, vainly reined he back,

As he caught my eye in the clear, bright weather,

Shout, for his fixed eyes, and hold so slack.

In "Riding Together" this becomes, more dramatically:

I and the slayer met together,

He waited the death-stroke there in his place,

43. See William Morris Archive, http://morrisedition.lib.uiowa.edu/earlypoemslistandtexts.html\#55. Both the manuscript version, "The Captive," and "Riding Together" contained 13 stanzas; of these, sts. 1-6, 9, 12, and 13 remained largely intact, but verbal improvements were made to sts. 7, 8, and 10, and 11 was rewritten for clarity. Margaret Lourie points out verbal resemblances between st. 9 and passages from Morris's 1855 poem "The Mosque Rising in Place of the Temple of Jerusalem" (The Defence of Guenevere and Other Poems, 166-68, 249-50).

44. The 1807 translation by Thomas Johnes had been reprinted in an 1848 volume of Chronicles of the Crusades. 
With thoughts of death, in the lovely weather,

Gapingly mazed at my madden'd face.

Morris also added a stanza to explain the fate of these crusading "brothers," who, like de Joinville's men, had drowned in the river beneath and near the bridge:

Madly I fought as we fought together;

In vain: the little Christian band

The pagans drown'd, as in stormy weather,

The river drowns low-lying land.

Morris's two short poems for The Oxford and Cambridge Magazine"Hands" in July and "Pray But One Prayer for Me" in October-exploited similar sound-patterns to evocative effect. In "Hands," for example, he employed refrain-patterns, tetrameter triplets, and a tersely repetitive rhyme-scheme (aab ccb ddb):

'Twixt the sunlight and the shade

Float up memories of my maid,

God, remember Guendolen! ....

Hands used to grip the sword-hilt hard,

Framed her face, while on the sward

Tears fell down from Guendolen.

Guendolen now speaks no word,

Hands fold round about the sword.

Now no more of Guendolen.

Only 'twixt the light and shade

Floating memories of my maid

Make me pray for Guendolen.

Morris later folded "Hands" into the happy ending of the Defence's "Rapunzel," but the tone of its original is detached and vaguely funereal. Why, for example, "now no more of Guendolen"? Is she a distant memory as he rides into battle? Is she dead? Is her "love" an elusive ideal? The poem's opening and closing stanzas leave all these possibilities open: 
'Twixt the sunlight and the shade

Float up memories of my maid,

God, remember Guendolen! . . (st. 1)

Only 'twixt the light and shade,

Floating memories of my maid

Make me pray for Guendolen. (st. 6)

Such conjurations of liminal realms and memories "twixt the light and shade" would recur again and again in the Defence of Guenevere.

"Pray But One Prayer for Me" was untitled in The Oxford and Cambridge Magazine, and the table of contents for the bound volume of the Magazine changes "Me" in the title to "Us." The sonnetlike pattern of its heavily assonantal rhymes is abab/cdecfdecf/ff, but its fourteen lines divide midway through the seventh line, and all lines except the fourth one are tetrameter.

Pray but one prayer for me twixt thy closed lips,

Think but one thought of me up in the stars.

The summer night waneth, the morning light slips,

Faint and grey 'twixt the leaves of the aspen, betwixt the cloud-bars,

That are patiently waiting there for the dawn:

Patient and colourless, though Heaven's gold

Waits to float through them along with the sun.

Far out in the meadows, above the young corn,

The heavy elms wait, and restless and cold

The uneasy wind rises; the roses are dim; ${ }^{45}$

Through the long twilight they pray for the dawn.

Round the lone house in the midst of the corn.

Speak but one word to me over the corn,

Over the tender, bow'd locks of the corn.

This short lyric raises several questions. Who speaks, and to whom? Is the poem addressed to a Blessed-Damozel figure "in the stars," a fellow human being enjoined to "[s]peak but one word to me over the corn, / Over the tender, bow'd locks of the corn", or an aeolian-harp-like spectral voice carried by the breeze-in analogy with the predawn wind in section 95 of "In Memoriam," for example-which

... gathering freshlier overhead,

Rock'd the full-foliaged elms, and swung

45. "Dim" in the tenth line was probably a misprint for "dun." 


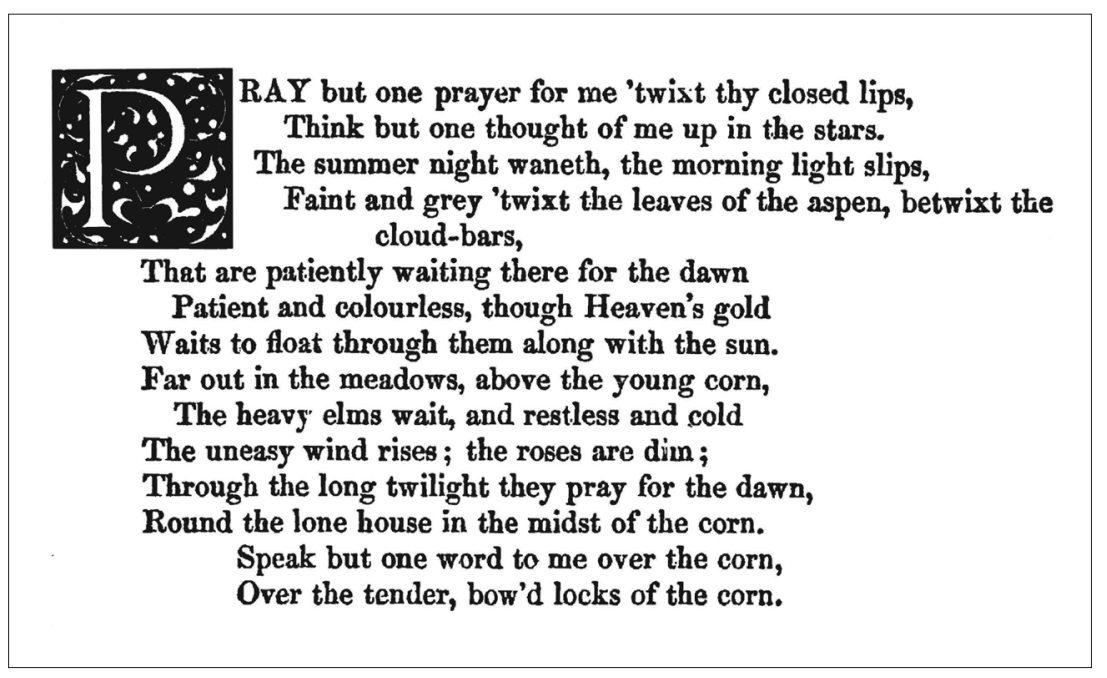

FIGURE 12. "Pray But One Prayer for Me," Oxford and Cambridge Magazine, October, page 644. William Morris Archive.

The heavy-folded rose, and flung

The lilies to and fro, and said

"The dawn, the dawn," and died away .... (sts. 15-16)

In her edition of The Defence of Guenevere, Margaret Lourie has suggested that Morris's poem (now titled "Summer Dawn") might be an English counterpart of a Provençal alba, "usually a daybreak dialogue between two lovers but in some later versions . . . addressed to the Virgin Mary. The only prosodic requirement for an alba is that each of its stanzas end with the word 'alba', which means 'dawn.' Note that Morris ends lines 5 and 11 (in the original version) with 'dawn.' 46

Whatever its provenance, the poem blends immanence ("Speak but one word to me over the corn") and transcendence ("Think but one thought of me up in the stars") in ways that blur imagination of fulfillment with a suffused sense of fulfillment itself.

The poem's sadness and beauty are intensified by its rhythms, which Lourie describes as four stressed anapests. As I read them, most of the lines are dactylic, in some cases with unvoiced nonstressed syllables at the end ("Pray but one prayer for me twixt thy closed lips || || / Think but one thought of me up in the stars \| \|"), interspersed with iambs and anapests ("That are

46. Margaret Lourie, http://morrisedition.lib.uiowa.edu/defencenotes.html\#summer. 
patiently waiting || || there for the dawn." . . "far out in the meadows, above the young corn"). Such caesurae and syncopations express moments of suspension and hesitation.

"The Chapel in Lyoness," an August poem and Morris's most carefully crafted contribution to The Oxford and Cambridge Magazine, became one of the Malorian poems that opened The Defence, along with "King Arthur's Tomb" and "Sir Galahad: A Christmas Mystery." Spoken in three voices and poised between lyric and narrative, "The Chapel” also prefigured later works in dramatic form such as "Sir Peter Harpdon's End," "Scenes from the Fall of Troy," and "The Lovers of Gudrun."

"The Chapel" was based on a Malorian tribute to the death of a faithful knight who had devoted his life to a search for the Holy Grail. Malory's Lyoness is a mythical realm since inundated by the sea, and its deserted chapel provides a fit setting for the lonely knight's death. In Morris's poem, Ozana, who in Malory had been portrayed as a brave but undistinguished knight, lies disoriented and fatally wounded, and the poem's two monologues are his last utterances. The poem's three personae, Galahad and his fellow knights Bors and Ozana, each speak twice, but never directly to each other, creating an eerie, surreal effect:

\section{Sir Ozana.}

All day long and every day,

From Christmas-Eve to Whit-Sunday,

Within that chapel-aisle I lay,

And no man came a-near. (st. 1)

Curtis Dahl has argued that Ozana's fasting and Galahad's bestowal of a rose and kiss signaled absolution for one who died in a state of grace, ${ }^{47}$ and what Ozana has "begun to fathom" is his redemption. Whatever the poem's iconographic resonances ${ }^{48}$ Ozana's fidelity to his fellows, the Grail quest, and a "golden tress" (presumably given him by a woman he has rescued) help him overcome the pain and confusion of his imminent death:

Sometimes strange thoughts pass through my head;

47. Curtis Dahl, "Morris's 'The Chapel in Lyoness': An Interpretation."

48. Morris prepared some revisions to the poem but decided after all to keep the original version. May Morris prints these emendations in $C W, 1: 12-13$. The unused revised version seems more polished and heightens Ozana's character as a visionary, but Morris may have wanted to keep the unsophisticated, naïve quality of the original. 
Not like a tomb is this my bed,

Yet oft I think that I am dead;

That round my tomb is writ,

"Ozana of the hardy heart,

Knight of the Table Round,

Pray for his soul, Lords, of your part;

A true knight he was found."

Ah! Me, I cannot fathom it. (He sleeps.) (sts. 7, 8)

At this point Galahad abruptly speaks. He has, it seems, been watching by his friend all along, and moreover has been singing a song Ozana cannot hear: "All my singing moved him not" (st. 10). Realizing that Ozana's death is impending, he leaves the chapel, bathes his face in a nearby purifying stream, and returns with a wild rose and water to place on his friend's face. At this sign of love and cleansing, Ozana then reveals his inmost desires: "He smiled, turn'd round toward the south, / Held up a golden tress" (st. 13). Ozana's last gesture is not prayer, then, as Galahad recognizes: "Against his heart that hair he prest; / Death him soon will bless" (st. 14).

At this point, Bors enters to pay his respects to the dying knight and touches him affectionately ("I laid my chin upon his head" [and] felt him smile; my eyes did swim, / I was so glad he was not dead"; st. 16). Soon thereafter, when Galahad kisses his brow, Ozana experiences relief ("I shiver with delight”), addresses his love: (“God move me to thee, dear, to-night!”; st. 18), and expresses gratitude that he no longer sees through a glass, darkly:

My life went wrong; I see it writ,

"Ozana of the hardy heart,

King of the Table Round,

Pray for his soul, lords, on your part;

A good knight he was found."

Now I begin to fathom it. (He dies.)

As he witnesses this, Bors looks at Galahad (not Ozana) and asks with genuine wonderment, "What strange things may his eyes see[?]"

As in "Winter Weather" and "Riding Together," "brotherhood" is an antechamber to an elusive form of sublimation that passes all understanding. As in "Hands" and to some extent "Pray But One Prayer," the shrouded mystery of a protagonist's life is revealed on the threshold of death, as Galahad observes in the poem's final lines: 
Ozana, shall I pray for thee?

Her cheek is laid to thine;

Her hair against the jasper sea

Wondrously doth shine. (st. 21)

Victorians admired this poem when Morris reprinted it in The Defence of Guenevere. Modern critics have preferred the intricate anguish of Guenevere and Lancelot in "The Defence" and "King Arthur's Tomb," but "The Chapel in Lyoness" remains an evocative work in its gently sublimated terms.

For its contributing poets, including Morris, it was unfortunate that the Oxford and Magazine ceased life at the end of 1856, and its subsequent obscurity has discouraged attention to its considerable role in Morris's early poetic evolution. Nonetheless, the access it offered to a wider poetic audience hastened the development of the mature narrative style and complex synthesis of eros and thanatos that emerged in The Defence of Guenevere.

As I remarked in the chapter's opening paragraphs, Morris's earliest poems have been written off as trivial, and he was well aware in later life that some of their lines were melodramatic. But they were not all slight, and their weight and inner consistency anticipated many aspects of his later work-The Defence, of course, but also the narrative poems of his middle period and the poems, essays, and political romances of his radical old age.

In these earliest poems, for example, Morris experimented with the direct presentation of experience through symbolic, emotion-laden landscapes and formulated his first literary responses to death, dreams, nature, betrayal, buildings, friendship, sexuality, religion, and geography, among other topics. Moreover, he assumed the burden of a lifelong preoccupation with the complexities of defeat and failure, braced himself to respond to them with protective sensitivity and insistent projections of faithful love, and tried to defend the stoic ideals he later expressed in a letter to his socialist comrade Bruce Glasier: "My life [has] been passed in being defeated; as surely every man's life must be who finds himself forced into a position of being a little ahead of the average in his aspirations." ${ }^{49}$ As he readied himself for these "defeats," he also prepared himself-secondarily, as it were-for the task of writing the intense and image-laden poetry of The Defence of Guenevere.

49. 15 August 1887, quoted in CW, 20:xlvii (and misdated as 1889), on the occasion of the capture of the Socialist League by its radical anarchist faction and the prospect that Commonweal might revert to becoming a monthly (which did not in fact happen until 1890). Kelvin, Letters, 3:684. 


\section{MORRIS'S EARLY ESSAYS}

n 1877 an art-manufacturer and nine of his associates and friends, mostly artists, ${ }^{1}$ gathered together in characteristic British fashion to establish a committee in opposition to what they viewed as one of the major evils of their time, the destruction of historic buildings in the name of "restoration." As the group's convener and Honorary Secretary, the then forty-two-year-old William Morris drafted the organization's "Manifesto for the Society for the Protection of Ancient Buildings," which firmly proclaimed the interrelations between a given historical period and its material culture:

The civilised world of the nineteenth century has no style of its own amidst its wide knowledge of the styles of other centuries. From this lack and this gain arose in men's minds the strange idea of the Restoration of ancient buildings; and a strange and most fatal idea, which by its very name implies

1. These were George Price Boyce, Alfred W. Hunt, Alfred Marks, Thomas Wilkinson Norwood, John Roddam Spencer Stanhope, F. G. Stephens, Henry Wallis, George Young Wardle, and Philip Webb. Webb was an architect; Wardle was a manager at Morris and Co; Boyce, Hunt, Stanhope, and Wallis were artists; and Stephens was an art critic and original member of the Pre-Raphaelite Brotherhood.

The Society is still active; its central office is at 37 Spital Square, London E1 6DY, and its website at http://www.spab.org.uk. 
that it is possible to strip from a building this, that, and the other part of its history - of its life that is - and then to stay the hand at some arbitrary point, and leave it still historical, living, and even as it once was.

The remoteness and fragility of the past, Morris asserted, called for honest recognition, not decorative restoration or generic nostalgia:

We pray [architects and the public] to remember how much is gone of the religion, thought and manners of time past, never by almost universal consent, to be Restored; and to consider whether it be possible to Restore those buildings, the living spirit of which, it cannot be too often repeated, was an inseparable part of that religion and thought, and those past manners ... in fine to treat our ancient buildings as monuments of a bygone art, created by bygone manners, that modern art cannot meddle with without destroying. ${ }^{2}$

In response to early criticisms of the fledgling Society for the Protection of Ancient Buildings as a group of medieval art fanatics, Morris returned to his charge the following year, and in his "Report" to the Society's first annual meeting he broadened its stated aim to include the protection of all genuinely artistic styles, modes, and periods:

The Society neither has the will nor the power to enter into any "battle of the styles"; and ... counts amongst its members persons ... differing widely in their artistic sympathies, whose common bond is earnest opposition at once to neglect and meddling in matters concerning all buildings that have any claim to be considered works of art. Our enemies are the enemies of the works of all styles alike, ignorant destruction and pedantic reconstruction. ${ }^{3}$

During the next decade, Morris began to develop a comprehensive view of art as he wielded the organization's pen and helped conduct its many early campaigns. In so doing, he broadened his early critique of the destructive effect of "competitive commerce" on the environment (in "The Lesser Arts" [1877]) to a more systematic indictment of the economic system that sustained and enforced such destruction, in such essays as "Misery and the Way Out" and "Monopoly, or How Labour Is Robbed."

In Hopes and Fears for Art (1882) and Signs of Change (1888) as well as a

2. "Manifesto, Society for the Protection of Ancient Buildings," in May Morris, William Morris: Artist, Writer, Socialist (1936, rpt. Russell and Russell, 1966), 1:111.

3. Society for the Protection of Ancient Buildings. The First Annual Meeting of the Society, Report of the Committee Thereat Read. 21st June, 1878. William Morris, Hon. Sec., 17. 
number of additional unpublished or posthumously published essays, ${ }^{4}$ Morris also extended the notion of "art" to include most purposeful and pleasurable human activities, attack the exploitation of human labor and organization of society for profit, and claim for each member of society a right to pleasure in labor and an equal share in the reward of his or her work.

Written or prepared for oral presentation to many disparate audiences, Morris's essays on art and socialism described in consistent and internally coherent ways the principles and practices of a democratic art he hoped would reflect the changed ideals of an equal and free society. Four recurrent ideals or regulative principles animated his thought:

- the importance of pleasure in labor;

- the need for simplicity (not privation) in a well-lived life;

- the role of craft and architecture as repositories of memory and history; and

- the conviction that humans must live in respectful harmony with the transcendent beauty of nature.

All these ideals and principles, I will argue, were adumbrated and prefigured to some degree in Morris's early writings, some more self-consciously than others.

Morris, like Marx and Carlyle, saw the human being as a worker, and more importantly, as an artisan or craft worker entitled to the pleasures of free creation. In the ironically titled "The Lesser Arts", for example-his first known public lecture-he proclaimed that "I scarcely know how to speak strongly enough" of "the giving us pleasure in our work." And in "Art and the Beauty of the Earth," four years later (1881), he remarked that

time was when everybody that made any thing made a work of art besides a useful piece of goods, and it gave them pleasure to make it. . . If I have any worthy aspiration, it is the hope that I may help to bring about the day when we shall be able to say, So it was once, so it is now.

Do not misunderstand me; I am not a mere praiser of past times. I know that in those days of which I speak life was often rough and evil enough, beset by violence, superstition, ignorance, slavery; yet I cannot help thinking

4. Architecture, Industry and Wealth (London: Longmans, Green, 1902) and William Morris: Artist, Writer, Socialist. See also Eugene LeMire, ed., The Unpublished Lectures of William Morris, "Appendix II: A Bibliographical Checklist of Morris's Speeches and Lectures."

5. LeMire, "Appendix II," no. 1, in Unpublished Lectures of William Morris; "The Lesser Arts," CW 22:5. 
that sorely as poor folks needed a solace, they did not altogether lack one, and that solace was pleasure in their work. ${ }^{6}$

This was a message he reiterated often, for example, in "The Arts and Crafts of Today" (1889):

If people were once to accept it as true, that it is nothing but just and fair that every man's work should have some hope and pleasure always present in it, they must try to bring the change about that would make it so: and all history tells of no greater change in man's life than that would be. ${ }^{7}$

This ideal — for it was, of course, a limiting ideal —was sustained by a concomitant belief in the significance of architecture and other decorative crafts as repositories of human memory and history. In this, Morris followed his early mentor John Ruskin, whose 1849 "Lamp of Memory" put the matter in literally 'luminous' terms as follows:

For indeed the greatest glory of a building is not in its stones, nor in its gold. Its glory is in its Age ... it is in that golden stain of time, that we are to look for the real light, and colour, and preciousness of architecture. ${ }^{8}$

To this, as we have seen, Morris added a radical-democratic inflection of his own:

Nor must you forget that when men say popes, kings, and emperors built such and such buildings, it is a mere way of speaking. You look in your history-books to see who built Westminster Abbey, who built St. Sophia at Constantinople, and they tell you Henry III, Justinian the Emperor. Did they? or, rather men like you and me, handicraftsmen who have left no names behind them, nothing but their work?"

6. "Art and the Beauty of the Earth," CW, 22:163. See also Morris's preface to "The Nature of Gothic," in AWS: "For the lesson which Ruskin here teaches us is that art is the expression of man's pleasure in labour" (292). A more extensive account of Morris's later views on art may be found in Florence Boos, "Everyday Life in Morris's News from Nowhere," in Literary Utopias of Cultural Communities, ed. Marguérite Corporaal and Evert Jan van Leeuwen (Amsterdam: Rhodopi, 2010), 141-70.

7. "The Prospects of Architecture in Civilisation," CW, 22:140.

8. John Ruskin, in Rosenberg, ed., The Genius of John Ruskin, 132-33.

9. "The Lesser Arts," CW, 22:6-7. 
Morris's early reading had inclined him toward a lifelong love of medieval history and architecture, but he realized that these insights and egalitarian ideals applied in principle to all periods, and all manner of personal, aesthetic and intellectual 'crafts.' This broader awareness enlarged his view of history to embrace all forms of spiritual as well as material culture, for "real history ... is no dead thing, but the living bond of the hopes of the past, the present, and the future."

Part of Morris's view of the inherent artfulness of human beings was his perception of their embeddedness in "nature," and the importance of preserving nature for its own sake and theirs. This ecological vision appeared in even his first published essay:

For your teachers, they must be Nature and History. . . .

Is money to be gathered? cut down the pleasant trees among the houses, pull down ancient and venerable buildings for the money that a few square yards of London dirt will fetch; blacken rivers, hide the sun and poison the air with smoke and worse, and it's nobody's business to see to it or mend it: that is all that modern commerce, the counting-house forgetful of the workshop, will do for us herein. ${ }^{11}$

Motivated perhaps by witnessing the even more rapacious forms of destruction in the north of England, which he canvassed on behalf of the Socialist League during the 188 os, Morris began to speak about a "society of the future," in which "the huge manufacturing towns will be broken up, and nature heal the horrible scars that man's heedless greed and stupid terror have made." 12

Shall I tell you what luxury has done for you in modern Europe? It has covered the merry green fields with the hovels of slaves, and blighted the flowers and trees with poisonous gases, and turned the rivers to sewers; till over many parts of Britain the common people have forgotten what a field or a flower is like. ${ }^{13}$

10. "The Origins of Ornamental Art" (1886), in Norman Kelvin, ed., William Morris on Art and Socialism, 167.

11. “The Lesser Arts," CW, 22:15, 24.

12. "The Society of the Future" (1887), in Kelvin, ed., Art and Socialism, 179.

13. Ibid., 177. In "The Beauty of Life," he attacks the hypocrisy of those who claim to love art while destroying nature: "these gentlemen, many of whom buy pictures and profess to care about art, burn a deal of coal: . . . nothing hinders these lovers of art . . from making it a point of honour with them to minimise the smoke nuisance as far as their own works are 
This sense of the interrelations between beauty in art and landscape and the earth itself formed a bridge to Morris's holistic and ecological perspective, as did its corollary: that the human capacity to embody the fundamental processes of nature was the basis of decorative or constructed art, and the due right of every person:

Now it is one of the chief uses of decoration, the chief part of its alliance with nature, that it has to sharpen our dulled senses in this matter: for this end are those wonders of intricate patterns interwoven, those strange forms invented, which men have so long delighted in: forms and intricacies that do not necessarily imitate nature, but in which the hand of the craftsman is guided to work in the way that she does, till the web, the cup, or the knife, look as natural, nay as lovely, as the green field, the river bank, or the mountain flint. ${ }^{14}$

Less self-evident for a decorative artist was Morris's commitment to "simplicity," which he interpreted as a concern for socially desirable essentials and acceptance of material equality. In "The Lesser Arts," he had already begun to adumbrate such an ideal, of

simplicity of life begetting simplicity of taste ... [which] is of all matters most necessary for the birth of the new and better art we crave ... ; simplicity everywhere, in the palace as well as in the cottage. ${ }^{15}$

Here Morris may use the term "simplicity" in a largely aesthetic sense, referring to the absence of pretentious or meretricious display. More mindful later perhaps of the inconsistency of advocating simplicity "in the palace as well as ... the cottage," Morris attacked "luxury" and the class system which it defined with an animus which divided him from most of his social peers:

Luxury . . . builds clubs in Pall Mall, and upholsters them as though for delicate invalid ladies, for the behoof of big whiskered men, [so] . . that the very plush-breeched flunkies that wait upon the loungers are better men than they are. I needn't go further than that: a grand club is the very representative of luxury. ${ }^{16}$

concerned; and if they don't do so, when mere money, and even a very little of that, is what it will cost them, I say that their love of art is a mere pretence" ( $C W, 22: 70-71)$.

14. "The Lesser Arts," CW, 22:5.

15. Ibid., 24 .

16. "The Society of the Future," in Kelvin, ed., Art and Socialism, 177-78. 
In "The Art of the People" Morris noted the parasitism necessary for the fulfillment of such artificial wants, in terms that clearly reflected his personal distaste for its products:

Luxury cannot exist without slavery of some kind or other, and its abolition will be blessed, like the abolition of other slaveries, by the freeing both of the slaves and of their masters. ${ }^{17}$

Indeed, our sacrifice on the side of luxury will, it seems to me, be little or nothing: for, as far as I can make out, what people usually mean by it, is either a gathering of possessions which are sheer vexations to the owner, or a chain of pompous circumstance, which checks and annoys the rich man at every step. ${ }^{18}$

"Luxury," of course, required human servants (the aforementioned "plushbreeched flunkies that wait upon the loungers"). In the "the society of the future,"

being determined to be free, and therefore contented with a life not only simpler but even rougher than the life of [wage-] slave owners, ... men (and women too, of course) would do their work and take pleasure in their own persons, and not vicariously. ${ }^{19}$

(What, I wonder, might Morris have thought of servomechanisms-constructed at enormous social, environmental and ergonomic cost-instead of servants?)

In summary: during the last thirty-odd years of his life, Morris articulated the period's most developed socially critical theory of 'popular' or 'democratic' art, and the political and social changes that might make it possible. It was an unceasing effort, and his last recorded speech, on January 31, 1896, was to a now-forgotten organization, the Society for Checking the Abuses of Public Advertising. In it, he proclaimed that the sight of a billboard or placard defacing the countryside never failed to evoke his revulsion: "It is horrible; I cannot look at it." ${ }^{20}$

\footnotetext{
17. "The Art of the People," $C W, 22: 48$.

18. Ibid.

19. "The Society of the Future," in Kelvin, ed., Art and Socialism, 183.

20. A Beautiful World, December 1896, 17.
} 


\section{USKIN}

The political implications of Morris's vision of the unity of artistic expression and its economic underpinnings were so 'radical' in the original sense of the word that it is natural to search for antecedents of them in his early life and environs. Can one discern anticipatory versions of these social and aesthetic views in his earliest poems, his friends' memories of his youthful opinions, or his criticism and other writings for The Oxford and Cambridge Magazine? Or did they arise more from his work as a craftsman and artmanufacturer, pressured to sacrifice his aesthetic ideals and the well-being of those who worked with him in the interest of greater profit and more "competitive commerce"?

As we have seen, one of the best sources for our limited knowledge of Morris as a youth is a sixteen-page handwritten memoir R. W. Dixon wrote for J. W. Mackail while the latter prepared his biography of Morris for publication in $1899 .{ }^{21}$ Dixon-who spent a great deal of time in his three years at Oxford in the company of Morris, Edward (Burne-)Jones, William Fulford, and other friends and later collaborators on The Oxford and Cambridge Magazine-remembered many innocent details, such as that Morris was "fond of going down to the river with Faulkner," for example, and "very fond of sailing a boat." ${ }^{22} \mathrm{He}$ also recalled

how many things he knew that were quite out of our way; as e. g. architecture. . . . His rooms were full of rubbings of brasses, which he had made: and he had the Arundel Society's reproductions; and many other precious things. ... So far as I remember, his observations of art began with architecture. He was constantly drawing windows, arches, and gables in his books. One of the first things he ever said to me was to ask me to go with him to look at Merton tower. He used to take the Builder, and read it, and sometimes talk of the plans and designs in it. Few undergraduates have done that. $^{23}$

Morris apparently read all of Ruskin's available writings as well: The Seven Lamps of Architecture, for example, which had appeared in 1849 when he was fifteen; The Stones of Venice (1851-53), published before and during his time at Oxford; and the Edinburgh Lectures with its praiseful essay on the Pre-

21. J. W. Mackail, Life; R. W. Dixon, "Memoir of William Morris," 19-24.

22. Dixon, "Memoir," 20.

23. Ibid. 
Raphaelites (1854). Georgiana Burne-Jones later recalled Edward's memory of an incident in the summer of 1854, when "I was working in my room [and] Morris ran in one morning bringing the newly published book with him: so everything was put aside until he read it all through to $m e$ " (italics mine), ${ }^{24}$ and Dixon wrote Cormell Price in September that Morris- "the 'little brick" had just sent him a copy of Ruskin's Seven Lamps. ${ }^{25}$

Morris's indebtedness to the man he called in "The Lesser Arts" "my friend Professor John Ruskin" was deep, formative, and well-acknowledged. Ruskin's name appears more often than that of any other individual in Morris's lectures, and there is a sense in which Morris de-'sacralized' sensibilities and modes of thought expressed more metaphorically in Ruskin's "Lamp of Memory":

It is as the centralisation and protectress of this sacred influence [of memory] that Architecture is to be regarded by us . . . How cold is all history, how lifeless all imagery, compared to that which the living nation writes, and the uncorrupted marble bears! . . there are but two strong conquerors of the forgetfulness of men, Poetry and Architecture; and the latter in some sort includes the former, and is mightier in its reality: it is well to have, not only what men have thought and felt, but what their hands have handled, and their strength wrought, and their eyes beheld, all the days of their life. ${ }^{26}$

In “The Lesser Arts," Morris enjoined upon his audience that Ruskin's "On the Nature of Gothic, and the Office of the Workman Therein" would give them "at once the truest and the most eloquent words that can possibly be said on the subject." ${ }^{27}$ Later, in 1892, "The Nature of Gothic" was one of very few nineteenth-century prose works Morris reprinted at the Kelmscott Press, and his preface for this edition predicted that "in future days [it] will be considered as one of the very few necessary and inevitable utterances of the century." In 1877, after Morris co-founded the Society for the Protection of Ancient Buildings, he wrote Ruskin solicitously for permission to use a passage from "The Lamp of Memory" in a Society leaflet: "[your words] are so good, and so completely settle the whole matter, that I feel ashamed at

24. Burne-Jones, Memorials, quoted in Nicholas Salmon with Derek Baker, William Morris Chronology, 9.

25. Salmon and Baker, William Morris Chronology, 13.

26. Ruskin, in Rosenberg, ed., Genius, 13. Other traits Morris shared with Ruskin were an interest in domestic architecture and an insistence that members of every generation consider the welfare of their descendants; cf. The Seven Lamps of Architecture, "The Lamp of Memory," in ibid., 132.

27. “The Lesser Arts," CW, 22:5. 
having to say anything else about it, as if the idea was an original one of mine, or any body's else but yours." ${ }^{28}$ It is not surprising that Morris's early writings on architecture showed particularly Ruskinian influences in their style and rhetorical turns as well as their content.

In 1899 the SPAB historian George Wardle estimated that half the 7,144 churches and cathedrals in England and Wales had been "restored" between 1840 and $1873,{ }^{29}$ and so the counterreaction of Ruskin and his historically and artistically inclined friends may in a sense have been inevitable. As early as 1824 , for example, Byron's narrator in Don Juan had satirized a "Gothic" architect

[w] ho, after rummaging the Abbey through thick

And thin, produced a plan whereby to erect

New buildings of correctest conformation,

And throw down old-which he called restoration. ${ }^{30}$

When Morris and his fellow students visited Northern France in 1855, they carried with them John Murray's Handbook for Travellers in France, ${ }^{31}$ which pointed out the "mutilations" and other forms of destruction in some of the churches they visited. Morris himself was sufficiently disturbed by what he had already seen of the "restorations" at Notre Dame Cathedral on a preceding trip that he suggested the group skip Paris altogether (advice which they ignored). Morris also chose to begin his training as a would-be architect with George Edmund Street, the author of Brick and Marble in the Middle Ages, ${ }^{32}$ and he revisited northern France with Street in the fall of 1856. Morris later came to disagree with some of the practices of Street's firm, but John Purkis has observed that Street and Morris nonetheless "shared similar tastes and liked the same churches." 33

As mentioned earlier, almost all of Morris's marked aesthetic preferences appeared in his earliest writings, among them a review and two essays for The Oxford and Cambridge Magazine, as well as "The Mosque Rising in the Place of the Temple of Solomon," which as we have seen was a notably heterodox

28. 10 July 1877 , Kelvin, Letters, 1:383.

29. Society for the Protection of Ancient Buildings, 14.

30. Canto 16, st. 58.

31. London: Murray, 1854 ed.

32. London, 1855 . He also published An Urgent Plea for the Revival of the True Principles of Architecture in the Public Buildings of the University of Oxford (Oxford and London, 1853), and Some Account of Gothic Architecture in Spain (London, 1865).

33. John Purkis, Morris, Burne-Jones and French Gothic, 24. 
poem whose secularism, distaste for hypocrisy, and concern for setting conveyed an almost-mystical sense that structures can offer redemptive shelter to those who inhabit them.

\section{" The greatest pleasure I have ever had"}

Morris crossed the channel many times during his life, ${ }^{34}$ but he recorded his reactions to a summer 1855 trip that he took with friends Fulford and Jones so well in letters to his mother and his friend Cormell Price that John Purkis is probably right that "we know more about this one day [July 27th, 1855] than [about] any other [day] in Morris's early life." 35

In view of Morris's later politics, it is noticeable that during their journey Morris, Burne-Jones, and Fulford paid little heed to the economic or social conditions of the places they visited, even though this was a period in which France and England were both at war in the Crimea. Instead, they concentrated entirely on visiting eight cathedrals, somewhere between eleven and twenty-four churches, and an indeterminate number of museums and exhibitions. ${ }^{36}$ As noted previously, Morris and Burne-Jones ended their artistic pilgrimage with a profession of aesthetic faith on the quays of Le Havre, in which they vowed to devote themselves to a life of art, rather than the religion they had been sent to Oxford to study.

The near-rhapsodic quality to parts of this journey was apparent in Morris's letter to his mother (“. . . we have had a glorious time of it, working desperately hard; my two friends have been in a state of ecstasy since we landed, and for the matter of that so have I," Sunday, 29 July), ${ }^{37}$ and more so in his long description to Cormell Price of the countryside between Chartres and Dreux, part of which was quoted in chapter 2:

I almost think I like that part of the country better than any other part of the lovely country we have seen in France; so gloriously the trees are grouped, all manner of trees, but more especially the graceful poplars and aspens,

34. Ibid., 26. Trips to northern France included a visit with his sister Henrietta in the summer of 1854, the well-known tour with friends in July and August 1855, a journey with G. E. Street in 1856, and seven more stays in the 1850 s and ' 60 s, not counting brief business trips. Purkis notes that May Morris also mentions a visit in 1866 with Warrington Taylor, though this is not otherwise documented.

35. Ibid., 10.

36. Ibid., 29-35.

37. 29 July 1855 , Kelvin, Letters, 1:17. 
of all kinds; and the hedgeless fields of grain, and beautiful herbs that they grow for forage . . . the most beautiful fields I ever saw yet, looking as if they belonged to no man, as if they were planted ... for their beauty only, that they might grow always among the trees, mingled with the flowers, purple thistles, and blue corn-flowers, and red poppies ... they all looked as they would grow there for ever, as if they had always grown there, without change of season, knowing no other time than the early August..$^{38}$

This was an epiphanic moment of near van-Gogh-like intensity, which anticipated the emotion-laden descriptions of floral landscapes in Morris's early prose romances, and evoked the eternity of the moment, the splendor of the cornflowers and the impossibility of their retention.

Morris recalled the journey often in his later lectures-in "The Aims of Art," for example:

Less than forty years ago-about thirty-I first saw the city of Rouen, then still in its outward aspect a piece of the Middle Ages: no words can tell you how its mingled beauty, history and romance took hold on me; I can only say that, looking back on my past life, I find it was the greatest pleasure I have ever had. ${ }^{39}$

Even more introspectively, he wrote to Georgiana Burne-Jones from a visit to Italy in 1878 that

I am more alive again, and really much excited at all I have seen and am seeing. . . . Many times I think of the first time I ever went abroad, and to Rouen, and what a wonder of glory that was to me when I first came upon the front of the Cathedral rising above the flower-market. It scarcely happens to me like that now, at least not with man's work, though whiles it does with bits of the great world, like the Garda Lake the other day, or unexpected sudden sights of the mountains. ${ }^{40}$

This was the inexpressible beauty, harmony, and complementarity between art and nature he strove to write about so often in later life, in his lectures, in News from Nowhere, and in his prose romances.

The three young men had left behind them at Oxford heated religious controversies, dominated by debates about the merits of ritualism, rapproche-

\footnotetext{
38. 10 August 1855, ibid., 20.

39. $C W, 23: 85$.

40. 16 May 1878, Kelvin, Letters, 1:486
} 
ment with Rome, and so forth. Nevertheless their memories of this period seem mostly devoid of piety, doctrine, or any other religion than that of art. As noted previously, Cormell Price had recorded in his diary for May 1855:

Our Monastery will come to nought, I'm afraid; Smith has changed his views to extreme latitudinarianism, Morris has become questionable on doctrinal points, and Ted is too Catholic to be ordained. ${ }^{41}$

Dixon, who later became Canon of Carlisle, recalled somewhat ruefully of this period that

Jones and Morris were both meant for Holy Orders, and the same may be said of the rest of us except Faulkner: But this could not be called the bond of alliance. We never spoke of it to one another: and I am sorry to say, for my own part, that it was not contemplated, or kept before the mind. The bond was poetry, and indefinite artistic and literary aspiration; but not of a . . self-seeking character. We all had the notion of doing great things for man: in our own way, however: according to our own will and bent. ${ }^{42}$

I have already commented on the markedly secular ethos of Morris's "The Rising of the Mosque in the Place of the Temple of Solomon." As mentioned in chapter 1 , the view that Christianity was of historical rather than contemporary importance ("a mere decent form to all the nations," ${ }^{43}$ he called it in his 1856 review of Robert Browning's Men and Women) remained with Morris throughout the rest of his life. In his draft of the SPAB manifesto, for example, he went out of his way to mark "how much is gone of the religion, thought and manners of the past, never by almost universal consent, to be restored" (italics mine), even though he knew this remark might offend clergymen and others to whom the Society had to address itself.

41. Salmon and Baker, William Morris Chronology, 10.

42. Dixon, "Memoir," 20.

43. Oxford and Cambridge Magazine, March 1856, 162. Cf. Morris's 6 October 1855 letter to Cormell Price: "I don't think even if I get through Greats that I shall take my B. A., because they won't allow you not to sign the 39 Articles unless you declare that you are 'extra Ecclesiam Anglicanam' which I'm not, and don't intend to be, and I won't sign the 39 Articles" (Kelvin, Letters, 1:23). In “The 'First' William Morris and the 39 Articles," Eugene LeMire explains that between the time of this letter and Morris's graduation the interpretation of the rules had been loosened so that Anglicans who refused to sign the 39 articles were permitted to receive degrees. See chapter 1 , note 9. 


\section{HE OXFORD AND CAMBRIDGE MAGAZINE}

All of these attitudes and convictions became strikingly evident in Morris's contributions to The Oxford and Cambridge Magazine, a literary and cultural monthly periodical called into a single year of life by Morris, Jones, Dixon, Price, William Fulford, Charles Faulkner, and Harry Macdonald (the brother of Georgiana Burne-Jones), along with Godfrey and Vernon Lushington and Wilfred Heeley (the Magazine's Cambridge wing). ${ }^{44}$ Morris was the magazine's editor during its first month, and he was responsible for the bordered design and ornamented initials of its cover, somewhat distinctive for a periodical of the time..$^{45} \mathrm{He}$ was also the periodical's chief contributoroften placing two or three stories, articles, or poems in a single issue ${ }^{46}$ - with a total of one review, two essays, five poems, and nine prose tales, three of which included an additional poem. Morris never sought to republish the tales or reviews in his lifetime, although as we have seen, four of the five poems reappeared in The Defence of Guenevere, with "Riding Together" condensed, "The Chapel in Lyoness" and "Summer Dawn" subjected to slight revision, and an inset lyric from "Frank's Sealed Letter" given the title "In Prison."

A reader of The Oxford and Cambridge Magazine in 1856 might have singled out certain contributors as potentially successful theorists or commentators of one sort or another: Godfrey Lushington, for example, who wrote a well-argued call for educational reform (“Oxford”); R. W. Dixon, who contributed two articles on the Near East ("The Barrier Kingdoms" and "The Prospects of Peace"); and Edward Burne-Jones, an ardent defender of Ruskin against his detractors ("Ruskin and the Quarterly"). ${ }^{47}$ These were impressive

44. Articles or poems were also contributed by Georgiana Macdonald (later Georgiana Burne-Jones), Bernard Cracroft, Lewis Campbell, Robert Campbell, W. Aldis Wright, and Dante G. Rossetti.

45. Walter K. Gordon, "A Critical Selected Edition of William Morris's 'Oxford and Cambridge Magazine' (1856)," 23, 30-31.

46. Issues were either 64 or 72 pages. Morris contributed nineteen items in all: three items to the August and September issues; two to January, February, March, July, and October; and one each to April, May, and December.

47. Assorted sentences and stylistic mannerisms in "Ruskin and the Quarterly" resemble locutions in Morris's other contributions, and according to Gordon the article was formerly thought to be by Morris. In The Hollow Land and Other Contributions to the Oxford and Cambridge Magazine, however, Eugene LeMire attributed this ascription to the forger H. Buxton Forman, and Ruskin's editor E. T. Cook reported Mackail's view that "while representing the opinions of both Morris and Burne-Jones, it was for the most part written by the latter" (LeMire, Hollow Land, xx). See Florence Boos, "Attributions of Authorship in the Oxford and Cambridge Magazine," 562-63. 


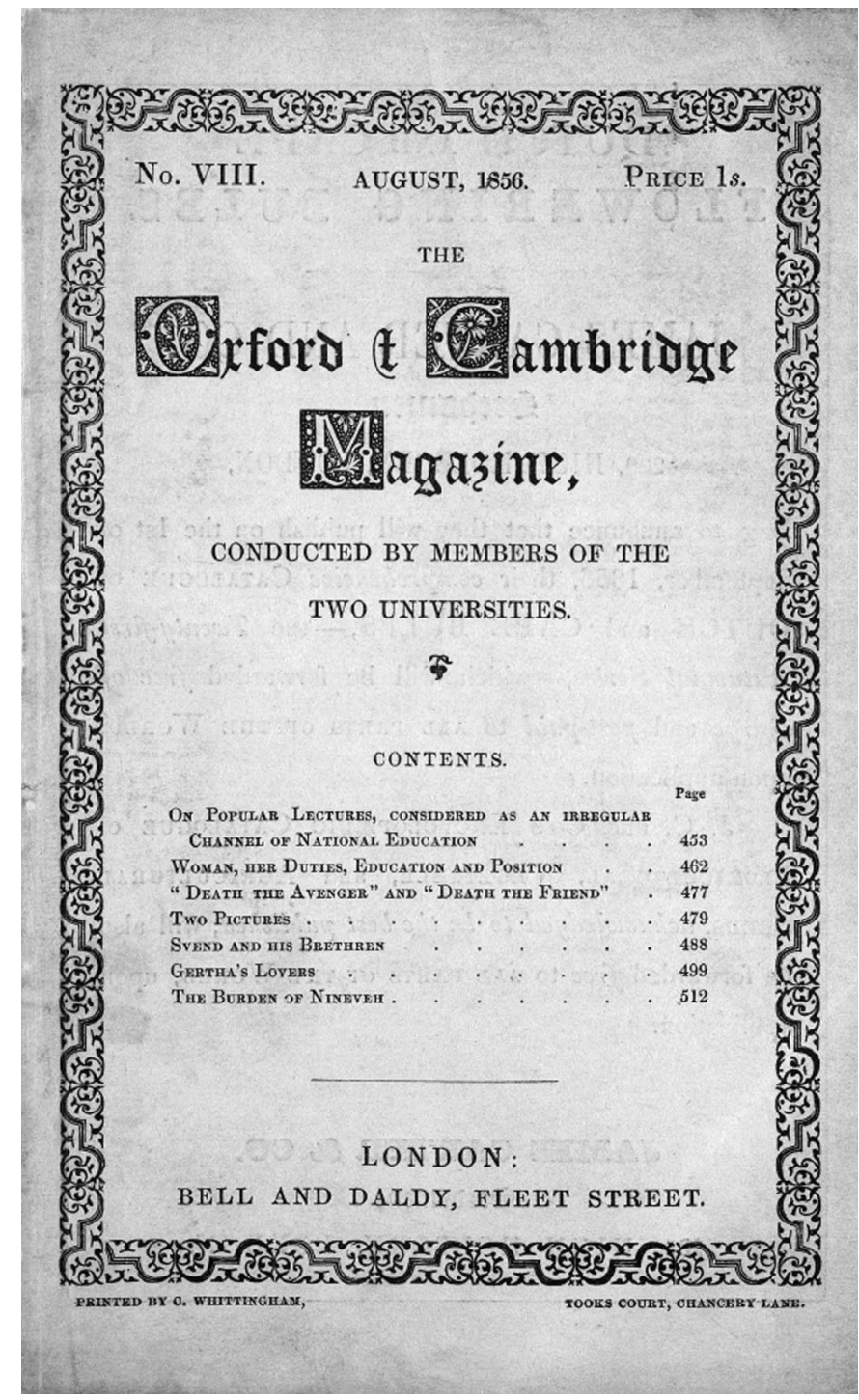

FIGURE 13. The Oxford and Cambridge Magazine, August 1856, cover. William Morris Archive. 
and sometimes even authoritative efforts for work written by men in their early twenties.

Morris signed only two of the Magazine's twenty-nine articles-"Death the Avenger, Death the Friend" and "The Churches of North France: Shadows of Amiens"-and both were devoted to aesthetic topics, as well as expressive and imaginative rather than analytical in treatment. In "The Society of the Future," he later remarked that there were "two groups of mind with whom Social Revolutionists like other people have to deal, the analytical and the constructive," and identified himself with the latter. ${ }^{48}$ By "constructive" he meant "creative," and his early critical writings blended simplicity of form and frame with emotional force, descriptive intensity, and a penchant for unexpected temporal leaps and shifts of perspective and narrative voice.

"Death the Avenger," a reflection of Morris's lifelong interest in woodengraving, introduced the reader to two woodcuts by Alfred Rethel (1816-59), a nineteenth-century admirer of Albert Dürer who was known for his historical paintings and woodcuts on the theme of death. Morris's appreciation of his work might be called "viewer-response criticism," for as Walter Gordon has observed, the essay offered "neither an historical treatment of . . . the setting of the woodcuts, nor any estimate of Rethel's merit as an engraver." ${ }^{49}$

In several passages of "Death the Avenger, Death the Friend," Morris's speaker answers personal questions of the sort Walter Pater posed in 1873 as the province of the critic in his Preface to The Renaissance: ${ }^{50}$

What is this song or picture ... to me? What effect does it really produce on me? Does it give me pleasure? . . How is my nature modified by its presence, and under its influence?

In one passage-part of his response to Rethel's images of the dead and dying-Morris recoiled before

[the m] ost terrible figure of all. In the background sits The Cholera, waiting; in her right hand a triple scourge armed at the end with goads; such firm grip of that scourge; and her left hand clasps her right arm just below the wrist, fearful strong arms and hands ... her face is black, her mouth stern, indignant, with lips dawn up tight together; fixed eyes, glaring straight forward, and lidless, . . . beneath any rebuke, any defiance; is it not strange, that

48. Kelvin, ed., Art and Socialism, 175.

49. Gordon, "A Critical Selected Edition," 101.

50. The Renaissance: Studies in Art and Poetry, ed. Donald L. Hill (University of California P, Berkeley, 1980), xix-xx. 
with all this the face is not a cruel one? ... strange that there should be even pity in it. ${ }^{51}$

Morris never lost this sense of entrapment and the desire to wrest a moment of empathy from human suffering, and it was natural as well as traditional for him to evoke the Black Death in the narrative frame of The Earthly Paradise.

In response to Rethel's portrait of a dying elderly sacristan, for example, Morris 'recalled' the sacristan's ardently vigorous youth:

They say he was a hunter in the old time, this man; that he heard the north wind sing about his ears, as he dashed over the open spaces; ... that some one used to look out for him when he rode in, in the evenings. But that too is all gone by-only in memories perhaps-yet he had other hopes then perhaps than this, a mere old sacristan dying lonely in the old belfry. (478)

Morris honored the pathos of the sacristan's death, accompanied by the singing of a bird, and presented the two woodcuts as a dialectically matched pair, probably unaware that Rethel had carved the second engraving to accommodate friends who complained that his grim images haunted their dreams..$^{52}$ In all, however, the tonalities of Morris's essay introduced Rethel to the British public and aptly conveyed the emotional intensity of the latter's work.

\section{Cigures in the CATHÉDRALE NOTRE-DAME D'AMIENS IN 1855 AND 2007}

In the spring of 2007 I took advantage of a teaching exchange in France to visit the gothic cathedral in Amiens, in an effort to understand what the twenty-one-year-old Morris might have seen. Morris would have encountered a low skyline with the cathedral rising above it, but most of the surrounding structures were destroyed by bombing ninety years later, and a new park and university bordered the canals and cathedral in 2007.

It is difficult now to see the cathedral from afar, and Morris's descriptions of the cathedral silhouetted against verdant countryside are no longer accurate, though it is surrounded by a park and bordered by a dike. The church's spire and west and south galleries-which Morris and his friends scaled, and

51. The Oxford and Cambridge Magazine, 478. Page numbers in the OCM are henceforth cited parenthetically in the text.

52. Encyclopedia Britannica, 11th ed. (London, 1910), vol. 23. 


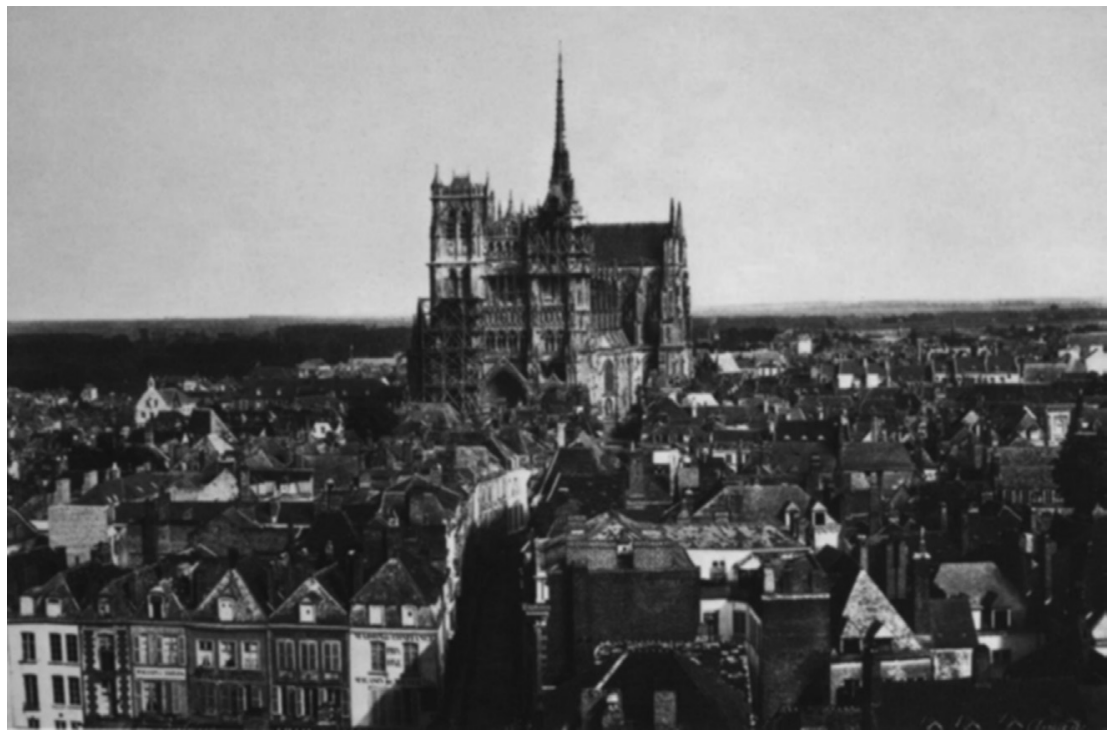

FIGURE 14. Amiens in 1855, photograph by Édouard Baldus (1813-89). Musée dè Orsay, France.

which gave them a sense of intimate contact with the cathedral recesses-also seem rather delicate now, even small, and their ascent is forbidden for reasons of safety. Morris's regret that he could not see the original colors of the nowfaded painted carvings might or might not be assuaged by the present-day annual summer illumination of hundreds of statues on the cathedral's west front-a technologically sophisticated effort to recreate their brightly painted medieval counterparts which I personally found quite pleasing to the eye.

Morris might, finally, have seen some of the dubious nineteenth-century "restorations" Eugène Viollet le Duc carried out between 1849 and 1874, and it is interesting to speculate how the founder of the Society for the Protection of Ancient Buildings would have responded to recent UNESCO-sponsored work on the cathedral's west front and southern portal, some of it underway as I watched.

It is known now that cleaning a building can remove its protective cover of oil and dirt and cause it to decay even more rapidly, so a revenant Morris might well be torn between disapproval of the process and pleasure in the cleansed façade's evocation of its original thirteenth-century state. But consider the passage in A Dream of John Ball in which his narrator / time traveler recorded that a fourteenth-century Kentish village church "quite ravished my heart with its extreme beauty, elegance, and fitness. The chancel of this was so 


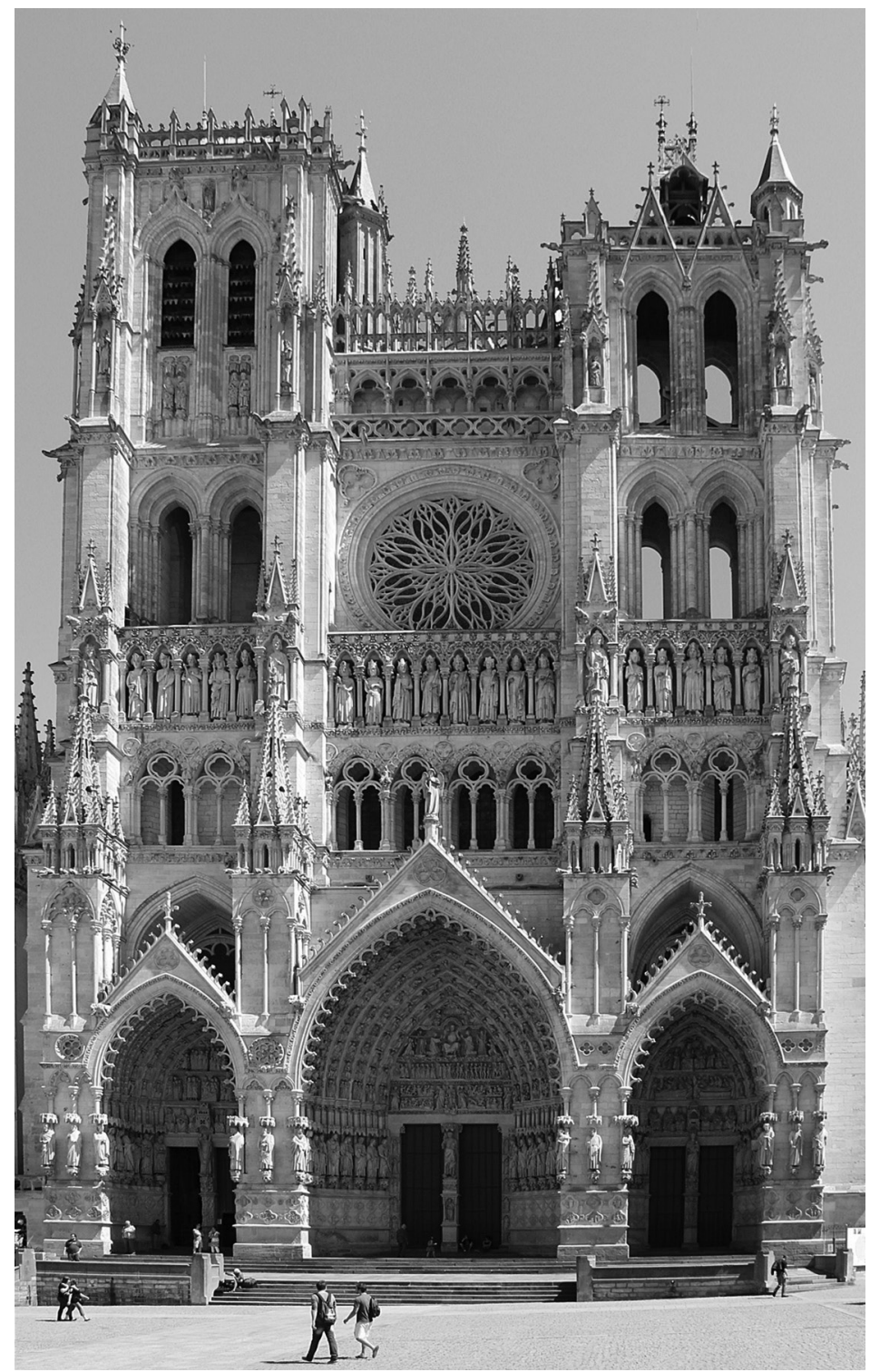

FIGURE 15. Front view of Amiens Cathedral. Courtesy of Wikimedia, Creative Commons. 
new that the dust of the stone still lay white on the midsummer grass beneath the carvings of the windows" (38).

The contrasts between the present-day Cathedral's newly cleaned facades and their adjacent area's black encrustations are indeed striking to the eye, as were the attractive but completely fictive faces of 'ancient kings' that replaced the stumps of their un-'restored' counterparts, which offered little testimony to anything other than time, eld, and acid rain.

\section{" ( HE LONGing that WAS IN ME"}

Of "Churches of North France: The Shadows of Amiens"-which appeared in the same number as Edward Burne-Jones's "Story of the North" and "The Two Partings," ${ }^{33}$ a tale once attributed to Morris-he wrote to Cormell Price that

it has cost me more trouble than anything I have written yet; I ground at it the other night from nine o'clock till half-past four a. m., when the lamp went out, and I had to creep upstairs to bed through the great dark house like a thief. ${ }^{54}$

The "thief" had originally planned to write a series of appreciations of the churches of Northern France, after the manner of Ruskin's Seven Lamps of Architecture and The Stones of Venice. Echoes of Ruskin may be heard in "Shadows of Amiens," but nothing like the prophetic voice of judgment that concludes the Seven Lamps of Architecture:

There is something ominous in the light which has enabled us to look back with disdain upon the ages among whose lovely vestiges we have been wandering. I could smile when I hear the hopeful exultation of many, at the new reach of worldly science, and vigor of worldly effort; as if we were again at

53. In style and content, "The Two Partings" seems consistent with Morris's other tales, and H. Buxton Forman and Walter Gordon included it in their lists of Morris's contributions (Gordon, "A Critical Selected Edition," 42), but May Morris did not reprint it with Morris's other Oxford and Cambridge Magazine tales in volume 1 of the Collected Works, and LeMire flatly rejects it: "it is clear enough where the most authoritative and disinterested testimony is to be had. That testimony, as the published record indicates, is unanimous in saying that Morris wrote none of the three disputed pieces" (Hollow Land, xxvii). See Boos, "Attributions of Authorship in the Oxford and Cambridge Magazine," 562.

54. 26 January 1856, Kelvin, Letters, 1:26. 
the beginning of days. There is thunder on the horizon as well as dawn. The sun was risen when Lot entered into Zoar. ${ }^{55}$

Morris, who identified more immediately and less magisterially with what he saw, sought to take his place with the craftsmen of past ages, and enter into a more personal communion with what he described:

remembering . . . the longing that was in me to see them . . I thought I should like to tell people of some of those things I felt when I was there, there among the mighty tombs of the long-dead ages. (99)

Following Ruskin's example, Morris's speaker walks the premises in the guise of a (counterfactual) guide:

I know how wonderful it would look, if you were to mount one of the steeples of the town, or were even to mount up to the roof of one of the houses westward of the cathedral; you would see the twined mystery of the great flamboyant rose window with its thousand openings. (100)

On the ground, by contrast,

from the hot Place Royale here ... you can see nothing but the graceful spire.... From one of the streets leading out of the Place Royale you can see the cathedral, and as you come nearer ... the great apse rises over you. ... We go round under their shadows. ... We go down the nave, ... we come to the transepts ... and, then, first we begin to appreciate somewhat the scale of the church. (100)

Compare this with Morris's familiar set piece of such description, the 'aerial' description of fourteenth-century London in the opening passages of The Earthly Paradise:

Forget six counties overhung with smoke, ...

Think rather of the pack-horse on the down,

And dream of London, small, and white, and clean

The clear Thames bordered by its gardens green. . . ${ }^{56}$

55. Seven Lamps of Architecture, in Rosenberg, ed., Genius, 202.

56. "Prologue: The Wanderers," The Earthly Paradise, 11. 1, 4-6; The Earthly Paradise, by William Morris, ed. Florence Boos, 69. 
Morris's narrator dissolved from these lines to an unnamed Aegean city, where Wanderers and elders have convened to exchange their cultures' tales:

Pass now between them, push the brazen door, And standing on the polished marble floor

Leave all the noises of the square behind;

Most calm that reverent chamber shall ye find,

Silent at first, but for the noise you made

When on the brazen door your hand you laid

To shut it after. ... ${ }^{57}$

In a roughly comparable (and literally 'liminal') passage in "Amiens," Morris

felt inclined to shout when I first entered [the] cathedral; it is so free and vast and noble, I did not feel in the least awe-struck, or humbled by its size and grandeur ... intense exultation at the beauty of it; that, and a certain kind of satisfaction in looking on the geometrical tracery of the windows, on the sweeping of the huge arches, were, I think, my first feeling in Amiens Cathedral. (101)

A strange sense of oppression came over me at that time, when, as we were in one of the galleries of the west front, we looked into the church, and found the vaulting but a foot or two (or it seemed so) above our heads. (102)

His camera-eye survey of the church's door, nave, chapels, transepts, choir, railings, screens, effigies, tombs, dome, rose windows, apse windows, and choir stalls led him at length to what most interested him in "the shadows of Amiens": the narrative histories in its timeworn carvings, and the parables and allegories they represented. He was especially charmed by images from the story of Joseph of the dream of the "fat and lean kine": ${ }^{8}$

I think the lean kine was about the best bit of woodcarving I have seen yet. There they were, a writhing heap, crushing and crowding one another, drooping heads and starting eyes and strange angular bodies . . . I never fairly understood Pharaoh's dream till I saw the stalls at Amiens. (101)

In another conventional scene-the burial of Christ's mother-he focused

57. "Prologue: The Wanderers," 11. 39-45.

58. Pharaoh's dream of the fat and lean kine appears in Genesis 41. 
primarily on the lonely aspirations of her mourners, in a scene reminiscent of the early prose tales' use of eager, reverential witnesses to a central tableau.

O those faces so full of all tender yearning and longing that they too ... might be with the happy dead! There is a wonder on their faces too, when they see ... the mighty power of death. (108)

Ruskin had enjoined careful attention to the coloration of cathedral stones, and admirers of Morris and Co.s stained glass praised the 'truth' of their vivid colors. Here Morris chafed at photographs of the Cathédrale Notre Dame which told "nothing about the colour of the building, in fact their brown and yellow is as unlike as possible to the grey of Amiens" (109). He also condemned

the whitewash [applied . . . in 1771, which] lies on everything so; before that time, some book says, the church was painted from end to end with patterns of flowers and stars, and histories: think-I might have been able to say something about it then, with that solemn glow of colour all about me, as I walked there from sunrise to sunset; and yet, perhaps, it would have filed my heart too full for speaking, all that beauty; I know not. (10o)

In this essay's most striking passage, previously quoted, he then evoked as living presences the builders of Amiens Cathedral-a near-mystical perception-and his desire to witness and respond to them as they worked:

These same builders, still surely living, still real men, and capable of receiving love, I love no less than my breathing friends whom I can see looking kindly on me now. Ah! Do I not love them with just cause, who certainly loved me, thinking of me sometimes between the strokes of their chisels; and for this love of all men that they had, ... for this and for this work of theirs, the upraising of the great cathedral front with its beating heart of the thoughts of men, ... I think they will not lose their reward. (100)

This, not the Anglican heaven - this yearning communal desire to record "stories of the faith and love of man that die not"-was Morris's counterpart of Immanuel Kant's Reich der Zwecke (realm of ends).

Ruskinian sensibilities resonated in this passage, of course, but Morris had modulated them in distinctly personal ways: his evocations of "love" as a solvent for suffering, for example; and his willingness to assert that the builders literally resided in their work, and were "still surely living, still real men 
. . capable of receiving love." Even more striking, even eccentric, was his certainty that these vanished builders "loved" him, and looked kindly on him at the very moment he wrote, a belief in things unseen and consoling faith in secular-artistic 'witness' which bridged centuries and framed the essay:

I thought that if I could say nothing else about these grand churches, I could at least tell men how much I loved them; so that, though they might laugh at me for my foolish and confused words, they might yet be moved to see what there was that made me speak my love. (99-100)

Notice that the future socialist's builders and artisans were not hierarchically organized into guilds or crafts, or subordinate to church officials. This was historically naive, of course: the essay elided the conditions under which the artisans worked and possible oppressions of their labor. But if recognition of a historical class system was absent, so also was belief in the relevance of rank-in Morris's artistic realm of ends all workers are equal, brothers and friends, preserved eternally unoppressed, fulfilled in their labor and participation in the succession of generations (per omnia saecula saeculorum).

In later life, Morris's medieval reconstructions were criticized for their distortions and praised for their verisimilitude. Both views were right; he appreciated certain kinds of physical and visual historical detail precisely, and ignored others altogether. He thoroughly researched later works such as The Roots of the Mountains and The Earthly Paradise, but his interest in 'important' figures was minimal: "The next scene is the shrine of some saint, this same bishop, I suppose; dead now after all his building and ruling and hard fighting, possibly, with the powers that be" (104). (Notice that Morris did at least grant this nameless bishop the dignity of one who "[fought hard, possibly] ... with the powers that be," rather than placing him among them.)

Throughout his writings Morris was consistently preoccupied with the difficult retention of past truth, the vagaries and ironies of indirect historical transmission, and the recovery and redefinition of vanishing points at the edge of human record. Artists, he believed, should piece together their own perceptions, and refrain from conscious fabrication. Other essayists sometimes suppress their source's unreliabililty; Morris made it a central rhetorical device in ways that complemented the ineffability and thus the elusiveness of what he saw. Compare the following description of an angel, for example, with his tribute to Jane Burden that "I cannot paint you, but I love you": 59

59. Philip Henderson, William Morris: His Life, Work, and Friends, 49. 
It is rather like a very fair woman's face, but fairer than any woman's face I ever saw or thought of. ... I am utterly at a loss how to describe it, or to give any idea of the exquisite lines of the cheek and the rippled hair sweeping back from it. (106)

His apologies self-consciously echo the Anglican liturgy-"Once more forgive me, I pray, for the poor way in which I have done ... that which I have attempted to do, and forgive me also for that which I have left undone" (109) - a quasi-medieval rhetorical pattern that appears again in the Launcelot lyric that concludes "Sir Peter Harpdon's End" and the "Apology" and "L'Envoi" to The Earthly Paradise.

Many of Morris's later essays and creative works ended with a prolonged leave-taking, and so did "The Shadows of Amiens." The essay concludes with a valediction in which the church recedes into the middle distance and Morris revisits what he must leave:

And now, farewell to the church that I love, .... Farewell to the sweep of the arches, ... Farewell to the spire, gilt all over with gold once, and shining out there, very gloriously; dull and grey now, alas; but still it catches, through its interlacement of arches, the intensest blue of the blue summer sky; and, sometimes at night you may see the stars shining through it.

It is fair still, though the gold is gone from the spire that seems to rock, when across it, in the wild February nights, the clouds go westward. (110)

Several Oxford and Cambridge Magazine tales associated "westward" with exploration and personal discovery, perhaps an allusion to Scandinavian histories or an echo of Charles Kingsley's recent romance, Westward Ho! (1855). ${ }^{60}$ Many of Morris's later works also ended with some counterpart of this essay's final shift of focus as the spire-supposedly a symbol of permanence-wavered in the scudding clouds.

Certain convictions or assumptions thus underlay his early work, among them

- a near-mystical exultation in the presence of beauty;

- an anagogic view of religious imagery as an evocation of human solidarity;

- a sense of intense obligation to bear witness to natural and created forms of beauty; and finally

6o. Westward Ho! or, The Voyages and Adventures of Sir Amyas Leigh, .... 
- a faith in cathedrals as living presences capable of life and death, and their builders as presences who still "lived" and "spoke."

All these modes of emotional and conceptual voice-leading can be heard in various modulations in Morris's later work, most markedly in the final farewell within the church at the conclusion of A Dream of John Ball. As in its companion-piece "The Story of the Unknown Church," there was something haunting in its elegiac intermundia, and in the young Morris's desire to honor the aspirations of those who honored others in a community of artistic saints.

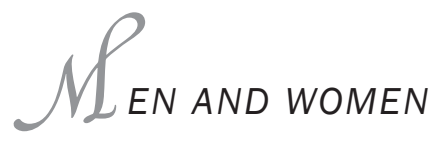

Morris's review of Robert Browning's Men and Women in the Magazine, his earliest venture into literary criticism, was a tribute to a man he considered a pioneer of the historical dramatic monologue and principled opponent of the early-Victorian establishment. In keeping with his lifelong preference for "construction" rather than "analysis," he also defended Browning's historical ventriloquism and dismissed criticisms of his style:

Now, I don't say that Robert Browning is not sometimes really obscure. He would be a perfect poet . . . if he were not. . . . though this obscurity, so called, would indeed be very objectionable if . . poetry is merely a department of "light literature"; yet, if it is rather one of the very grandest of all God's gifts to men, we must not think it hard if we have sometimes to exercise thought over a great poem, any, even sometimes the utmost straining of all our thoughts, an agony about equal to that of the poet who created the poem. (172)

... [The] accusation against Browning of carelessness, and consequent roughness in rhythm, and obscurity in language and thought, has come to be pretty generally believed ... But ... it was so with Tennyson when he first published his poems; it was so last year with "Maud"; it is so with Ruskin ... [As for $t$ ] he story of the Pre-Raphaelites, we all know that . . to this day their noblest pictures are the least popular. ... I wonder what the critics would have said to "Hamlet, Prince of Denmark," if it had been first published by Chapman and Hall in the year $1855 .{ }^{62}$

61. "The Society of the Future," in Kelvin, ed., Art and Socialism, 175.

62. CW, 1:348; OCM, March, 162-72; quotation is at 170. William Morris Archive, http:// 
As we will see, Morris would come to qualify this defense of "obscurity." Here he approaches his subject through direct reading-response and faith in the emotional truth of historicist projection:

What a joy it is to have these men brought up before us, made alive again, though they have passed away from the earth so long ago; made alive; seeming indeed not as they might very likely have seemed to us, the lesser men, had we lived in their times; but rescued from the judgment of the world, "which charts us all in its broad blacks or whites," and shown to us as they really were. $(164-65)$

It was obvious that Morris was willing to bracket historical accuracy in these passages, but so also was his yearning for Einfühlung and some sense, however counterfactual, of "the way they were" (or might have been).

In his review, Morris was clearly drawn to Browning's poems of "love" and "action," but he also considered "Cleon," "The Epistle of Karshish," and other poems "of belief [, ...] doubt, [and] the thoughts and fancies and strange longings that circle round these." Even in discussing these, however, he avoids directly religious themes in favor of political ones:

[Cleon] despises utterly the common herd; he would bring about, if he could, a most dreary aristocracy of intellect, where the commoners would be bound hand and foot, mere slaves to the great men and their great lordly minds. (163)

Brushing aside Browning's assumption that flawed people (such as Andrea del Sarto, Fra Lippo Lippi, et alia) make flawed art, he also expressed personal solidarity with "those who cannot paint":

It is very grand, this intense love of art; and I suppose that those who cannot paint, and who therefore cannot feel quite the same herein, have nevertheless sometimes had a sick longing for the power to do so ... such a longing as I think is felt for nothing else under the sun, at least for no other power. (167)

Among the "action"-poems, he praised "The Patriot" and "Before and After" (whose plots anticipated those of "The Eve of Crècy" and "The Little Tower" in The Defence of Guenevere), and singled out "Childe Roland" for his highest praise:

morrisedition.lib.uiowa.edu/oxMar.pdf. 
Do you not feel as you read, a strange sympathy for the lonely knight, so very, very lonely, not allowed even the fellowship of kindly memories. . . . I think I love this poem the best of all in these volumes. (168)

(For an analogue of this description, consider Launcelot's lonely journey to Glastonbury in "King Arthur's Tomb.") Morris readily acknowledged that Browning's "Childe Roland" was an allegory ("for in a certain sense everything is so, or almost everything that is done on this earth") but argued that "the poet's real [allegorical] design was to show us a brave man ... making his way on to his point through all dreadful things" (167), found Roland's deprivation of "fellowship" and "kindly memories" especially haunting, and expressed relief that "his life flow[ed] out triumphantly with that blast he blew" (169).

Finally, Morris had little time for poems of obliquity, casuistry, and deceit pure and simple ("A Light Affair," "In a Balcony," "A Lover's Quarrel," and "Bishop Bloughram's Apology"). But he was unequivocal in his endorsement of the "intense, unmixed love; love for the sake of love" he found in "The Statue and the Bust" and Browning's other love poems: "the sin I impute to each frustrate ghost / Is - the unlit lamp and the ungirt loin" (11. 246-47), and praised Browning's evocation of the "sweet, half-mournful music . . . in compassion to those who have not obtained this love, who will not obtain it while they live on earth, though they may in heaven" ("By the Fireside," 170).

As a mirror of his nascent literary tastes, Morris's review of "Men and Women" anticipated many of his aims in The Defence, and it tested the boundaries between empathy and identification in ways that complemented the empathetic historicism in "The Shadows of Amiens."

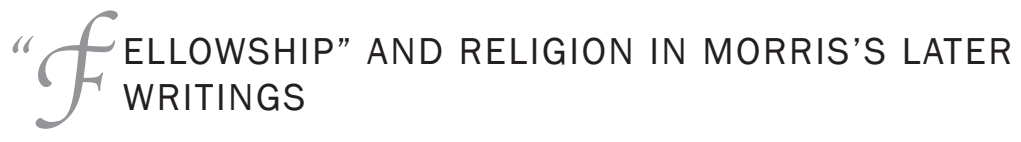

Other affinities between Morris's early writings on art and literature and his later poetry, essays, and romances are too complex to canvass here, but his association of art with love, prohibition, violence, and the rupturing of geographical and temporal sequences were clearly present in The Defence of Guenevere. "Concerning Geffray Teste Noire," for example, is a sophisticated frame poem in which a speaker witnesses the slaying of two lovers and, motivated by horror and empathy, attempts to convey their story to a 
historian who may transmit it to another generation. By the time Morris drafted The Earthly Paradise, his preoccupations with heroes, artists, and imaginative historical recreation had evolved and matured in several ways. Its narrative counterparts of the master-mason are less bemused, and the modesty of the "idle singer" is suffused with pride ("no little part it was for me to play").

The Earthly Paradise's echeloned narratives also enabled him to preserve his own voice, to present dramatic and violent conflicts in the third person, and to fashion more plausible historical forms for projection across centuries and forms of consciousness. In Orpheus, the singer of The Life and Death of Jason, as well as the disillusioned "idle singer"-narrator of The Earthly Paradise, he also found a new and more nuanced figure of the bardic poet, teller of tales and, like the master-mason, heroic preserver of a fragile cultural history.

In Morris's masque Love Is Enough (1873), 'songs' of elegiac solidarity are sung once again in a medieval church in a liminal and emblematic realm where "The Music" yields to "Love." The latter holds a palm branch and conveys to the sorely tried Pharamond a bittersweet message that "love," however evanescent, is the inexpressible force behind all life:

Reward of what? - Life springing fresh again-

Life of delight? - I say it not-Of pain?

It may be-Pain eternal? - Who may tell?

Yet pain of Heaven, beloved, and not of Hell. ${ }^{63}$

As many readers will remember, the final harvest-feast in News from Nowhere occurs inside a simple, unrestored church ${ }^{64}$ - modeled on Kelmscott Church, in whose small cemetery Morris now lies buried-and its simple "fellowship" is an emblematic scene of social harmony from which the Nowhereans' nineteenth-century "Guest" is destined to fade away.

An even more striking mature analogue of the oneiric evocations of Morris's "Shadows of Amiens" and "The Story of the Unknown Church" is A Dream of John Ball, whose installments appeared in Commonweal from November 1886 through January 1887. As previously mentioned, the figure of Morris's "hedge-priest" is modeled on the historical leader of the Peasants'

63. CW, 9:116; http://morrisedition.lib.uiowa.edu/loveisenoughtext.html.

64. "There was no modern architectural decoration in it; it looked, indeed, as if none had been attempted since the Puritans whitewashed the mediaeval saints and histories on the wall" (News from Nowhere, ed. Clive Wilmer [Harmondsworth: Penguin, 1998], 226). 
Revolt of 1382, as presented in Jean Froissart's fourteenth-century Chronicles, but his demeanor may also owe something to the revolutionary priest of Sydney Dobell's The Roman (1850). ${ }^{65}$

Like the master-mason of "The Story of the Unknown Church," the narrator of John Ball is a revenant and a time traveler with an unusually deep (though not religious) response to the beauty of churches, and the tale opens with a self-reflexive remark that

sometimes I am rewarded for fretting myself so much about present matters by a quite unasked-for pleasant dream ... I see some beautiful and noble building new made, as it were for the occasion, as clearly as if I were awake; not vaguely nor absurdly, ... but with all the detail clear and reasonable ... an old and unusually curious church, much church-wardened, ... whose trodden yellow straw comes up to the very jambs of the richly carved Norman doorway of the church. (35)

"The Story of the Unknown Church" offered the halting recollections of someone whose lifework has vanished sometime between the late medieval period and the nineteenth century. "A Dream of John Ball" bore witness to the final thoughts of a man about to die for his beliefs, in full knowledge that his cause will fail, and that the social justice for which he has sacrificed his life will be deferred and traduced for centuries to come.

The final conversation between Ball and the unnamed narrator-which also takes place in a simple medieval church—therefore evoked in this context a Paterian "sense of beauty quickened by death." The "desires" of "A Dream" have evolved into a yearning for human solidarity, and the feudal wars of "The Unknown Church" and The Defence of Guenevere have yielded to the militarism of "commercial war." Against this moloch, Morris's narrator offered his secular counterpart of the spiritual ideals expressed in John Ball's beautiful 'sermon at the crossroads':

"Forsooth, brothers, fellowship is heaven, and lack of fellowship is hell: fellowship is life, and lack of fellowship is death: and the deeds that ye do upon the earth, it is for fellowship's sake that ye do them, and the life that is in it, that shall live on and on for ever, and each one of you part of it, while many a man's life upon the earth from the earth shall wane." (51)

65. For critical responses to A Dream of John Ball, see http://morrisedition.lib.uiowa.edu/ dreamsupple.html. 
"The Shadows of Amiens" had also expressed Morris's youthful faith that the builders of Amiens could 'see' and 'love' him across the span of six centuries, and that he could reciprocate this affection and bear witness to their virtual presence. This happens quite literally in John Ball, as reflective sons of their respective centuries share the hopes and insights of their lives-a bond that may be deeper and more fully articulated than those they share with many of their contemporaries.

Motivated by a common hope that humans may one day be freed from their delusions and oppressive burdens, each understands only a part of 'history, and both search for some consolation in the face of the defeat of the Peasants' Revolt and Ball's imminent death. "Will” assures Ball that his efforts are part of an altruistic struggle which may - at some indefinite limit-be successful:

"By such grey light [of dawn] shall wise men and valiant souls see the remedy, and deal with it, a real thing that may be touched and handled, and no glory of the heavens to be worshipped from afar off... The time shall come, John Ball, when that dream of thine that this shall one day be, shall be a thing that men shall talk of soberly, and as a thing soon to come about ... and, if thou heedest this also, as I suppose thou heedest it little, thy name shall abide by thy hope in those days to come, and thou shalt not be forgotten." (110-11)

Morris's own century, of course, was a time when men would talk of a social revolution as "a thing soon to come about." But the "great change" has remained something to be anticipated-then and now-in a counterfactual time to come, when his auditors and readers and their auditors and readers might join together to realize John Ball's dream.

Such "dream"-evocations might seem to have a very clear and suggestive chiliastic resonance. But at no point did the mature Morris ever believe they might be realized in a compensatory afterlife. In his response, for example, to Ball's consoling hope that

"hereafter I shall see all the deeds that I have done in the body, and what they really were, and what shall come of them; and ever shall I be a member of the church, and that is the Fellowship; then, even as now,"

Morris's speaker gently proposed a much more attenuated form of personal survival: that 
"though I die and end, yet mankind yet liveth, therefore I end not, since I am a man ... Is the wall betwixt us gone, friend?"

[Ball] smiled as he looked at me, kindly, but sadly and shamefast, and shook his head. (89-90)

As an alternative to belief in a religious afterlife, Morris offered his comrades and anyone else willing to listen a secular "fellowship," or "religion of humanity" (so described in the 1893 co-authored Socialism: Its Growth and Outcome). As we have seen, by contrast in "Communism i. e. Property" (1892, unpublished in his lifetime ${ }^{66}$ ), a man who ardently admired medieval churchcarvers and had graced several hundred British churches with stained-glass designs asserted in passing that "religion is gone down the wind, and will no more cumber us unless we are open fools." ${ }^{\prime 6}$

Morris did remain an active lifelong advocate for the Society for the Protection of Ancient Buildings, though he ceded the office of Secretary to Hugh Thackeray Turner in January 1884 after his blunt anticapitalism prompted a great wave of resignations. ${ }^{68} \mathrm{He}$ equably agreed to submit future letters to newspapers drafted in the Society's name to Thackeray Turner or Philip Webb for their approval, ${ }^{69}$ and displaced his desire for socialist "witness" into settings where his outspokenness and radical assessments would not harm the Society's principal aims.

Good grace and conciliatory gestures aside, Morris never abridged or attenuated his agnostic convictions. He had firmly declined, for example, to take up the offer of a left-leaning leader of the Christian Socialists to join forces with the Socialist League. ${ }^{70}$ This was not a facile decision for a determined organizer to make, since quasi-Ruskinian ideals of Christian Socialism had broad appeal in fin de siècle England.

66. Florence Boos, ed., "From the Archive: 'Communism-i.e., Property: A Partly Unpublished Morris Essay," 18. For a fuller discussion see chapter 1.

67. The essay continues, "Religious tradition also hampers us but little; or need not, save the double-faced hypocrisy has now another double face, . . . for atheism stands by its old foe orthodoxy to strike a blow together with it, against true freedom \& in favour of monopoly ("From the Archive," ed. Boos, 18). See Eugene LeMire, Unpublished Lectures, "Appendix II," which lists the date of its delivery (to an unknown audience) as 21 August 1892.

68. At one of the Society's annual meetings, for example, Morris followed an inoffensive paper on "Architecture and History" with several remarks to the effect that "our commercial system" should come to an end so that ancient buildings could be preserved for the good of all.

69. Christopher Miele, "'A Small Knot of Cultivated People," 73-79.

70. Peter Jones, The Christian Socialist Revival, 1877-1914: Religion, Class and Social Conscience in Late Victorian England (Princeton: Princeton University Press, 1968). In early 1884 the Christian Socialist (newspaper) gave considerable attention to the activities of Hyndman and Morris. See also the discussion of Stewart Headlam and William Morris in Diana Maltz, British Aestheticism and the Urban Working Classes, 1870-1900 (London: Palgrave, 2006), 137-40. 


\section{ONCLUSION}

As I have suggested passim and in the introduction, many aspects of Morris's aesthetic allegiances were clearly present in his earliest essays and tales.

He remained, for example, intensely preoccupied with violence, destruction, and irremediable loss, which he gradually developed into a broader and more systemic sense of social as well as individual justice, a less 'heroic' and more collective view of the origins and resolutions of such violence, and a more nuanced sense of conflicts between good and evil than the sort he had encountered in the High Church teachings of his youth. But certain essentially ethical convictions remained invariant throughout his life-beliefs in 'the past' as repository of collective memory; in 'nature' as a wellspring of art as well as life; in ideals of 'fellowship' as a form of fraternal and sororal simplicity; and in 'useful work' and the 'lesser arts' as intrinsically pleasurable forms of artistic creation.

As he matured, he also struggled to reconcile antinomial views of violence, including 'revolutionary' violence. He sincerely admired the doomed heroes of the Paris Commune, for example, but he vigorously opposed imperialist wars, and advocated education and persuasion as the only lasting way to "make socialists." Over time, this internal dialectic also began to temper his long-standing preoccupation with romantic individualism and individual acts of courage and sacrifice, and introduced into his writings more complex reflections about the fates and situations of ordinary people confronted with pervasive forms of social and economic injustice.

His ethical and aesthetic ideals, moreover-joy in labor, simplicity of life (if not art), and deep respect, tinged with awe, for "the earth and everything in it"-were already latent in his very earliest poems, essays, and prose narratives. All they awaited was more skillful narration; a more mature sense of cause and effect, as well as lingering regret and (partial) remediation; and a more measured capacity to separate emotion from argument, narrative from testimony, and analysis from intuitive insight.

When his physical powers finally waned, Morris died as he had lived-an ardent master-mason in the great cathedral of nature and secular humanism, whose egalitarian ideals encompassed natural and built environments, as well as Immanuel Kant's "starry heavens above us and moral law within us," honored and (re)imagined in the confines of a little village church. 


\section{NTERLOCKING DREAM STRUCTURES \\ IN MORRIS'S \\ EARLY PROSE ROMANCES}

$\mathrm{n}$ his eight prose tales for the short-lived Oxford and Cambridge Magazine, Morris experimented on a larger scale with Defence-like narrators and protagonists who survive cycles of life and death and leave from time to time their 'proper' narrative frames. Variously interpreted as searchers for active vocation, romantic love, and social community, ${ }^{1}$ these figures also express hopes that they might achieve worthy ends and inspire love, and fears that they might fail in both cases. ${ }^{2}$ These prose tales also establish in an early form a pattern in which Morris offered his writings in support of a cooperative project to which, as we have seen, he contributed more than most others in the Oxford Brotherhood. ${ }^{3}$

1. For two such interpretations, see Frederick Kirchhoff, "Heroic Disintegration: Morris' Medievalism and the Disappearance of the Self," and Kenneth Deal, "Acts of Completion: The Search for Vocation in Morris's Early Prose Romances," The Golden Chain, ed. Carole Silver, New York: William Morris Society, 1981.

2. Among Morris's early medieval tales, only "Lindenborg Pool" lacks an inset romantic plot. Its nineteenth-century narrator, who dreams that he had become a thirteenth-century priest, is troubled by this transition: "I have lost my identity. . . . Yet I will be calm. . . I am resigned, since it is no worse than that. I am a priest, then," and remarks that his thoughts are "all . . strangely double" ( $C W, 1: 247-48)$. The previous fall Morris had abandoned his intention to become an Anglican clergyman.

3. Walter K. Gordon, in "A Critical and Selected Edition of William Morris's 'Oxford and Cambridge Magazine' (1856)," comments extensively on the Magazine’s history in his general 
The form of the tales hovers between fiction, descriptive essay, and historically displaced autobiography, their temporally dislocated narrative frames are strangely haunting and remote, and their language also foreshadows the cadences and imagery of his best poems in The Defence of Guenevere. I will examine in this chapter "The Story of the Unknown Church," narrated by a fictional craftsman of the sort celebrated in "Shadows of Amiens"; "A Dream," the first of Morris's tales to employ a complex community of interrelated protagonists and narrators; "Gertha's Lovers" and "Svend and His Brethren," two sympathetic accounts of erotic renunciation and the first of Morris's Scandinavian tales; and "The Hollow Land," a parable of vengeance, regret, and reconciliation.

\section{HE STORY OF THE UNKNOWN CHURCH}

Its dramatically charged language and fluid narrative structure have aroused a measure of critical interest in "The Story of the Unknown Church." ${ }^{4}$ Its dream plot is highly suggestive, and its unusual anachronisms are at once disordered and evocative. More significantly, the tale's portrayal of an intensely devoted stonemason also reconsiders an ancient question: is artistic creation a manifestation of repression, or a fitting reward for a dedicated and humane life? As a conventional narrative of love and devotion, "The Story of an Unknown Church" is a relatively slight companion tale to "The Shadows of Amiens," but it offers surreally vivid accounts of an artist's consciousness, and its narrative structure adumbrates many patterns, among them a triangular love plot and interpolated dream states, that Morris developed more clearly in his later work.

Walter, the mason of the "unknown church," is one of Morris's "still surely living, still real men, and capable of receiving love," and the exterior of his "unknown church" was once graced by a carefully carved last-judgment scene such as the one Morris evoked in "The Shadows of Amiens" (349). Walter

introduction and the headnotes to each chapter. See also Eugene LeMire, ed., The Hollow Land and Other Contributions to the Oxford and Cambridge Magazine; Roger Simpson, "William Fulford: An Arthurian Reclaimed"; Roger Hosmon, The Germ (1850) and The Oxford and Cambridge Magazine (1856); and Fiona MacCarthy, The Last Pre-Raphaelite: Edward Burne-Jones and the Victorian Imagination, 52-54.

4. Earlier critical discussions include Carole G. Silver, The Romance of William Morris, 2-12; Hartley Spatt, "William Morris and the Uses of the Past"; and Ingrid Hanson, "The Measured Music of Our Meeting Swords."”

5. Page numbers in parentheses are to the Oxford and Cambridge Magazine. 
has spent many years in carefully carving effigies of his dead sister Margaret and her fiancé Amyot, his closest friend, and his lonely memories of his loved ones and his devotedly wrought memorial are intertwined attempts to offer homage to things past.

In characteristic Morrisian fashion, the mason's representations of the two lovers who lie together in death is placed beneath a marble canopy "carved all about [not only] with so many flowers and histories" but also with "the faces of all of those he had known on earth." This culminating work of art has been his last, for he was found "lying dead underneath the last lily of the tomb." Only his spectral voice lingers now to record his hopes for "the time when we should all be together again," and thus remains the only possible interpreter of his tale.

The internal anachronism of Morris's narrative is also direct and immediate. In Walter's words:

I was the master-mason of a church that was built more than six hundred years ago; it is now two hundred years since that church vanished from the face of the earth; it was destroyed utterly,-no fragment of it was left; not even the great pillars. (128)

Morris, with Ruskin, considered Gothic architecture "a harmonious cooperative work" that was not only "inclusive of all the serious arts" but also "the most completely organic form of . . . art which the world has seen," and its unrecorded practitioners and spiritual heirs "the most useful part of [society's] population." In The Seven Lamps of Architecture, Ruskin had remarked (a bit evasively, perhaps) that "I could have wished to have given more examples from our early English Gothic; but I have always found it impossible to work in the cold interiors of our cathedrals," ${ }^{\prime}$ and claimed that "a building cannot be considered as in its prime until four or five centuries have passed over it." Morris's "unknown church," then, was in its Ruskinian 'prime' when it had been destroyed two hundred years ago, and any penumbra of it had long since vanished from recent memory. Morris later used 'ages,' 'worlds,' or centuries (saecula) in "Ogier the Dane" as symbols for a single lifetime,

6. Gothic Architecture (London: Kelmscott Press, 1893), 2. Compare John Ruskin's The Seven Lamps of Architecture, in The Complete Works of John Ruskin, ed. E. T. Cook and Alexander Wedderburn (London: George Allen, 1903), 8:224.

7. Gothic Architecture, 7, 3.

8. Ruskin, Seven Lamps of Architecture, 6. Since the "unknown church" was built before 1250 , it may have stood in the thirteenth century, for Ruskin the highest period of Gothic architecture.

9. Seven Lamps, 183 . 
but after two such (extended) ages, what living memory of the church could there be?

A narrative voice that refers to its own forty-year existence six hundred years ago is therefore "otherwordly" in more than one sense-Hartley Spatt described the effect as one of "Gothic terror" permitted Morris to express his view that a full life would have to be lived 'simultaneously' in the past and future, blend the narrative authenticity of direct confession with the omniscient recall of a third-person narrator, and argue that the only afterlife we will ever have is a confluence of love, art, and empathetic narration.

It also expresses an imperative to cherish the 'unknown', a secular counterpart of 'belief in things unseen, for what was "living not" (like the legendary figures of The Earthly Paradise) "can n'er be dead." A plausibly idealized but conjectural past can never be impugned, so we can imagine the lineaments of Walter's "unknown church" as freely as we wish. Morris later refined extensively his use of narrative frames and timeless descriptions of the distant past, for example, as we have seen in his description of the fourteenth-century peasant revolt in A Dream of John Ball.

One of the techniques Morris employed to evoke this liminal ideal was to interpolate temporal dislocations into the protagonists themselves, as when in The Earthly Paradise Ogier the Dane struggles to remember his previous secular 'lives.' Here the revenant Walter tries with some strain to recover the church's entire Gestalt:

Not one knows now even where it stood ... I do not remember very much about the land where my church was; I have quite forgotten the name of it, ... I almost seem to see it again. . . . Only dimly do I see it in spring and summer and winter. . . I remember the whole of autumn-tide; the others come in bits to me; I can think only of parts of them. (128)

Part of this cloud of unknowing may also be interpreted as a contrast between center and ground, created by an intense focus. For what was most important to Walter eventually returned, even with preternatural vividness: "I see it in autumn-tide clearly now; yes, clearer, clearer, oh! So bright and glorious.... I can think only of parts of them but all of autumn; and of all days and nights in autumn, I remember one more particularly" (128).

There is something paradoxical as well as touching in Walter's fierce joy at the transformation of his lifework into waving corn ("the most complete

10. Spatt, "William Morris and the Uses of the Past," 2. 
organic form of ... Art the world has seen?"). Someone who has labored to transmute natural forms and processes into art might be expected to regret such an Ecclesiastes-like reversion of art to grass, but Walter takes Morris's own delight in the garden's profusion:

... lush green biony, with green-white blossoms, that grows so fast, one could almost think that we see it grow, and deadly nightshade, La bella donna, oh! So beautiful; red berry, and purple, yellow-spiked flower, and deadly, cruel-looking, dark green leaf, all growing together in the glorious days of early autumn. (129)

By contrast, descriptions of the church's golden spires and carved fountains recall Tennyson's "Palace of Art," though the passage finally and characteristically returns to flowers-on the graves "of monks and . . laymen." Walter's art expresses his bitter loss, but his ultimate loyalty is to the art's natural source. Thus his deep sadness at the loss of a lifework ("destroyed utterly,-no fragment. . . . No one knows . . . where it stood," 128) is tempered by his love of what has displaced it ("the place where my church used to be is as beautiful now as when it stood in all its splendour," 128).

Eventually the narrator recalls a series of dreamlike episodes and preternaturally intense images that had assailed him before the death of Amyot as he carved a representation of Abraham at the Last Judgment on the church's western front. He had loved Amyot "better than anyone else in the world" (131), and recalled his friend in a vivid series of altered states. In the first of these, Amyot, who had departed to fight (presumably in the Crusades), speaks to the narrator seemingly from beyond the grave:

I was frightened when I saw him, for his face had changed so, it was bright and almost transparent, and his eyes gleamed and shone as I had never seen them do before. (131)

In the next sequence, both more comforting and more catastrophic, Amyot

looked down towards me very sorrowfully, I thought, ... for he looked as a man just risen from a long illness, and who will carry till he dies a dull pain. ... So I reached out my arms to him, and suddenly I was walking with him in a lovely garden. . . o oh, such birds! gold and ruby, and emerald, but they sung not at all, but were quite silent, as though they too were listening to the music. (132) 
But after this epiphany Amyot disappears, and the narrator remarks, "I felt even more sad and sick at heart than I had before when I was by the river" (132).

These dream states are then identified as premonitions, and when the carver 'awakens' he and his sister and fellow carver Margaret, who "had been betrothed to [Amyot] for some time" (132), welcome Amyot back in a moment of respite from the war, "for we had said that we should always be together" (132). When Amyot's anticipated death finally came to pass, "I felt my pain suddenly shoot through me, and I remembered what I had lost; and then came bitter, bitter dreams." His sorrow became a stab of despair when "[Margaret] said, 'Walter farewell . . . but for me, I must be with him. ... And verily Margaret and Amyot did go, and left me very lonely and sad" (133). It has been argued with some plausibility that Morris's "Story of an Unknown Church" and the early poems "Fame" and "The Three Flowers" present a triangulation that includes homoerotic or homosocial yearning. Although this seems true, what Morris's speaker seems to mourn most deeply in these early works is a loss of agape rather than eros. The rest of Margaret's farewell is psychically determined ("I must be with him, for so I promised him last night that I would never leave him any more, and God will let me go"), but Walter's soft-spoken response mourns both companions ("and left me very ... sad")."

Deprived of both those he had loved, Walter takes consolation in the power of his art to transmute their memory:

So it happened after I had carved those two whom I loved above their tomb, that I could not yet leave carving it; and so that I might be near them I became a monk, and used to sit in the choir and sing, thinking of the time when we should all be together again. (132)

The approval of an internal audience was essential to many of Morris's later narratives, and here the townspeople's growing interest becomes a testimonial to Walter's ability to transform his sorrow:

As I carved, sometimes the monks and other people too would come and gaze, ... and sometimes too as they gazed, they would weep for pity, knowing how all had been. (133)

11. If, as has been claimed, the young Morris had felt bereft at his sister's marriage to a man he admired, Walter's responses could have been similar to his own. Margaret's words of farewell in "The Story of the Unknown Church" could as easily refer to a marriage as to death: "I must be with him, for so I promised him last night that I would never leave him any more, and God will let me go." 
I was not as one on earth now, but seemed quite away out of the world. (133)

He lives to finish his lifework's final details, the best his imagination can conceive, and completes it with a carefully crafted flower of mutual love and resurrection.

So my life passed, ... till one morning, quite early, when they came into the church for matins, they found me lying dead, with my chisel in my hand, underneath the last lily of the tomb. (133)

Despite physical death, the artist's voice and consciousness remain to narrate his tale.

Inexplicable departures and returns of loved ones as signs of a preconscious world of emotion and sensation reappeared from time to time in Morris's later works-in the form of Azalais in Love Is Enough, for example, or the elusive Morgan le Fay in "Ogier the Dane." But his most equably responsive protagonists in most of these works see all, and forgive all. Walter, for example-like Thomas Mann's Tonio Kröger or the narrator of the Pilgrims of Hope-is one of Morris's lonely observer-memorialists. But his art enhances his memories, and their solace is his pleasure and his life.

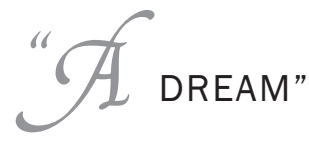

It would be hard to find a short Victorian tale more complex in its narrative structure than "A Dream," which appeared in the March Oxford and Cambridge Magazine, shortly before Morris's twenty-second birthday. Not only did "A Dream" have four internal narrators and witnesses of four inset episodes, but these narrators' interrelations with the inset protagonists were essential to the tale as a whole.

The story's emotions are not "recollected in tranquility" but refracted repeatedly and at several intricate and imbricated removes, until the final frame enacts a tableau of reconciliation. The narrators of "A Dream" tell tales of four incarnations of the same two lovers in four seasons scattered across four centuries - a structure that varied aspects of "The Story of the Unknown Church" and anticipated in miniature The Earthly Paradise's three narrative echelons and the elaborate frames of A Dream of John Ball.

Its first-person outer narrator begins with a "dream . . . that four men sat [once] by the winter fire talking and telling tales," and enters the inmost of 
these tales in its final paragraph to view the lovers' tomb before he 'awakes' and remarks that he has labored "To gather and tell oer / Each little sound and sight” (a quotation from Tennyson's “A Dream of Fair Women”) ${ }^{12}$ (155). The varied tales take place in an eclectically European feudal past, and their narrators-Hugh, Giles, Osric, and Herman (English, French, Scandinavian, and German)-might be prototypes of The Earthly Paradise's multinational "Wanderers." Hugh narrates two episodes devoted to the extended lives of the lovers Lawrence and Ella; Giles the third; and all four witness the fourth.

Morris was clearly drawn to configurations of tales-within-tales and liveswithin-lives, and the incarnations of Lawrence and Ella in the inner tales of "A Dream" are separated by Morrisian saecula quite like those of "Ogier the Dane," a major Earthly Paradise tale whose protagonist's four hundred-year life spans finally open out to infinity. The inset tales of "A Dream" also anticipate those of The Earthly Paradise, whose "singer" likens his seasonal tales to four scenes seen through the windows of a feudal castle in a wintry northern clime, and its narrators and protagonists, like the narrators and auditors in The Earthly Paradise, intermittently hear, prompt, and respond to each other.

The four witnesses/narrators of "A Dream" are formally introduced in descending order of age-Hugh, the first and principal speaker, is a whitebearded ancient; Giles is black-bearded and middle-aged; Osric is one of "the two younger men" (153); and Herman is "the youngest."13 At one point Ella informs the others that Hugh has died the night before, so Osric and Herman are understandably disturbed when Hugh and Giles reappear somewhat later, and the more-than-four-hundred-year-old Ella reappears at the end of the tale.

Perhaps they shouldn't be disturbed, since they too are centuries old by then. The best rationale for these enigmatic dissolves is that the tale's narrators as well as its protagonists 'exist' in at least two 'worlds'-within the episodes, where death is possible, and without, in a timeless narrative realm where they share their tales. In the resulting intermundium or totum simul the four narrators form a kind of collective chorus whose members shiver at each other's tales, tremble at each other's woes, and join in the end to celebrate the now-ancient lovers' long-awaited union. Readers of The Earthly Paradise as well as News from Nowhere and A Dream of John Ball will recognize prototypes of these works in Morris's early effort to superpose youth and age,

12. The Poems of Alfred Tennyson, ed. Christopher Ricks (London: Longmans, 1969), 453, 11. $276-77$.

13. For the most part, the older narrators Hugh and Giles speak as Osric and Herman listen, much as The Earthly Paradise's aged Wanderers and Elders tell their tales to younger auditors. 
memories and dreams, observers and participants, and cultures half as old as time.

More immediate parallels can be found between "A Dream" and "The Story of the Unknown Church." Both open with historical prefaces, close with public funerals, memorialize lost lovers, and embed narrators in their own tales. Walter's dream and memories are accompanied by music and sensuous descriptions of red and gold flowers; the most sensuous descriptions in "A Dream" are of Ella's musical voice, the lovers' golden hair and clothing, and a brilliant crimson sunset. Walter's friend Amyot has a deathlike pallor, and the separated lovers in "A Dream" grow more pallid in each reincarnation. Amyot appears in a dream near a cliff by water; Lawrence must enter a red cavern near a red peak by a river. ${ }^{14}$

Both tales were also designed as four-part dream episodes, marked by images of transition, into which the narrators enter as increasingly involved participants. In the first scene of "A Dream," for example, Hugh suggests that his story is indirectly autobiographical, and in the second he serves as Laurence's physician; in the third episode Giles intervenes directly but unobtrusively to save Laurence's life in combat; and in the fourth Ella and Laurence reverse the direction of intervention and walk into the narrators' frame. All of the narrators moreover have a limited knowledge of events in accord with their own positions in time, and are unable to predict outcomes or recall incidents narrated by others from the past.

Several aspects of the narrative bear out the two-'worlds' hypothesis quite early on. Hugh, for example, begins the first tale with the admission that "I have fancied sometimes, that in some way, how I know not, I am mixed up with the strange story I am going to tell you" (146), and assumes similar subliminal awareness on the part of his audience ("That strange looking old house that you all know. . . . now no one will live there now," 146; italics mine).

Hugh also quotes his father Cuthbert's description of a mysterious red cavern:

Many would have explored that cave, either from covetousness (expecting to find gold therein), or from that love of wonders which most young men have, but fear kept them back. Within the memory of man, however, some had entered, and, so men said, were never seen on earth again. (146)

Something about this 'cave' suggests The Earthly Paradise's "Hill of Venus" as well as more general and less erotic emblems of an Unknown to which suc-

14. Each of the inset scenes in "The Story of the Unknown Church" describes a body of water (two rivers, a landlocked bay, and a waterfall); the dissolves of "A Dream" are attended by tempests, wintry winds, rushing seas, and gusts of wind over the snow. 
cessive generations are inexorably drawn — an ambiguity that may account for some of Hugh's tendency to assimilate himself in some elusive way to Lawrence.

The archetypical attraction of the cave is also made more vivid when Cuthbert tells Hugh that his own father once stabbed him in the shoulder to keep him from entering it. ${ }^{15}$ And Hugh responds:

[My] father told me many wondrous tales about the place, whereof for a long time I have been able to remember nothing; yet, by some means or another, a certain story has grown up in my heart, which I will tell you something of: a story which no living creature ever told me, though I do not remember the time when I knew it not. (146)

Notice the organic liminal imagery of a tale "no living creature ever told me," which "has grown up in his heart." When he finishes the first tale, Osric and Herman are "awed by some vague sense of spirits being very near," but Giles is more impatient: "Never? old Hugh, it is not so-Speak! I cannot tell you how it happened, but I know it was not so, not so-speak quick, Hugh! Tell us all, all!" (149).

Yet, Giles is rebuffed when he tries to interrupt Hugh, frustrated at the latter's slowness in retrieving the next episode from his subconscious. The two men continue to spar with each other until Giles, "with wild grey eyes that... great brows hung over" and

breast heav[ing] as though it would burst, ... sprang up, and in a voice that was a solemn chant, began: "In full daylight, long ago, on a slumberouslywrathful, thunderous afternoon of summer," .. . Then across his chant ran [Hugh's] shrill voice: "On an October day, packed close with heavy-lying mist, which was more than mere autumn mist," ... the shrill voice went on; Giles sank down again, and Hugh [remained] standing there, swaying to and fro to the measured ringing of his own shrill voice, his long beard moving with him. (149-50)

This collaborative struggle for narrative priority ends in the second episode's reincarnation of Lawrence and Ella, he as a wounded knight and she as a hospital nurse during a plague. ${ }^{16}$ As Hugh attends to Lawrence as his physician,

15. Fathers who harm sons are fairly rare in Morris's writings, but several fathers in Earthly Paradise tales confine or imprison marriageable daughters, and one daughter (Rhodope) spurns a devoted father.

16. Military nurses were a mid-nineteenth-century innovation, and Morris may also have had in mind the London cholera epidemic of 1854 . 
Lawrence addresses him as "kind master Hugh" and Ella, a 'holy woman, presumably a nun, upbraids him ("Master Physician, this is no time for dreaming: act"). After this a healing "WEST WIND" dispels the plague (167), leaving Hugh "mixed up with the strange story ... somehow my life changed from the time when I beheld the two lovers, and I grew old quickly. . . . And that was long ago, ... I know not when it happened" (151). (Narrators too "come and till the fields, and lie beneath.")

As Giles begins the next episode, "[he] heard suddenly a breath of air rustle through the boughs of the elm. . . my heart almost stopped beating, I knew not why, as I watched the path of that breeze over the bowing lilies and the rushes by the fountain" (151). Giles's brother and his lover have recently died, and he is in mourning when he sees Ella and Lawrence, "those two whom before I had but seen in dreams by night" (151), and Ella speaks to Lawrence for the first time with open affection: "Love, for this our last true meeting before the end of all, we need a witness; let this man, softened by sorrow, even as we are, go with us" (152). Her kind gesture overwhelms Giles with inarticulate grief, but he manages to suggest that "old Hugh, or Cuthbert his father, [who] have both been witnesses before," might render them this service, and she replies ominously that "Cuthbert. . . . has been dead twenty years [and] Hugh died last night" (152). "A cold sickening shudder" shook the outer tales' two younger auditors, "but [Giles] noted it not and went on" (153).

In the tale, Giles then sets forth with Ella and Lawrence "toward the hill by the riverside" where a queen is to crown the victorious hero of a recent war, ${ }^{17}$ but as he walks with them "my nature was changed, and . . I was invisible . . f for, though the sun was high, I cast no shadow, neither did any man that we passed notice us" (152) (cf. Guest's gradual disappearance at the end of News from Nowhere). After Giles's two companions unaccountably vanish, "My own right visible nature was returned," but friends at the celebration notice that he seems distraught. He remembers proudly a past good service when "in that fierce fight . . . another, coming from behind, would have slain [Lawrence] . . . but my lance bit into his breast" (153), but is disoriented when the queen and hero assume the forms of Ella and Lawrence in a passionate embrace. Shaken by this memory, Giles quickly ends his tale, and disconcerts Osric once again with an admission that all of this has taken place "more than a hundred years [ago]" (153).

A southwest wind howls outside as the last tale begins, and Ella enters after Hugh (redivivus) urges Osric to open the door. Hugh opens it only

17. The scenario in which a queen crowns a heroic soldier may have been influenced by contemporary reports of ceremonies in which Queen Victoria honored veterans of the Crimean War. 
when Lawrence arrives somewhat later, and the winds howl yet louder. Ella's appearance (or apparition) now transcends age, as "her beauty ... seemed to grow every minute; though she was plainly not young, but rather very, very old, who could say how old?” (154). When Lawrence arrives his luminous presence dazzles Herman, who "was 'ware of some one in bright armour passing him, for the gleam of it was all about him, [and] as yet he could not see clearly, being blinded by the hair that had floated about him" (154).

Ella and Lawrence then embrace in a silent tableau before they fade into "a heap of snow-white ashes" before the four awed "witnesses," who pray for their souls and bear the news to "the people," who build a great tomb, and, Walter-like, carve the lovers' story on its sides. At this point the half-forgotten outermost narrator who has been dreaming all this contributes to the tale's Keatsian (as well as pre-Raphaelite) image: "in my dream I saw the moon shining on the tomb, throwing fair colours on it from the painted glass; till a sound of music rose, deepened, and fainted" (155).

Morris's early use of narrators who are wry or diffident witnesses of others' tales remained a basic pattern of his writings. Aspects of this narrative role may be found again and again in the characteristic blend of intense identification and narrative distance of his narrators, and their fusion of sympathy and detachment remained signatures of Morris's work throughout his long career.

\section{He lovers And the RED CAVE}

"A Dream" was the first of six early prose tales in which a protagonist seeks three forms of fulfillment: a heroic life, reciprocated love on earth, and union with his love in (some counterpart of) heaven. Only Florian in "The Hollow Land" attains all three, through gradual rapprochement with his love through several lifetimes, but Svend ("Svend and His Brethren”), Leuchnar ("Gertha's Lovers"), and Lawrence come close.

One might expect that a young male poet-like Browning in Pauline, or Tennyson in his 1833 lyrics-would begin with idealized portrayals of women, but in "A Dream" Morris's Ella is in her first incarnation a proud and thoroughly demanding object of Lawrence's unwavering devotion. Morris portrayed several such figures in his later writings-Guenevere in "King Arthur's Tomb," for example, or Gudrun of "The Lovers of Gudrun," to name only two examples-who are not simply melodramatic stereotypes, though it must be admitted that Ella's early avatar also mirrors latent imperatives of Lawrence's conscience and superego. 
Among other things Lawrence is a poor but worthy relation of Ella's wealthy father, a predicament that reappears in an early extant draft of the Earthly Paradise tale "The Man Born to Be King." The narrator of "A Dream" tells us that Lawrence and Ella's love was inevitable since both "loved beauty and good things ardently," but their "half-quarrels" suggest something a bit more complicated:

as they went on loving one another, it was, alas! not unnatural that they should sometimes have half-quarrels, very few and far between indeed, and slight to lookers-on, even while they lasted, but nevertheless intensely bitter and unhappy to the principal parties thereto. (146-47)

As Lawrence sadly engages himself in a "great war" propelled by "duty," for example, Ella ignores his affectionate farewells but takes grim satisfaction from her expectation that he will "shout [her] name among the swordflashes." He responds that he might also be motivated by "a higher love, . . . of God, [for which] I trust I would risk [my] life" (147), and dares to suggest that "knights [who have fought for a just cause] did well partly, [but] the 'ladies' [who] did as they did, that they might prove their knights . . lack[ed] faith both in God and man" (147). Unmoved by this resistance, Ella insists that he fight for her and her alone, and demands that he prove his courage beforehand by entering a vaguely sinister "red cave." Taken aback by her manner, Lawrence responds that "your face is changed, your eyes-O Christ! Help her and me, help her, good Lord," but she replies, speaking "quickly and in jerks [before] that evil spirit left her," with an ominous challenge: "dare you, for my sake, [to] sleep this night in the cavern of the red pike? For I say to you that ... I doubt your courage" (147).

Sexual imagery aside, what was this "cave"? And why "red," for it is later described as a cold sepulchral "ivory house." Perhaps the cave represents a kind of sum of all fears and néant of the soul, for Lawrence's sole consolation when he confronts it is "a prayer, ... that [God] will give me another chance or more to fight in his cause, another life to live instead of this failure" (148).

In their next incarnation, as mentioned earlier, an 'age' has passed, and Lawrence and Ella alike are pale from suffering-she from remorse, and he from his "failure." They sit quietly together as she urges him to "talk no more, dearest, but let us think only, for the time is short, and our bodies call up memories" (150). At length "the sun sank, and all was as before."

In the next episode they seem to be older still, for Ella is now a gracious queen, and Lawrence has become a vigorous hero. She embraces him publicly in an anticipation of their final reunion, and a "great rest [was] on them both, though sorrow gleamed through it" (151). 
They also brood over the chilling but elusive nature of the "ivory house," and when he tells her an "old man" had visited him in the night to tell him their reunion will be postponed for another hundred years, he "could almost weep, old though I am, and grown cold with dwelling in the ivory house ... it was scarce well done of you to send me to the ivory house" (152). At last she apologizes for his suffering, "Alas! For the weary years! My words, my sin!" (152).

When the final saeculum has passed, it is Ella who has aged beyond the usual calculations of time. She is dressed in her usual white raiment, with her golden hair now covered with the long, white veil, half bridal veil and half shroud, and she enters the narrators' dwelling actively seeking Lawrence:

Friends, has one with the appearance of a youth come here lately; one with long brown hair, interwoven with threads of gold, glowing down from out of his polished steel helmet; with dark blue eyes and high white forehead, and mail coat over his breast, where the light and shadow lie in waves as he moves; have you seen such an one, very beautiful? (154)

When he arrives she embraces him in the presence of the four narrators, now witnesses to their union, and as we have seen, the reunited couple dissolve into "a heap of snow-white ashes", and are carefully encased in a marble tomb.

In its poetic, dignified, and not entirely coherent way, "A Dream" was a remarkable tale, and its wave fronts of deferred desire, gentle melancholy, and otherworldly solidarity became a recurrent leitmotiv of Morris's later work. Its shifts of narrator and chronology have often been written off as marks of naïveté and lack of artistic control, but twenty-first-century novelists routinely employ such shifts, and Victorian poetry is also characterized by widespread experimentation with complex narrative voices, multiple points of view (The Ring and the Book), and narrators alienated from an earlier vision (“Tithonus," "Dover Beach"). Anacoluthic narrative is a flaw only if it lacks a ground-base, and Morris's compositions, like his tapestries and page decorations, showed roughly analogous patterns of symmetry broken and re-established again and again, in larger patterns that diverge from successive waves of smaller configurations, each slightly different from the next.

Morris's early fictional attempts to express his emotional identification with the role of narrative artist also bore several traits that remained deeply engraved in his mature character: sensuous identification with romantic experience; willingness to endure frustration in fidelity to an altruistic, disinterested cause; and devotion to an ideal of historical redemption for collective and personal loss. 


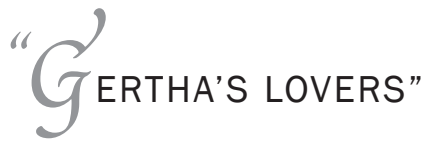

Two of Morris's early tales are historical romances with political overtones, set in a carefully evoked medieval setting. "Gertha's Lovers," the longest and most formally structured of Morris's early prose romances, and "Svend and His Brethren" (30 and 11 pages respectively in the Oxford and Cambridge Magazine for July and August), anticipated communal and egalitarian ideals Morris later shared with Lewis Morgan, Friedrich Engels, Peter Kropotkin, and others, and incorporated into his late quasi-historical romances such as The House of the Wolfings and The Roots of the Mountains. ${ }^{18}$

The tale opens with an extensive description of the beauty of a prosperous land and the politically threatened situation of its inhabitants. This has the effect of displacing the inner romantic plot as sole focus of interest, so that the tale becomes instead an allegorical expression of the aspirations of an entire people. Like the Wolfings and Roots, "Gertha's Lovers" also takes place in an indeterminately remote place and time-or in the words of the narrator of "Gertha," "never mind where or when."

Olaf and Gertha, the tale's principal lovers, achieve a happy if brief marriage until Olaf's death in defense of their people, and the tale focuses on the responses of Olaf, his friend Leuchnar, and Gertha's admirer Richard to their lives' successes and failures. Olaf rules over a country whose emblem is a white flag with a red cross of St. George, and its inhabitants carry names that seem to be Scandinavian (Gertha, her father Sigurd, Leuchnar, Beowulf) or English (Hugh, Richard, Edwin). As this mixture suggests, the inhabitants' ancestors came from the north, probably from Scandinavia:

... long, . . . long ago, from a land far over the sea, where the snow-laden pine-forests, weird halls of strange things, hang over the frozen water for leagues, and leagues and leagues along the coasts.... They came to this land with their wives and children, and here made desperate war ... with savage swamps, dragon-inhabited, daring famine, and death. (403)

The long coastline suggests Norwegian emigrants in Iceland, not Danish ones in England.

18. For comments on Morris's relationship to socialist thought regarding earlier cultures, see Florence Boos, "Gender Division and Political Allegory in the Last Romances of William Morris," Journal of Pre-Raphaelite Studies I.2 (1992): 12-23, http://morrisedition.lib.uiowa.edu/ Boos.LastRomances.pdf; and Anna Vaninskaya, "William Morris's Germania: The Roots of Socialism." 
On the other hand, the island where St. George slew a dragon was presumably "dragon-inhabited," Gertha awaits news of a battle at "St. Agnes's Abbey," and Morris might well have been pleased to characterize English fens as "savage swamps." The land may thus be some unrecorded Saxon chiefdom in East Anglia that cherishes expansionist aims, "a mighty faith withal that they should one day ring the world, going west ever till they reached their old home in the east, left now so far behind" (403-4), and that has been converted to Christianity-as witnessed by its red cross flag, convent, priests, and church, and by its characters' references to "God" and "the saints"-but which is under siege at the moment by "lazy, slavish people" ruled by tyrants.

As we have seen, while at Oxford, Morris read H. H. Milman's updated version of Gibbon's Decline and Fall of the Roman Empire, and several aspects of Gibbon's account of early Germanic tribes-election of warrior-rulers, occasional election of queens, solemn celebration of burials, and heavy use of bows and arrows-are here reproduced in a liminal realm between the possible and the counterfactual. The tale's initial descriptions of Gertha herself are iconic- "such a woman as might inspire a whole people to any deed of wise daring for her love" (403), and she spends her days singing of her country's history and acts of solidarity:

Had not Gertha then enough to think of, as she sat working hard by where the water lapped the white sand? For this people were so drawn together, that through the love they bore to one another sprung terrible deeds of heroism. ... almost every man of that nation was a hero. (404)

In the event Olaf, Richard, and Leuchnar all die bravely in battle, and one of the great heroes Gertha admires is her own father. From time to time, however, she also harbors less martial and more utopian hopes: "the west wind was joyous about her too, whispering to her softly many things concerning the land of promise" (414).

"Gertha's Lovers" also contains Morris's most extended early depiction of armed conflicts (in two out of five chapters) and attempts what amounts to an apologia for the "just war" that has triggered them, in the form of a description of their despotic enemies:

Judge whether, growing more and more cruel as they grew more and more fearful, they strained the chain over the miserable millions of their subjects so that with many it grew intolerable, and was broken asunder; so that, both in well-doing and in wrong-doing, God's kingdom spread. (501) 
The narrator also contrasts the deeds of his chosen people with the stereotypically vicious King Borrace and his allies, who are not only tyrants, but lazy, stupid, obscene, cowardly, thieving, contentious, luxury-loving, improvident, and "wolflike": "the three Dukes ... prowl always like accursed cowardly wolves as they are, gnashing their teeth ... and, stamping on the ground, invoke the devil, their cousin-german" (414). King Borrace's speech to his own men is a pastiche of insults, and his first recorded act is the murder of one of his own soldiers who has momentarily flinched from killing Gertha:

"Son of a rotten sheep. ... go and join King Olaf." So he struck him on the uplifted face, between the eyes, and Gasgan fell dead without a groan, not to be known any more by his wife or mother even, for the mace had shattered his skull. $(199)^{19}$

Such carpet-biting villainy highlights the contrasting fairness, loyalty, and mutual aid of Olaf and Gertha's army. Morris elaborates the efforts of Richard, Adolf, and Leuchnar's armies to aid and reinforce one another, their anxious efforts to know each other's fate, and their acts of genuine altruism and self-sacrifice. The tale's protagonists behave with equal selflessness in love. Olaf and Leuchnar each strives to prefer his friend's suit above their own, and Richard comforts Leuchnar when the latter despairs of his failures and his separation from Gertha. After Olaf's death, Gertha lives only long enough to lead her people to victory, then rejoins Olaf, her fallen "lovers," and her people in the pale beyond death.

Morris would have found ready antecedents for such cinematic dichotomies of friend and foe in the popular literature of his time, but in later life he opposed Manichean dichotomies and denigration of "the fallen" and their fates. ${ }^{20}$ Traces of martial sublimation lingered in The House of the Wolfings's 'just war' against predatory Roman armies (1888), and the Wolf-Folk's selfdefense against the Dusky Men (modeled on the Huns) in The Roots of the Mountains (1889).

A primary difference may lie in the fact that Olaf, Richard, and Leuchnar's idealized loyalties in "Gertha's Lovers" are primarily personal (as they probably have been in every band of brothers that has ever fought), whereas the primary loyalties of the later Germanic tribal leaders are said to be communal and grounded in genuine dedication to their people. "The people" in

19. For a discussion of problematic aspects of Morris's use of violence in these tales, see Hanson, "'The Measured Music of Our Meeting Swords.”

20. See the introduction to Florence Boos, ed., William Morris's "Our Country Right or Wrong." 
"Gertha's Lovers" are largely abstractions in the protagonists' consciousness, but Morris recreates the economic, political, and social customs of his later Germanic tribes so carefully that the reader comes to care whether they will endure. The idealized bond of mutual loyalty between four friends and lovers has become in the later romances a diffused, extended-and equally idealized-loyalty to one's threatened kinspeople and way of life.

A striking aspect of the tale is the shifting perspective of its narrative voice. Its author, for example, seems to speak directly to his (unseen) audience, comments at significant moments in his own voice, interprets his characters' emotions from within, and reports the reactions of others to what he narrates. Compare the opening sentence of "Gertha's Lovers"- "Long ago there was a land, never mind where or when, a fair country and good to live in ...." (403)-with the indifference of "The Shadows of Amiens" to details of ecclesiastical or hierarchical succession, much less 'reasons of state', that is, to much of the substance of political and nationalist history. The narrator's judgments also suggest personal and immediate sympathy with what he describes: Gertha's father is a "tiller of the kind soil," and she herself is "such ... as might inspire a whole people to . . wise daring for her love" (403). Narrative 'facts', as in “The Shadows of Amiens," are often intermingled with descriptions of their effects on the narrator, and expressed in direct address, exhortation, and rhetorical questions.

What thoughts were hers, as she sat working on that summer morning ...?

What thoughts? (403)

Did she not then sing, joyously and loud-ringing ... ? (404)

Judge, therefore, whether the tyrant kings feared these brave, free men! Judge whether, growing more and more cruel as they grew more and more fearful, they strained the chain over the miserable millions of their subjects so that with many it grew intolerable, and was broken asunder. (404)

Who is this inner narrator's assumed audience? It cannot be a group of persons contemporaneous with the tale, for the latter has occurred "long ago, never mind where." Even so, a generalized sense of friendly intimacy is furthered by interjections, such as "Many a song could Gertha sing you," or "O! you all know what it is to be second in such a race; it is to be nowhere" (412). The later prose romances employ highly complex verbal methods and devices to provide an overview of what happens in them, so much so that Frederick Kirchhoff has suggested that these later works read as if they were directed 
to "another reader." ${ }^{21}$ The narrator of "Gertha's Lovers," by contrast, seems to speak directly and sometimes colloquially to his audience, as if literally addressing several people at once, a directness sustained by suggestions of reflections from without as well as within:

Why she, weak woman as she was, had not she seen the enemies' ships hauled up on the island bank yonder, and burned there? . . she saw . . . clearly enough, the two noble knights especially, one very grand and noble ... fancy such an one, so wise, yet so beautiful, that he moved like the moving of music. (504-5)

The speaker of "The Shadows of Amiens" responds to a burial scene with a direct outburst of emotion. In "Gertha's Lovers," the narrator concludes with an emotion-laden description of the unfinished Church that commemorates the lovers, "towering so high above the city roofs toward the sky, . . . like a mountain cliff that went a wandering once, and by earnest longing of the lowlanders was stayed among the poplar trees for ever" (512).

The overriding quality of Morris's narrative voice, moreover, is empathetic identification with the 'internal' emotions of his characters, and the extent and intensity of this identification usually reflect the author's sympathies: we have King Borrace's malicious oaths, for example, but not his inner thoughts. The initial focus is wide:

... think of the many who, though they fought not at all with spear or sword, yet did, indeed, bear the brunt of many a battle in patiently waiting through heart-sickening watchings. (404)

In an anticipation of Morris's sympathy with the anguish of Bodli in "The Lovers of Gudrun," much of the tale's acuity and intensity focus on Leuchnar's resignation when he learns that Gertha prefers his closest friend:

Poor fellow! He had expected sudden clasping of Olaf's arms about him, praise for his nobleness, consolation for his failure. Ah! Did he not know himself what a passion love was? . . . It was only now in his disappointment that a certain natural instinct made him catch at all the love that came across him of whatsoever kind. That was why he thought so much of Olaf now. (412)

21. Frederick Kirchhoff, introduction to Studies in the Late Prose Romances. 
Or his thoughts before the battle in which he loses his life (compare the reflections of Tolstoy's Prince Andrey, the night before he is fatally wounded at Borodino):

These thoughts, and how many more, he thought in a single instant of time: how many pictures came up to be gazed on as it were for a long time, in that instant! ... the high roofed cottage, whereon the loving golden-glowing stone-crop grew. ... even as they say that the drowning man ... sees rather his old home, and all the things that have been, for memory is cruel-kind to men. (416)

Olaf too is a sensitive and scrupulous man whose inner conflicts are narrated with care, but-as with Kiartan in "The Lovers of Gudrun"- there are fewer of them.

Throughout "Gertha's Lovers" sympathetic shifts from inner to outer points of view can produce a triangulated effect, especially in descriptions of women. In the descriptions of Gertha, and elsewhere in Morris's early writings, the outward signs of women's distress are presented as though they were the emotions of the women themselves:

Did not her eyes flash, her brow and cheeks flush with triumph, her heart swell and heave beneath her breast, when the war-music grew nearer and louder every moment; and when she saw at last the little band of her dear countrymen .... (404)

Here it is as though she were not thinking thoughts, but thinking through her bodily reactions. In the present context this is a slight touch, but a similar superposition of viewpoints underlies the frisson of such portraits as that of Guenevere in The Defence.

Morris's narrator also uses two witnesses to add variety and credibility to his tale. The aged warrior-counsellor Barulf, an early version of a type represented by Thiodolf in the later German romances, provides a counterweight to the story's sensitive young lovers, and in the work's final section Gertha's handmaiden Edith describes her mistress's last hours to "the Knights and Lords."

In the handmaiden's account, as Gertha prepared to die alone, she was met and embraced by the spirit of Olaf. The two had conversed quietly in a twilit field until sunset, after which Edith approached and found her dead. There are clear parallels between Edith's account and the conclusion of "A Dream," but there is something quietly poignant about the lovers' liminal 
conversation in a twilit field until Gertha's death. Barulf and his knights provide a testimonial frame to Edith's tale, and "the people" build a memorial to the couple in a properly Morrisian unfinished church. The outer narrator describes this in appropriately architectonic terms as a place hovering 'twixt heaven and earth:

... to this day the mighty fragment, still unfinished, towering so high above the city roofs toward the sky, seems like a mountain cliff that went a wandering once, and by earnest longing of the lowlanders was stayed among the poplar trees for ever. (512)

Morris often used such indirect testimonies to recount mythical or epiphanic events, a technique that carefully bypasses questions of literal faith and leaves transcendence to the eye of the beholder. In this first third-person prose narrative, Morris honored in a mythical "people" a sense of mystery and memorialization of their dead, and outlined a prototype of his echeloned narrative structure in The Earthly Paradise and later prose romances. The resolutions of "A Dream" and "Gertha's Lovers" are markedly less inchoate than the burial at the end of "The Story of the Unknown Church," but all three commemorate artistic endeavor and successful love.

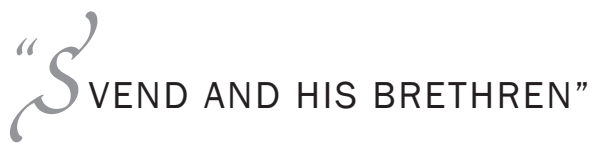

A brief eleven pages, "Svend" appeared in the Magazine just before the last segment of "Gertha's Lovers" and may have been adapted to the layout of the August issue. Its title is something of a misnomer, for its primary initial focus was not on Svend and his brothers but on their mother, Cissela, and her lover, Siur. If one thinks of successive generations as a unit, the same interlaced frame structure organizes this story as in "A Dream" and Morris's other prose tales, here reinforced by historical referents.

A certain king Valdemar from an "olden time" had subjugated his unwilling subjects and exploited their sweated labor for his imperial ambitions:

... year by year the serfs, driven like cattle, but worse fed, worse housed, died slowly, scarce knowing that they had souls; they builded them huge ships, and said that they were masters of the sea too; only I trow the sea . . . sent them back their ships cut into more pieces than the pines of them were. . . They sent great armies to all the points of heaven, wasted many fields and 
valleys, blotted out from the memory of men the names of nations, made their men's lives a hopeless shame and misery to them, their women's lives disgrace, and then-came home to have flowers thrown on them in showers, to be feasted and called heroes. (489)

The parallels with imperial Britain in these lines are clear, as is the following lines' parallel with John Ball's "proud dispiteous rich man" who was "in hell already but doth not know it":

Alas! Alas! They were slaves_king and priest, noble and burgher, just as much as the meanest tasked serf, perhaps more even than he, for they were so willingly, but he unwillingly enough. (489)

As the tale opens a resistance movement in the nearby mountains has languished, and a grey-haired man with the "look of [someone] who, having done his best, is yet beaten" waits anxiously in his simple stone house in a "walled town" (490) for the arrival of his children Eric and Cissela. The latter's offer to sacrifice herself as a trophy after she has narrowly escaped capture evokes bitter memories of past atrocities by both sides, and he wistfully recalls a prophecy that "they say, that at the last we may be saved from utter destruction by a woman" (491).

Inspired by such musings, Cissela enters a nearby chapel filled with effigies of "men, roughly cut . . . but grand, because the hand of the carver had followed his loving heart" (492), and offers herself in sacrifice ("Christ God, ... so help me, as I refuse not life, happiness, even honour, for this people whom I love," 492). Her lover, Siur, cries out "May God forgive me as I am true to her!," breaks a ring in two so that each may retain half, and bids farewell to her forever ("Even if a man had spent all his life looking for sorrowful things ... yet would he have found nothing in all the world, or perhaps in all the stars either, so sorrowful as Cissela," 492). She steps over shrouded bodies of the dead to become Valdemar's wife, an armistice is proclaimed, and "soldiers and lords [of both sides] shouted: 'Hurrah for the Peace-Queen, Cissela!”' (494).

Years later Siur, now an armourer, encounters Robert and Svend, two of Cissela's sons, and the young Svend dreams of becoming "the justest king in all the earth, ... [ [with] everywhere love, and peace if possible, justice and truth at all events" (494), and crafts a crown from one of Siur's daggers. Siur makes a present of the dagger-crown and requests that the boy ask his mother "if she is happy now," and Cissela responds with deep emotion that "I am happy, but not so happy as we shall be, as we were" (495). 
When Cissela dies the king asks Siur to carve his effigy with that of his dead wife, and Siur completes the queen's image but refuses to carve the king beside her. The chastened king sits beside his wife's tomb with his right arm across her carved breast as the tale nears its end, and dies soon thereafter. In commemoration of her, Siur crafts suits of armor for her sons, on the breast of which

was a face worked marvellously in enamel, the face of Cissela in a glory of golden hair; and the glory of that gold spread away from the breast on all sides, and ran cunningly along with the steel rings . . . : moreover on the crest of each helm was wrought the phoenix, the never-dying bird, the only creature that knows the sun. (496)

Svend ascendant is described as "perfect . . . in wisdom and strength," as in various ways are his "brethren," William, a harpist, Harald, an astronomer, Robert, a craftsman and metalworker, Richard, a poet drawing "men's hearts from their bodies, with the words that swung to and fro in his glorious rhymes," and two unnamed brothers who have discovered "an island ... long and long away to the west" (496). Nonetheless, in his first public appearance as sovereign Svend faces a belligerent mob who cry for "War! War! Give us war, O king!", and when he resists- "NO WAR with my brother's people" (497) - he and his brothers are mocked and attacked. His quickwitted response is an imperialist diversion that echoes the rhetoric of Charles Kingsley's Westward Ho! (1855):

As he spoke he let his black cloak fall, and up from their sheaths sprang seven swords ... on the blades of them in fantastic letters of gold, shone the word WESTWARD. Then all the terrace gleamed with steel, and amid the hurtling of stones and whiz of arrows they began to go WESTWARD. (498)

As his fascination with martial accoutrements makes clear, Svend was no pacifist, but a 'wanderer' avant la lettre in search of higher principles and an "earthly paradise":

[He took] aboard those ten ships whosoever had prayed to go, even at the last moment, wounded, or dying even; better so, for in their last moments came thoughts of good things to many of them, and it was good to be among the true. (498)

Before the little flotilla sets sail he dons the iron circlet he had crafted from Siur's dagger as a boy, and he departs with his fellow-colonists in peace. 
In an epilogue of sorts, the reader learns that a certain "William the Englishman" has crafted his own circlet:

Here ends what William the Englishman wrote; but afterwards he . . found the books of a certain chronicler which saith: "In the spring-time, in May, the 550th year from the death of Svend the wonderful king, the good knights, sailing due eastward, came to a harbour of a land they knew not . ... they ... a afterwards, going back to their ships, sailed away marvelling. And I John who wrote this history saw all this with mine own eyes." (498)

What "John" and the other voyagers had found was a ghastly tableau of the murderous mob that Svend and his brethren had left behind:

... about the quays and about the streets lay many people dead ... for they had, some of them, ghastly wounds which showed their entrails, and the structure of their flesh, and veins, and bones. . . Moreover the streets were red and wet with blood, and the harbour was red with it. (499).

"Svend" is thus a tale within a story within a history, set six-hundred years before the time of "William the Englishman," and roughly contemporaneous with "The Story of the Unknown Church." As in "A Dream," "The Story of the Unknown Church," and the echeloned narratives of The Earthly Paradise, the allegory of "William the Englishman" is only clear to its narrator as it unfolds, and can only be completed by his empathetic successors.

\section{"T He hollow LAND"}

"The Hollow Land," which appeared in two segments in the September and October issues of the Oxford and Cambridge Magazine, was one of Morris's longer early tales (21 dense Magazine pages). Divided carefully into three chapters, the third of which was subdivided into three "fyttes," it also included a pair of inset quasi-medieval songs, "Queen Mary's crown was gold," and "Christ rest the hollow tide." A bildungsroman cast in the mode of dream allegory, it features a protagonist who moves through a series of highly charged dreams, conflicts, altered states, and near-death experiences as he learns to temper his violence and seek inner and outer peace.

Chapter 1, "Struggling in the World," opens with a statement of the tale's theme, far broader than its individual plot and framed as a direct appeal to the reader: "Do you know where it is—the Hollow Land?" Like the reader, the 
now elderly narrator also does not know the answer: "I have been looking for it now so long, trying to find it again—the Hollow Land-for there I saw my love first." Instead his memories are of violence- "in my ears and eyes . . . a ringing and glittering of steel; drawn-back lips, set teeth, shouts, shrieks, and curses." Such conflict is culpable, "making those sad whom God has not made sad," but it also represents a refusal of what should be life's main goal: "alas! alas! What chance for any of us to find the Hollow Land? What time even to look for it?” (565).

The tale's protagonist is Florian of the house of the Lilies, a well-omened name in a story in which flowers suggest the fullness of natural beauty. Florian's first actions are an attempt to prosecute a long-standing feud between his household and that of a certain Red Harald, whose mother, Swanhilda, had been guilty of striking his brother Arnald with her scepter in a fit of pique when the boys were still young. Sixteen years later Arnald wishes revenge, and Florian eagerly agrees to aid him: "because my heart was wicked, I rejoiced exceedingly at the thought of vengeance" (566). The brothers sacrilegiously pray for victory, and Florian looks forward to "the first time I expected to use a sharp sword in anger" (566). Accordingly, the brothers and their men enter stealthily by night the fortress that contains a palace in which Swanhilda and her company lie sleeping, kill many of the guards and townspeople, and capture Swanhilda in her palace.

At this point a mock trial occurs, at which Arnaud accuses her of having struck him years earlier, "disgracing me before all the people." Since this charge might not seem worthy of a death sentence, he brings forth a more serious, hitherto unmentioned accusation, that she has murdered her husband, who it seems was Arnald and Florian's cousin. All of the Lilian men likewise proclaim Swanhilda's guilt, and despite her desperate pleas and stout resistance-she wounds many of the men who seek to confine herArnald runs her through with his sword. Not surprisingly, Swanhilda's son is roused to anger, and the feud between the households erupts into warfare. When the people of the House of Lilies gather in their church, St. Mary's, its largest bell, "Mary," traditionally pealed only on occasions of grave danger, rings out, and as Harald's forces surround the church the people of the Lilies escape to their previous homeland in the hills, led by their abbot and Arnald.

Chapter 2, "Failing in the World," records events in a liminal space between Red Harald's land and the hills, where Florian, Arnald, and five hundred others are trapped by Harald's men and unable to escape through a mountain pass. Even loyal soldiers of the Lilies fear that their woes have been deserved, however: the brothers' right-hand man Squire Hugh confesses that 
"thirty years ago I thought this, that the House of Lilies would deserve anything in the way of bad fortune that God would send them" (573); and in the midst of battle a fellow knight breaks into tears and accuses Florian of satanic origins and purposes: "Sir Florian, men say that at your christening some fiend took on him the likeness of a priest and strove to baptize you in the Devil's name. ... I think, we all think, that we have been led into some devil's trap or other" (575).

At this point Florian adopts the unexpected role of repentant moral leader. He assures his followers that even if God punishes them for their sins, "is it not certain that He cares for us yet," and exhorts them to courage: "brave men, brothers, ought to be the masters of simulacra-come, is it so hard to die once for all?" (575). His resolution avails nothing, for at this point Red Harald advances, dressed in his identifying red robe, and Florian realizes that he and Arnald have been captured. Arnald mourns that "we must die, and . . . the House of the Lilies is just dying too," and now regrets the murder of Swanhilda that had precipitated this recent battle: "I repent me of Swanhilda's death; now I know that it was a poor cowardly piece of revenge, instead of a brave act of justice; thus has God shown us the right" (576).

Florian watches with horror as all but the loyal Hugh and ten followers defect to Harald's army and Arnald is forced to accompany them, crying out, "I pray thee, Harald, forgive me!" before he and his horse are slain. As Florian and his few companions lash out in anger, they are forced backwards by Harald and his men toward the hillside and what seems imminent and certain death. At this point realism falls away, however, and Florian stumbles into a chasm, grasping on his way down "a tuft of yellow broom" as he faints, and as the chapter ends he descends into "the Hollow Land."

In "Fytte the First" of chapter 3, "Leaving the World," Florian awakens, not to death, but to a "cool green light" in a lovely land of flowers where a woman, Margaret, sits tending him and singing "Christ keep the Hollow Land / Through the sweet spring-tide." His response is love, but also fear"yet withal no one, man or woman, had ever frightened me half so much" (632) - and when she holds out her hand he repels her advances with symbolic awkwardness: "in my swinging to and fro the steel sheath of my sword struck her on the hand so that the blood flowed from it" (633). Clearly not ready for love, he hastens off to look for his brother, and in a forest near a stream finds the body of a dead knight whom he recognizes as Arnald: "he was as dead as Swanhilda" (634).

As Florian grieves he notices that the lovely maiden has followed him, and when he protests that his brother's deed had been just, for "What right had Swanhilda to live?” Margaret chides him for a false vengeance: 
"So! .. . must I then, though I am a woman, call you a liar, for saying God is unjust? You to punish her, had not God then punished her already? . . . Whether by night or day, what things but screams did she hear when the wind blew loud round about the Palace corners? .. . Unjust! Yes truly unjust enough to take away life and all hope from her; you have done a base cowardly act, you and your brother here." (634)

Despite Margaret's reproofs he pleads for her compassion and declares his love; mollified, she responds affectionately and together they bury Arnald, who recedes into his past: "And I have never seen him since, scarcely even in dreams" (635). His idyllic tryst with Margaret ends, though, as they meet with a weeping woman dressed in scarlet and gold (ominously Swanhilda's colors), with her head bowed so as to be unrecognizable. Chilled, Margaret says, "Florian, I am afraid: let us come away," and at this point his sojourn in the "Hollow Land" ends abruptly.

In "Fytte the Second" Florian is forced to confront his nemesis, Red Harald, and begin the process of reorientation and atonement. In the gap between "fyttes" he has aged: "I had lost my best years somewhere ... my hair and beard were scattered with white" (635), and symbolically, his clothes have become dirty and discolored, though he retains his sword. As he hurries away through a forest he encounters a lake and plunges in, but he is impeded from swimming by his clothes, and notices ahead of him a man in a boat, dressed in scarlet clothing with yellow and black stripes and holding a spear, who then (as he experiences it) spears him on the shoulder.

When Florian recovers he is lying naked on the lakeshore, from where he sees afar the ancient castle of his ancestors. Resolving to die there, oblivious to his nakedness, and still holding the precious sword, he toils up the hill to the now dilapidated castle and stands in his father's hall to begin the process of rebirth:

I . . stood in the great hall at last—my father's hall-as bare of everything but my sword as when I came into the world fifty years before: I had as little clothes, as little wealth, less memory and thought, I verily believe, than then. (686)

The walls are covered with scarlet and yellow paintings, colors now of course abhorrent to him, and decorated with the painted faces of those most prominent in his inner world: Red Harald, Swanhilda, Arnald, himself, and an unknown, beautiful woman. Here he meets a man clothed in red who is painting, and the two dispute, each claiming to "paint God's judgments" 
(637). The other attacks him, and the two engage in a swordfight, spinning around "to the measured music of our meeting swords" (638) until his opponent falls in apparent death. Eccentrically, if symbolically, Florian paints the prostrate man's face in red, yellow, and black, forming a grizzly, even sacrilegious, parodic work of art:

I . . painted his face thus, with stripes of yellow and red, crossing each other at right angles; and in each of the squares so made I put a spot of black, after the manner of the painted letters in the prayer-books and romances when they are ornamented. (639)

At length Florian's "heart misgave me, and I hoped that he was not dead" (638), and he washes off the colors, places his erstwhile opponent on a makeshift bed, and dresses his wounds.

Not surprisingly, after this act of restoration Florian is able to find raiment in the appropriate color, green, "and I clothed myself" (638). After the painter is restored to health the two men exchange fictive names and begin to paint together, their hostilities forgotten; "as the years went on . . . we painted purple pictures and green ones instead of the scarlet and yellow, so that the walls looked altered, and always we painted God's judgments" (639). At length the two men witness a passing funeral procession for a foreign king, and are moved by the imagery on the shields of the attendant knights, in which are images of "the two hands of one who prays for forgiveness" (640). At this point the painter takes from his breast "a long, long tress of black hair" (presumably Swanhilda's), over which he weeps. This act apparently prompts Florian's sympathy; in any case he fetches armor for himself and his friend, and at last acknowledging his companion's identity, he bids him, "O! Harald, let us go!"

The two men depart together until they encounter the weeping woman clothed in scarlet (the figure Florian and Margaret had met previously in what seems a prior life or state of consciousness), and Harald leaves with the scarlet woman, presumably a reincarnation of his mother, and "him I never saw more." Florian continues on, "quite lonely, but happy" (640), until he finds what he recognizes as the entrance to the Hollow Land, and this time he enters voluntarily, letting himself "down most carefully," until he falls asleep.

"Fytte the Third" is brief, for Florian wakes rejuvenated to hear Margaret singing, this time the full two stanzas of "Christ keep the Hollow Land." She invites him to seek "a hollow city in the Hollow Land," a journey which they make, "we two alone... no soul will ever be able to tell what we said, how we looked." 
At last we came to a fair palace, cloistered off in the old time, ... and [I] turned, and seeing Margaret, saw that her face was that face seen or half seen long and long and long ago .... we walked together toward the gold gates, and opened them, and no man gainsaid us.

And before us lay a great space of flowers. (640-41)

This is perhaps the most attractive ending of these early tales, carefully prepared for through Florian's prolonged tribulations and moral education. As the tale ends there are no witnesses to the lovers' entrance into this realm of natural beauty, and no narrators to claim that it is just a tale. As in the other prose tales, the hero's outward and inner life has progressed through a series of temporally disconnected symbolic frames. "The Hollow Land" is distinctive, however, in that a flawed hero's limitations are clearly identified, and he is granted repentance, purgation, and (although who can say that the Hollow Land "exists" in time) a happy, unsublimated union with his love.

Mid- and late-Victorian poetry and fiction were marked by the presence of alienated or disoriented narrators ("Tithonus," "Dover Beach") and complex voices and multiple points of view (Middlemarch, The Ring and the Book). But Morris's uses of audiences, narrators, and uncertainties and resolutions en abyme were distinctive, in ways that suggest the echeloned and selfsimilar configurations of his designs.

Even in his less accomplished early works, Morris strove to make their inner and outer frames complement each other, and when he succeeded, he achieved a fleeting harmony made possible in part by his focus on the process of narration, and in part by his desire to reconcile motifs of love and artistry in a heroic life. Narrators' roles as 'witnesses' of others' lives and the artistic vocation of such 'witness' remained central literary preoccupations of Morris's life, and the fusion of narrative detachment and sympathy for an entire situation made possible the broadly based, multiple point of view that distinguishes even Morris's early poetry and prose. 


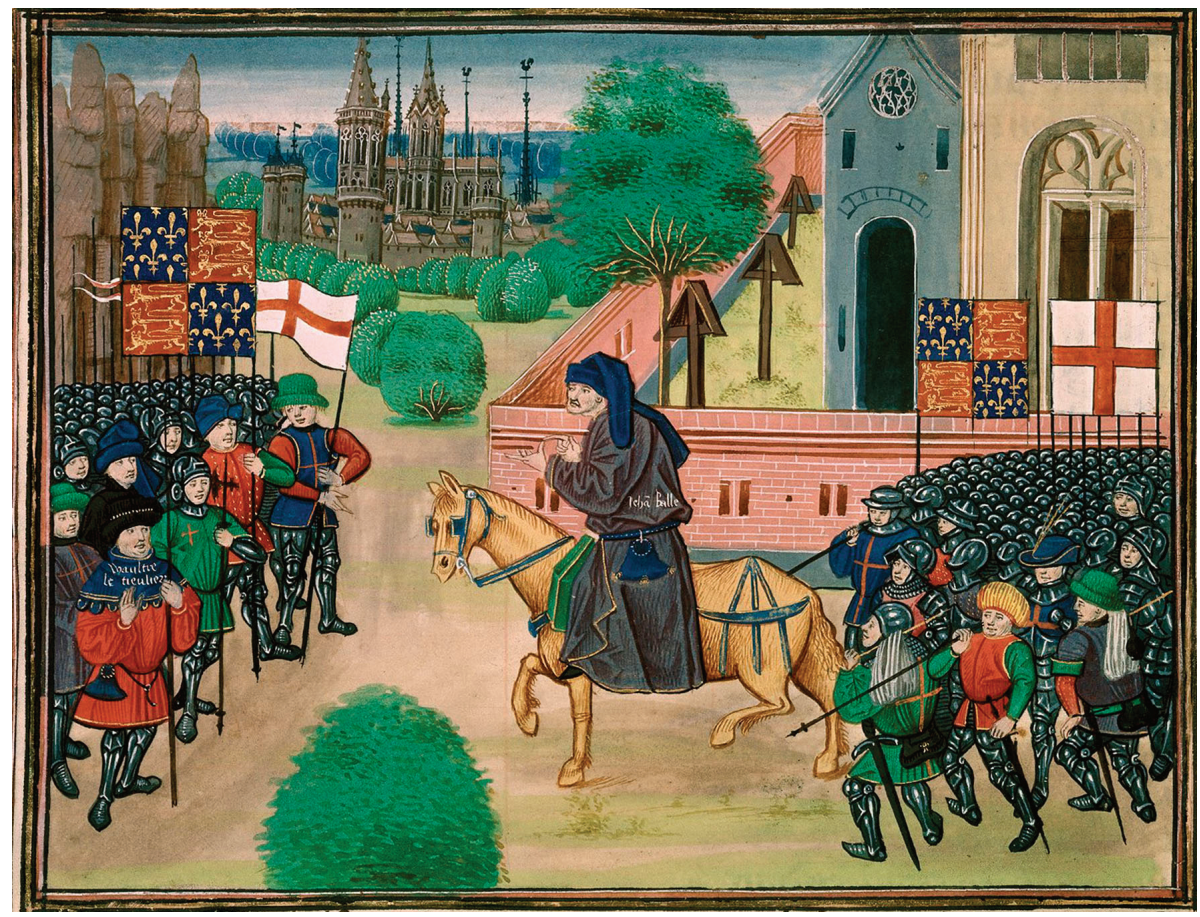

PLATE 1. Picture of John Ball. Detail of Froissart's Chronicles, unknown medieval artist. Courtesy of the British Library. 


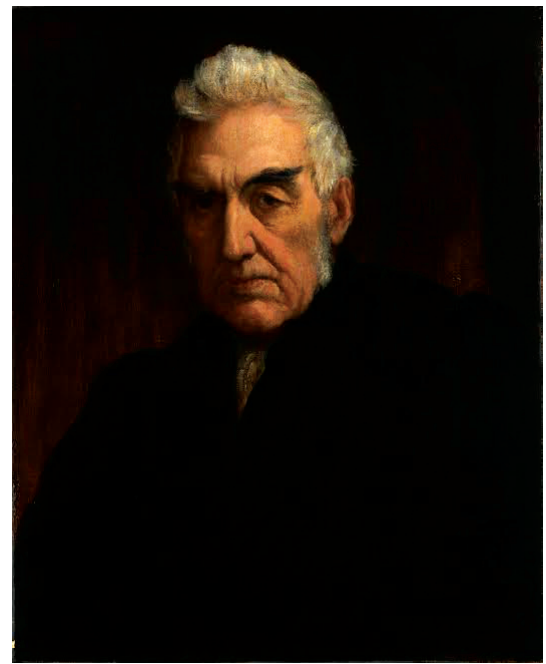

PLATE 2. Henry Hart Milman, author of The History of Latin Christianity, 1855. George Frederick Watts. Courtesy of the National Portrait Gallery. 


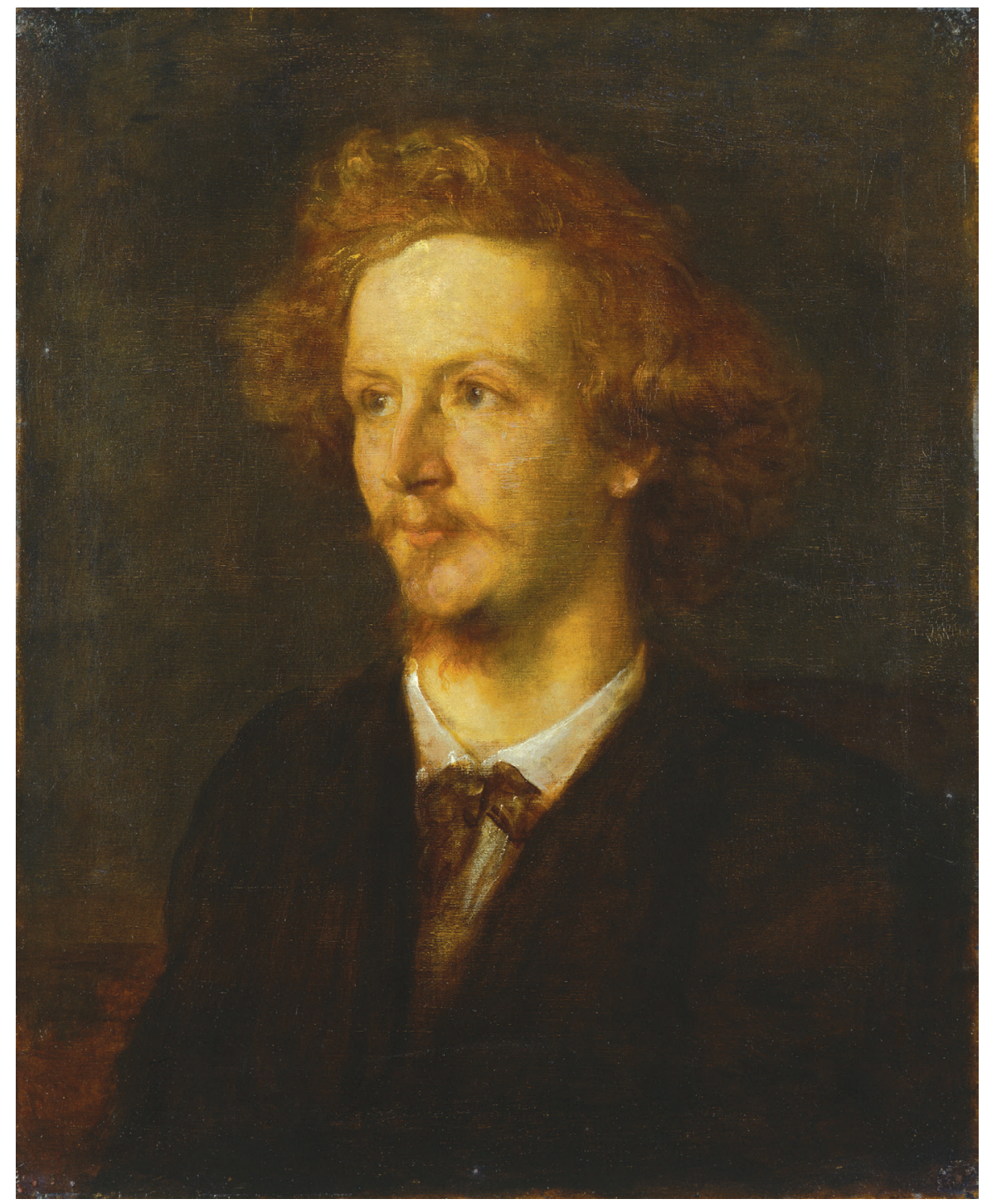

PLATE 3. A. C. Swinburne, by George Frederick Watts. Courtesy of the National Portrait Gallery. 


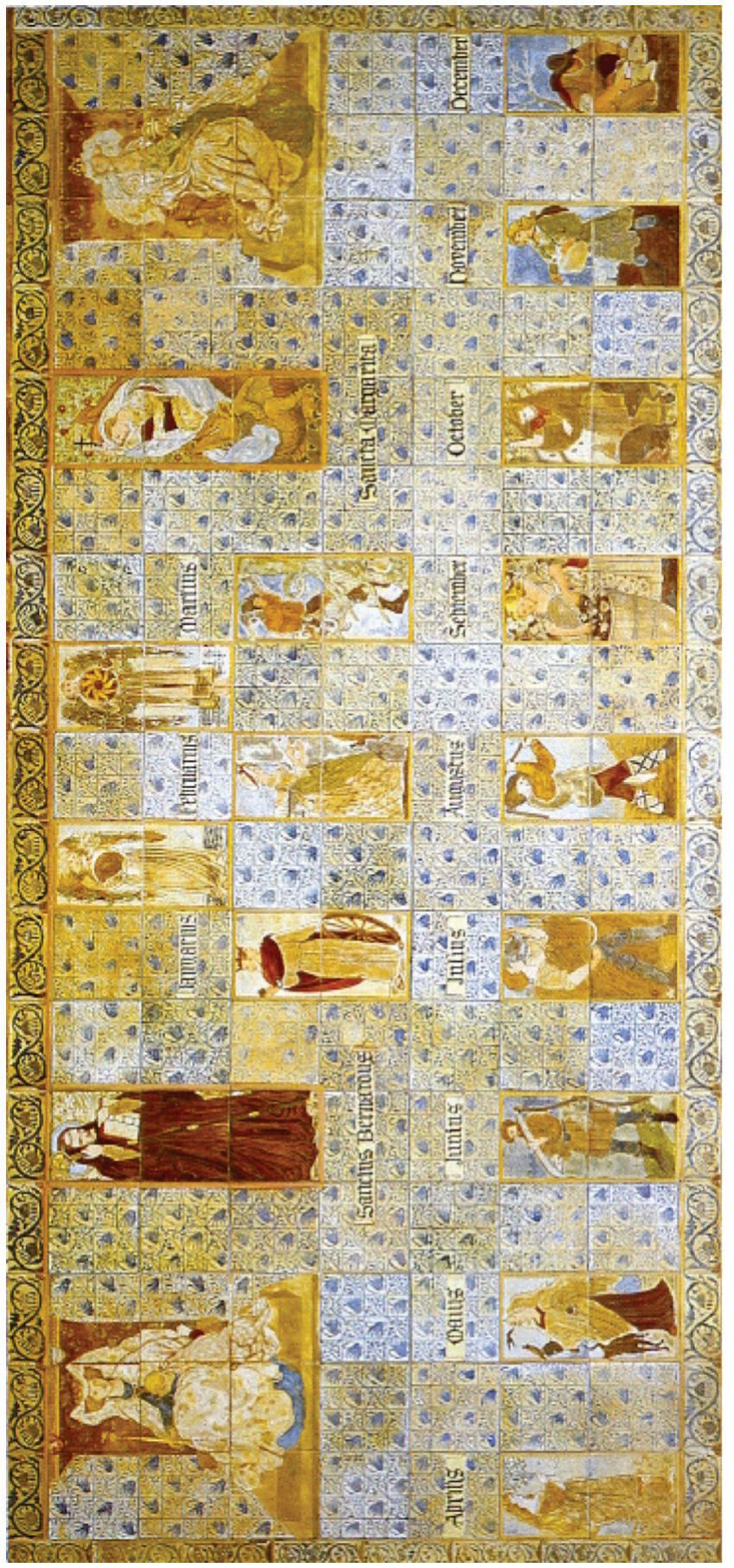

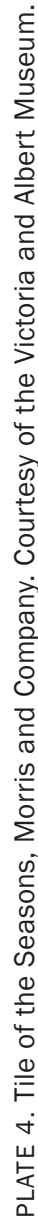




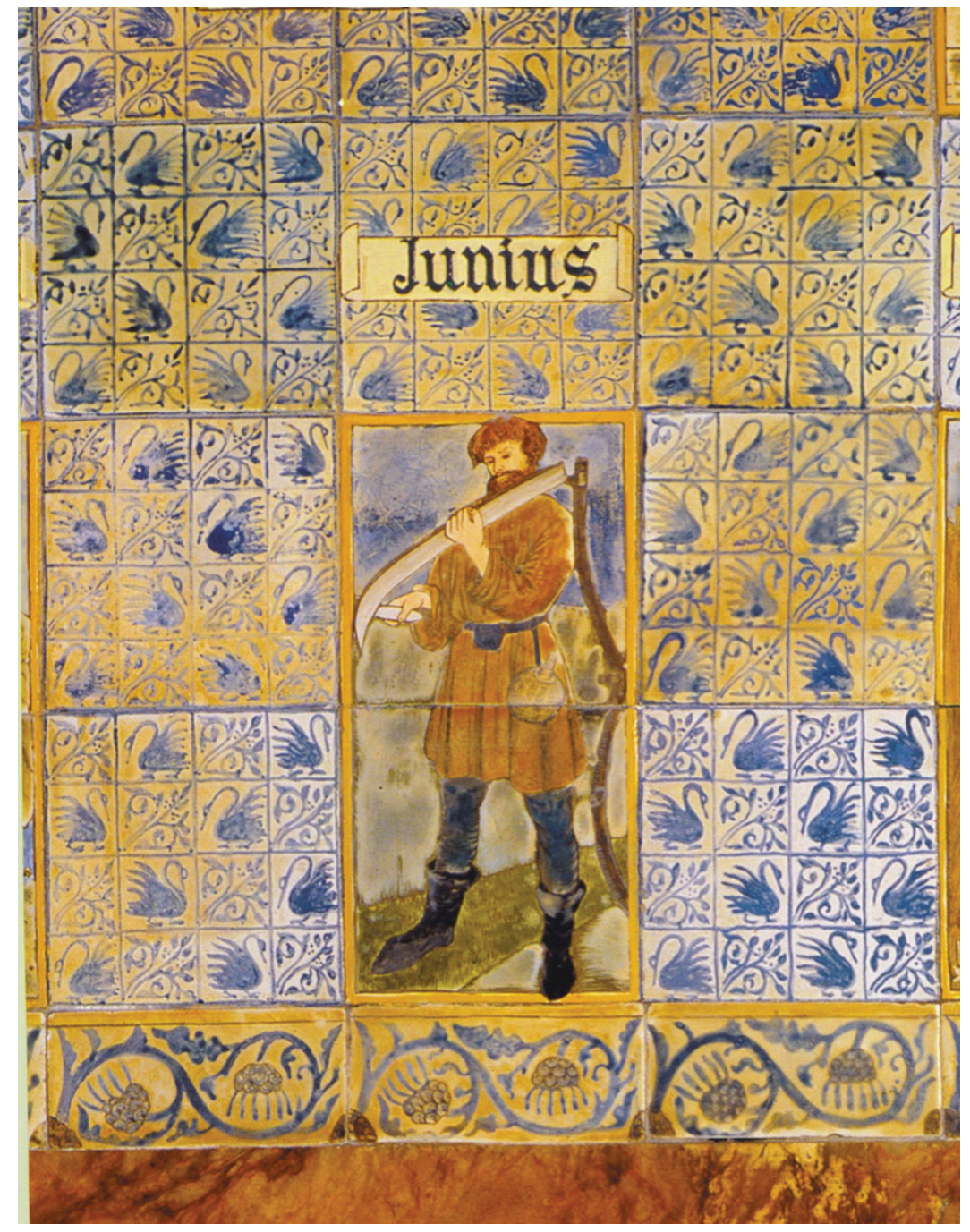

PLATE 5. Harvester, from Tile of the Seasons, Morris and Company. Courtesy of the Victoria and Albert Museum. 


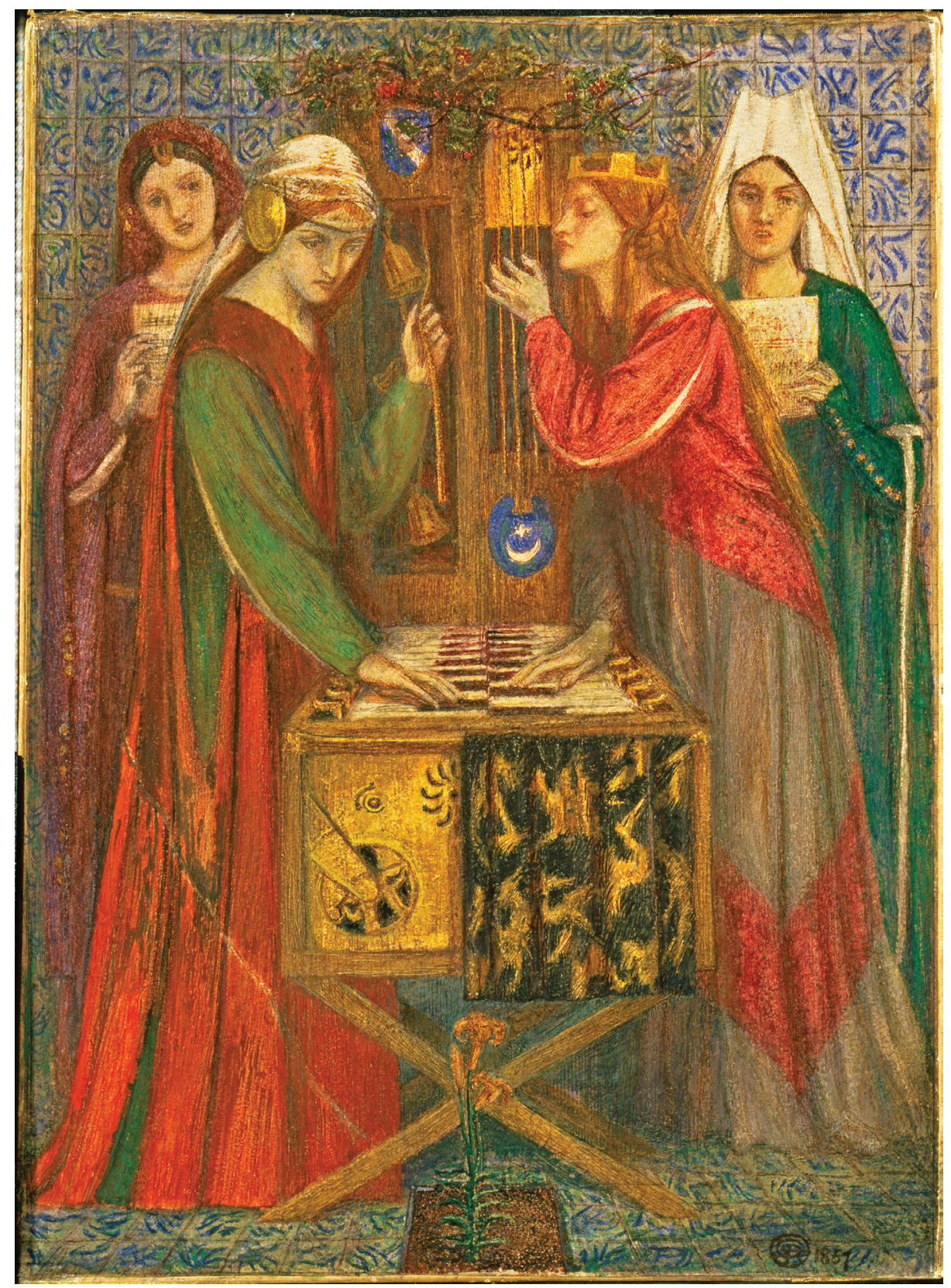

PLATE 6. "The Blue Closet," Rossetti watercolor. Courtesy of the Tate Gallery. 


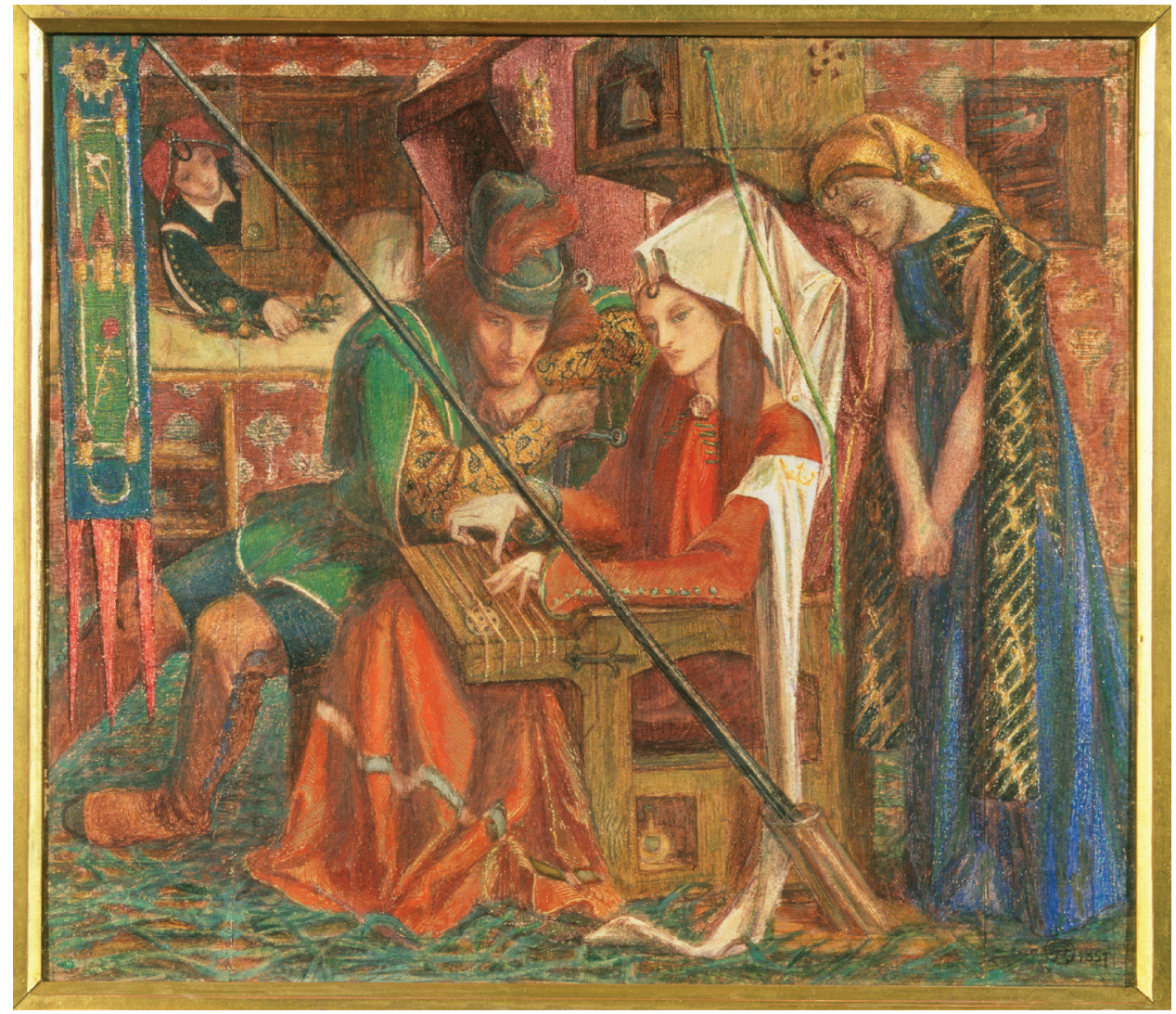

PLATE 7. "The Tune of Seven Towers," Rossetti watercolor. Courtesy of the Tate Gallery. 


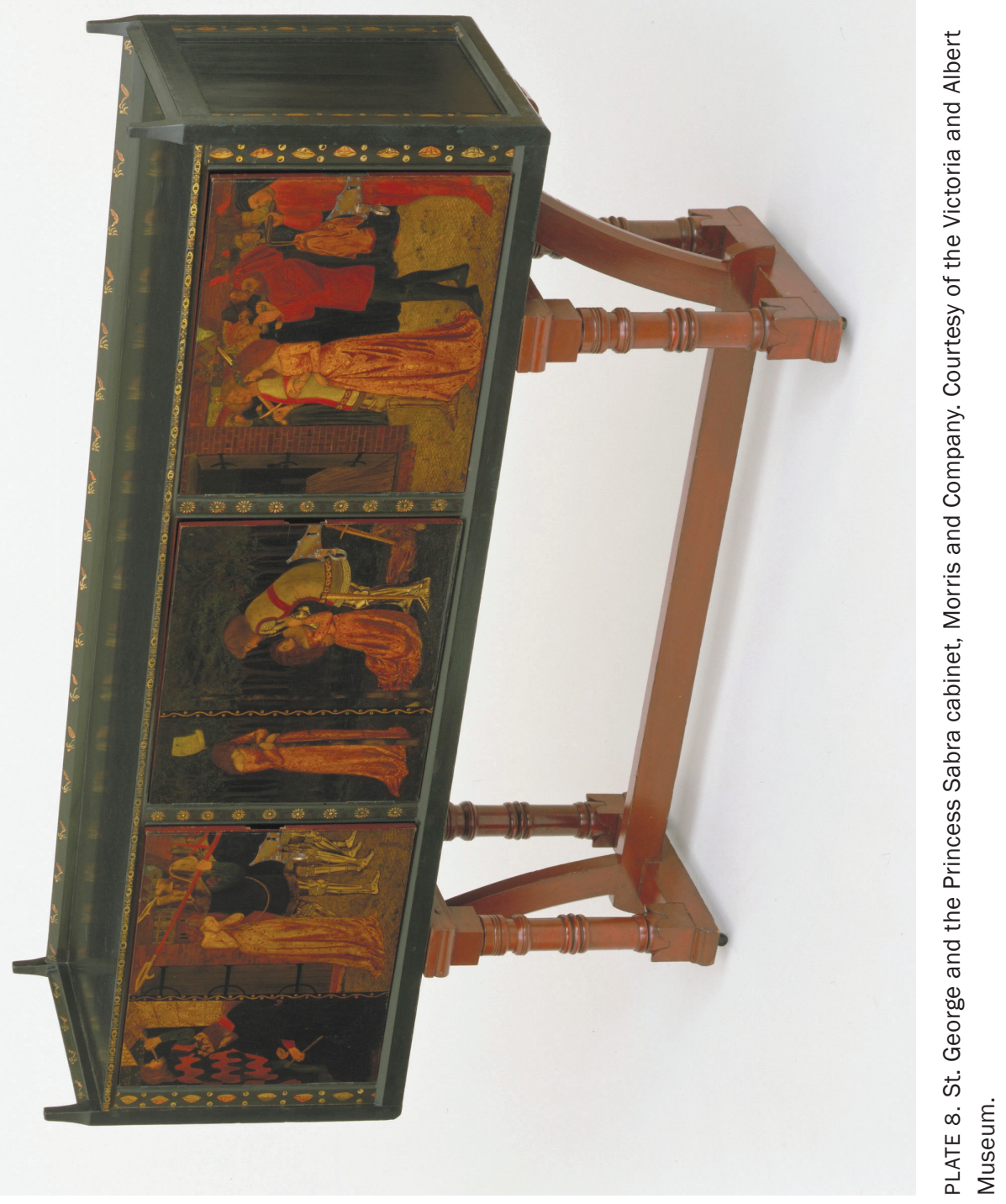




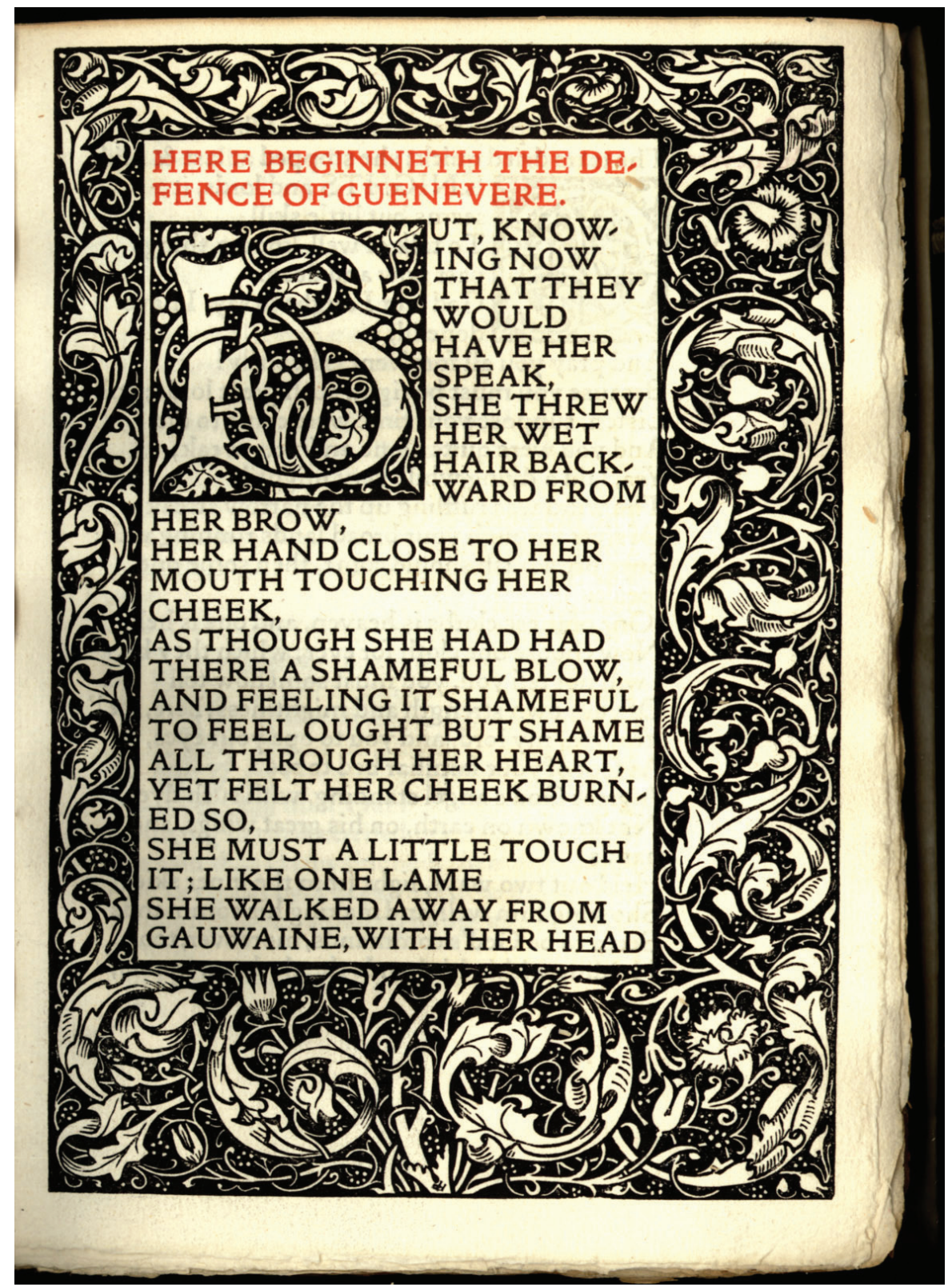

PLATE 9. First page of The Defence of Guenevere, Kelmscott edition, 1892. William Morris Archive, University of lowa Special Collections. 


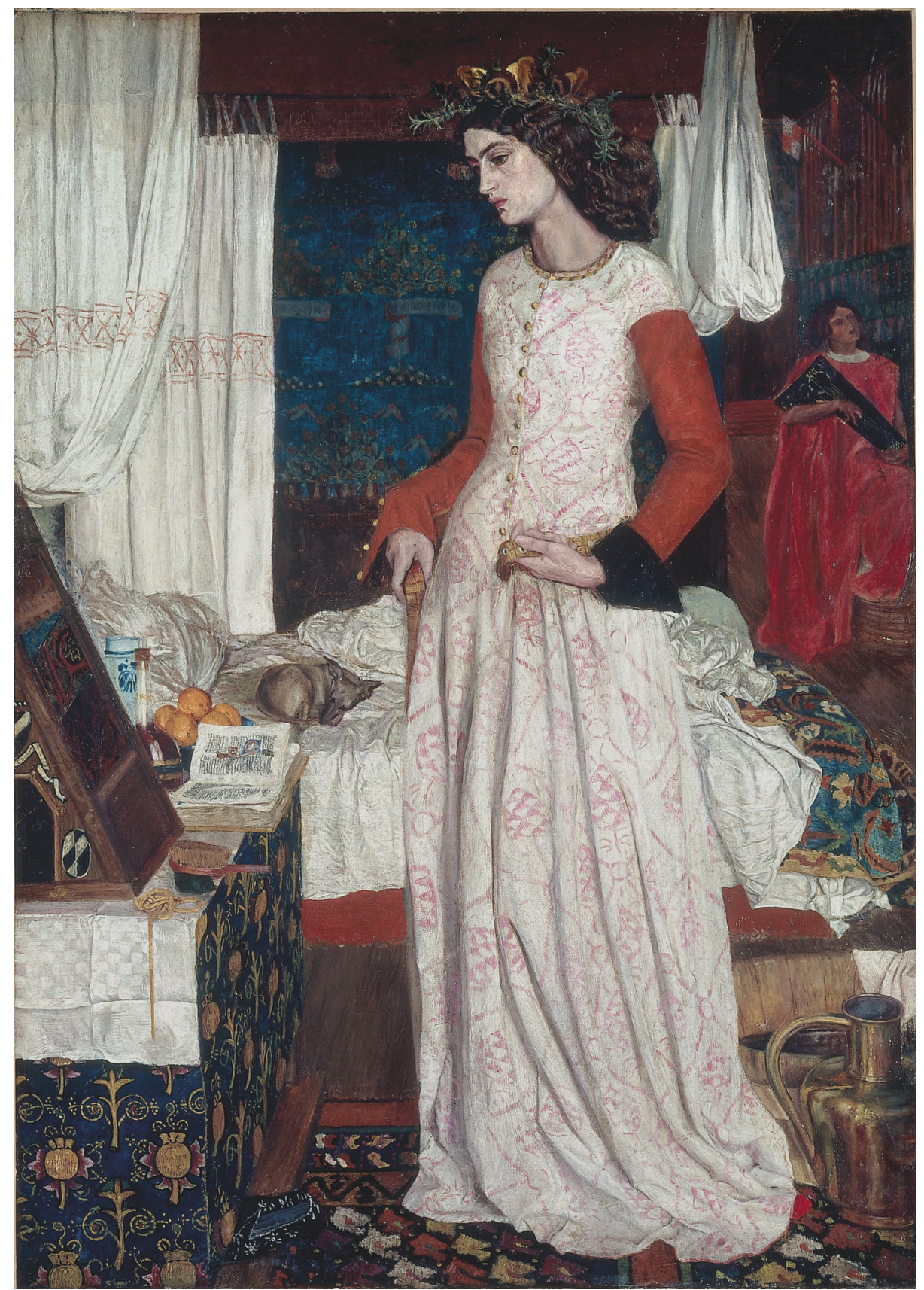

PLATE 10. Morris painting, “La Belle Iseult." Courtesy of the Tate Gallery. 


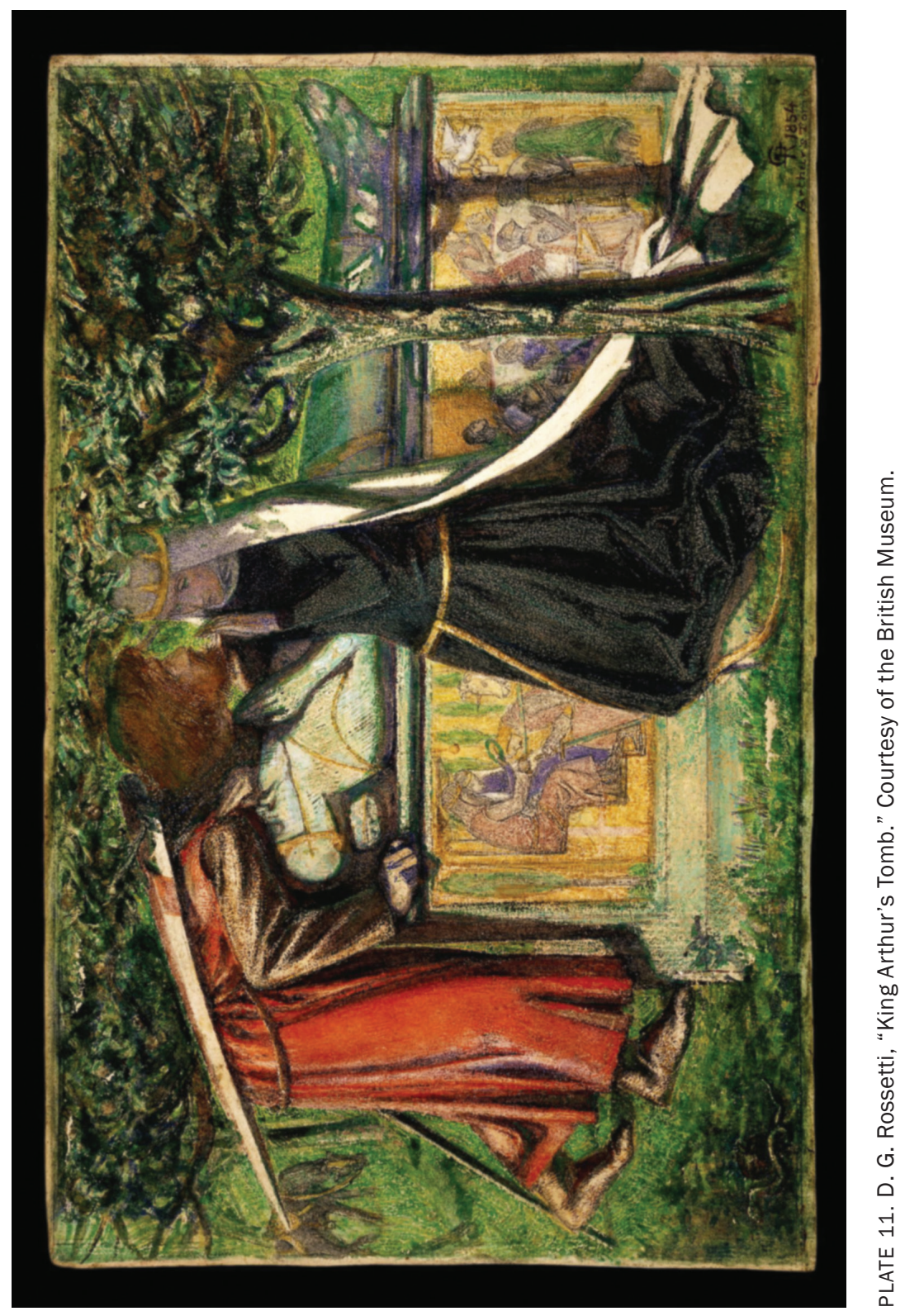




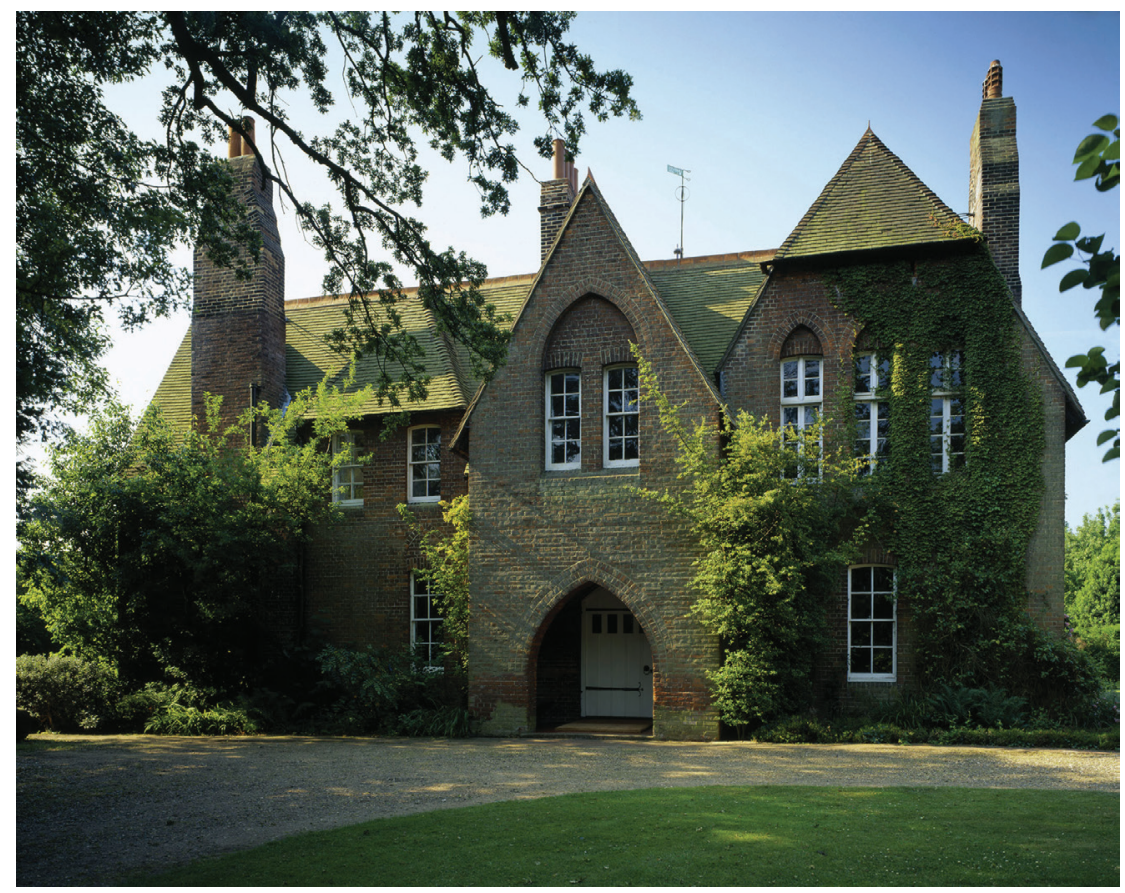

PLATE 12. Red House, front view. Courtesy of the National Trust.

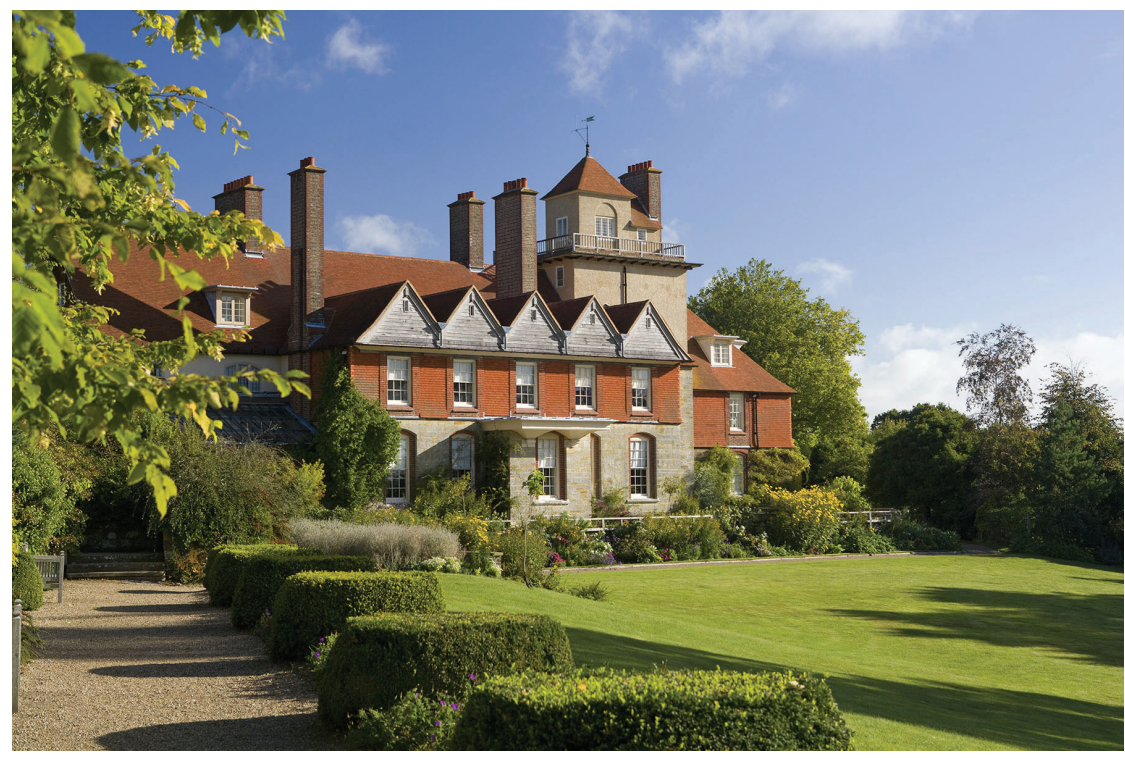

PLATE 13. Red House, back view. Courtesy of the National Trust. 


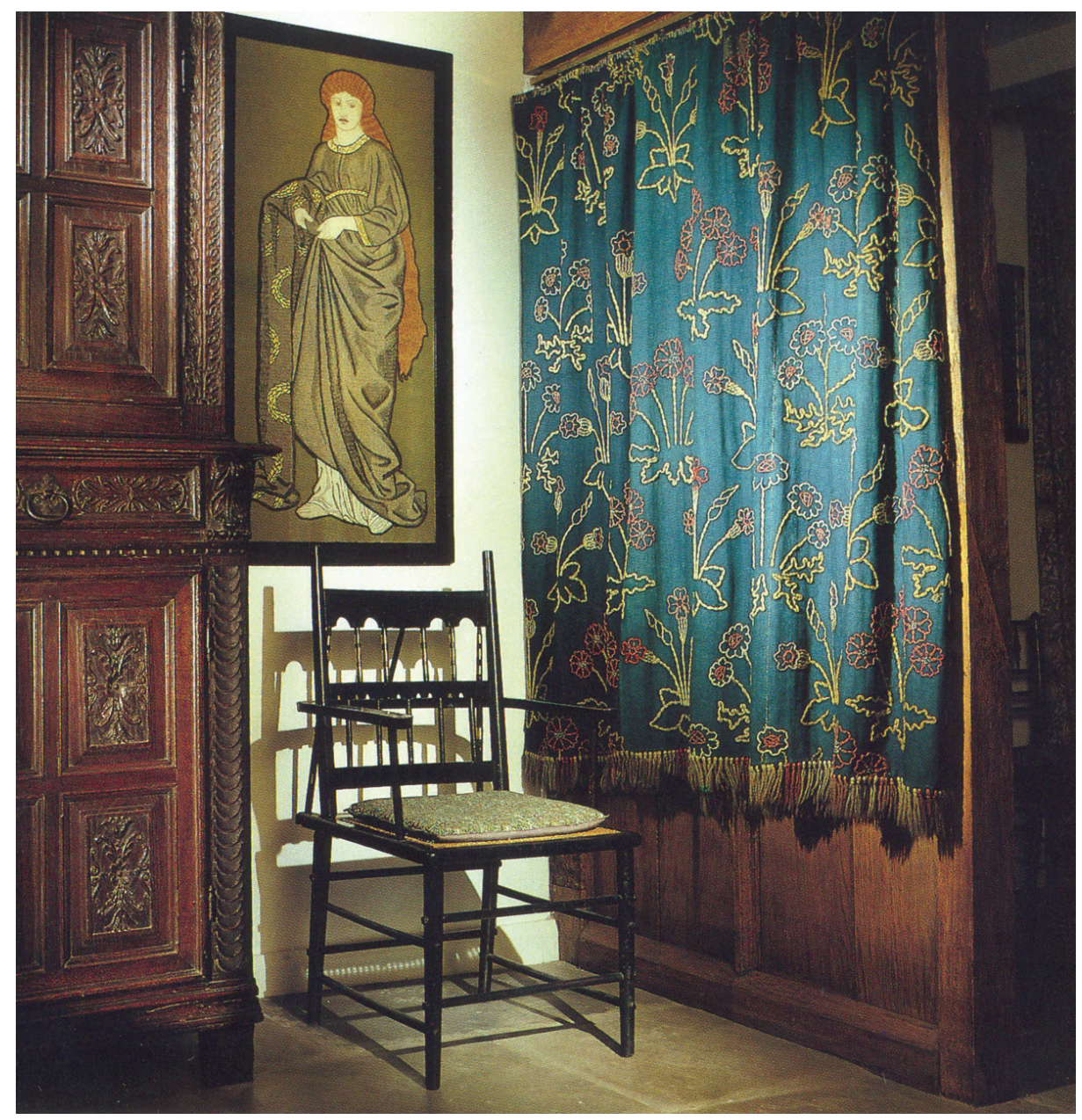

PLATE 14. "Penelope" wall hanging (left) and The Daisy Curtain (right). Photograph by R. G. Wilson. University of Virginia. 


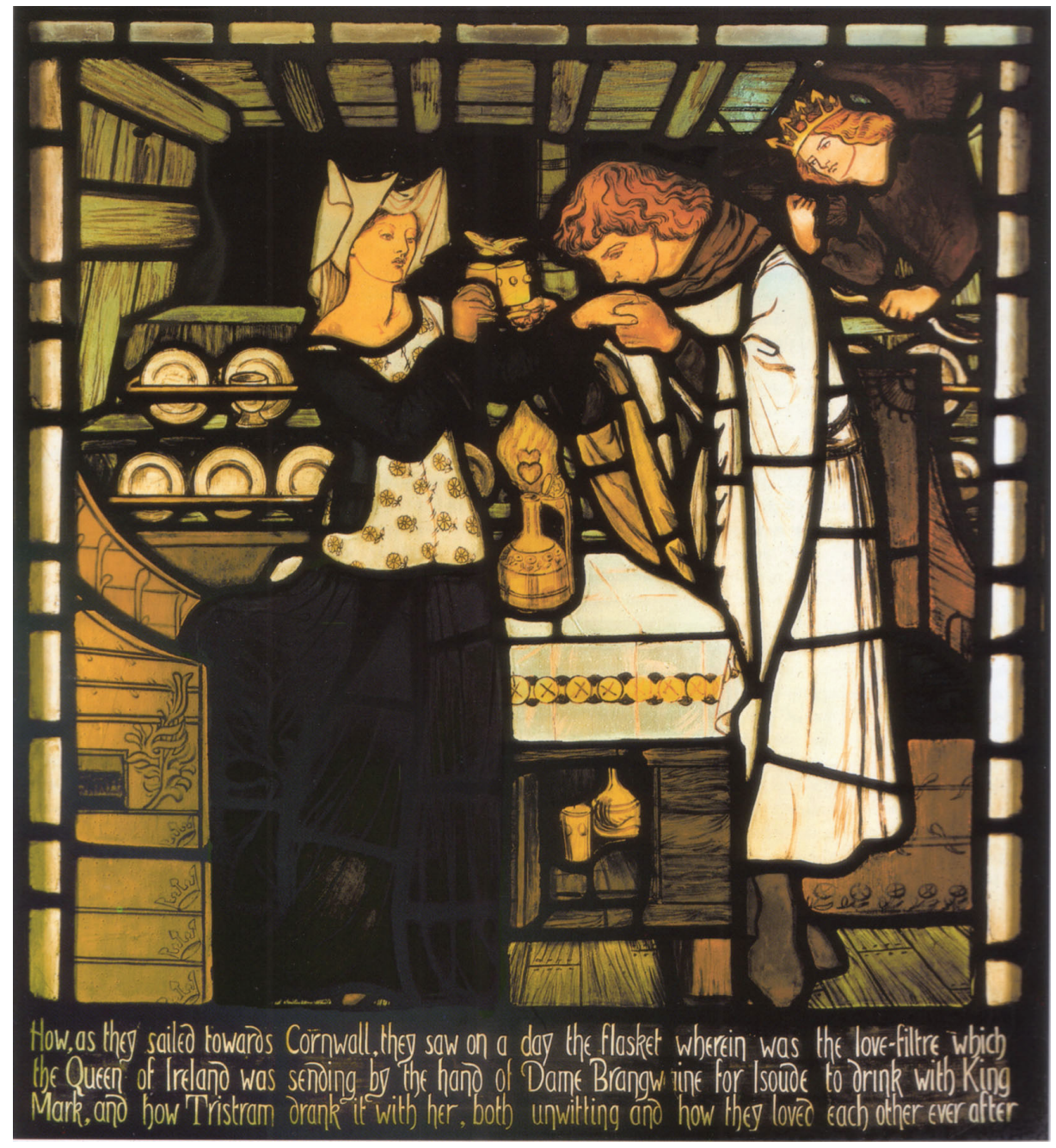

PLATE 15. "Sir Tristram and La Belle Ysoude Drinking the Love Potion," Morris and Company. Harden Grange, Yorkshire. 
-y.

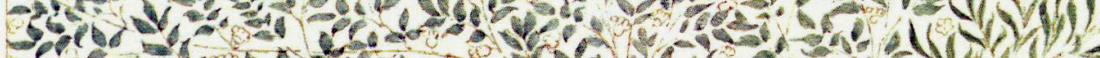

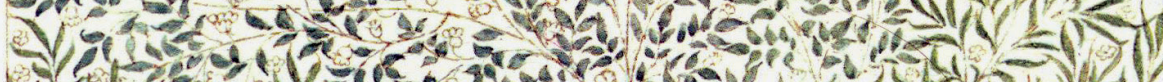

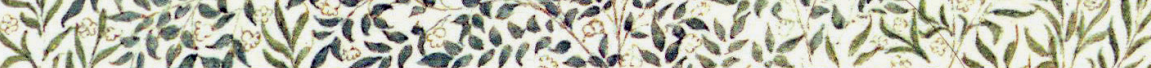
IIIA I) 1 (V)

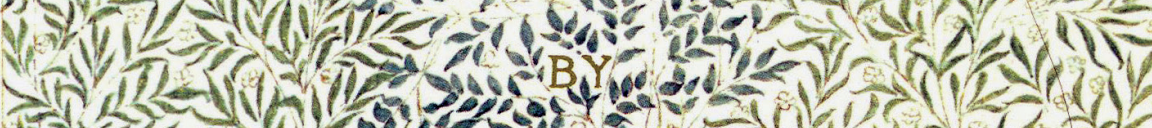
IV

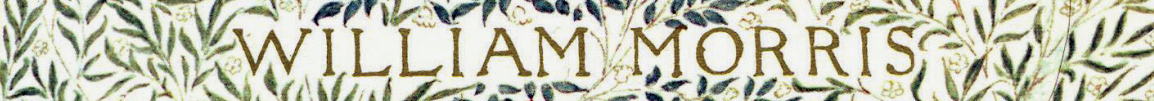

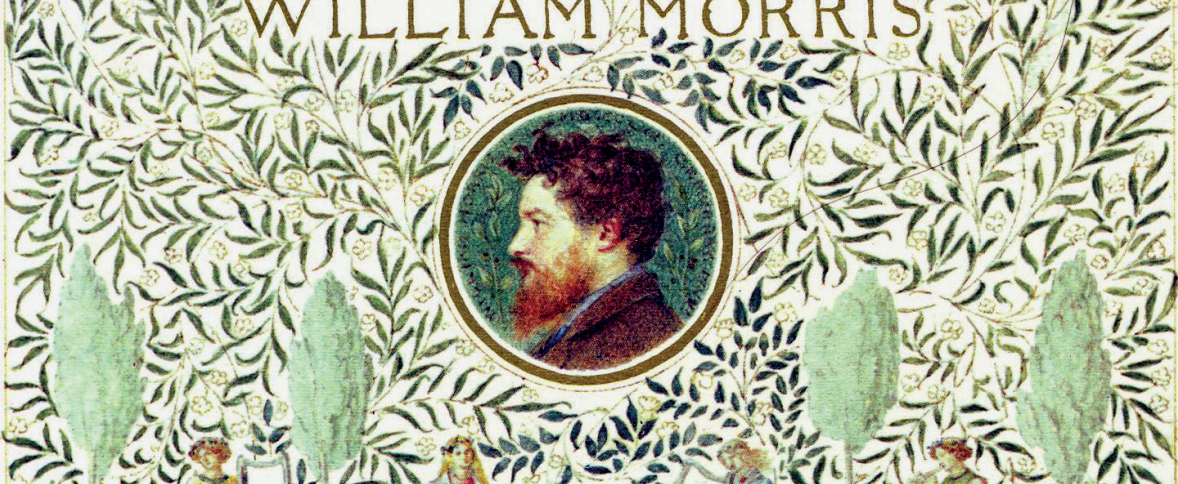

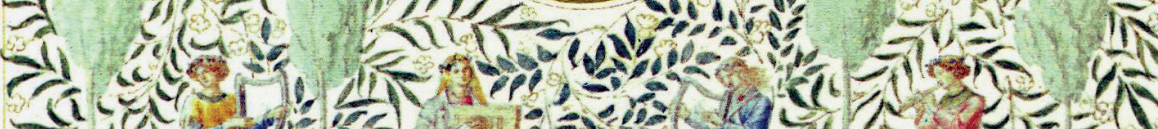

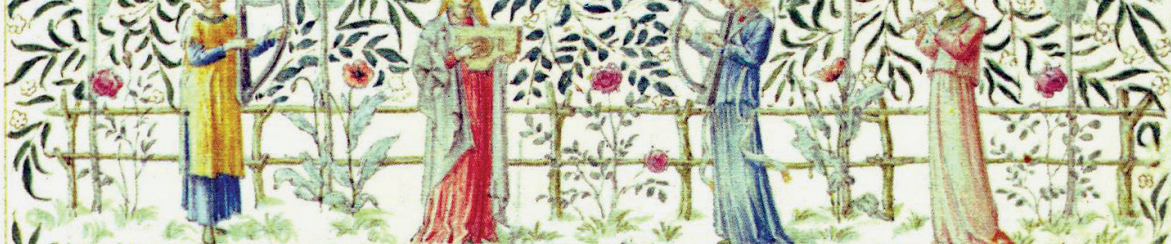

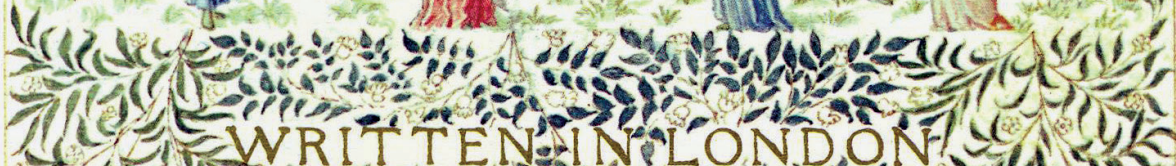

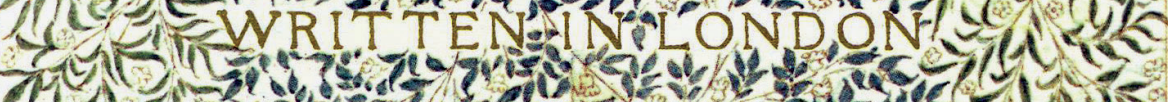

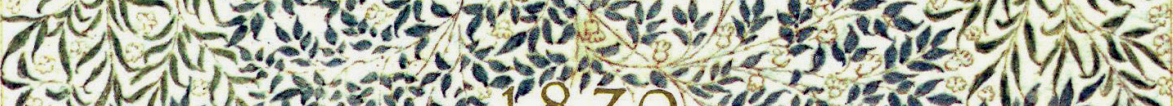

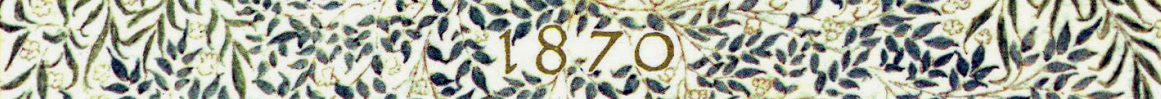

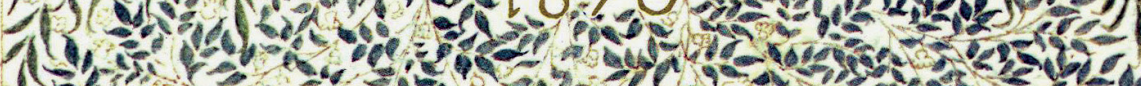

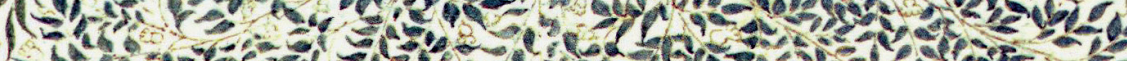

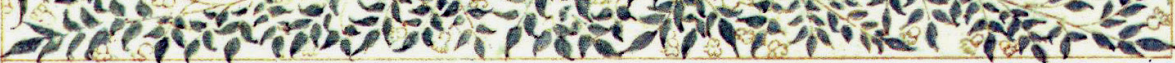

PLATE 16. The Book of Verse, composed and illuminated by Morris, 1870. Courtesy of the Victoria and Albert Museum. 


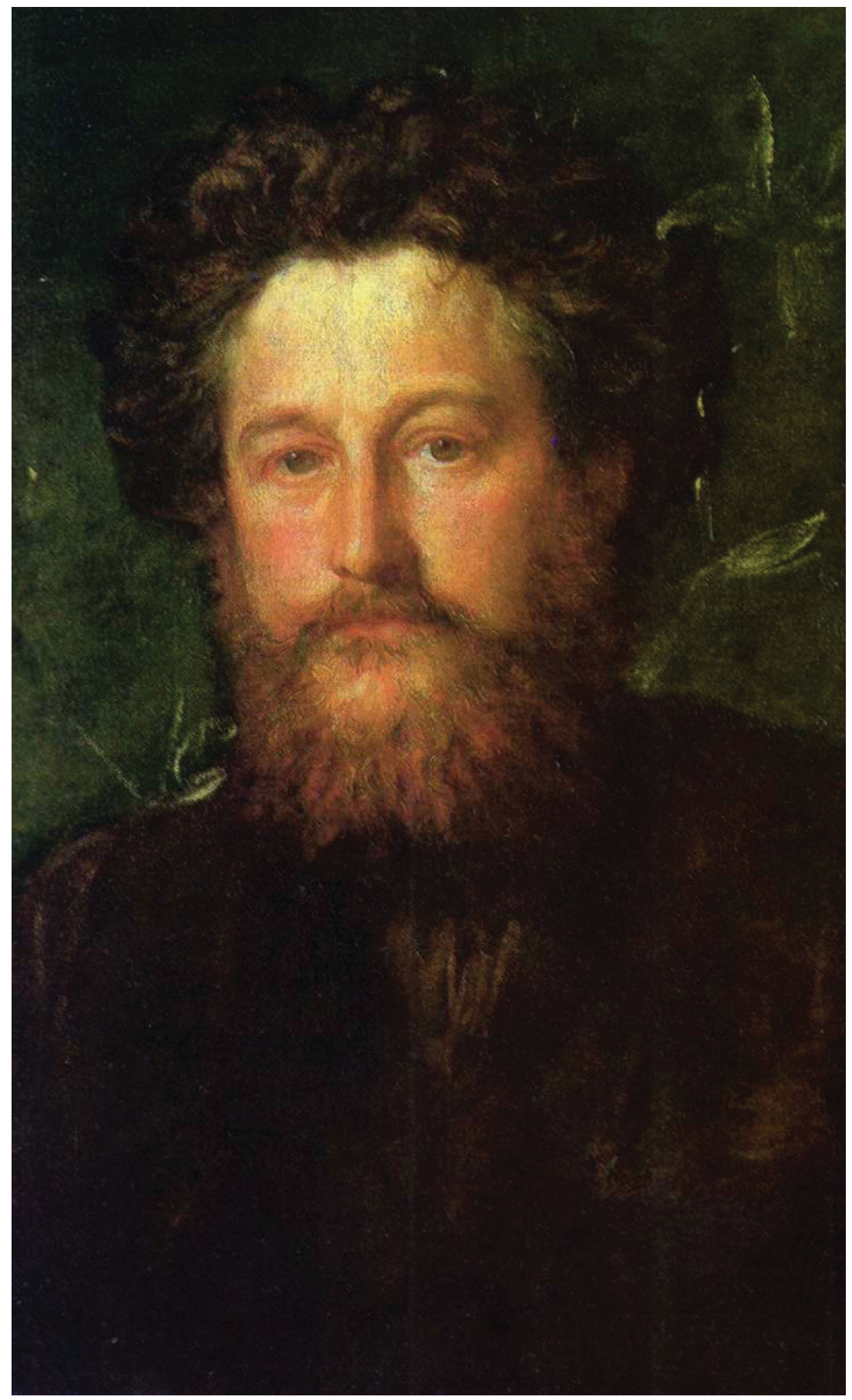

PLATE 17. William Morris by George Frederick Watts, 1870. Courtesy of the National Portrait Gallery. 
he thirty poems Morris published in 1858 as The Defence of Guenevere are among the finest of their period, an even more remarkable achievement when one remembers that its author was twenty-four years old. The passionate directness and psychological subtlety of The Defence startled many of its Victorian readers. Few of Morris's predecessors and contemporaries, for example, had conveyed the nervous, startled qualities of sudden happiness, erotic or otherwise, as acutely as the youthful poet whose Launcelot remembers of Guenevere that

The bell

Of her mouth on my cheek sent a delight

Through all my ways of being; ...

or whose Guenevere exults in the memory of freedom, "shouting, loosed out, see now! All my hair." The Defence poems showed a wide range of narrative technique, plot, language, and point of view, and reflected the creative synthesis of Morris's many tastes-for medieval art and history; tales of folklore, magic, and adventure; and romantic ballads and lyrical poetry fused with an intense subjective imperative, the desire to celebrate beauty and romantic love amid a world of estrangement, failure, and violent death. 
In keeping with Morris's view of narrow-minded elites, The Defence was dismissed by several contemporary reviewers as affected, incoherent, discordant, and without ethical content, and these stereotypes persisted through the early decades of the last century. Victorian critics often equated "moral" concern with didactic and religious fixed ideas which were conspicuously absent in Morris's early work, and when The Earthly Paradise's success spurred reprints of The Defence in the seventies, eighties, and nineties, critics relegated it to a category of colorful but 'primitive' early efforts which offered from time to time, in Pater's words, "a tension of nerve, in which the sensible world comes to one with a brilliance and relief."

Early twentieth-century critics (Dixon Scott for example ${ }^{3}$ ) were more appreciative of the proto-modernist intensity, strange evocativeness, and dramatic force of Morris's early work, but they co-opted its 'ambiguity,' 'irrationality', and 'aestheticism' for their modernist critical ends at the expense of its commemorations of beauty and courage in extremis. Mid-twentieth-century critics tended to damn Morris's 'escapist' poetry with faint praise for his early dramatic monologues, though noting that their speakers lacked the ironies and indirections of Browning's articulate criminals and schemers. In her own 1981 edition of The Defence, for example, Margaret Lourie commended Morris on the grounds that

[the] Guenevere poems ... refused to confront a single moral or intellectual question of their own age or any other. So far from displaying "the powerful application of ideas to life" later recommended by Arnold, they displayed no ideas at all. $(22)^{4}$

She added for good measure that "Like Morris, Yeats refused to compose the Victorian poetry of social responsibility" (22). Such dismissals defined "moral" and "intellectual" in now-dated and tacitly apolitical terms, and a charge that one of the century's most stringent literary critics of social injustice neglected "the poetry of social responsibility" would be an ignoratio elenchi. ${ }^{5}$

1. Eugene LeMire, A Bibliography of William Morris, 8.

2. Review of The Earthly Paradise, Westminster Review, October 1868, no. 90, 300-12.

3. Dixon Scott, "The First Morris," Men of Letters.

4. Margaret Lourie, ed. The Defence of Guenevere; William Morris Archive, http:// morrisedition.lib.uiowa.edu/defenceintro.html\#criticalintroduction.

5. Nor may it have aided Morris's cause that the volume's best-known narrative was that of a condemned Queen. Guenevere was typical of Morris's early heroines in her threatened beauty and passionate temperament, but The Defence volume's male protagonists more often bore the weight of the work's demands for more consistent and scrupulous action. 
In the 'escapist' Defence, for example, Morris depicted a corrupt war-torn society in which women suffered and exhausted men strove for power and position in a 'chivalric' warrior-culture in which ethical coherence was water in the desert. With the exceptions of a few models of kindness and integrity in "Riding Together," "Sir Peter Harpdon's End," "The Haystack in the Floods," "The Chapel of Lyoness" and "A Good Knight in Prison," there was little comradeship or social cohesion in its pages, much less the "fellowship" Morris sought in his work as well as his life. It would be hard to argue that Morris's Defence poems advocated such a world; rather, his enactments are a cry from within.

The Defence did offer some of Morris's most beautiful glimpses of heterosexual affection-the quiet ardor of the speaker who waits for his love's voice or presence in "Summer Dawn," for example, or Guenevere's and Launcelot's nighttime vigil. Most of these moments of tranquil solidarity are blighted by the rigidities of sexual roles in a 'privileged' social order interlaced with treachery, violence, rejection, and imprisonment. Here and at several points in Morris's later work-Scenes from the Fall of Troy, for example, some of the autumn and winter tales of The Earthly Paradise, the first part of Love Is Enough, and several of his essays on art and socialism-he revealed something close to anguish and grief at the betrayals of art and human effort.

His response, present in his letters as well as his works, came in the form of a stoic acceptance of possible failure and willingness to contemplate a life of endeavor without expectation of reward, an emotional counterpart of Keats's "negative capability," which held moral uncertainties in suspension "without any irritable reaching after fact and reason." ${ }^{\prime \prime}$ And part of this stoic resolve was a decision to recreate a bleak and starkly beautiful medieval past, in which good people often perished in misery and "The Wind" offered little hope of consolation.

\section{Oorris and his contemporaries and
Predecessors}

What lay behind the advances in poetic style between Morris's earliest verse efforts and The Defence? Studies of influence and "intertextuality" are a marginal art, but especially relevant to Morris's poetic development during the 1850s, as the young poet learned much from his predecessors and contem-

6. Letter to George and Thomas Keats, 21 December 1817, The Complete Poetical Works and Letters of John Keats (Cambridge: Houghton Mifflin, 1899). 
poraries about the uses of prosody, symbolism, and indirection to produce dramatic effects.

As discussed in chapters 1 and 2, on his way to his Oxford degree Morris - a temperamental autodidact-read widely and freely. He also retained much of what he read, and as in all of his artistic endeavors-from his writing of The Defence and The Earthly Paradise to his designs for the Firm and the Kelmscott Press-he wove its motifs, precedents, and techniques into tapestries of his own. The poets Morris most admired in his youth were Tennyson, Browning, and his somewhat older friend Dante Rossetti. As we have seen, he devoted his sole review for the Oxford and Cambridge Magazine to Browning's Men and Women, ${ }^{7}$ and The Defence was inscribed: "To My Friend Dante Gabriel Rossetti Painter I Dedicate These Poems." (His only other dedication-of The Earthly Paradise-was “To My Wife.") But he also took notice of the work of his now-forgotten contemporary Robert Bulwer-Lytton, as well as the poetry and prose of an American romantic named Edgar Allan Poe, whose complete works appeared in London in 1853.

\section{Ifred Tennyson}

Morris read Tennyson poems before he came to Oxford, ${ }^{8}$ and his college friend R. W. Dixon remarked years later that

it is difficult for the present generation to understand the Tennysonian enthusiasm which then prevailed both in Oxford and the world. All reading men were Tennysonians: all sets of reading men talked poetry. . . . This lasted till "Maud" in 1855; which was his last poem that mattered. ${ }^{9}$

Burne-Jones, a closer friend, recalled that

Morris [read] aloud "The Lady of Shalott" in the curious half-chanting voice, with immense stress laid on the rhymes, which always remained his method of reading poetry, whether his own or that of others. ${ }^{10}$

7. As we have seen, in this he placed Browning "high among the poets of all time, and I scarce know whether first, or second, in our own" (Oxford and Cambridge Magazine, March $1856,171)$.

8. Mackail, Life, 1:38.

9. Dixon, "Memoir," 20-21.

10. Mackail, Life, 1:38. 
And he described his shared enthusiasm when Wilfred Heeley showed them a copy of Tennyson's 1832 Poems ("Mariana in the South" and "The Hesperides" were their favorites). I have already remarked that Burne-Jones's personal reaction to Tennyson hovered somewhere at the margins of veneration ("There are some passages ... accordant to that unutterable feeling ... which Schlegel writes of under the term 'Sighing after the Infinite."” ${ }^{11}$. Morris was more restrained, as Dixon observed many years later:

The attitude of Morris I should describe as defiant admiration . . . . He perceived Tennyson's limitations, as I think, in a remarkable manner for a man of twenty or so. He said once, “Tennyson's Sir Galahad is rather a mild youth." 12 Of "Locksley Hall" he said, apostrophising the hero, "My dear fellow, if you are going to make that row, get out of the room, that's all." Thus he perceived a certain rowdy, or bullying, element that runs through much of Tennyson's work: runs through "The Princess," "Lady Clara Vere" ["Lady Clare de Vere"], or "Amphion."13

He understood Tennyson's greatness in a manner that we, who were mostly absorbed by the language, could not share. He understood it as if the poems represented substantial things that were to be considered out of the poems as well as in them. . . It was this substantial view of value that afterwards led him to admire ballads, real ballads, so highly. ${ }^{14}$

Later readers of Tennyson may forget how many patriotic songs, rhythmic celebrations of military action, and refrains based on women's names he wrote when he was young. His experiments in form and rhythm were what interested Morris, along with his explorations of dreamlike states, his dramatic monologues ("Ulysses" and "Tithonus", for example), ${ }^{15}$ and his use of lyrics in poetic dramas and dramatic medleys such as The Princess and Maud: A Monodrama.

Dixon also recalled that "of the worlds that Tennyson opened in his fragments, [Morris] selected one, as I think the finest and most epical, for special admiration, namely, 'Oriana'”16 — a surprising choice, perhaps, but one which may have appealed to the young Morris for its sonorous refrains, melancholy account of lost love, and setting in a hyperborean medieval "Norland": ${ }^{17}$

11. Georgiana Burne-Jones, Memorials, 1:76.

12. A Morrisian response to Tennyson's Galahad may be found in the Defence's "Sir Galahad: A Christmas Mystery."

13. Dixon, "Memoir," 20.

14. Ibid., $20-21$.

15. Linda K. Hughes, The Manyfaced Glass (Athens: Ohio University Press, 1987), passim.

16. Dixon, "Memoir," 21.

17. Ibid. 
My heart is wasted with my woe,

Oriana,

There is no rest for me below,

Oriana,

When the long dun wolds are ribbed with snow,

And loud the Norland whirlwinds blow,

Oriana,

Morris's “interest in substantial things" had prompted attention to the poem's setting, as Dixon recalled:

He offered the suggestion, and with great force, that the scenery of that matchless "ballad" is not of Western Europe, but South Russian, or Crimean. He held that "the Norland whirlwinds" shewed this: and he had other reasons. $^{18}$

He may also have admired the Defence-like nocturnal assault on a tower in which Oriana had been immured by a stereotypically wicked captor:

She stood upon the castle wall,

Oriana:

She watched my crest among them all,

Oriana:

She saw me fight, she heard me call,

When forth there stept a foeman tall,

Oriana,

Atween me and the castle wall,

Oriana.

"The Lady of Shalott" offered another 'Morrisian' image of a beautiful woman confined in a tower (compare "Rapunzel," "Golden Wings," "Sir Peter Harpdon's End," and "The Doom of King Acrisius"):

Four grey walls, and four grey towers,

Overlook a space of flowers,

And the silent isle imbowers

The Lady of Shalott.

18. Ibid. 
Compare the following passage from "Rapunzel":

When I undo the knotted mass,

Fathoms below the shadows pass

Over my hair along the grass.

$\mathrm{O}$ my golden hair! ...

And yet-but I am growing old,

For want of love my heart is cold,

Years pass, the while I loose and fold

The fathoms of my hair. (11. 17-20, 47-50)

and "A Good Knight in Prison," whose syncopations echoed Tennyson's in "The Lady of Shalott."19

The castle where I dwell, it stands

A long way off from Christian lands,

A long way off my lady's hands,

A long way off the aspen trees,

And murmur of the lime-tree bees. ... (1l. 1-5)

The last moments of Tennyson's eponymous heroine in "Mariana in the South" also resembled the scenes of yearning and comfort at death in Morris's earliest poems:

Large Hesper glittered on her tears,

And deepening through the silent spheres

Heaven over Heaven rose the night.

And weeping then she made her moan,

'The night comes on that knows not morn,

When I shall cease to be all alone,

To live forgotten, and love forlorn.' ("Mariana in the South,” st. 8)

Tennyson's "Hesperides" also employed the Edenic-garden legend Morris included in The Earthly Paradise tale, "The Golden Apples," and its striking colors and incantatory rhythms anticipated counterparts in The Defence:

Number, tell them over and number

How many the mystic fruit-tree holds,

19. Another resemblance may be found in "The Blue Closet," in which "Louise," like the Lady of Shalott, sings mournfully before she leaves her narrow cell to join her lover in death. 
Lest the redcombed dragon slumber

Rolled together in purple folds ...

The world is wasted with fire and sword,

But the apple of gold hangs over the sea. (sects. 2, 4)

In the light of J. W. Mackail's remark that Tennyson's "Oenone" "was a poem for which [Morris] had a boundless admiration," ${ }^{20}$ it may also be of interest that Morris returned to Paris's desertion of Oenone in "The Death of Paris," the September tale in The Earthly Paradise.

Morris's "Gilliflower of Gold," finally, may have owed something to the lyrical rhythms and refrains of the bugle-song from The Princess, one of the Tennyson poems Morris is known to have admired during his Oxford years:

O love, they die in yon rich sky,

They faint on hill or field or river:

Our echoes roll from soul to soul

And grow for ever and for ever.

Blow, bugle, blow, set the wild echoes flying,

And answer, echoes, answer, dying, dying, dying. ("The Bugle-Song,"

st. 3$)^{21}$

A more general Pre-Raphaelite fondness for rich colors and echoing refrains may have reflected Tennyson's influence in more general ways, as Elizabeth Helsinger has observed. Morris sometimes employed such color symbolism to focus on a single resonant image:

Verily then the gold bore through

The huddled spears of the scarlet and blue.... (“Two Red Roses Across the Moon")

More obviously evident in the Defence poems was the influence of Tennyson's recurrent use of Arthurian and Malorian subjects. We have seen ways in which the language and central motifs of "The Lady of Shalott" influenced some of the poems in The Defence. Morris's title poem as well as "King

20. Mackail, Life, 1:208.

21. Morris's poem is less rhapsodically detached but equally celebratory:

Crash! How the swords met, "giroflée!"

The fierce tune in my helm would play,

"La belle! La belle! jaune giroflée!"

Hah! Hah! La belle jaune giroflée. 
Arthur's Tomb" recreated the lovers' trysts also celebrated in Tennyson's short lyric "Sir Launcelot and Queen Guinevere” (1842), in which Guinevere

... seemed a part of joyous Spring:

A gown of grass-green silk she wore,

Buckled with golden clasps before;

A light-green tuft of plumes she bore

Closed in a golden ring.

As fast she fled through sun and shade,

The happy winds upon her played,

Blowing the ringlet from the braid: ... . (11. 23-27, 37-39)

As mentioned earlier, Morris's "Sir Galahad: A Christmas Mystery" offered a more melancholy variant of Tennyson's knight-errant in "Sir Galahad." Tennyson's knight was cheerfully confident, for example:

A maiden knight-to me is given

Such hope, I know not fear;

I yearn to breathe the airs of heaven

That often meet me here. (st. 5)

But Morris' counterpart had to stave off despair:

Night after night your horse treads down alone

The sere damp fern, night after night you sit

Holding the bridle like a man of stone,

Dismal, unfriended, what thing comes of it ... (11. 21-24)

But me, who ride alone, some carle will find,

Dead in my arms in the half-melted snow ... (11. 49-50),

and the modest epiphany at the end of Morris's poem left in suspension whether Galahad actually has achieved the aim of his quest.

Morris's "Rapunzel" also offered an interesting contrast, in this case with Tennyson's 1847 Princess. Tennyson's hero courts a grieving Princess Ida after a melee in which her women's college has been destroyed ("Come down, O maid, from yonder mountain's height”), but Morris's Rapunzel, imprisoned against her will and grateful for release, marvels at the beauties of nature she had long been denied: 
... but is this real grass, love, that I tread upon?

What call they these blue flowers that lean across my feet? (1l. 281-82 $)^{22}$

Tennyson's Maud (1855), finally (Dixon's "last [Tennyson] poem that mattered"23), may have left a fading imprint on other poems in The Defence. Plausible parallels may be found, for instance, between the lurid details evoked by the speaker of Maud and the equally troubled consciousness of the speaker of "The Wind." Compare Tennyson's

I hate the dreadful hollow behind the little wood,

Its lips in the field above are dabbled with blood-red heath,

The red-ribbed ledges drip with a silent horror of blood.... (Maud, 11. 1-3)

with the paranoia of Morris's speaker:

Ah! no, no, it is nothing, surely nothing at all,

22. Other resemblances included the parallels between Morris's "Praise of My Lady" and lifelong interest in the Helen of Troy legend and Tennyson's description of Helen in the 1842 "A Dream of Fair Women":

At length I saw a lady within call, Stiller than chiseled marble, standing there;

A daughter of the gods, divinely tall, And most divinely fair. ...

"I had great beauty: ask thou not my name: No one can be more wise than destiny.

Many drew swords and died. Whereer I came I brought calamity."

To which the narrator/speaker answers gallantly:

"No marvel, sovereign lady; in fair field Myself for such a face had boldly died, ..."

Other parallels may be found between the motifs and settings of Tennyson's "Mariana" and "Golden Wings"; in each a woman waits in a near-deserted mossy building surrounded by bats, a moat, and a garden with poplar trees, and the setting's decay mirrors her final loneliness and defeat. Written in "In Memoriam" stanza form, "Golden Wings" occasionally evokes the latter's hushed, nighttime imagery:

No answer through the moonlit night;

No answer through the cold grey dawn;

No answer when the shaven lawn

Grew green, and all the roses bright.

"Spell-Bound" also contains another possible echo of the biblical reference in "In Memoriam," "He is not here; but far away . . .": "He is not dead, but gone away."

23. Dixon, "Memoir," 20. 
Only the wild-going wind round by the garden-wall,

For the dawn just now is breaking, the wind beginning to fall ...

If I move my chair it will scream, and the orange will roll out far, And the faint yellow juice ooze out like blood from a wizard's jar;

And the dogs will howl for those who went late last month to the war. ("The

Wind," 11. 1-3, 16-18)

Indeed, Maud and "the Wind" may both have owed something to the muchridiculed contemporary "Spasmodics," whose poems were characterized by turbulent plots, 'garish' coloration, sudden discontinuities, roughness of speech, and intensity of small details perceived under stress. ${ }^{24}$

Contrasts may also be found in Morris's variant of the Malorian legendhis lack of interest in the predicament of two women who love the same man, for example. He may have neglected the figure of Elaine because he thought "The Lady of Shalott" had presented its subject as well as could be done, or because he thought that Elaine's devotion would overshadow the 'tragic' love of Launcelot and Guenevere. Also unlike Tennyson, Morris showed little interest in the figure of Arthur, whether as warrior, ruler, or husband.

Thus Morris was clearly intrigued by the decorative imagery, symbolic uses of vivid color, and stylized quasi-medieval reconstructions in Tennyson's poems in the years in which they "mattered," but rejected in the end Tennyson's establishmentarian view of Malorian legend. Historians, he thought, might 'praise famous men and their fathers who begat them,' but poets should honor their brothers and sisters who resisted unnatural restraints or faced the silence of irreversible loss.

\section{Robert Browning}

Morris's The Defence of Guenevere appeared thirteen years after Robert Browning's Dramatic Romances and Lyrics (1845) and three years after Men and Women (1855), and his Victorian critics took unkindly to any resem-

24. Karl Chen, "A Study of the Sources and Influences Upon William Morris's 'The Defence of Guenevere and Other Poems'”; for a discussion of spasmody, see Jerome Buckley, The Victorian Temper (Cambridge, MA: Harvard University Press, 1951) and the special issue "Spasmodic Poetry and Poetics," Victorian Poetry 42.4 (2005), ed. Jason Rudy and Charles LaPorte. An essay on Alexander Smith's poetry appeared in the September issue of the Oxford and Cambridge Magazine, and Sydney Dobell's England in Time of War was reviewed in December. 
blances they found. Richard Garnett, for example, an otherwise sympathetic commentator, remarked that

in Mr. Morris' volume we for the first time trace the influence of Browning on a writer of real original genius, and the result is very curious. . . To describe anyone as Rossetti plus Browning, is as much as to say that he is not a little affected and obscure. ${ }^{25}$

Morris himself acknowledged to a friend that The Defence was "more like Browning than anyone else, I suppose,"26 and years later remarked of the unpublished "The Long Land" ("oh the callowness of it!") that it was "tainted with imitation of Browning, as Browning then was." ${ }^{27}$ Whatever the value of "The Long Land," subsequent readers of The Defence have tended to share J. W. Mackail's view that

[the Froissartian poems] might aptly be headed Dramatic Lyrics and Dramatic Romances of the fourteenth century. The range is much less than Browning; but the intensity of realization is even greater, and it is free from the slightest trace of parade or pedantry. ${ }^{28}$

Most critical discussions of Defence poems (by Laurence Perrine, Carole Silver, Robert Stallman, Amanda Hodgson, and Blue Calhoun, among others) ${ }^{29}$ have essentially agreed.

Morris and his Oxford-era friends, Rossetti among them, were clearly admirers of Browning, a collective view reflected in Morris's 1856 review of Men and Women discussed in chapter 4. Rossetti introduced Morris and Burne-Jones to Browning in 1856, and Burne-Jones later recalled that Robert

25. Literary Gazette, March 1858, xlii, 226-27. Garnett at the time was twenty-four years old, and through his post at the British Library may have become acquainted with William and Dante G. Rossetti, and thus a few of the latter's unpublished poems.

26. Mackail, Life, 1:132. The friend was Mr. J. W. Hoole, the son of a neighbor of the Morrises in Essex.

27. Letter to Charles Murray, 1 May 1891. See the William Morris Archive, http://morrisedition.lib.uiowa.edu/earlypoemsletter.html.

28. Mackail, Life, 1:132.

29. For the literary and personal relationship of the two poets, see Peter Faulkner, "William Morris and Robert Browning." Other discussions of the Defence include Laurence Perrine, "Morris's Guenevere: An Interpretation"; Carole G. Silver, “The Defence of Guenevere': A Further Interpretation"; David Shaw, "Arthurian Ghosts: The Phantom Art of 'The Defence of Guenevere"; Amanda Hodgson, "Riding Together: William Morris and Robert Browning"; Blue Calhoun, The Pastoral Vision of William Morris; Constance W. Hassett, "The Style of Evasion: William Morris's The Defence of Guenevere, and Other Poems"; and David G. Riede, "Morris, Modernism and Romance." For a fuller list, see bibliography. 
and Elizabeth Barrett Browning had praised a Morris poem read aloud to them in the same year..$^{30}$ Mackail remarked that when The Defence appeared,

Browning himself . . . was one of the earliest and the most enthusiastic admirers of this volume. "It has been my delight," he said of it many years afterwards, "ever since I read it." ${ }^{11}$

Browning later praised The Earthly Paradise as well, but in his thanks to Morris for a copy of the latter work recalled his special affection for "Sir Giles' War Song," a relatively simplistic Defence poem that "I used to sing while galloping by Fiesole in old days-'Ho, is there any will ride with me?'"32

Resemblances between Browning's diction and rhetorical features of Morris's Defence are transparent. In the poems of both men, oaths, questions, evasions, repetitions, interruptions, exclamations, digressions, and direct addresses alternate with lyric passages that convey the intensity and bluntness of passion in plausible simulacra of colloquial speech. Compare, for example, the concluding lines of "Fra Lippo Lippi":

And so all's saved for me, and for the church

A pretty picture gained. Go, six months hence!

Your hand, sir, and good-bye: no lights, no lights!

The street's hushed, and I know my own way back,

Don't fear me! There's the grey beginning. Zooks! (11. 388-92)

with Guenevere's artful appeals to her audience in The Defence of Guenevere:

"Being such a lady could I weep these tears

If this were true? A great queen such as I

Having sinn'd this way, straight her conscience sears;

"And afterwards she liveth hatefully,

Slaying and poisoning, certes never weeps,-

Gauwaine, be friends now, speak me lovingly. ..." (11. 145-50)

Concrete descriptions and turns of phrase in The Defence also recalled Browning's work in minor ways. In Browning's "The Statue and the Bust," for

30. Georgiana Burne-Jones, Memorials, 1:108. When Burne-Jones first met Rossetti at the Working Men's College, the latter complained of the biased reviews of Men and Women.

31. Mackail, Life, 1:133.

32. Ibid. 
example, Riccardi's wife admired "the blood ... [which] blues the inside arm" (183), and in "In Praise of My Lady" the object of the speaker's devotion had veins that "along her wrists . . creep, dying languidly . . . / Inside her tender palm and thin" (11. 74-75, 77).

A passage from Morris's "Sir Peter Harpdon's End" also suggests the aspirations of several of Browning's protagonists. Sir Peter declares that

... I like the straining game

Of striving well to hold up things that fall;

So one becomes great. (“Sir Peter Harpdon's End," 11. 218-20),

a more resigned and ethically inflected variant of Andrea del Sarto's recognition that

... a man's reach should exceed his grasp,

Or what's a heaven for? (“Andrea del Sarto," 11. 97-98)

Morris, of course, situated his monologues in medieval England and fourteenth-century Anglo-France, a cruder, more war-torn, and less self-consciously sophisticated society than Browning's Renaissance Italy, but Browning had also set several of his monologues in other reconstructed 'pasts', for example, biblical, English, and French. The "medieval" period for the Victorians began with the fall of Rome and extended well into what we would now call the Renaissance, and Browning's and Morris's settings were also in some respects more cultural and geographical than temporal: Morris gained distance in a still-feudal society, and Browning in ethnic and national boundaries unfamiliar to his British audience. ${ }^{33}$

Each, for example, sought refracting "mirrors" of his own age. Each refrained from excessive idealization or vilification of the past. And eachinspired perhaps by Carlyle's and Ruskin's characterizations of earlier periods-portrayed aspects of these periods that arguably resembled the violence and social turmoil of their own. ${ }^{34}$ Another common trait of Browning's and Morris's dramatic monologues emerged from the attempts to frame characters

33. Several of Morris's dramatic monologues_ "The Haystack in the Floods," "Concerning Geffray Teste Noire," and "Sir Peter Harpdon's End"-also derived part of their force from exact descriptions of disasters or atrocities that may have owed something to counterparts in the work of Browning.

34. As A. Dwight Culler remarked of Browning: he "acknowledged the pride and evil of the Renaissance... [these] were primarily in the late Renaissance, and it was the early period, from the thirteenth through the fifteenth century, that [he] mainly prized . . He preferred a transitional age" (The Victorian Mirror of History, New Haven: Yale University Press, 1985, 217). 
from 'without' as well as 'within' with the aid of internal auditors, observers, and narrators. Morris tempered Browning's ironies with a stronger strain of empathetic identification with observers and observed alike, however, and modulated the stark expressions of Browning's dramatic monologues with a lyricism mostly found in the latter's nondramatic poems.

Morris would also have appreciated the more nuanced and nostalgic frames he found in such works as Browning's "The Flight of the Duchess," in which an aged servant, who in his youth had helped his good-hearted Duchess escape from a tyrannical husband, has worn a plait of her hair for many years, and yearns to know what happened to her before he departs for

... a world where there will be no further throwing

Pearls before swine that can't value them. Amen! (1l. 914-15)

Or "The Toccata of Galuppi," in which an aged speaker regrets the evanescence of physical beauty, a poignant motif that also appears in Morris's "Old Love." ${ }^{35}$

Morris's early divergences from Browning are also characteristic, even telling in mildly surprising ways. None of the Defence speakers is a poet, artist, musician, or connoisseur of such arts (unlike Fra Lippo Lippi, Andrea del Sarto, or Master Hugues of Saxe-Gotha), and the stories and ballads of The Defence have been created in anonymous obscurity. Morris instead describes a lavish variety of folk and narrative art-songs, tapestries, jewelry, funeral statuary, and historical memoirs. Browning worked with the standard assumption that significant art has been and will be created by individual and identifiably "great" artists, musicians, and poets-Fra Lippo Lippi, Master Hugues of Saxe-Gotha, Petrarch in "One Word More." Morris, by contrast, mentioned an occasional craftsman by name (Jacques Picard in "Concerning Geffray Teste Noire"), but was more interested in nameless (or at least unnamed) musicians, composers, craftworkers, and writers of narrative histories. A dramatic instance of this occurs in "Sir Peter Harp-

35. Other motifs in Browning also find scattered counterparts in The Defence. Both poets especially value loyal male comradeship in a worthy cause, and contrast it with counterexamples of betrayal and treachery. In "An Italian in England," for example, Browning's speaker recalls his closest boyhood friend, who has abandoned the cause of Italian nationalism, and Childe Roland remembers the treachery of his two closest comrades as he struggles through the wasteland. Comparable betrayals of friendship and personal loyalty occur in Defence poems such as "Sir Peter Harpdon's End," "The Haystack in the Floods," "Concerning Geffray Teste Noire," "Riding Together," and "Rapunzel," the latter in a starkly familial form: "Oh child, I should have slain my brother, too, / My brother, Love, laid moaning on the grass" (ll. 271-73). 
don's End," in which the poem's unnamed (imagined) maker suddenly breaks through the frame with a poignant plea:

Omnes homines benedicite!

This last fitte ye may see,

All men pray for me,

Who made this history

Cunning and fairly. (11. 744-48)

As might be expected from the ideals Morris had already expressed in "The Shadows of Amiens," "art" in The Defence was essentially what Morris later called "popular art," ornament that "fairly" graced everyday life and recorded the aspirations of its anonymous creators. In keeping with Ruskin's praise for the "signs of the life and liberty of every workman who struck the stone, ${ }^{36}$ he strove to bear witness to the lives of these anonymous craftspeople, in contrast with Browning's disposition to rank-order artists and judge their alleged deficiencies. Consider, for example, the religious painter of "Pictor Ignotus," an unpretentious craftsman whom Morris would almost certainly have treated with fraternal sympathy, but whom Browning presented as a mediocre forerunner of religious naturalism who had taken refuge in "gloom" and querulous obscurity. Morris scathingly dismissed or condemned works he considered blatantly or destructively derivative, but he tended to value the "purity" of a humble painter's untutored style, and believed that all "genuine" art, however limited, expressed human qualities and a measure of spontaneous truth. Correlatively, Morris also had little fear that his truly "popular" art might be suborned to serve evil or manipulative ends (in advertising, for example). In a period strikingly marked by the acquisitions of new-model capitalist "collectors," his entire oeuvre had no analogue of evil aristocratic counterparts such as Browning's wife-murdering Duke in "My Last Duchess," who admired the statue he commissioned of Neptune taming a sea horse; or of the corrupt prelate in "The Bishop Orders His Tomb at St. Praxed's Church," who obsessively discriminated between grades of marble and precious stones.

Browning's criminals tended toward garrulous cunning (e.g., the Duke of "My Last Duchess" or the Bishop of "The Bishop Orders His Tomb"), but Morris's villains were more straightforwardly brutal and tormented souls (Lambert in "Sir Peter Harpdon's End" or Godmar in "The Haystack in the Floods," for example). He also gave them distinctly unequal time, with the

36. Ruskin, "The Nature of Gothic," para. 14, in Rosenberg, ed., The Genius of John Ruskin, 179 . 
exception of the speaker in "The Judgment of God" and the possibly-guilty shadow protagonist of "The Wind," whose plot and irrational intensity recall Browning's "Porphyria's Lover." The latter poem's ending elicited a mixture of shocked sympathy for Porphyria and revulsion at her murderer's deluded brutality, but the horror and desolation of “The Wind" evokes a kind of ambiguous sympathy for its troubled speaker. There are no amusingly odious figures in The Defence-no pickled old monk "In a Spanish Cloister," and a fortiori, no casually anti-Semitic old Bishop who orders his tomb.

What more can be said about the interrelations between Morris's youthful work and Browning's mature poetry? In the 1850s, Morris valued Browning's dramatic monologues as exemplary attempts to tell an interactive story as experienced by its speaker and audiences, and he continued to employ such "internal" narrators in more complex ways in his later work-sometimes several of them in imbricated frames-within-frames-in alternation with other voices that served as more direct projections of their creator's emotions.

Browning also influenced Morris's poetry in ways that extended beyond his choice of specific motifs and the receding ironies of his dramatic monologues. Like Browning, Morris felt contempt for institutionally protected tyranny and admired sensuous beauty, romantic love, and maligned innocence. He also shared an ethos of activism and appreciation of complexity and dissonance, preoccupations that he modulated and sometimes transposed into a relative minor key. Morris had already rejected the growing Puritanism and political conservatism evident in Tennyson's more didactic poems such as the 1842 "A Vision of Sin" and "The Palace of Art," as well as parts of the 1855 Maud. A kind of antipuritanical moralist, Morris became one of the more consistent poetic upholders of a benign aesthetic variant of the Victorian work ethic. As he matured politically he continued to respect Browning's "progressive" assumption that ardent effort can lead to a kind of liberation, and in so doing prepared the way for his later redefinition of "useful" work.

Significant disparities in the two poets' viewpoints and choice of subjects of course remained. Browning's Victorian liberalism in Men and Women retained vestiges of an implied ethic of success, but Morris's protagonists knew better. Their stubborn allegiance to codes of unrecognized effort prepared them for possible failure, and they sometimes did fail. Morris also disregarded many of Browning's characteristic preoccupations-theology; the pursuit of "greatness"; marital discord and criminal psychology; diverse quirks of language and logic-in favor of others: the effects of frustration in love; principled endurance and the worthiness and anonymity of past artistic and other endeavors (whether "great" or not); and the intrinsic pathos and nobility of all causes that were too good not to be "lost." Such differences con- 
tributed to Morris's later decision to forgo the more recognizably Browninglike mannerisms he had cultivated in The Defence.

In History and the Prism of Art: Browning's Poetic Experiments, Mary Ellis Gibson maintained that Browning's major achievements were poetic reflections of a wider contextual view of history as a web of circumstances, and Browning's later dramatic monologues did clearly interpret their incidents within wider social patterns. After The Defence, Morris likewise turned his attention to broader social and aesthetic concerns, among them problems of the selective transmission of history and artistic re-creation. He came to consider history less a "web" than a fragmented palimpsest of significant traces that await the empathetic rediscovery of narrator and reader. He also expressed a variant of this view in The Earthly Paradise's celebrations of failed heroic effort, and drew on it for his growing sympathy with revolutionary aspirations, which found its most poignant historicist expression in A Dream of John Ball.

\section{G. Rossetti}

Not surprisingly, The Defence owes much to the man to whom it was dedicated, "My Friend / Dante Gabriel Rossetti / Painter." Rossetti's influence on the broader patterns of Morris's language was slight, but his interest in ballads and refrains and use of concise, ornate language for his artistic ballads such as “The Bride's Prelude" encouraged Morris's use of similar refrains and stanza forms in his verse. Rossetti also shared Morris's respect for Browning, as mentioned earlier, and he clearly encouraged Morris's use of medieval, chivalric, and Malorian themes.

Rossetti also organized the Oxford Union murals project, which in 1857 brought together Burne-Jones, Rossetti, Morris, Algernon Swinburne, Val Prinsep, Arthur Hughes, Spencer Stanhope, and others to paint scenes from Le Morte D’Arthur. Rossetti had already begun "God's Graal," a poem on Launcelot which he never finished, and in 1855 he completed a watercolor of "King Arthur's Tomb" whose details closely paralleled the incident as presented in Morris's later Defence poem of the same name.

Of the three poems Rossetti contributed to the Oxford and Cambridge Magazine in 1856, two were quasi-medieval in tenor, "The Staff and Scrip" and "The Blessed Damozel," and his five woodcut illustrations to the 1856 Moxon Tennyson included three drawings from Arthurian themes: Sir Galahad; Launcelot looking on the dead Lady of Shalott; and King Arthur and the 


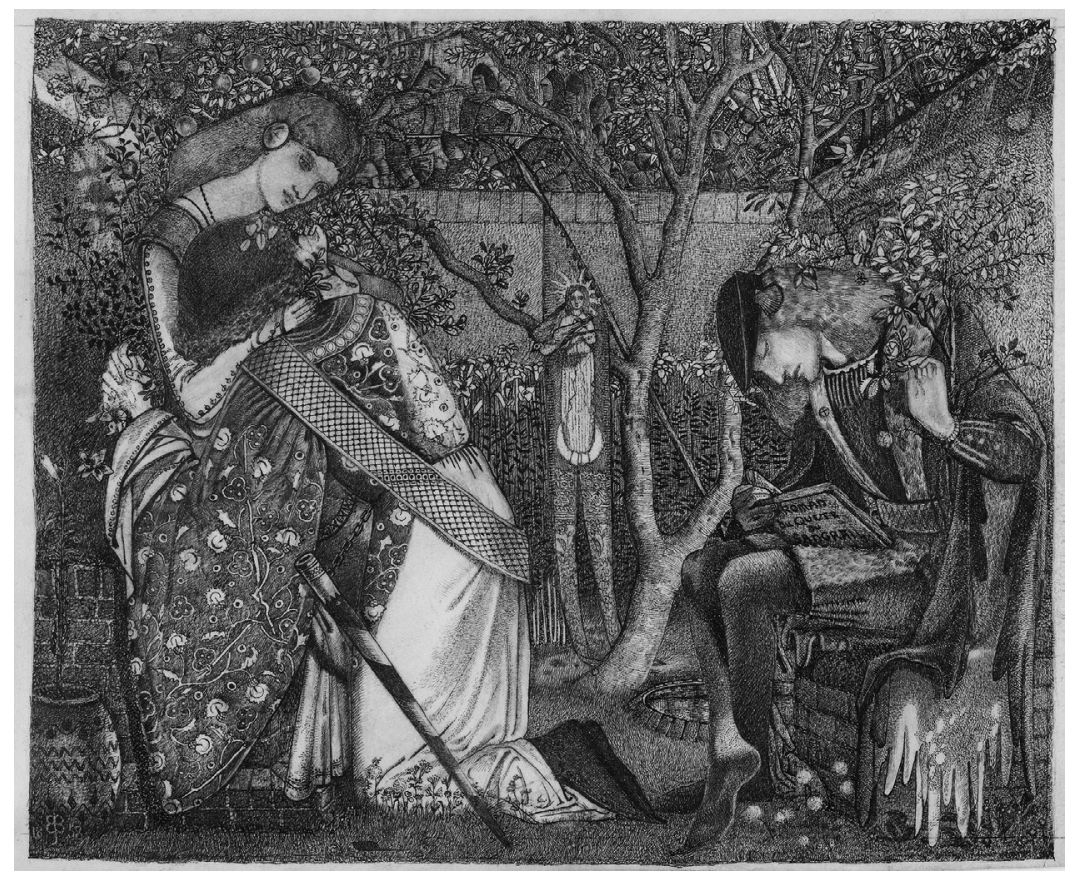

FIGURE 16. Edward Burne-Jones, “The Knight's Farewell." Courtesy of the Ashmolean Museum, Oxford.

Weeping Queens (the latter for “The Palace of Art”). In or around 1857 (the year in which Morris composed much of The Defence), Rossetti also began or completed no fewer than eight drawings or pictures based on Malorian settings or scenes. ${ }^{37}$ Several of these- "Launcelot Escaping from Guenevere's Chamber" and "A Knight Arming, from the Christmas Mystery of 'Sir Galahad," for example-illustrated specific incidents Morris included in The Defence of Guenevere. And two of Morris's most innovative Defence poems,

37. In addition to the three Moxon illustrations, these included "The Chapel Before the Lists" (1857-64), "Lancelot Escaping from Guenevere's Chamber" (1857), "A Knight Arming, from the Christmas Mystery of 'Sir Galahad'" (oil, c. 1857), "Launcelot at the Shrine of the Sanc Grael" (tempera, 1857), "The Tune of Seven Towers" (1857), "The Wedding of St. George and the Princess Sabra" (1857), "The Damsel of the Sanc Graal” (1857), "King Arthur's Tomb" (1855), "Sir Galahad, Sir Bors, and Sir Percival Receiving the Sanc Grael" (1864), and "The Death of Bruese sans Pitié" (1857-65). (H. C. Marillier, Dante Gabriel Rossetti: An Illustrated Memorial of His Life and Art [London: Bell, 1899], 238-39). Arguably the incidents or themes of all but the last were represented in Morris's poetry of the period. 
"The Blue Closet" and "The Tune of Seven Towers," ${ }^{8}$ as well as an uncompleted fragment on St. George and the Princess Sabra, were inspired in turn by "medieval" drawings or watercolors Rossetti completed in 1856 and 1857.

In less concrete terms, the chief effect of Rossetti's example was probably to encourage portrayal of romantic love as a powerful but essentially moral passion. His painting and poetry suggested associations and patterns for "painterly" physical descriptions of beloved women, and most instances of Rossettian diction in The Defence appear in such evocations and descriptions. Guenevere's self-characterization in The Defence's title poem, for example, loosely suggested the first sonnet of Rossetti's "The Choice":

Then loose me, love, and hold

Thy sultry hair up from my face; that I

May pour for thee this golden wine, brim-high,

Till round the glass thy fingers glow like gold. (“The Choice," 11. 3-6)

See through my long throat how the words go up

In ripples to my mouth; how in my hand

"The shadow lies like wine within a cup

Of marvellously colour'd gold; yea now

This little wind is rising, look you up,

"And wonder how the light is falling so

Within my moving tresses. ..." (“The Defence of Guenevere," 11. 230-36)

Other passages evoked the essential situation and ambience of Rossetti's "Blessed Damozel," in which a lover gazed up at a still human but now immortal beloved:

And still she bowed herself and stooped

Out of the circling charm;

Until her bosom must have made

The bar she leaned on warm,

And the lilies lay as if asleep

Along her bended arm. (st. 3)

38. Virginia Surtees, The Paintings and Drawings of Dante Gabriel Rossetti (1828-1882): A Catalogue Raisonné (Oxford: Clarendon, 1971), vol. 1, “The Blue Closet," 50; “The Tune of Seven Towers," 51. 
In the Defence poem "King Arthur's Tomb," Launcelot admired Guenevere, who had "dwelt up in heaven a while ago / and ruled all things but God ...." and the lover in Morris's "Summer Dawn" prayed to his love to look down upon and remember him:

Pray but one prayer for me twixt thy closed lips,

Think but one thought of me up in the stars ....

Speak but one word to me over the corn,

Over the tender, bow'd locks of the corn. (“Summer Dawn," 11. 1-2, 13-14)

Compare also the catalogue of women's names in Rossetti's “The Blessed Damozel":

"We too," she said, "will seek the groves

Where the lady Mary is,

With her five handmaidens, whose names

Are five sweet symphonies,

Cecily, Gertrude, Magdalen,

Margaret and Roslys." (“The Blessed Damozel," st. 18)

with Galahad's vision in Morris's "Sir Galahad: A Christmas Mystery”:

That I may stand so close beneath your brow,

I, Margaret of Antioch, am glad. ...

O Galahad, I, Cecily, am glad. ...

I, Lucy, am most glad. ...

We are most glad, I, Katherine, with delight

Must needs fall trembling. (1l. 167-68, 170, 173, 176-77)

The reddish-haired women of Rossetti's early drawings and paintings were often surrounded by stars, lilies, corn, and swans, and similar ancillary images appeared in The Defence:

Lest your white feet grow muddy,

Your red hair too ruddy. . . . (“Father John's War Song," 11. 11-12)

Gold wings, the short night slips,

The white swan's long neck drips,

I pray thee, kiss my lips. ... (“Golden Wings," 11. 151-53) 
Other Defence passages suggested the mood and ambience of Rossetti's early medievalist narrative fragment "The Bride's Prelude" — shame, lethargy, alienation, and decaying castles-along with its precise evocations of unpleasant detail:

"Yet I grew curious of my shame,

And sometimes in the church,

On hearing such a sin rebuked,

Have held my girdle-glass unhooked

To see how such a woman looked." (“The Bride’s Prelude," 11. 571-75)

For comparison, consider Guenevere's shame in "King Arthur's Tomb":

... if the priest said anything that seemed

To touch upon the sin they said we did,-

(This in their teeth) ... they grew red with shame,

And gazed down at their feet-while I felt sick,

And almost shriek'd if one should call my name. (1l. 317-19, 322-24)

Rossetti's elaborately dressed but miserable protagonist in "The Bride's Prelude" huddled in an alcove, recoiling from each small noise outside. The imprisoned male lover in Morris's "Spell-Bound" imagined that his unhappy beloved was forced to

... lay the samite on her bed

The wedding samite strewn with pearls

Then sit with hands laid on her knees,

Shuddering at half-heard sound of gulls

That chatter outside in the breeze. (11. 24-28)

Collectively, these parallels also marked clear differences of sensibility, as Morris secularized the still-mildly religious associations of Rossetti's artcatholic ethos, and avoided for the most part evocations of 'heaven.' The moralistic streak in Rossetti's early ballads often manifested itself in punitively unhappy deaths of "sinful" lovers, but the ill-fated lovers of Morris's early poetry suffered more from the injustices of others. In these comparatively early poems Rossetti was preoccupied with guilt, regret, and the destructive consequences of sexual acts; Morris, by contrast, was troubled by the needless postponement or frustration of love, and at his bleakest, the fundamental loneliness of desire. 
"O wen Meredith" (Robert Bulwer-Lytton)

Morris, Rossetti, and most of Morris's circle of college friends admired the published work of "Owen Meredith" / Robert Bulwer-Lytton (1831-91), son of the novelist Edward Bulwer-Lytton. The younger Lytton espoused mildly reformist and anti-establishmentarian views, and shared the Pre-Raphaelites' admiration for Keats and Shelley, Tennyson, Robert Browning, Elizabeth Barrett Browning, and other contemporary poets. ${ }^{39}$

Bulwer-Lytton's Clytemnestra, The Earl's Return, The Artist, and Other Poems appeared in 1855 when its author was twenty-four, Morris's age when he published The Defence of Guenevere ${ }^{40}$ three years later. R. W. Dixon later recalled that in 1855 Morris and his Oxford friends admired-after Tennyson's Maud, of course-two works of verse: Alexander Smith's A Life Drama and Robert Lytton's Clytemnestra. ${ }^{41}$ The latter work contained three poems on Arthurian themes, and I believe they provided another relatively little-noticed antecedent for Morris's interest in Malorian subjects and the anxieties and repressions latent in the Arthurian cycle.

Moreover, Lytton's now-obscure work offered a partial model for Morris's more striking evocation of an accused woman's self-defense, and a prototype (in "The Parting of Launcelot and Guenevere") for Morris's portrayal of the two lovers' anguish and misery in "King Arthur's Tomb." ${ }^{+2}$ Morris also shared Bulwer-Lytton's preference for introspective, sensuous, and nonjudgmental interpretations of medieval legend, a preference reinforced in later works such as "Ogier the Dane," "The Hill of Venus," and several other Earthly Paradise tales.

Lytton's early poems manifested an open-mindedness in matters of sexual ethics, which he characterized in letters to his father as a desire to present several sides of an issue without gratuitous censure or prejudgment. This temperamental choice may have diminished the dramatic force of his work for Victorian readers, but its realism and ethical insights anticipated Morris's sys-

39. Robert Bulwer-Lytton later found a substantial readership for his long verse novels Lucille (1860) and Glenaveril (1885), before critics began to dismiss him as an imitative or derivative writer: "the best of mirrors," as one put it (Michael Darling, "Robert Bulwer-Lytton," 108). For a fuller discussion of the relationship between the poetry of Morris and BulwerLytton, see Florence Boos, "William Morris, Robert Bulwer-Lytton, and the Arthurian Poetry of the 1850s."

40. Clytemnestra, The Earl's Return, The Artist, and Other Poems.

41. In his next volume of poetry, The Wanderer (1859), Robert Bulwer-Lytton included several verses on Scandinavian and Near Eastern topics, but Morris seems never to have mentioned him in his later correspondence and probably came to view him as a minor talent.

42. A discussion of Bulwer-Lytton's influence on The Defence appears in Chen, "Sources and Influences," 316-20. 
tematic tolerance in The Defence, as well as the latter's lifelong determination to "think bigly and kindly" 43 about moral and political dilemmas.

Lytton also found it natural to present eloquent and sympathetic female speakers, including women who deserted their families and resisted potential lovers. Lytton's "Clytemnestra” was not exactly a feminist rewriting of Aeschylus, but it recalibrated the scales of judgment to balance the guilt of an arrogant child-murderer against that of his vengeful wife. Lytton's willingness to give women a significant voice in complex emotional verse-narratives also provided models of assertive and expressive women for Morris and other poets of kindred sensibilities.

Rather surprisingly, Morris based none of the four "Malorian" poems of The Defence of Guenevere on an actual scene in Malory, but in each case embedded scenes of his own device in the larger tale, a reflection of his recurrent desire to extend the bounds of recorded history. Especially striking in these works were the scenes of Guenevere's eloquent self-revelations in "The Defence of Guenevere" and "King Arthur's Tomb," highly rhetorical and sometimes inconsistent reflections of the force and presence of her character.

In Malory, by contrast, Guinevere never defended herself in public against the false charge of treason, but sought to persuade Sir Bors or Sir Launcelot to speak in her defense. In particular, Malory's Guenevere offered no narrative account of her life or "defence" of her choices, as she did in Morris's "Defence," and to a lesser degree, in Lytton's "The Parting of Launcelot and Guenevere." The forceful title-figure of Lytton's poem "Clytemnestra" may also have influenced Morris's characterization of Guenevere, especially Clytemnestra's opening soliloquy, in which Agamemnon's wife defends herself against a charge of treasonous disloyalty to her spouse.

In "Clytemnestra" Lytton renamed the central section of the Oresteia, Aeschylus's grim drama of concatenated vengeance ${ }^{44}$ to bring his heroine's actions into sharper relief, and provided a psychologically plausible account of the motives that drove her to murder her estranged and notoriously brutal husband. His Clytemnestra eloquently denounced the emptiness of her marriage to an arrogant tyrant, who had killed his daughter and bled his country in service to a destructive and interminable war. Forthright and consistent, her 'defence' against charges of treason and adultery elicits a measure of sympathy as she opens her soliloquy with a claim that she is essentially "innocent":

43. Letter to Aglaia Coronio, 25 November 1872, Kelvin, Letters, 1:173.

44. The three plays of the cycle are Agamemnon, The Libation Bearers, and The Eumenides. 
Am I not innocent-or more than these?

There is no blot of murder on my brow, Nor any taint of blood upon my robe.

-It is the thought! It is the thought! ... and men Judge us by acts! $(4)^{45}$

In roughly similar terms, Morris's Guenevere defended her love for Launcelot: "Nevertheless you, O Sir Gauwaine, lie, / Whatever happened on through all those years, / God knows I speak truth, saying that you lie" (11. 142-44).

In another passage that strongly anticipated other aspects of Guenevere's "Defence," Clytemnestra evoked the deep emotional void that led her to love a man who was not her husband:

My soul was blind, and all my life was dark,

And all my heart pined with some ignorant want.

I moved about, a shadow in the house,

And felt unwedded though I was a wife;

And all the men and women which I saw

Were but as pictures painted on a wall: ... (46-47)

Compare Guenevere's wretched weight of "Arthur's great name and his little love" and obligation to be "stone-cold forever" (1l. 83, 88).

Similarly, Clytemnestra remembered Aegisthus's love, which brought her the first warmth of her life:

O what a strength was hidden in this heart!

As, all unvalued, in its cold dark cave

Under snow hills, some rare and priceless gem

May sparkle and burn, so in this life of mine

Love lay shut up. (46)

Contrast in this case Agamemnon's response to her welcome on his return after a ten-year absence: "Women ever err by over-talk. Silence to women, as the beard to men, / Brings honor" (74).

Like Guenevere and Lady Alice in "Sir Peter Harpdon's End," Clytemnestra also bitterly lamented her powerlessness:

45. Page numbers are from the 1855 Chapman and Hall edition. 
O fate, to be a woman! To be led

Dumb, like a poor mule, at a master's will, And be a slave, tho' bred in palaces,

And be a fool, tho' seated with the wise-(51)

Another of Lytton's surprisingly feminist motifs was Clytemnestra's identification with Helen (a favorite heroine of Morris) and the fates of "all whose lives I learn'd," expressed in words that anticipated (and may have influenced) Amy Levy's "Xantippe” (1881):

And though I saw

All women sad-not only those I knew,

As Helen ...

Not only her, but all whose lives I learn'd,

Medea, Deianeira, Ariadne,

And many others-all weak, wrong'd, opprest,

Or sick and sorrowful, as I am now-

Yet in their fate I would not see my own. . . . (“Clytemnestra," 36-37)

Some of these grievances were expressed more sparely by the heroine of Aeschylus's play, but Bulwer-Lytton addressed them in stronger terms to a reformist Victorian audience well aware of the marital abuses publicized in the years preceding the Matrimonial Causes Act of 1857. The self-serving egotist Aegisthus was no Launcelot, of course, and Guenevere's "crime" was adultery, not murder. Morris also went out of his way to focus on Guenevere's fond memories of Launcelot's past devotion, and her conviction that love is a natural and essential part of the cycle of life.

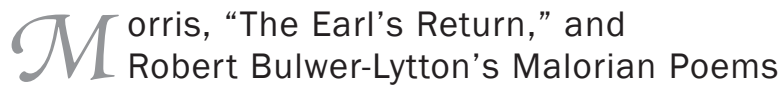

“The Earl's Return," a ballad of revenge and frustrated love, evinces more formal unity than the other, more derivative short poems in the Clytemnestra volume. The poem owed something of its onomatopoeic shifting rhythms and pointed psychological imagery to the example of Tennyson's "Maud," and its expressive lyricism effectively complemented its harsh folktale frame. R. W. Dixon recalled that Morris was delighted by “The Earl's Return," "especially 
... the incident of the Earl draining a flagon of wine, and then flinging it at the head of him that brought it." ${ }^{36}$

Other passages of "The Earl's Return" are reminiscent of scenes in The Defence in which Peter's Lady Alice, Rapunzel, and Jehane of "Golden Wings" await their lovers in their castles and towers, and one brief section in "The Earl's Return" may have anticipated the situation and simple balladic rhythms of "The Blue Closet":

Alice the Queen, and Louise the Queen,

Two damozels wearing purple and green,

Four lone ladies dwelling here

From day to day and year to year;

And there is none to let us go;

To break the locks of the doors below,

Or shovel away the heaped-up snow;

And when we die no man will know

That we are dead. ... (“The Blue Closet," 11. 16-24)

In “The Earl's Return," the Earl's wife

... lived alone, and from year to year

She saw the black belt of the ocean appear

At her casement each morn as she rose; and each morn

Her eye fell first on the bare black thorn,

This was all: nothing more: or sometimes on the shore

The fishermen sang when the fishing was oer;

Or the lowing of oxen fell dreamily,

Close on the shut of the glimmering eves,

Thro' some gusty pause in the moaning sea,

When the pools were splashid pink by the thirsty beeves. (146-47)

As the poem continues a sense of dread gradually emerges, and when the Earl finally returns, mounts the stairs, and embraces his wife, she expires in his arms. Their fatal reunion anticipated not only "The Blue Closet" but also "The Raven and the King's Daughter" (1872), in which Morris's princess, imprisoned in a tower, dies when her lover nears.

Lytton's poem ended with a melodramatic twilight-of-the-minor-nobility

46. Dixon, "Memoir," 22. 
scene in which the wife's erstwhile admirer torched the castle, the Earl, and all his retainers therein. Lytton depicted this conflagration with the metrical equivalent of cinematic special effects, with a result that harked back to the innbrenna-scene Morris later admired in the Njálssaga, and anticipated Morris's subsequent evocation of the horrendous fires that concluded his Sigurd the Volsung.

Lytton's Clytemnestra volume also included "Queen Guenevere," "Elayne Le Blanc," and "The Parting of Launcelot and Guenevere," three blank-verse poems on Malorian subjects. "Queen Guenevere" (whose unusual orthography may have provided a template for Morris's usage) described the queen's beauty in the mode of Enobarbus's descriptions of Cleopatra, as a minstrel sings the refrain, "Si douce, si douce est la Margarete!" (compare "Ah! Que'elle est belle La Marguerite" from The Defence's "The Eve of Crècy"). In "Elayne Le Blanc" - a more finished work that may have been based on "The Lady of Shalott" - another minstrel sings of love in lyrics that recalled Tennyson's "Mariana" and "The Lotus Eaters," and that may have suggested parts of "The Blue Closet."

"The Parting of Launcelot and Guenevere" was a more accomplished and arresting work, and an argument can be made that Morris's "King Arthur's Tomb" recasts nuances and incidents that Lytton presented in simpler and more conventional form. The most striking parallels were found in Lytton's original invention of a private farewell between Launcelot and Guenevere, his preoccupation with the attachment of two deeply devoted lovers frayed by great external stress, and his evenhanded consideration of their complex and sometimes opposing points of view.

The only important plot-element in Morris's poem that had no antecedent in Lytton's work was the setting of the scene at Arthur's tomb, whose lineaments, as we have seen, might have been suggested by Rossetti's 1857 watercolor of “King Arthur's Tomb." In Bulwer-Lytton's “The Parting of Launcelot and Guenevere," for example, Guenevere recounts her sleepless night before his arrival at Glastonbury.

And oft, indeed, to me

Lying whole hours awake in the dead nights

The end seems near, as tho' the darkness knew

The angel waiting there to call my soul

Perchance before the house awakes; and oft

When faint, and all at once, from far away,

The mournful midnight bells begin to sound

Across the river, all the days that were 
(Brief, evil days!) return upon my heart,

And, where the sweetness seem'd, I see the sin.

For, waking lone, long hours before the dawn,

Beyond the borders of the dark I seem

To see the twilight of another world

That grows and grows and glimmers on my gaze.... (249-50)

Her language suggests the dying prelate's speech in Browning's "The Bishop Orders His Tomb" (which also appeared in 1855), and more immediately Guenevere's opening appeal in "The Defence":

"Listen, suppose your time were come to die,

And you were quite alone and very weak;

Yea, laid a dying while very mightily

"The wind was ruffling up the narrow streak

Of river through your broad lands running well;

Suppose a hush should come, then some one speak: ... .

"A great God's angel standing, with such dyes

Not known on earth. ..." (1l. 16-21, 28-29)

"King Arthur's Tomb" opens similarly, with an account of Launcelot's sleepless night as he rides to Glastonbury, and Guenevere's sleepless agitation

As she lay last night on her purple bed,

Wishing for morning, grudging every pause

Of the palace clocks, until that Launcelot's head

Should lie on her breast, with all her golden hair

Each side-when suddenly the thing grew drear

In morning twilight, when the grey downs bare

Grew into lumps of sin to Guenevere. (11. 134-40)

Understandably, the frustration of Lytton's Queen sometimes dissolves into distracted exasperation:

Half in tears

She ceased abrupt. Given up to a proud grief,

Vex'd to be vext. With love and anger moved, 
Love toucht with scorn, and anger pierced with love.

About her, all unheeded, her long hair

Loos'd its warm, yellow, waving loveliness ... (11. 250-51)

In “The Defence," Morris's Guenevere regrets that her griefs had made her seem "cold and shallow without any cloud" (1. 79), and in "King Arthur's Tomb" she apologizes for her heedlessness:

"Alas, my maids, you loved not overmuch

Queen Guenevere, uncertain as sunshine

In March; forgive me! For my sin being such,

About my whole life, all my deeds did twine,

“Made me quite wicked. . .." (1l. 297-301)

In Morris's redaction of the legend, she also offers a parallel account of herself from within:

"Oh, but your lips say, 'Yea, but she was cold

Sometimes, always uncertain as the spring;

When I was sad she would be overbold,

Longing for kisses; when war-bells did ring,

"The back-toll'd bells of noisy Camelot-" (11. 265-69)

In both men's versions, Launcelot's desire and affection are proof against her "wickedness." In “The Parting," for example, he responds:

"'Tho' thou be variable as the waves,

More sharp than winds among the Hebrides

That shut the frozen Spring in stormy clouds,

As wayward as a child, and all unjust,

Yet must I love thee in despite of pain,

Thou peerless Queen of perfect love! ...

Thou goddess far above

My heart's weak worship! So adored thou art. . ." (256-57)

The language of Lytton's poem is more conventional, but the similarities in the poems' 'arguments' and emotional appeals are quite marked. In both versions, both lovers struggle with recrimination and reaffirmation, both stagger or fall from the intensity of their grief, and both poems conclude with a scene in which a solitary, nearly unconscious lover earnestly tries to pray. In 
"The Parting of Launcelot and Guenevere," Guenevere faints after Launcelot departs:

suddenly all

The frozen heights of grief fell loosed, fast, fast,

In cataract over cataract, on her soul.

Then at the last she rose, a reeling shape

That like a shadow sway'd against the wall,

Her slight hand held upon her bosom, and fell

Before the Virgin Mother on her knees. (259),

after which “all was still.” In Morris's poem, it is Launcelot who

... stretch'd my hands towards her and fell down,

How long I lay in swoon I cannot tell:

My head and hands were bleeding from the stone,

When I rose up, also I heard a bell. (11. 393-96)

Significant contrasts remained. Lytton's Guenevere, for example, steadfastly affirms her love. Morris's Guenevere, in her desperation and confusion, denies it, and even accuses Launcelot of malice against Arthur, a painful thought to them both. Lytton's lovers are afforded the saving grace of a farewell kiss, a consolation denied them by Malory and Morris alike.

But Morris's starkly beautiful lyrics also arrested the lovers' grief in frozen frames of vivid prismatic memories. Consider, for example, the following passage from "King Arthur's Tomb":

... she would let me wind

"Her hair around my neck, so that it fell

Upon my red robe, strange in the twilight

With many unnamed colours, till the bell

Of her mouth on my cheek sent a delight

"Though all my ways of being; like the stroke

Wherewith God threw all men upon the face

When he took Enoch, and when Enoch woke

With a changed body in the happy place." (11. 44-49)

At their best, Morris's emblematic colors and the startling obliquity of his associations-comparison of a kiss to a bell and the translation of Enoch- 
became small verbal epiphanies that enabled his readers, if only for a moment, to see something through a glass, brightly.

Morris could also convey more keenly the small whirring blades of anguish: when Guenevere, for example, attacks both Launcelot and herself:

The ladies' names bite verily like steel.

"They bite-bite me, Lord God! - I shall go mad,

Or else die kissing him, he is so pale;

He thinks me mad already, O bad! Bad!

Let me lie down a little while and wail.”...

"Alas, alas! I know not what to do,

If I run fast it is perchance that I

May fall and stun myself, much better so,

Never, never again! Not even when I die." (11. 361-64, 389-92)

Moreover, Morris's early encounter with Lytton's Clytemnestra, The Earl's Return ... and Other Poems reinforced several other poetic predilections that he continued to develop in his later work: a love of legendary tales and balladic rhythms, a fondness for the overtly passionate aspects of such tales, and an interest in psychologically charged, introspective presentations of romantic loss. Both poets blended a romantic view of eroticism with a distaste for censorious social judgments, and their representations of the legend of Launcelot and Guenevere clearly reflected these common beliefs. Morris was a great poet and Bulwer-Lytton at his best a good one, but their shared preoccupations were animated by a common conviction that "love is (or should be) enough."

\section{Gogar Allan Poe}

Quite different antecedents for the evocative dreamlike qualities of The Defence may be found in the poetry of Edgar Allan Poe, as Mackail observed:

The part of [The Defence] which one gathers to represent its spirit and form most intimately to many lovers of poetry. . . consists of the poems of a wholly unbased and fantastic romance, in which any traceable poetical influence is that of Poe rather than of Browning. Their very names-such 
names as "The Blue Closet," or "The Sailing of the Sword," or "Two Red Roses across the Moon"-are taken straight out of dreamland. . . . Never perhaps has poetry come nearer to what some theorists have laid down as its goal, the emotional effect of music, than in some of these remarkable pieces- "The Wind," "Spellbound," "Near Avalon." Even now, to those to whom they have been long familiar, their faint beauty comes back, ever and again, like a fugitive and haunting scent, or the vague trouble of a dream remembered in a dream. ${ }^{47}$

Any remarks Morris may have made about Poe's poetry are no longer extant, but Poe's Poetical Works had appeared in London in $1853,{ }^{48}$ he was one of Rossetti's favorite poets, ${ }^{49}$ and Burne-Jones described his tales enthusiastically in letters from Oxford. ${ }^{50}$ Poe was clearly a greater influence on Rossetti than on Morris, but parallels with several Defence poems are nonetheless apparent.

Arguably no other nineteenth-century poet, not even Coleridge in "The Rime of the Ancient Mariner" or Keats in "Isabella, or the Pot of Basil," was as skillful as Poe in creating an ambience of death-in-life-dream states that are at once sensuous and melancholy, seductive and frightening, amorphously remote and vividly irreal. Such altered states, intense forebodings, and surreal landscapes as are found in "Lenore," "Ulalume," and "The Raven"-tombs and towers, ruined palaces by the sea, and sudden confrontations with the specter of a dead love or presages of one's own death-also appeared in Morris's "The Blue Closet" and "The Tune of Seven Towers," and to a lesser degree in "The Wind," "Spell-Bound," and "Near Avalon."

Both Poe's "Haunted Palace" and "The Tune of Seven Towers," for example, confronted their readers with liminal specters in a ghastly castle. Compare, for example, the following excerpts from Morris's The Blue Closet" and "The Tune of Seven Towers (st. 2):

And ever the great bell overhead,

And the tumbling seas mourn'd for the dead;

For their song ceased, and they were dead. ("The Blue Closet," 11. 77-79)

No one walks there now;

Except in the white moonlight

47. Mackail, Life, 1:133-34.

48. The Poetical Works of Edgar Allan Poe, London: Addy and Co., 1853.

49. Elizabeth Lee, "Rossetti and Poe," Review of the Pre-Raphaelite Society 15.2 (Summer 2007).

50. Memorials, 1:88. 
The white ghosts walk in a row;

If one could see it, an awful sight,-

"Listen!" said fair Yoland of the flowers,

"This is the tune of Seven Towers" ("The Tune of Seven Towers," st. 2)

with the following passages from Poe's "The Haunted Palace":

And travelers now within that valley

Through the red-litten windows see

Vast forms that move fantastically

To a discordant melody;

While, like a ghastly rapid river

Through the pale door

A hideous throng rush out forever,

And laugh—but smile no more.... (st. 6)

and his evocation of a timeless realm of living death in "Dream-Land":

From a wild weird clime that lieth, sublime,

Out of Space-out of Time....

By the lakes that thus outspread

Their lone waters, lone and dead,- (“Dream-Land," sts. 1, 3).

Two of Morris's characteristic emotions are largely absent in Poe's trancestates; heterosexual anxiety and 'chivalric' courage and resistance. Poe's speakers simply assume that death has separated them from otherwise loving partners (Lenore, Eulalie, Ulalume, and Annabel Lee), and his protagonists make few moral choices and seem completely at the mercy of their subconscious impulses. Even the "gallant knight" of Poe's "Eldorado" searches with his last breath, not for forgiveness or redemption, but for the notoriously elusive 'land of gold':

... as his strength

Failed him at length,

He met a pilgrim shadow:

"Shadow," said he,

"Where can it be,

This land of Eldorado?"

"Over the Mountains

Of the Moon, 
Down the Valley of the Shadow,

Ride, boldly ride,"

The shade replied,

"If you seek for Eldorado!" (sts. 3-4)

Still, an awareness of Poe's poetry might have heightened Morris's temperamental fascination with borderline states between 'lower' and 'higher' levels of consciousness. A religious agnostic who yearned for such liminal passages, he wrote them into several of his Earthly Paradise tales-among them "Ogier the Dane"; "The Land East of the Sun and West of the Moon"; and to a somewhat lesser degree "The Hill of Venus." As a poet who experienced such waking dreams and sought secular forms for their expression, he may have found way-markers in Poe's slender volume for his own poetic art.

\section{ONCLUSION}

Many wefts of association made the legends of Launcelot, Guenevere, and the quest for the Holy Grail interesting to the young Morris. Traces of the influences of Tennyson, Browning, Rossetti, Poe, and Bulwer-Lytton may be found in his poems' musicality, historicism, brooding images, incantatory dreamlike states, and sympathetic portrayals of strong, passionate women, and he assimilated the afterimages of these antecedents in The Defence of Guenevere.

Morris originally made plans for a longer Arthurian cycle that largely excluded Arthur in a work which might have been called "The Fellowship of the Round Table," but he was disinclined to retrace ground already claimed by Tennyson, and only six of his Defence's thirty poems made allusion to figures or places in the original Malorian texts. Four of these, admittedly, are among the volume's best-known works. But their more arresting qualities derived from Morris's ability to decant very new wine in old bottles; create broader quasi-historical settings for grittier extensions of intricately plotted medieval legends; and rewrite these legends with a sensibility compatible with his own poetic ideals.

Always an avid reader of histories and chronicles that many others found tedious, Morris drafted poetry that was more consistently and realistically 'medieval' in its setting, and over time shifted his focus from Malory to include a broader range of folkloric and historical sources. The most important of these sources was Jean Froissart's Chronicles of England, France, Spain, and the Adjoining Countries, whose descriptions of the period of the Hun- 
dred Years' War offered a more historically concrete basis for depictions of desperate as well as heroic struggle, estrangement, and unfulfilled love.

As readers will recall from chapter 1, in his Literary Gazette review of March 1858, Richard Garnett made a bold claim for the authenticity of the result:

Tennyson writes of mediaeval things like a modern, and Mr. Morris like a contemporary. Tennyson's "Sir Galahad" is Tennyson himself in an enthusiastic and devotional mood; Mr. Morris' is the actual champion, just as he lived and moved and had his being some twelve hundred years ago. Tennyson is the orator who makes a speech for another; Mr. Morris the reporter who writes down what another man says. ${ }^{51}$

In these attempts to 'write it down', Morris sought to find historically based ideals that had nothing to do with 'success', and to memorialize men and women who confronted near-certain failure. In the process, his search for a humanitarian basis for erotic love led him to imagine the physical and emotional oppression of women deprived of autonomy in a repressive and unjust society. Seen in this light and the larger frame of his temperamental egalitarianism and empathy with admirable lost causes, The Defence was in part at least a kind of spiritual exercise, in which he took stock of his inner resources, prepared to undertake the tasks of personal, artistic, and political "fellowship," and tried to "find what wind will serve to advance an honest mind."

Much later in his life, he suggested to his daughter May that the best way to use a literary source was to "shut the book, and tell it again in your own way." 52 As he composed The Defence of Guenevere, Morris read his chosen predecessors with care; closed their books firmly but respectfully; and set out to find his own ethical and artistic path.

51. Literary Gazette, March 1858, no. 42, 226-27.

52. $C W, 3$ :xxii. 


\section{ENDER POLARITIES IN}

\section{THE DEFENCE}

ater in life in News from Nowhere (1890) William Morris put forth the radical view that sexual and familial arrangements should be voluntary, ${ }^{1}$ but his portraits of confined, alienated, and dependent women in The Defence of Guenevere pose a number of questions by contrast. Did they, for example, simply stylize and project onto these figures some of the more destructive conventions of Victorian patriarchy? Or alternately, did they actually provide a substantive "defense" of female passion and sexuality against the social hierarchies and emotional suffocation they described?

I will argue that his portraits did provide such a defense, for Morris valued highly many traits he attributed to his female protagonists, and used his characterizations of them to defend un-'Victorian' suspension of judgment about female sexual conduct. His early poems had showed insight into the distorting effects of sexual polarities, and their counterparts in The Defence

1. News from Nowhere, ed. Clive Wilmer (Harmondsworth: Penguin, 1998), chap. 9, pp. 90-93; also at the William Morris Archive, http://morrisedition.lib.uiowa.edu/ newsfromnowhere/ch9.html. See also Florence and William Boos, "Victorian Socialist-Feminism and William Morris's News from Nowhere," Nineteenth-Century Contexts 14.1 (1990): 3-32. For ways in which he did share the ideals of fin de siècle feminism, see the interview with Sarah Tooley reproduced from the 19 April 1894 Women's Signal in Tony Pinkney, ed., We Met Morris: Interviews with William Morris, 1885-96. 
represented forms of artistic and sensuous "love" with which he consciously identified himself, and anticipated a world in which such forms of "beauty" might become independent social forces and sources of ethical insight.

Morris's "defenses" of these social forces and ethical insights evolved over time, and operated in The Defence at several levels of which the twenty-four year old author may not have been entirely aware. They presented, for example, a critique of the stultifying effects of gender-segregation in a violent medieval society, and by inference, Victorian England. Against these pressures, they also granted some of the work's heroines-Jehane, Guenevere, and Lady Alice-declamatory passages in which they struggled to articulate codes of integrity and moral behavior derived from their experiences as women.

Language is the bearer of value in poetry, finally, and these monologues have evoked a wide variety of responses from readers past and present. The variety and intensity of these responses suggest that these portrayals still have the power to evoke latent social and emotional tensions. I will consider in what follows two aspects of Morris's sketches of women's situation in The Defence: the extreme polarity of the social and sexual roles that confined them, and the rhetorical resistance to these confining roles which (partially) liberated them.

\section{$\int$ exual polarities}

By general consensus, The Defence of Guenevere contained Morris's best early poetry. Its lyrics and dramatic monologues were intense, startling, and dreamlike, and its medievalism unhindered by pedantry. Critics have concentrated on the ambiguities of the Launcelot-Guenevere-Arthur triangle, but the work's principal motifs are its protagonists' complex emotions and pervasive fears of frustration and defeat. ${ }^{2}$ Ralph Berry has pointed out that twenty

2. Laurence Perrine, "Morris's Guenevere: An Interpretation"; Carole G. Silver, "The Defence of Guenevere': A Further Interpretation"; Audrey Bledsoe, "The Seasons of Camelot”; Florence Boos, "Justice and Vindication in William Morris's The Defence of Guenevere"; Blue Calhoun, The Pastoral Vision of William Morris; Constance W. Hassett, "The Style of Evasion: William Morris's The Defence of Guenevere, and Other Poems"; Amanda Hodgson, "Riding Together: William Morris and Robert Browning"; Elizabeth Helsinger, "Lyric Colour: PreRaphaelite Art and The Defence of Guenevere"; Karen Herbert, "Dissident Language in The Defence of Guenevere"; Debra N. Mancoff, "Problems with the Pattern: William Morris's Arthurian Imagery"; David G. Riede, "Morris, Modernism and Romance"; and David Shaw, "Arthurian Ghosts: The Phantom Art of 'The Defence of Guenevere." For a fuller list, see bibliography. 


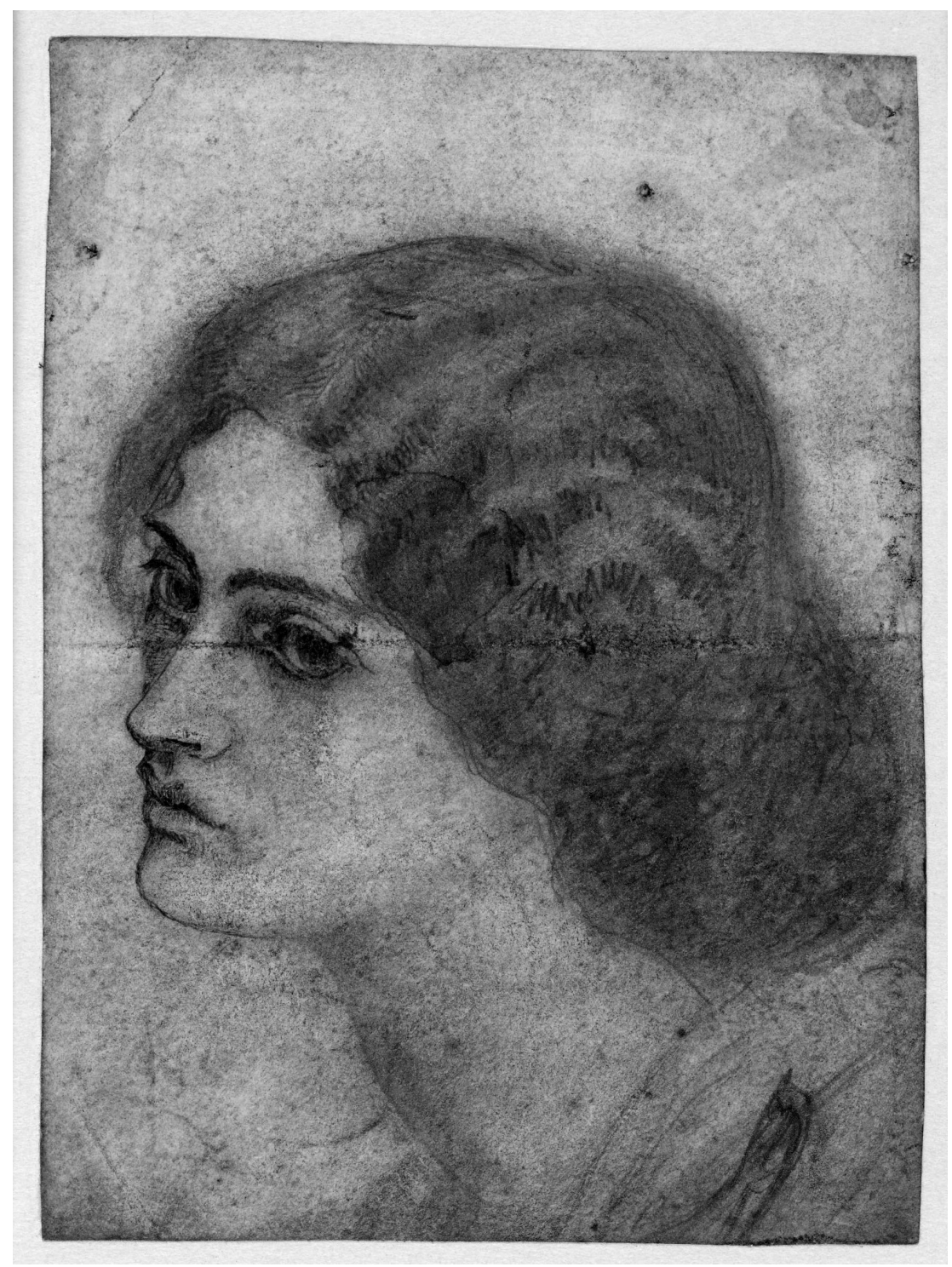

FIGURE 17. Drawing of Jane Burden by William Morris. Courtesy of the British Museum. 
of the volume's thirty poems ended in death or defeat, ${ }^{3}$ and most of the characters in poems with relatively benign outcomes (the title poem, for example) are preoccupied with anxiety and struggle. These pervasive ground-motives of defeat and sexual tension also reinforce each other, for most protagonists "love that well which [they] must leave ere long."

In his Critique of Everyday Life, the mid-twentieth-century Marxist philosopher Henri Lefebvre reflected on the paradoxical attraction of artistic traditions "created in conditions which were very different from our own by groups . . . which established themselves using unbridled and limitless violence":

How could we not grasp the works of the past? They interest us, they fascinate us, and we call upon them desperately to give us a sense and a style. In the name of the vast emptiness which is everyday life, our everyday life, we look towards everything which could point to or perpetuate a plenitude. ... We perceive them as art objects, whereas in fact this art was not something external to the everyday or, as is supposed, high above it and trying in vain to enter it, but a style of life. ${ }^{4}$

Morris anticipated Lefebvre's view of the "vast emptiness" in the present, as well as his belief that the art of the past arose from everyday patterns-the "lesser arts"- which survived in the margins and sanctuaries of a violent feudal and early modern society.

Like Lefebvre, Morris also believed that "the link between the tragic and the everyday is profound; the tragic takes shape within the everyday, comes into being in the everyday, and always returns to the everyday."5 Accordingly most of The Defence's soldiers and small landholders and their wives and lovers were ordinary people driven to passion or violence by disruptions of their everyday lives.

Another of Lefebvre's notions-of "moments," or passionate mental states that create clarity, motivate risk, and thus shape specific forms for human aspiration-may be found in The Defence of Guenevere. The choices made in such "moments" (or their "constellations") resolve ambiguities, but they also "cannot endure" (at least, not for very long), for "this inner contradiction gives [them their] intensity, which reaches crisis point when the inevitability of its own demise becomes fully apparent." ${ }^{6}$

3. Ralph Berry, "A Defense of Guenevere"; see also his "The Symbolism of William Morris"; and Megan Ward, "William Morris's Conditional Moment."

4. Henri Lefebvre, The Critique of Everyday Life, 2:321-22.

5. Ibid., 347 .

6. Ibid., $344-45$. 
One could formulate a fairly good description of The Defence's armed conflicts, imprisonments, and ambiguously imagined love scenes in such terms. A Lefebvrean "moment," for example,

weaves itself into the fabric of the everyday, and transforms it partially and "momentarily," like art, like the figure in a carpet... The moment is passion and the inexorable destruction and self-destruction of that passion. The moment is ... aimed at, desired and chosen as such. [Its "impossibility" is] the tragedy of heartbreak, of alienation, of failure at the heart of fulfillment, of the return to the everyday to start the process all over again.?

Anticipations of such Lefebvrean "moments" dominate the experiences of the protagonists of The Defence of Guenevere when they are forced to make fateful choices in medias res, with little knowledge of the "alienation ... [and] ... failure at the heart of fulfillment" that these might entail. Some of these consequences become clear at the conclusion of specific poems, but others remain deferred or enigmatically indeterminate.

Many of Morris's protagonists in The Defence, for example, struggle against death, defeat, or violation of cherished ideals, painfully aware that all their psychic victories may be illusory, that their failures may destroy those they love, and that love itself may be eroded by distance or degraded by time. As they fall prey to desperation, they also become disoriented, lose their bearings in time and space, and/or succumb to madness or paranoia. No specific agent can be blamed for the injuries and deaths of these characters in poems such as "The Wind" or "The Tune of Seven Towers", and the moral situation of embattled speakers in "The Judgment of God" and "The Eve of Crècy" remains at least open to question.

Steeped in accounts of violent medieval conflicts, more than most other Victorian poets the twenty-four-year-old Morris also went out of his way to document the violence and degradation that flowed from feudal abuses of power, and to celebrate the principled courage of those who struggled to preserve cultural memories against the Lefebvrean tragedy at the heart of the everyday. For The Defence of Guenevere portrayed a Hobbesian war of all against all, tempered by a few ethical imperatives and "moments" of preternatural clarity. Violence was endemic in this "lifeworld," and memory and tradition were elusive and ambiguous. Sir Peter Harpdon's legend is effaced and distorted; the narrator of "Concerning Geffray Teste Noire" has nothing to show for his life but an effigy of two persons he has never met; and the speaker of "The Wind" struggles in vain to recover and understand a traumatic past that now lies beyond his comprehension.

7. Ibid., $346-47$. 
Bleak motifs of this kind also pervade The Defence's haunting refrains, its insistent focus on symbolic visual detail, and (since the past is another country) its translations and reconstructions of medieval English, French, and German lore into nineteenth-century verse. Morris's uses of insistent rhythms and dissonances also created a kind of 'emotion recollected in agitation, or sense of brooding estrangement ${ }^{8}$ heightened by cognate uses of stark, clearly delineated images, strong rhythms derived from ballads and other folk meters, and snatches of refrains or partial refrains ("Beata mea Domina," "Two red roses across the moon," "When the sword went out to sea," "This is the tune of Seven Towers ..."). Another source of tension derived from the degree to which erotic frustrations heightened the intensity of love and strife alike, as confined women waited for men whose 'self-respect' required that they kill or be killed.

Morris sensed that fatalism and resignation were inadequate responses to this predicament, and he had the grace to sympathize not only with "good" heroines such as Jehane and Alice, but complex not-so-"good" protagonists such as Guenevere in "King Arthur's Tomb" and Yoland in "The Tune of Seven Towers." Many of their consorts were similarly constrained and literally alienated, from their wives, their children, and lovers, who dwindled to half-remembered hopes-deferred-“dear as remembered kisses after death, / or sweet as those by hopeless fancy feigned. . . "' Harsh variants of these polarities had already been already present in Morris's contributions to The Oxford and Cambridge Magazine - in "A Dream," for example, in which Ella demanded that her lover Lawrence 'prove' himself in the "cavern of the red pike" which swallowed him up for four hundred years, with semiconjugal visits once each century, before the two estranged lovers were reconciled in death.

Less temporally audacious polarities recurred in the lifeworld of The Defence, in which men and women were preternaturally dissimilar, small

8. Boris Eichenbaum, "The Theory of the Formal Method," in Russian Formalist Criticism: Four Essays, trans. Lee T. Lemon and Marion J. Reis (1965) in Vincent Leitch, ed.:: "[Viktor] Shklovsky likewise repudiated the principle of artistic economy, a principle which had been strongly asserted in aesthetic theory, and opposed it with the device of 'defamiliarization' [ostraneniye in Russian, also translated as 'making strange'] and the notion of 'roughened form. That is, he saw art as increasing the difficulty and span of perception 'because the process of perception is an aesthetic end in itself and must be prolonged'; he saw art as a means of destroying the automatism of perception; the purpose of the image is not to present the approximate meaning of its object to our understanding, but to create a special perception of the object-the creation of its 'vision,' and not the 'recognition' of its meaning" (1070).

9. "Tears, Idle Tears," in The Poetry of Alfred Tennyson, ed. Christopher Ricks (London: Longmans, 1987), ll. 16-17. 
actions moved in fields of exaggerated and unpredictable sexual force, and heroic men and women were separated not only from each other, but also from most forms of tranquil everyday life. Erotic tensions heightened rather than assuaged the pain of their estrangement, and their responses hovered in uneasy balance between protest and affirmation.

Clear evidence for the oppressive nature of this radical partition may be found throughout The Defence. In "The Defence of Guenevere" and "King Arthur's Tomb," for example, Guenevere and Launcelot are almost always separated; a stereotypically manly life of action drives him forth into the world, and rigid social constraints confine her to castle and nunnery. His is the oppression of senseless unavailing labor, hers the humiliation of selfconscious confinement and inaction. The figure of Guenevere provided an iconic focus for Morris's early preoccupations with love triangles and suffering women, and the reader first encounters her as a human being whose every thought and gesture is choked, strained, and constricted as she prepares to die "quite alone and very weak":

... knowing now that they would have her speak,

She threw her wet hair backward from her brow,

Her hand close to her mouth touching her cheek,

As though she had had there a shameful blow,

And feeling it shameful to feel aught but shame

All through her heart, yet felt her cheek burned so,

She must a little touch it; like one lame

She walked away from Gauwaine. ... ${ }^{10}$ (ll. 1-8)

Morris's apparent identification with a "woman taken in adultery" greatly heightened the work's poignancy as well as its complexity, the more so as Guenevere made her case in an oddly disjointed fashion that left in suspension whether she had actually committed the "treasonable" offense of adultery. Morris was less interested in generic "sin" than the special circumstances of a woman married for reasons of state to a cold and neglectful spouse. He was at work on The Defence when the Divorce Law of 1857 permitted men but not women to sue for divorce on grounds of adultery, and in keeping with his ideal of cohabitation based on affection rather than compulsion, he cre-

10. Passages from The Defence of Guenevere are cited from The Defence of Guenevere and Other Poems, ed. Margaret Lourie (New York: Garland Press, 1981), and the William Morris Archive, http://morrisedition.lib.uiowa.edu/defenceguenevere.html. 
ated a pair of characters who vindicated this conviction, and left questions of technical innocence in abeyance.

As Angela Carson pointed out many years ago, ${ }^{11}$ Malory's text offered two conflicting accounts of the lovers' conduct. In "The Knight of the Cart” (book 19 of "The Book of Sir Launcelot and Queen Guinevere"), Malory acquitted Guinevere of the implausible charge of adultery with one of her wounded knights, but described in some detail the lovers' assignation that led to Mellyagaunce's discovery of the bloodstained sheets. But in “The Most Piteous Tale of the Morte Arthur Saunz Guerdon,” Malory seemed to confirm Launcelot's assertion that Guinevere had been "trew unto my lorde Arthur," ${ }^{2}$ and left in ambiguous suspension whether "they were abed other at other manner of disportis, me lyste nat thereof make no mencion, for love that tyme was not as love ys nowadays" (821). His Launcelot, moreover, managed to say with apparent conviction that "my lady, queen Guenyver, ys as trew a lady unto youre person as ys ony lady lyvyng unto her lorde" (837), and asserted that

hit was never in my thought . . . to witholde the quene frome my lorde Arthur, but ... mesemed hit was my parte to save her lyff and put her from that daunger tyll bettir recover might com. $(842)^{13}$

In other respects Morris's interpretation of the tale contrasted quite sharply with its Malorian prototypes. ${ }^{14} \mathrm{He}$ ignored the genuine amiability of Malory's Arthur and his initial heartfelt friendship with Launcelot, for example, as well as the general ambience of the original tale's military caste-system and (to a later reader, perhaps) tedious dynastic intrigues. ${ }^{15}$ Malory's Guine-

11. Angela Carson, "Morris's Guenevere: A Further Note"; Silver, "The Defence of Guenevere:' A Further Interpretation"”; David Staines, "William Morris's Treatment of His Medieval Sources in The Defence of Guenevere."

12. Eugene Vinaver, ed., The Works of Sir Thomas Malory, 848. Page numbers for further quotations from Malory are from this edition.

13. For a fuller discussion of Morris's sources in Malory, see the appendix: "Malory's Guinevere and Morris's Guenevere."

14. As discussed in chapter 3, "The Chapel in Lyoness" appeared in the September Oxford and Cambridge Magazine, and may have been the first completed of the sequence. It is also likely that the second two Malorian poems predate the first ones, and were written during a period in which Rossetti painted his 1857 "The Arming of a Knight from the Christmas Mystery of 'Sir Galahad'" on the back of a chair designed by Morris for the apartment he shared with Burne-Jones before his marriage (H. C. Marillier, Dante Gabriel Rossetti: An Illustrated Memorial of His Life and Art [London: Bell, 1899], 89). The other chair-back contained Rossetti's drawing of "Guendolen in the Witch-Tower," also from 1857. A discussion of the treatment of the figure of Sir Galahad in Pre-Raphaelite painting appears in Jan Marsh, "Knight and Angels: The Treatment of 'Sir Galahad' in the Work of Gabriel Rossetti, Elizabeth Siddal and William Morris."

15. In Malory, Gauwaine's anger is partially provoked by Launcelot's killing of his two 
vere had also been a politically astute and self-respecting aristocrat in her own right, not Morris's baffled and intimidated woman "born for love alone" and prostrate with shame before "such great lords." Finally, Morris's portrayal of Guenevere's and Launcelot's last conversation, riven by cross-purposes and accusations, differs sharply from the Malorian couple's noble sentiments expressed in their last encounter.

It has been suggested that The Defence's more 'religious' and 'sublimated' Arthurian poems_-"Sir Galahad: A Christmas Mystery" and "The Chapel in Lyoness"-lacked the originality and erotic complexity of the title poem and "King Arthur's Tomb." But Galahad's epiphany is very brief, and Ozana's final dream-vision is not of Christ, but of tresses of golden hair "[ $t$ ]hinly outspread in the clear air / Against the jasper sea." Elsewhere in The Defence earthly gardens are described in awed detail, but their empyreal counterparts in "The Chapel in Lyoness" remain elusive phantasms. The heavenly maidens of "Sir Galahad" are also rather etiolated symbols of sublimation, and Galahad's loneliness and Ozana's wistful confusion are more memorable than their visionary rewards. Unlike Tennyson's Galahad, whom Morris had described as "a mild youth," his own Galahad was a "knight of infinite resignation" and lonely defender of an evanescent ideal. ${ }^{16}$

Morris's lingering sympathies for the intermingling of erotic and 'spiritual' sentiment and his assimilation of ascetic ideals to solitary effort and postponed love are thus apparent throughout the Malorian poems of The Defence. In his later works the religiously tinged erotic mysticism of his Arthurian poems yielded to secular sources of sublimation, a fortuitous shift that also offered him greater freedom in departing from his source materials. ${ }^{17}$

By contrast with the Malorian poems' spiritual exercises, the secular adventures of Froissart's Chronicles may therefore have offered Morris a welcome chance to immerse himself in concrete historical narrative. Once again, however, he reworked Froissart's sparse chronicles to explore the emotions of men killed or imprisoned by their enemies and women immured in

brothers Gareth and Gaheris; as in Icelandic sagas, deaths of medieval kinspeople require reparation. Malory narrates a tragedy of inevitable conflict between honorable persons who mostly respect one another, and who generally subordinate brief moments of passion to considerations of friendship, political honor, or loyalty to kin.

16. For the "knight of infinite resignation," see Soren Kirkegaard, Fear and Trembling in Kirkegaard's Writings, vol. 6, ed. Howard V. Wong and Edna H. Wong. Princeton: Princeton University Press, 1983, 46.

17. Compare Dennis Balch's remark in "Guenevere's Fidelity to Arthur in 'The Defence of Guenevere' and 'King Arthur's Tomb" that "Morris [gradually] realized that the Arthurian legends embodied a system of values contrary to the values he himself was developing which would depend on the central importance of the individual sensual experience rather than a denial of man's animal nature" (70). 
stereotypical confinement, ${ }^{18}$ as in "Sir Peter Harpdon's End," the longest of the Froissartian Defence poems.

In 1857 Morris saw a London performance of Richard II, his favorite Shakespearean history play (a fact of some interest in itself), and he set "Sir Peter" in the late 1370s, shortly after the coronation of Richard II and at a juncture in the Hundred Years' War in which the tide had turned against the English. ${ }^{19}$ Several of the names Morris used in the poem-Harpdon, Clisson, John Chandos, and Curzon-also had rough Froissartian originals, though the incident in which Sir Peter is killed did not appear. ${ }^{20}$

At the beginning of Morris's narrative, Sir Peter Harpdon is aware that he is trapped and will in all likelihood be killed, and grieves that he cannot explain anything of this to his beloved Lady Alice. ${ }^{21}$ Like other Morris characters in extremis, he imagines a gently pastoral scene, here one in which he pleads for her forgiveness:

O lady, have I sinn'd, your knight?

That still you ever let me walk alone

In the rose garden.... (11. 93-95)

18. Chronicles of England, France, Spain and the Adjoining Countries .... As discussed in chapter 1, Froissart's often depressing, sordid account assumes the values of a war undertaken by an aristocratic and martial caste.

19. In a rejected fragment, the siege of Peter's castle is dated 10 November, and Silver notes that the reference to the candidacy for the papacy of Clement, who became pope in 1378, dates the poem's action as occurring in November 1377 (Romance, 36-37).

20. A John Harpedon appears in Froissart as a French knight in the English service (vol. 1, chap. 265), who in 1369 defends himself against siege, but in this case is rescued by Sir John Chandos. Also, the name of Peter's right-hand man John Curzon is similar to that of an English knight mentioned in Froissart, vol. 1, chap. 298 ("Sir Johan Cursone"). Clisson, personally sympathetic to Peter in Morris's poem, was a Breton knight and brother-in-arms of Bertram de Guesclin, the Constable of France, and one of the strongest French knights of the time, winning castles from the English in the Poitevin region (Lourie, Defence, 203). See also John M. Patrick's "Morris and Froissart Again: 'Sir Peter Harpdon's End," Notes and Queries 6 (1959): $331-33$.

21. In a rejected opening fragment, Peter's right-hand man Curzon is developed into a rougher analogue to Sir Peter who mourns separation from his sister and fears she may be celebrating a holiday the day he is murdered. The women are carefully exonerated from overt blame, but the rigidity of their roles makes them inadvertently callous to the needs of men in distress ( $C W, 1: \mathrm{xxvi}-\mathrm{xxxi})$. In the rejected opening Peter describes his mental state under siege:

$$
- \text { I feel }
$$

As if I were shut up in [a] close room

Steaming and stifling with no hope to reach

The free air outside-O if I had lived

To think of all the many happy days

I should have had, the pleasant quiet things,

Counted a little then, but each one now

Like lost salvation. ... 
His consolation is an imagined intense and all-forgiving kiss, after which he awakens to the reality of imminent defeat.

Alice is not estranged from him, as Peter fears, and has done her best to send reinforcements to his aid. These cannot arrive in time, however, and the loving couple is parted forever, not by social roles but by the fortunes of war. Like Launcelot, Sir Peter has struggled in vain against oppressive odds, but he "like[d] the straining game of striving well to hold up things that fall ..." (l. 219), and Alice too finds consolation in an ideal garden where

... it all sounds dim

And faint, and I shall soon forget most things; ...

Lying so, one kiss,

And I should be in Avalon asleep,

Among the poppies and the yellow flowers; ... (11. 530-31, 536-38)

Bitterly aware of her inability to revenge herself upon Peter's murderer Lambert, she articulately defines herself as a compassionate woman, in a world controlled by warring men:

And then-alas! alas! when all is said, What could I do but let you go again,

Being pitiful woman? I get no revenge, Whatever happens; and I get no comfort, I am but weak, and cannot move my feet,

But as men bid me. (11. 693-98)

Her overwrought anxieties erupt eerily in a seductive "prayer" addressed to Christ, conceived as the literal incarnation of an effigy in her local church:

Let us go, You and I, a long way off,

To the little damp, dark, Poitevin church;

While you sit on the coffin in the dark...

Until you love me well enough to speak,

And give me comfort; yea, till o'er your chin,

And cloven red beard the great tears roll down

In pity for my misery, and I die, ... . (11. 668-70, 676-79)

Bitterness overcomes her at the thought that Peter's bravery may be unheralded while the world celebrates the prouesse of Launcelot:

Yea, some men sing [the feats of Launcelot].... 
They ought to sing of him who was as wight

As Launcelot or Wade, ${ }^{22}$ and yet avail'd

Nothing . . yea, perhaps they will

When many years are past, make songs of us;

God help me, though, truly I never thought

That I should make a story in this way,

A story that his eyes can never see. (11. 711-13, 715-19)

Her words are prophetic, of course, since in writing "Sir Peter Harpdon's End" Morris has fulfilled her hopes in an instance of fellowship across (imagined) time; and in closing the poet seeks his meed of acknowledgment in the guise of an anonymous medieval maker:

Omnes homines benedicite!

This last fitte may ye see,

All men pray for me,

Who made this history

Cunning and fairly. (11. 744-48) $)^{23}$

"Sir Peter Harpdon's End" is one of The Defence's best dramatic poems, and as an integrated narrative noticeably better than its Arthurian counterparts. Its vigorous characters are Morris's own, and it offers a virtual paradigm of many of his contemporary preoccupations. The twenty-five-year-old Peter is devoted to his beloved and willing to accept defeat in loyal service to an ostensibly worthy cause ("So one becomes great"), and his bereft consort is willing to call down the heavens to witness her grief and respect for a worthy lover she will never see again.

At the beginning of "Rapunzel," a dreamy, hesitant prince named Sebald rides out "to look for love," and sees

22. Wade was a folk hero mentioned in Chaucer's "Merchant's Tale" ("And eeke thise olde wydwes [God it woot], They konne so muchel craft on Wades boot," E1423-24) and Malory, "for wert thou as wight as ever was Wade, or Sir Launcelot, Sir Tristram" (bk. 7, chap. 9 [Vinaver's translation omits the name of Wade]). Several Wades appear in Scandinavian and British history; for example, a Saxon Wade led a revolt in 798 in which King Aethelred was murdered, after which he and his co-conspirators died in battle near Whalley in Lancashire.

23. Margaret Lourie points out that the last stanza of an English metrical romance was often a prayer (though Morris adds the poet's request that the prayer be on his own behalf) (Defence, 211).

24. Lourie identifies the source as Household Stories Collected by the Brothers Grimm, illus. E. H. Wehnert, 2 vols. (London: Addey, 1853). She remarks, "If in the Arthurian and Froissartian poems Morris preserves mood and detail of his source but changes plot, he reverses his tactic with Grimm and softens the familiar story into one of mist and dream" (Lourie, Defence, 212). 
a tower which he considers the appropriate dwelling for a virginal and beautiful woman. But

... on all sides I saw the proofs

Of a great loneliness that sicken'd me;

Making me feel a doubt that was not fear,

Whether my whole life long had been a dream... (11. 89-92)

In this dream-state he experiences a moment of self-knowledge and awakening:

Not born as yet, but going to be born,

No naked baby as I was at first,

But an armed knight, whom fire, hate and scorn

Could turn from nothing: my heart almost burst. . . . (11. 95-98)

The prince's anticipatory images of Guendolen (for so he names the woman he intends to save) evoke "her face quite pale against her hair," her grotesque victimization by "foul things ... / In the . . likeness of Devil's bats ...," and her "half smile on the lips, though lines of care / Had sunk the cheeks, and made the great eyes hollow" (1l. 266-67). Before he finds her, however, he must spend an obligatory period of lonely trial and selfreproach that parallels Launcelot's painful fears en route to Glastonbury and Galahad's dark night of the soul on the way to Lyoness.

Rapunzel, for her part, responds to her incarceration with lamentation, fear, prayer, and desire for "a kiss, / Dear God, dwelling up in heaven!," and is granted relief in a peaceful trance in which she

... [b] ehold[s] the countenance

Of Michael, and can feel no more

The bitter east wind biting sore

My naked feet; can see no more

The crayfish on the leaden floor,

That mock with feeler and grim claw. (11. 194-99)

These repellent visions and tactile invasions have appeared on the nights when the witches plaited her hair, but in good Victorian fashion she did not attempt to escape, but awaited the arrival of an outsider who will liberate her in "this very place." When at length the Prince duly arrives, he confides to her the disturbing nature of his own dreams and fears of death and treachery in 
combat, and she answers with the healing suggestion that he leave his fears for love-"Yea, love; but shall we not depart from hence? / The white moon groweth golden fast ..." (11. 249-50).

"Rapunzel" can of course be read as a familiar Victorian initiation into conventional social and sexual roles, but its ending has also been interpreted as a romantic rejection of military ambition and embrace of a better world of love and imagination. ${ }^{25}$ Much turns on the poem's interpretation of the Prince's ambiguous "sword":

Now let us go, love, down the winding stair,

With fingers intertwined: ay, feel my sword! ....

Guendolen now speaks no word,

Hands fold round about the sword.

Now no more of Guendolen. (11. 259-60, 299-300)

The matter is internally resolved when the prince contrasts the "wars and business" he has left with his lonely quest for love, and Guendolen promises him that "[y]our hands need never grip the hammer'd sword again, / But all my golden hair shall ever round you flow" (11. 306-7).

At the tale's end, the Prince's largely symbolic struggles have been poetically brief, and he and his consort take their places in an ordered but sensuous world:

I am so glad, for every day

He kisses me much the same way

As in the tower; under the sway

Of all my golden hair. (11. 314-17)

Since their subsequent lives together are presumably lived in peace, the tale offers a fairy tale alternative to the Defence's harsh world, but no solace for the Peter Harpdons and Lady Alices trapped within it.

Similar schematizations of gender roles recur in varying forms and patterns in almost every poem in The Defence. In "The Gilliflower of Gold," for example, the male lover fiercely defends his beloved in a tournament. Gillyflowers ${ }^{26}$ were a common presence in poetry as well as heraldry, and they

25. Interpretations of this poem include Robert Stallman, "Rapunzel' Unravelled”; Dianne F. Sadoff, "Imaginative Transformation in William Morris's 'Rapunzel”'; and Carole G. Silver, The Romance of William Morris, 40-42.

26. The name "gillyflower" refers to any of a number of flowering plants, including the carnation. See Shelley O'Reilly, "Identifying William Morris' 'The Gilliflower of Gold."” 
recall here the yellow lilies of Morris's early poem "The Three Flowers" and the "House of Lilies" of "The Hollow Land," as well as the ballad "Clerk Saunders" ("Down at the foot of our good Lord's knee / Neel set about wi' gillyflowers"), the subject of an 1857 watercolor by Elizabeth Siddal.

Like Launcelot in "The Defence of Guenevere" and the protagonists of Browning's "After" and "Count Gismond," the hero of "The Gilliflower of Gold" battles an evil and cruel opponent, here a certain Sieur Guillaume. The prince in "Rapunzel” was moved from trancelike uncertainty by Rapunzel's beauty, but the speaker of "Gilliflower" is galvanized by fear of his love's imminent death:

I almost saw your quiet head

Bow'd o'er the gilliflower bed,

The yellow flowers stain'd with red

Hah! Hah! la belle jaune giroflée. (11. 56-60)

In "The Eve of Crècy," the reader encounters the reveries of a doomed French combatant named Lambert on the eve of the first decisive French defeat in the Hundred Years' War. ${ }^{27}$ Marguerite, the woman of his dreams, is beautiful and long-haired, but physically remote and beyond his economic reach, since he is a mere "banneret" or lower-ranking knight ${ }^{28}$ ("If I were rich I would kiss her feet, / I would kiss the place where the gold hems meet," 11. 9-10).

Of Margaret sitting glorious there,

In glory of gold and glory of hair,

And glory of glorious face most fair;-

Ah! qu'elle est belle La Marguerite. (11. 29-32)

His longing for "Daisy" is not disinterested, though, for it is commingled with a desire for "heaps of food and firewood," and he makes the mistake of waiving the obligatory night of self-examination before combat, a fatal sign in the chivalric world of The Defence.

Other poems in the troubled-but-gallant-knight pattern include "Two Red Roses across the Moon," "Father John's War-song," "A Good Knight in Prison," and "The Little Tower." In the latter, a nobleman rides away from the

27. The English killed rather than captured their enemies on this occasion, so the implication is that the speaker will die the next day.

28. A "knight banneret," or "commoner of rank," led a small number of troops under his own square-shaped banner. 
king's council-table to defend his remote castle from invasion and his lady from death, and he bravely faces siege and other obstacles he knows he may not overcome:

Though our arms are wet with the slanting rain.

This is joy to ride to my love again: ...

What matter: up and down hill after hill;

Dead grey night for five hours still. (11. 6-7, 21-22)

(Some of Morris's rhymes in this poem are themselves small acts of poetic courage- "There she stands, and her yellow hair slantingly / Drifts the same way that the rain goes by" [11. 29-30]).

His lady_fair and golden-haired, once again-may die at the stake. And her beauty, like that of Rapunzel/Guendolen, becomes an emblem of his people's freedom and independence ("My lady is right fair, see ye! Pray God to keep you frank and free" [11. 51-52]). His successful rescue of her, and their chance to grow old together, would be the triumph of his life:

Many a year when we are dead,

And over it our green and red,

Barred with the Lady's golden head;

From mere old age when we are dead. (11. 55-58)

Compare this passage with Morris's passionate declaration in his earlier review of Browning's Men and Women in The Oxford and Cambridge Magazine:

For ["Childe Roland"] and all the others seem but a supplement to the lovepoems, even as it is in all art, in all life; love, I mean, of some sort; and that life or art where this is not the case is but a wretched mistake after all. ${ }^{29}$

A different pattern of estrangement mediated by traces of popular art and song appears in "The Wind," an eerily indeterminate, highly symbolic and dreamlike poem whose haunting images and rhythms echoed its protagonist's descent into madness and death. Stricken by fear and unable to move, its unnamed protagonist-recently returned, perhaps, from the Hundred Years' War-"sit[s] and think[s] of love that is over and past, / O! so long ago...." Afflicted by what would in our century be called posttraumatic stress disorder, he can barely distinguish the recent and distant past, and dreads the dawn that once had cheered him:

29. Oxford and Cambridge Magazine, March 1856, 169. 
If I move my chair, it will scream, and the orange [on a tapestry] will roll out far,

And the faint yellow juice ooze out like blood from a wizard's jar;

And the dogs will howl for those who went last month to the war. ...

I shriek'd and leapt from my chair, and the orange roll'd out far,

The faint yellow juice oozed out like blood from a wizard's jar;

And then in march'd the ghosts of those that had gone to the war. . . (ll.

$16-18,79-81)$

In this passage-which bears out Elizabeth Helsinger's observation that its "colors and image evidently lock up something immensely disturbing"30 - the speaker is apparently suspended in a kind of timeless hell in which he suffers inexplicably from "worn old brains," though the events in his narrative occurred when soldiers "left last month for the war." The woven orange, once a benign emblem of love, has come to represent an irrepressible violence. Except for his brief mention of the "arms I was used to paint," the speaker's original occupation and standing in life remain unclear, and the refrain of the poem's laments is lyrically tormented:

Wind, wind! thou art sad, art thou kind?

Wind, wind, unhappy! thou art blind,

Yet still thou wanderest the lily-seed to find.

As leveler and destroyer, "the wind" grieves the destruction it creates, and courses restlessly over the earth in search of a dormant lily-seed, emblem of deferred rebirth.

Modeled on medieval carols and lost chords of Shelleyan sublimity, the source and import of the refrain remains unclear. Is it the voice of a chorus? An external narrator? The speaker's tortured consciousness? When Morris republished The Defence of Guenevere at the Kelmscott Press in the last years of his life, he took care to reprint all the refrains of "The Wind" in a rutilant 'bleeding' red, as if to suggest that they were insistent, overpowering the narrative elements of the text.

30. Helsinger expands: "The red of the blood, drained from the yellow flowers in the beginning of the dream, now reappears to remind him of the gashed orange on folds of green.... Or rather, the orange with its yellow juice was perhaps all along ... concealing and revealing the remembered blood momentarily covered under the deceptive innocence of the yellow flowers. . . Morris imitates the mind's action through the succession of color images with surprising economy and impact" (Poetry and the Pre-Raphaelite Arts, 72). Carole Silver has identified a possible visual source for the orange in J. E. Millais's "Lorenzo and Isabella," in which the lovers share a blood orange that images the violence to come. 
The traumatic moment of the anonymous protagonist's life has been the strange and macabre death of his love Margaret:

I held to her long bare arms, but she shudder'd away from me

While the flush went out of her face as her head fell back on a tree,

And a spasm caught her mouth, fearful for me to see. (1l. 40-42)

Who or what killed her remains an enigma, but as she dies, "[w]eeping she totter'd forward, so glad that I should prevail," a pointed echo from the murder scene in "Porphyria's Lover." In the speaker's selective memory, in response to his kiss "she [had] kiss'd me on the brow," and as she lay dying he had "spread her arms out wide" and inexplicably walked away. All he records is that as he returned to cover her body with daffodils, he recoiled from the "blood [which] lay in the many folds of the loose ungirded vest ...":

My dry hands shook and shook as the green gown show'd again,

Clear'd from the yellow flowers, and I grew hollow with pain .... (11. 70-71)

In his altered state, the harmless representation of an orange on the nearby tapestry also seems to him to darken and bleed, and he is visited by ghosts, not of Margaret but "of those that had gone to the war."

Who or what murdered Margaret? Was she an innocent casualty in one of the skirmishes of a war fomented by "Olaf, king and saint," the device emblazoned on his comrades' coats of mail? ${ }^{31}$ Was it a mark of the speaker's despair or disorientation that he could not or would not rejoin his fellows in this war? Did he belatedly abhor the war's destruction, and his complicity in it? Was he haunted because he too was guilty-of Margaret's death, or violent war acts, or both-or was he simply distraught by the loss of everyone he had loved? The only answer to these questions was blowin' in the wind that "wander[ed] the lily-seed to find."

It is not greatly surprising that the indeterminacy and disorientation of "The Wind" alienated its first readers in ways that differed markedly from the meliorative "balance of sympathy and judgment" evoked by most of Browning's monologists. And the dissolution of the poem's agitated calm left the reader with little more than its dreamlike angst and the preternaturally vivid intensity of its incantatory refrain.

In “Concerning Geffray Teste Noire," the poem's lonely and distracted elderly speaker, John of Castel Neuf, has waged war for years against Geffray

31. Morris would have encountered King Olaf in Benjamin Thorpe's Northern Mythology (1851), recounted from the "Saga of Olaf Heraldson" in the Heimskringla, and in vol. 1 of Samuel Laing's Heimskringla, or Chronicle of the Kings of Norway (London, 1844). 
Teste Noire, a local tyrant briefly mentioned in Froissart's Chronicles. ${ }^{32} \mathrm{He}$ has also carried with him boyhood memories of women burned to death in a church and his discovery as an adult of the remains of a man and woman killed in flight. Isolated from any personal experience of love, he had fantasized a love scene between the two: "I saw you kissing once, like a curved sword / That bites with all its edge" (11. 173-74). He had later arranged for the remains' joint burial under an effigy carved by "Jacques Picard," the Defence's sole reference to a (fictive) artist by name, ${ }^{33}$ and tried in vain to bring these events to the attention of Jean Froissart. But Picard is "dead now-I am old," and Froissart's Chronicles are silent, as soon he will be in his turn. Aspects of the narrative suggest "The Story of the Unknown Church," but unlike the monk Walter, "John of Newcastle" is denied the satisfaction of crafting his own memorial to the dead.

John and those he pitied represented one of several fates in the roster of The Defence's narrators. Good men are seldom killed 'onstage' in combat, but many of them suffer attrition, weariness, imprisonment, and sudden death thereafter, when they are cruelly murdered, beheaded, or run through treacherously from behind. Others are incarcerated-in the aptly named "In Prison," for example, as well as "Spell-Bound," "Riding Together," and "A Good Man in Prison." Most of Morris's good women tensely await their return in confined enclosures, and several Defence poems reverberate with the anguished frustrations of those who wait.

Yoland, however, in "The Tune of Seven Towers" (a title that alluded to a prison in Constantinople in which Arabs imprisoned their European invaders), is not one of Morris's long-suffering souls, but a sinister égérie after the fashion of Keats's "La Belle Dame Sans Merci" or the enchantress of Morris's "The Blue Closet." Like Ella of "A Dream," she demands that her admirer Oliver harrow a ghostly netherworld for

My coif and my kirtle, with pearls arow ...

If you will go for me now,

I will kiss your mouth at last;

(She sayeth inwardly)

(The graves stand grey in a row.)

32. According to Froissart's Chronicles, vol. 1, chap. 460, Geffray Teste Noire "was a cruell man, and had pytie of no man." A Johan of Newecastell also appears in the Chronicles, vol. 2, chap. 142.

33. Two French engravers named Jacques Picard I and II flourished during the periods 1608-28 and 1658-68. Morris may have grafted their name onto his fictive fourteenth-century sculptor. 
Oliver, hold me fast!

"Therefore," said fair Yoland of the flowers,

"This is the tune of Seven Towers." (1l. 37-44)

The poem's varying line lengths and syncopated rhythms are subtly discordant, creating an eerie evocation of love and incarceration, and the expansion and contraction of lines from dactylic to trochaic meter prompted Helsinger to argue that its "visual patterning - the rows that glimmer and glitter in every stanza ... is realized as aural and graphic pattern: the poem's 'tune, heard or felt and seen on the page." 34

Like "The Tune of Seven Towers," "The Blue Closet" was a poetic response to the death-in-life ambience of one of Rossetti's 1857 watercolors. Alice and Louise are immured in the "Blue Closet," but allowed to sing once a year as a death-knell sounds ominously overhead, and the narrative voice intrudes its insistent rhythms:

Lady Alice, Lady Louise,

Between the wash of the tumbling seas

We are ready to sing, if so ye please;

So lay your long hands on the keys;

Sing: "Laudate pueri." (ll. 1-5)

Like the Lady of Shalott's artistry at her loom, the sisters' singing in the confinement of their "closet" is an emblem of the awareness of death and loss, and the tolling of the bell is for Louise's long-lost beloved Arthur, whose return she has awaited since time immemorial:

How long ago was it, how long ago,

He came to this tower with hands full of snow?

"Kneel down, O love Louise, kneel down!" he said,

And sprinkled the dusty snow over my head. (1l. 37-40)

Arthur now lies full fathom five, and Louise accepts the news with a prayer for reunion:

Dear Lord, that loves me, I wait to receive

Either body or spirit this wild Christmas-eve.

34. Helsinger, Poetry and the Pre-Raphaelite Arts, 7. 
Through the floor shot up a lily red,

With a patch of earth from the land of the dead,

For he was strong in the land of the dead. (11. 58-62)

Both "body and spirit" have supernaturally returned, and the ghostly Arthur invites Louise and Alice to join him in a triangulated afterlife. There is no suggestion that the loyal Alice is reluctant to accompany her sister and her sister's lover unto death, but the familiar dichotomy persists: Arthur has gone forth to meet his death, and Louise and Alice have sadly awaited theirs.

"Golden Wings" - the title is one of several heraldic allusions in The Defence ${ }^{35}$-is a poignant ballad that gains intensity from its spare plot and horrific conclusion. Set in a fortified town, the poem's castle is initially populated for the most part by women, for a vanguard of men are away at war. ${ }^{36}$ The initial descriptions evoke ease and pleasure:

Deep green water fill'd the moat,

Each side had a red-brick lip,

Green and mossy with the drip

Of dew and rain; there was a boat

Of carven wood, with hangings green

About the stern; it was great bliss

For lovers to sit there and kiss

In the hot summer noons, not seen. (11. 12-19)

In this outwardly calm but tense situation, Jehane grieves because her lover has failed to return, and as time passes is seized by a sense of foreboding that he is dead (1l. 59-60). After an agonized night vigil, she resolves to "join" him, and resolutely impales herself on a sword:

... pray God it may come to pass

"I meet him; if ten years go by

Before I meet him; if, indeed

35. Others include "Red Roses Across the Moon," "The Gilliflower of Gold," and "The Little Tower."

36. The motif of a "ladies' castle" appears several times in medieval romance; Lourie notes the presence of a "Castle of Maidens" in Malory and a "Maidenland" in Chrétien de Troyes's Sir Perceval of Galles (Lourie, Defence of Guenevere, 240). In an early version of Morris's “The Wanderers," the poem's adventurers visit a "ladies land." 
Meanwhile both soul and body bleed,

Yet there is end of misery,

"And I have hope." (11. 190-95) $)^{37}$

As often in The Defence Jehane's 'prayer' reflects intense desire rather than religious faith. Her foreboding has been correct, for her lover was one of the first to die in a rout that overtakes the ill-defended castle. After the town is sacked and its inhabitants put to fire and sword,

[t]he draggled swans most eagerly eat

The green weeds trailing in the moat;

Inside the rotting leaky boat

You see a slain man's stiffen'd feet. (1l. 235-38)

It is easy in retrospect to see why reviewers of "Golden Wings" were shocked to encounter an oblique account of a common event in the Crusades and the Hundred Years' War-the savage destruction of a fortified town and inhabitants-presented in the language and imagery of chivalry.

Less brutal aspects of the Victorians' beloved 'middle ages' - the trust its inhabitants put in 'magical' powers, for example-figured in "Spell-Bound," "In Prison," "Riding Together," and "A Good Knight in Prison." In "SpellBound," for instance, set in a quasi-medieval world of charms and myths, a magically imprisoned protagonist says to himself what he would dearly like to say to his love:

... I could not come;

This land was my wide prison, dear...

There is a wizard whom I fear ...

He bound me round with silken chains

I could not break; he set me here

Above the golden-waving plains,

Where never reaper cometh near. (1l. 69-76)

In his misery he also imagines her as similarly enchanted, with

pale face thin and wan with care...

The white dust lying on your hair" (11. 65-66, 68).

37. Echoes of "The Blessed Damozel" abound, as she continues, "He could not come, / But I can go to him and show / These new things I have got to know, / And make him speak, who has been dumb." 
How many hours did [you] wait

For me, I wonder?” (11. 18-19)

His only consolations are fleeting dreams of an alternative realm for yearning souls,

... thy lips

Draw near and nearer to mine own;

But when the vision from me slips

In colourless dawn I lie and moan,

And wander forth with fever'd blood...

$O$ ! dearest, scarcely seen by me-

But when that wild time had gone by,

And in these arms I folded thee,

Who ever thought those days could die? $(11.45-50,53-56)^{38}$

In "Summer Dawn," an aubade in irregular quasi-sonnet form which, as discussed in chapter 3, was originally published in the Oxford and Cambridge Magazine, ${ }^{39}$ Morris's speaker had expressed cognate hopes for an elusive poetic union beyond the realms of sense:

Pray but one prayer for me twixt thy closed lips,

Think but one thought of me up in the stars. (11. 1-2)

Speak but one word to me over the corn,

Over the tender, bow'd locks of the corn. (11. 13-14)

"Corn" had also been a mythic image of fertility in "Father John's War-song" and other Defence folkloric and fairy-tale poems.

In "Praise of My Lady" Morris also varied traditional medieval forms with latinate refrains to express the elusive psychological bonds between two lovers: $:^{40}$

38. Verbal echoes of "In Memoriam" abound: "He is not dead, but gone away" (1. 17); "O dearest, scarcely seen by me" (1. 53); the metaphor of the weeping bride whose lover does not return; the narrator who "wander[s] forth with fever'd blood" (1. 49). Also, as Margaret Lourie observes, the deserted lover resembles Mariana (Defence of Guenevere, 233).

39. Oxford and Cambridge Magazine, October 1856, 644.

40. Lourie provides an example of such a carol followed by a two-line "burden."

Mary is a lady bryght;

Sche haght a Sone of meche myght; 
So beautiful and kind [her eyes] are,

But most times looking out afar,

Waiting for something, not for me.

Beata mea Domina! (11. 29-32)

Sadly, the speaker may find it easier to address other male witnesses than the "beata domina" herself:

All men that see her any time,

I charge you straightly in this rhyme,

What, and wherever you may be,

Beata mea Domina!-

To kneel before her; as for me,

I choke and grow quite faint to see

My lady moving graciously.

Beata mea Domina! (11. 81-88) ${ }^{41}$

Sexual roles have been more or less rigidly polarized in most of the poems considered here, but their complexities and evocative contrasts have evolved away from early portrayals of brave men who rescued fair, frightened women. The elegant madrigal of disparate sexual roles is nuanced by images of loneliness, frustration, forced separations, and profound regret.

On the surface at least, most of the men in The Defence are brave and most of the women are intense and anxious. But there are signal exceptionsamong the latter, Jehane, for example, in "The Haystack in the Floods," who has standard-issue "slender fingers" and "weak hands" but refuses to yield to the tyrant Godmar at the cost of death. Nor are all the women in The Defence as labile as Guenevere or as heedless as Yoland-Lady Alice, for example, is loving as well as steadfast, and Rapunzel/Guendolen is devoted, goodnatured, and grateful for her rescue.

Ouer al this word che is hyght

Bona natalicia.

A, a, a, a,

$\mathrm{Nu}[\mathrm{n}] \mathrm{c}$ gaudet Maria. (Greene, no. 188)

Morris likewise links the final line of his stanza to the burden. The burden itself may have been synthesized from medieval hymns with Latin refrains like "Beata Mater" and "Ave Domina Angelorum" (Lourie, Defense of Guenevere, 254).

41. Compare the similar medievalism of Christina Rossetti's "Monna Innominata": "I charge you at the Judgment make it plain / My love of you was life and not a breath" (sonnet 11). 
But Mary Wollstonecraft was right that women desire "not power over men but over themselves," ${ }^{42}$ and the majority of women in Morris's Defence were powerless in a world that was as 'Victorian' as it was 'medieval.' Sexism is desire for domination often disguised as puritanical rage, and Morris's compassionate portraits of suffering and isolated men and women were a cry of protest from the Victorian unconscious. His empathy with the frustrations of these women corresponded to some aspects of his own desires to liberate and redirect his energies, and his underscoring of the pain of senseless male struggle and senseless female repression expressed a partly unconscious critique of the "ideal" sexual patterns of the society in which he lived.

Morris's early poetry placed high value on the qualities of his male protagonists-courage, fidelity, persistence-but valued equally 'feminine' qualities with which he identified himself: intensity, longing, and sensuous response to physical beauty. As mentioned, he reportedly remarked in later life: "As for me ... I have a love of beauty naturally,"33 and the artistry of his portrayals of intense aesthetic experience is one of the most attractive aspects of his work. Like the strands of Morris's designs, then, the qualities of courage and the love of beauty formed complementary patterns that should have been naturally interwoven, but which social constraints had unraveled. Morris's women represented artistic and emotional forces within every human being which s/he cannot repress without self-destruction; and these forces inspired not only the stereotypical virtues of Morris's male characters, but a deeper acceptance of nature and reverence for life itself which Morris considered the only possible form of human redemption.

For Morris then-more than for most other Victorian poets-moral(istic) judgments of female sexuality were irrelevant, and the dignified women of the early poetry eluded Victorian sexual codes. Morris's men and women embodied qualities equally necessary for life: judgment and strength must be informed by passion and beauty, grace and intensity by perseverance and loyalty. His characters' struggles to reunite these complementary qualities witnessed the needless tragedy of their separation. In later life, Morris's actions and writings showed consistent respect for women's rights of private judgment and recognition of their equal dignity of perception, character, and human endeavor.

42. Carol Poston, ed., A Vindication of the Rights of Woman by Mary Wollstonecraft (New York: Norton, 1988), chap. 4, “'Educate women like men', says Rousseau, 'and the more they resemble our sex the less power will they have over us.' This is the very point I aim at. I do not wish them to have power over men; but over themselves."

43. Wilfrid Scawen Blunt, My Diaries, 229. 
Morris, in short, portrayed forms of psychological and physical confinement of women that his male contemporaries often ignored, and the "romantic" predicaments of the women in The Defence reflected deeper forms of human alienation that he tried to remedy in several ways during his active life. Men too were victimized in Morris's poetry, but the suffering of the women was often more vivid, and more urgently demanded redress. To Victorian debates about the nature of sexual roles, Morris's poetry contributed an appreciation of the psychological intensity and depth of women's experience, and a characteristic awareness that social injustice always falls with greatest weight on those who are permitted the least defense.

\section{A “political” guenevere}

Morris's best known poetic creation has always been the title character of "The Defence of Guenevere," and I will argue in this section that his suspension of judgment about Guenevere's alleged 'crime' anticipated the openended and plurally interpretable qualities of his later work.

Any student of literary history is likely to agree with Hans Robert Jauss's observation that "the understanding of [a text's] first reader will be sustained and enriched in a chain of receptions from generation to generation." ${ }^{44}$ Late-twentieth- and twenty-first-century interpretations of the impasses and dilemmas confronted by Morris's 'medieval' women are no exception. The figure of Guenevere, in particular, has been subjected to an enormous variety of moral, thematic, historical, linguistic, rhetorical, deconstructive, and logical-positivist (!) interpretations of her situation and responses, and these interpretations have given rise to a bewildering array of glosses of her "defence."

In my personal role as an annual reviewer of Pre-Raphaelite criticism for Victorian Poetry for more than twenty-five years, I have encountered a wide range of (over-)interpretations that derive disparate conclusions from the text's modest evidentiary base, among them the following: ${ }^{45}$

44. "The reappropriation of past works occurs simultaneously with the perpetual mediation of past and present art and of traditional evaluation and current literary attempts" ("Literary History as a Challenge to Literary Theory," in Norton Anthology of Theory and Criticism, ed. Vincent Leitch, 1552).

45. "The Year's Work in Victorian Poetry: The Pre-Raphaelites" is published annually in the fall issue of Victorian Poetry, and my reviews have appeared during the period 1988-2015. 
1. Since adultery of a king's wife was legally defined as "treason" in medieval England, Guenevere's "defence" was an extended legal attempt to prove that her (tacitly acknowledged) affair was not "treasonous."

2. Guenevere's specious arguments bought time for Launcelot to rescue her, but her disjointed presentation gave evidence of deep repression and betrayed a fundamental dishonesty.

3. Guenevere's "defence" was a masterpiece of indirection and mendacity, comparable to the self-deconstruction of the casuistical wife-murderer in Browning's "My Last Duchess."

4. Guenevere's monologue reconciled incompatible aspects of Malory's sexually active / faithful platonic lover in a composite figure who was innocent of the immediate charge against her (sleeping with one of the wounded knights), but guilty of others which remained unspoken.

5. Guenevere violated canons of realism as well as common sense: no real woman would have been so foolish as to argue that her beauty exonerated her, or declare her love for Launcelot in front of a jury of her accusers (an assertion that might have surprised the authors of Mary Barton [1848] and Shirley [1849]).

6. Guenevere was a narcissist who displayed herself before her male judges in an attempt to seduce them, and her lies, indirections, and self-serving appeals to 'womanly' weaknesses embodied vitiated stereotypes of Victorian femininity as well as Morris's personal sensibility.

7. Guenevere's desperate assertion that "Nevertheless you, O Sir Gawaine, lie / Whatever may have happened through all these years, / God knows I speak truth, saying that you lie," appealed to a profound higher truth of the human heart.

8. Guenevere's tour de force transcended referents of language and identity, fixity and purpose, and its rhetoric of dissolving and undecidable meanings made "lying" in conventional senses irrelevant, and the craft of her persuasive power more admirable.

9. (my personal view) Morris conceived Guenevere's Defence in part at least as a critique of arranged marriages, sexual double standards, repressive social hierarchies, and "Arthur's great name and . . . little love," as well as an oblique comment on Robert Bulwer-Lytton's "Clytemnestra" (1855) and the contemporary debates that preceded passage of the Matrimonial Causes Act of 1857 .

The personal quality of some of these readings is hardly surprising, given Jauss's observation, but their variety also bears witness to the poem's shift- 
ing and ambiguous representations of Guenevere's moral and sexual poetic 'identity'.

Feminist critics and gender-theorists are well aware of this overdetermination. Eve Sedgwick, for example, argued that "sex, gender, sexuality [are] three terms whose usage relations and analytical relations are almost irredeemably slippery", 46 and Judith Butler that "gender" is also "performative," "as in other ritual social dramas, [and in that sense is a] . . repeated. . . [form of] public action," ${ }^{47}$ so much so that the "identity [so] tenuously constituted ... [becomes] a regulatory fiction." ${ }^{48}$ In the film theorist Laura Mulvey's well-known view, sexual variants of such "identit[ies]" became "projection[s] of repressed desire onto the performer[s],"49 but later critics have argued that this interpretation oversimplifies the motives and responses of the viewer as well as the viewed. ${ }^{50}$

Be that as it may, several of Morris's more complex women-early and late-experienced their own (command) "performances" as severely constrained agents of their fate. But some of his narratives' more complex menethically called to engage the world in direct action but rendered powerless by ambivalent forms of stoic fidelity-accepted comparably constricting attachments to these constrained women as they faced grim catastrophes that would overwhelm their lovers as well as themselves.

\section{ThE DEFENCE AND THE PILGRIMS OF HOPE}

The three best known poems of The Defence of Guenevere-the volume's title poem, "King Arthur's Tomb" and "The Haystack in the Floods"-presented enigmatic heroines confined physically and psychologically and threatened with death.

Guenevere, of course, is the most voluble and highly "performative" of these women, from the initial moment in which she mocks the "great lords"

46. The Epistemology of the Closet (Berkeley: University of California Press), 8.

47. Judith Butler, Gender Trouble, 140.

48. Ibid.

49. "Visual Pleasure and Narrative Cinema" (1975), in Film Theory and Criticism, 833-44.

50. For qualifications of Mulvey's argument, cf. Mary Ann Doane, "Film and the Masquerade: Theorizing the Female Spectator" (1982), in Feminist Film Theory, ed. Sue Thornham (New York: New York University Press, 1999), 131-45; Miriam Hansen, "Pleasure, Ambivalence, Identification: Valentino and Female Spectatorship" (1986), in Braudy and Cohen, 584-601; and Linda Williams, Hard Core: Power, Pleasure and the Frenzy of the Invisible (Berkeley: University of California Press, 1989). 
who judge her and imagines a symbolic bedchamber scene in which an angel bears "choosing cloths," to the scene in which she gathers strength to speak "out at last with no more trace of shame, / With passionate twisting of her body there" (11. 59-60). She literally dances in re-enactment of her erotic arousal in a walled garden where the boundaries of her psychic and gendered body dissolve into the sunlight (". . . what should I have done, / If this [my hand] had joined with yellow spotted singers, / And startling green drawn upwards by the sun?" [(11. 125-27]).

More striking perhaps is the passage in which the self-regarding mirror of her own self-image_-"my eyes," "my breast," "my arms," "my full heart," "my long throat," "my hands," "my moving tresses," "my face"-breaks into disparate shards and natural processes- "Wept all away to gray," "Like waves of purple sea," "Within my moving tresses." These attributes are the source of her power as well as her danger to herself:

... see my breast rise,

Like waves of purple sea, as here I stand;

And how my arms are moved in wonderful wise,

"Yea also at my full heart's strong command,

See through my long throat how the words go up

In ripples to my mouth; how in my hand

"The shadow lies like wine within a cup

Of marvellously colour'd gold; yea now

This little wind is rising, look you up,

"And wonder how the light is falling so

Within my moving tresses: ..." (11. 226-36)

This is performance, all right, but a threatened one, which brings forth its enthusiastic male narrator's "defence" ("Though still she stood right up, and never shrunk, / But spoke on bravely, glorious lady fair!” 11. 55-56), and that of her traditional champion Launcelot at the poem's end. (Notice, however, that she remains "glorious lady fair!" not "glorious lady strong!" or "glorious lady good!")

The elements of this self-portrait are oddly remote from conventional images of sexual beauty, however. Even the more obviously erotic descriptions ("see my breast rise / Like waves of purple sea") have a strangely impersonal quality (not "see how I move my arms" or "how I speak," but "see how 
my arms are moved in wonderful wise ... how the words go up in ripples to my mouth"). Such language suggests that Guenevere represents a generalized force of natural goodness, an alignment of id and superego that curiously lacks an ego. Her "face with no lie there / For ever" also provides a "gracious proof" that innocence of spirit can embody itself in an appropriate outer form. This near-Keatsian assimilation of beauty to truth is obviously circular in its celebration of "beauty" as a heterosexual life force, but it also provides a kind of abstract formal pattern of human emotions under stress. After these lines the epiphanic vision fades, but for the first time Guenevere remains conscious of her own dignity in the face of acute fear and likely death.

In the next passage, Guenevere recalls her last tryst with Launcelot, but refuses to repeat his parting words: "By God! I will not tell you more to-day, / Judge any way you will-what matters it?" (277-78). Launcelot's last words, of course, may have included a promise of the rescue that will follow (as they had in Malory). But her defiant reticence also expresses her claim to privacy and autonomy. She stands exposed to derision and judgment, and will hold private her last conversation with her lover, if necessary to death. Accordingly, she will contribute no more to her own defense: she can remember "all, all, verily, / But just that which would save me; these things flit" (ll. 281-82). Alternately, it might be argued that her "defence" leads naturally to this silence, a form of emancipation from her accusers. In the end their judgments do not matter to her, or to Morris, and she refuses to yield further to their compulsion.

After all this, there is admittedly something anticlimactic, if opportune, about Launcelot's subsequent arrival on a "roan charger" at "headlong speed," a kind of eques ex machina who quickly but abruptly concludes the physical action of the poem. Guenevere has already won her psychological independence, after which the narrative conveniently provides a form of external confirmation-the "judgment of God." Appropriately, too, for the first time in the poem, Guenevere's physical movements embody happiness in simple ways: "She lean'd eagerly, / And gave a slight spring sometimes." Such small human motions are consistent with the earlier idealized descriptions ("she stood right up, and never shrank / But spake on bravely ...”), but also less 'iconic' and more natural than the earlier near-apotheosis of Guenevere as the "glorious lady fair."

When Guenevere lifts her eyes to confront her accusers, at first it is only in flashes that she speaks with conviction, analytical power, or persuasive insight. But the insights do come, and at her best-during her brief quasitransfiguration as a force of beauty-within-nature-she becomes an archetypal voice of liberation from the crippling social and sexual constraints that closed in on Victorian women like a vise. 
In this sense, Morris's poem is a genuine vindication of a limited but admirable female psyche. Her "defence" is really twofold: that mercy is justice for those whose natural desires have been repressed; and a stronger one, that those who seem to require forgiveness may represent forces more natural and vital than those who "forgive" them. When Guenevere consciously identifies her passionate energies with the elements of nature and an idealized sanctity of natural emotion, her real self grows in dignity, self-respect, and strength.

The Guenevere of "King Arthur's Tomb" is vulnerable to threats of a darker and more deeply ambivalent nature, as her identity unravels in a series of disjointed tableaux. In the poem's opening lines, Launcelot recalls a scene charged with the colors and sounds of mystery:

... And she would let me wind

"Her hair around my neck so that it fell

Upon my red robe, strange in the twilight

With many unnamed colours, till the bell

Of her mouth on my cheek sent a delight

“Through all my ways of being ...” (11. 44-49)

One of The Defence's many women who reveal intense emotion through radically unorthodox prayers, she kneels before a crucifix and recalls the first lover of her beauty:

... dost thou reck

“That am I beautiful, Lord, even as you

And your dear Mother? why did I forget

You were so beautiful, and good, and true,

That you loved me so, Guenevere? O yet

"If even I go to hell, I cannot choose

But love you, Christ, yea, though I cannot keep

From loving Launcelot. ..." (11. 168-75)

Rent by irreconcilable loyalties, and perhaps unable to trust herself, in the climactic encounter at Arthur's grave Guenevere savagely mocks the "twisting knight" who sought to kiss her in farewell: 
"Across my husband's head, fair Launcelot!

Fair serpent mark'd with V upon the head!

This thing we did while yet he was alive,

Why not, O twisting knight now he is dead?" (1l. 207-11)

Launcelot, stunned, awakens later to the sound of a "bell" some have interpreted as a call to repentance, and others as the death-knell of his distraught lover. Some of my more religious students have interpreted Guenevere's part in this interchange as a kind of harsh appeal to Launcelot's conscience-a defensible reading, but difficult to reconcile with Morris's lifelong respect for the meeting of true souls. Instead the narrator's sympathies seem to lie with Launcelot as he recoils in shock:

"Yea, she is mad: thy heavy law, O Lord,

Is very tight about her now, and grips

Her poor heart, so that no right word

“Can reach her mouth. ..." (11. 198-201)

His reaction is understandable given the bleakness of Guenevere's physical demeanor:

$$
\text { ... a blight }
$$

Had settled on her, all her robes were black,

With a long white veil only; she went slow,

As one walks to be slain, her eyes did lack

Half her old glory, yea, alas! the glow

Had left her face and hands. ... (11. 128-33)

Guenevere is a victim of her society's moral code, now internalized as her own obsessions: "Didst ever think queens held their truth for dear?" (1. 264). Significantly this code has been interpellated through the hostile and gossiping hostility of those who surround her-the priest warns of divine retribution, her maids condemn her, and she is frightened at her vulnerability when even a passing churl snarls at her. The narrator, by contrast, seeks to "think bigly and kindly" of all aspects of human passion, repentance, scission, and despair. 
In "The Haystack in the Floods", another tale of two lovers with interdependent fates in the interstices of Froissart's accounts, ${ }^{51}$ Jehane, who had "come all the way for this / To part at last without a kiss" (1l. 1-2), is confronted with an extortive 'choice': death of her lover (Robert) or acquiescence to the advances of his murderer (Godmar), and her decision is determined by her desire to preserve as much personal integrity as possible.

The poem's opening lines focus on Jehane's physical state as she and Robert desperately try to escape their pursuers:

Upon her head and heavy hair,

And on her eyelids broad and fair

The tears and rain ran down her face. (11. 12-14)

Suddenly confronted by thirty armed men, they respond in keeping with their respective characters. Fully aware that his death is imminent, Robert gallantly evokes a more distant prospect: "[W]hy, sweet my love good cheer. / The Gascon frontier is so near, / Nought after this" (ll. 46-48), and Jehane confronts her 'choice':

My God! my God! I have to tread

The long way back without you; then

The court at Paris; those six men;

The gratings of the Chatelet;

The swift Seine on some rainy day

Like this, and people standing by,

And laughing, while my weak hands try

To recollect how strong men swim.

All this, or else a life with him,

For which I should be damned at last. (11. 49-59)

Faced with this fate, Jehane "strangely childlike came, and said: 'I will not" (1. 126), and the poem's spare, swift tetrameters hasten its brutal ending:

51. The poem is dated by its reference to the battle of Poictiers, which occurred 22 September 1356. Robert of Marney was an Englishman who flourished during the reign of Edward III. A Godmar du Fay appears in Froissart, where his name is associated with treachery and incompetence. He fought against Edward III at the battle of Blanchtaque, which was conducted in a flooded field, and after he realized his armies would be defeated, he fled, leaving his men to be killed (vol. 1, chap. 291-92). He was also blamed by the French king for the defeat at Crècy in 1346 (vol. 1, chap. 134). See John M. Patrick, "Morris and Froissart Again: 'Sir Peter Harpdon's End,'” 331-33. 
... she saw [Godmar] send

The thin steel down; the blow told well,

Right backward the knight Robert fell

And moan'd as dogs do, being half dead,

Unwitting, as I deem: so then

Godmar turn'd grinning to his men

Who ran, some five or six, and beat

His head to pieces at their feet. (ll. 144-51)

At the end of this butchery, Jehane "shook her head and gazed awhile / At her cold hands with a rueful smile, / As though this thing had made her mad" (ll. 156-58), and the poem concludes with a tracking shot of "the parting that they had / Beside the haystack in the floods."

Such portraits of intractable dilemmas pose a comparably intractable question: is it possible to define a 'right thing' in such situations, and at what human cost? Morris's sympathies for Guenevere and Jehane in such situations are clear, but the answers to the questions they pose are not.

In the fourth chapter of "The Pilgrims of Hope," Morris's last long narrative poem, he crafted his most extended dramatic monologue for a female speaker, spoken to her infant son who is too young to understand her, and thus by implication to the reader. A political revolutionary and Communard facing possible death ("never again in my life shall I dare to speak to thee thus," 152$)^{52}$ - she describes to him her past as a rural foundling, and the ideals she shares with his "fair and fierce" father. In keeping with her political commitments, she formulates a socialist-feminist critique of Victorian marriage ("Some are there born of hate, many the children of greed," 152), and her hopes are the more poignant for their counterfactuality, for she will soon die on the barricades (in her husband Richard's words, she was “. . . gone. She was and she is not; there is no such thing on the earth / But e'en as a picture painted. ..."). ${ }^{53}$ Her wistful expression of love for her future son-which might be described as emotion anticipated in tranquility-lives on only in Richard's love for him.

52. CW, 9:151; "The Pilgrims of Hope" was published in Commonweal in 1885-86; the "Mother and Son" section was included in Poems by the Way, and the entire poem in CW, vol. 24; a separate edition of The Pilgrims of Hope and Chants for Socialists was issued by Longmans and Green in 1915.

53. Bk. 8, "The Half of Life Gone," in Three Works by William Morris, ed. A. L. Morton, 154. 


\section{ONCLUSION}

Early and late, Morris came out fairly well in the spectrum of mid-Victorian literary debates about 'the' nature and role of women, and in his creation of Guenevere, his contempt for hypocrisy and temperamental identification with victims of convention created one of the better mid-Victorian vindications of a besieged woman's right of self-determination. Apart from the Brownings, no major poets of the 1850 s permitted their heroines to indict the straitened circumstances of their lives with anything like this force, much less align their response with a liberating force of nature. For women denied personal autonomy in mid-nineteenth-century England, a poetic heroine who tried to break free of such constraints-however 'spasmodically'-may have been an attractive figure.

Morris's contribution to the sparse list of monologues in women's voices crafted by major male poets (Tennyson's “Oenone," Robert Browning's "Pompilia," and Swinburne's "Anactoria" come readily to mind) benefited from his egalitarianism, his diffuse eroticism, and an empathetic willingness to interpret sexually charged ethical conflicts in private as well as public terms. ${ }^{54} \mathrm{His}$ speakers' embodiment of the pleasures and pains of heterosexuality and, in later works, maternity, also anticipated the isolation, fractured identity, and threatened autonomy of other portrayals by late-Victorian contemporaries such as Amy Levy's "Xantippe” and Rosamund Marriott Watson's “The Ballad of the Bird-Bride."

Morris's readers remember his women, I believe, because they were complex figures whose diapason of desire, empathy, sympathy, identification, anxiety, judgment, and veiled revulsion elicit complex responses. They reflect an empathetic heterosexual man's efforts to understand their dilemmas from 'within' as well as 'without.' However stereotyped and projective these projections may have been at times, at others they were surprising and sometimes convincing (otherwise they would be ignored). His modeling of dignified heroines who proclaimed their own values in ethically charged situations also ensured that their dilemmas remained at least in part beyond judgment, and thus subject to reinterpretation by successive audiences long after his death.

54. Carole Silver suggests that "Morris cannot bring his divided self into unity, his poems are full of internal drama and well-created tensions," Romance of William Morris, (45). I would add that "unity" was rendered more difficult by the range of his political sympathies and willingness to examine received ethical norms. 
In later years Morris was more immediately preoccupied with women's freedom from physical violence and economic constraints than with access to education, the franchise, and other 'bourgeois privileges'-a controversial position held by other socialist feminists of the time, including Eleanor Marx. ${ }^{55}$ But his emotional and conceptual egalitarianism prompted him to see moral agents from many angles of incidence, and deepened and nuanced his responses to sexual violence-not only violence against women and other violations of human dignity, but the mysterious entanglements of rage and aggression in baffled attractions for and between members of both sexes.

His views and representations of these baffles and entanglements also evolved-not surprisingly-with maturity and experience: with the parenting of two daughters; with changes in his own and other Victorians' views of women, and with the complex personal imbroglio of his own marriage. His female monologists were persuasive in their very incompletion, as this early poetic champion of tormented heroines' struggles for autonomy sought a broader view of 'fellowship' that would embrace "woman as she shall be." His literary imagination was broader than his ideology, and his ideology was broader than most.

55. See Florence and William Boos, "An (Almost) Egalitarian Sage: William Morris's Later Writings and 'The Woman Question," in Victorian Sages and Cultural Discourse: Renegotiating Gender and Power, ed. Thais Morgan (Rutgers: Rutgers University Press, 1990), 187-206, 296-301; and Florence Boos, "Gender Division and Political Allegory in The Sundering Flood," Journal of Pre-Raphaelite Studies 1.2 (1992): 12-23. 


\section{eight}

\section{FTER THE DEFENCE}

\section{A MORE AUTHENTIC “MEDIEVALISM"}

he Defence of Guenevere is generally recognized as one of the best single volumes of Victorian poetry. I have argued that Morris's earliest poems offered talented expressions of a sensitive late adolescence, but they do not explain the sophistication that accrued to him as he wrote The Defence. The question-why these vast changes? - cannot be answered fully; but one can observe the nature of the shifts and the events that occurred in the interim.

Later recollections of Morris's attendance at Oxford University consistently identify this period with the formation of his ideals of a life devoted to art and social justice, and establishment of deep ties to others devoted to these ends. As we have seen, friendship was more significant to Morris than to most people, and at Oxford or shortly afterward he formed several friendships that continued into the Firm, the Socialist League, and his familial and recreational life. In a lecture, William Morris and His Circle, delivered eight years after the publication of his biography of Morris, J. W. Mackail provided a dramatic but essentially accurate view of the effect upon Morris of his Oxford friendships and the shared interests of his circle:

In Morris ... two years wrought a silent, swift, and profound change. AngloCatholicism fell off him like an outworn garment, like the husk from an 
expanding bud. ... The Brotherhood broke up the monastic element in [his original] ideal; its ascetic element ... melted away in the wider, larger, opener air now let in upon him.... His favourite reading had been in Christian antiquities and Anglo-Catholic theology. The whole of history and literature now broke open before him; and through it all, as its central spirit and vital essence, ran the golden thread of art. ${ }^{1}$

His courtship and forthcoming marriage were significant aspects of Morris's maturation, as shown by the greater psychological acuity and intensity of his portrayal of romantic and sexual relationships in his 1858 volume, as compared with the 1856 prose romances. As the preceding chapters have shown, in the choice of models for his writing, during this period Morris gradually broadened his knowledge of modern literature from romantic medievalizers such as Friedrich De La Motte Fouqué and contemporary novelists such as Charlotte Yonge and Charles Kingsley, to serious study of the contemporary heirs of the romantic movement-among them Tennyson, Browning, Rossetti, and Owen Meredith / Robert Bulwer-Lytton. He also read extensively and systematically original texts of medieval literature, including countless songs, carols, and legends, as well as sophisticated blends of myth and fantasy such as Malory's Morte d'Arthur and chronicles of brutal fact laced with partisan commentary such as Froissart's Chronicles.

Morris's increasingly secular views enabled him to clarify his relationship to medieval religious lore, perceived as material of immense cultural interest whose belief structure required reinterpretation as symbol and myth. In addition, the depth of his friendships-continued as a matter of course as circumstances permitted throughout later life-as well as the experience of romantic love, led him to define isolation and disloyalty as the most troubling human conditions, and prompted an interest in the psychology of intimate attachments. These views provided the ethic that, as we have seen, dominated the tone and narratives of The Defence, though it is the pain of isolation and rejection rather than the consolations of love and community that are represented most frequently.

The succeeding years were to test Morris's ability to negotiate the mixed reception of his poetry, break free from the direct influence of his literary antecedents, and persevere in the arduous, though ultimately successful, pursuit of a mature, reflective, and inclusive style.

1. Mackail, William Morris and His Circle, 8-9. Mackail may be slightly conflating his account of the two friends; though reportedly Edward Burne-Jones read avidly in AngloCatholic theology, Morris's medieval reading seems to have been less overtly religious in focus. 


\section{EVIEWERS AND READERS}

Although an obscure first volume by a little-known twenty-four-year-old poet, The Defence found its share of reviews-in prominent periodicals such as the Athenaeum, the Spectator, the Saturday Review, and Fraser's Magazine, as well as lesser organs such as the Tablet, the Literary Gazette, and the Ecclesiastic and Theologian. At least four of these reviews were hostile-those in the Spectator, Athenaeum, and Saturday Review can only be described as churlish-and most of the favorable ones were also full of censure and unsolicited advice. Morris "learned" from some but not all of this advice, and accepted only those censures that reinforced his natural inclinations.

Much of the explanation for the great attention as well as disapprobation heaped on the young poet has been identified by Peter Faulkner, who notes that The Defence of Guenevere was the first book of poetry associated with Pre-Raphaelitism, appearing before the publication of any volumes by D. G. Rossetti, Swinburne, or Christina Rossetti. In Faulkner's words: "Rossetti led his poetic army from the rear, while Morris paid the price of being in the van." ${ }^{2}$ The bold dedication: "To My Friend Dante Gabriel Rossetti, Painter" significantly omitted from Morris's Kelmscott Press edition in 1892-also directed attention to Rossetti, at the time a controversial figure in art, and to the still radical and unconventional school of Pre-Raphaelite painting. Almost all of the reviewers took pains to situate Morris in the sights of their general views of Pre-Raphaelitism, neutral, unfavorable, or admiring:

The dedication ... suggests already the Pre-Rafaelite sympathies of the author, and the book itself fully establishes them. ${ }^{3}$

"Golden Wings" ... seems to conduct us through a long gallery of Mr. Rossetti's works, with all their richness of colouring, depth of pathos, poetical but eccentric conception, and loving elaboration of every minute detail. After all, those who have read the beautiful poems, contributed by the painter to the defunct Oxford and Cambridge Magazine, will probably think this dissertation and Mr. Morris' dedication equally superfluous. ${ }^{4}$

2. Peter Faulkner, ed., The Critical Heritage, 6. See also John Schofield, "The Defence of Guenevere and Contemporary Critics."

3. Unsigned review, Tablet, April 1858, xix, 266.

4. Garnett, Literary Gazette, 6 March 1858, xlii 226. 
While we were looking . . . at Mr. Egley's skilful, minute, yet barely intelligible, presentment of ["The Lady of Shalott"] —something of sympathy, something of sadness, something of wonder, came over us, in consideration of time wasted and effort ill bestowed. This, however, the Pre-Raphaelite poets, apparently, do not perceive, otherwise, we should never have been bidden to look on so astounding a picture as Mr. Morris' "Rapunzel."5

One reviewer, Richard Garnett, rather gallantly identified Morris himself as a painter:

We do not hesitate to pronounce, that if he do but wield the brush to half as much purpose as the pen, his must be pictures well worth a long pilgrimage to see. ${ }^{6}$

As a corollary of this identification with the Pre-Raphaelite movement, one critic seized the occasion to launch a lengthy attack on the supposed features of Pre-Raphaelitism which bore little apparent relevance to Morris's volume:

But when painters think it their duty to work through a microscope, and to try to paint every stain on every leaf, as well as every leaf on every tree, they not only forget what art is, but are ignorant of what artistic imitation is. This extravagance is, we think, what Mr. Morris delights in. He works in the patient spirit of the illuminators, but then he is grotesque as well as minute and patient.?

Not only did Morris run the gauntlet of reviewers' prior views on contemporary art, he was also assessed as a placeholder for their views of his predecessors:

To describe any one as Rossetti plus Browning, is as much as to say that he is not a little affected and obscure. ${ }^{8}$

5. H. F. Chorley, unsigned review, Athenaeum, 3 April 1858, no. 1588, 427.

6. Garnett, Literary Gazette, 6 March 1858, xlii 226. This may allude to the fact that during 1856 and 1857 Morris had attempted painting under Rossetti's tutelage, producing "La Belle Iseult" and at least one other now lost painting. See Jan Marsh, "La Belle Iseult."

7. Unsigned review, Saturday Review, 20 November 1858, vi, 506-7. The word "grotesque" has since been revived by Isobel Armstrong, to denote some of the work's Ruskinian ethical critique of medieval (and by implication) Victorian social conditions: see "A New Radical Aesthetic, The Grotesque as Cultural Critique: Morris."

8. Garnett, Literary Gazette, 6 March, 1858, xlii, 226. 


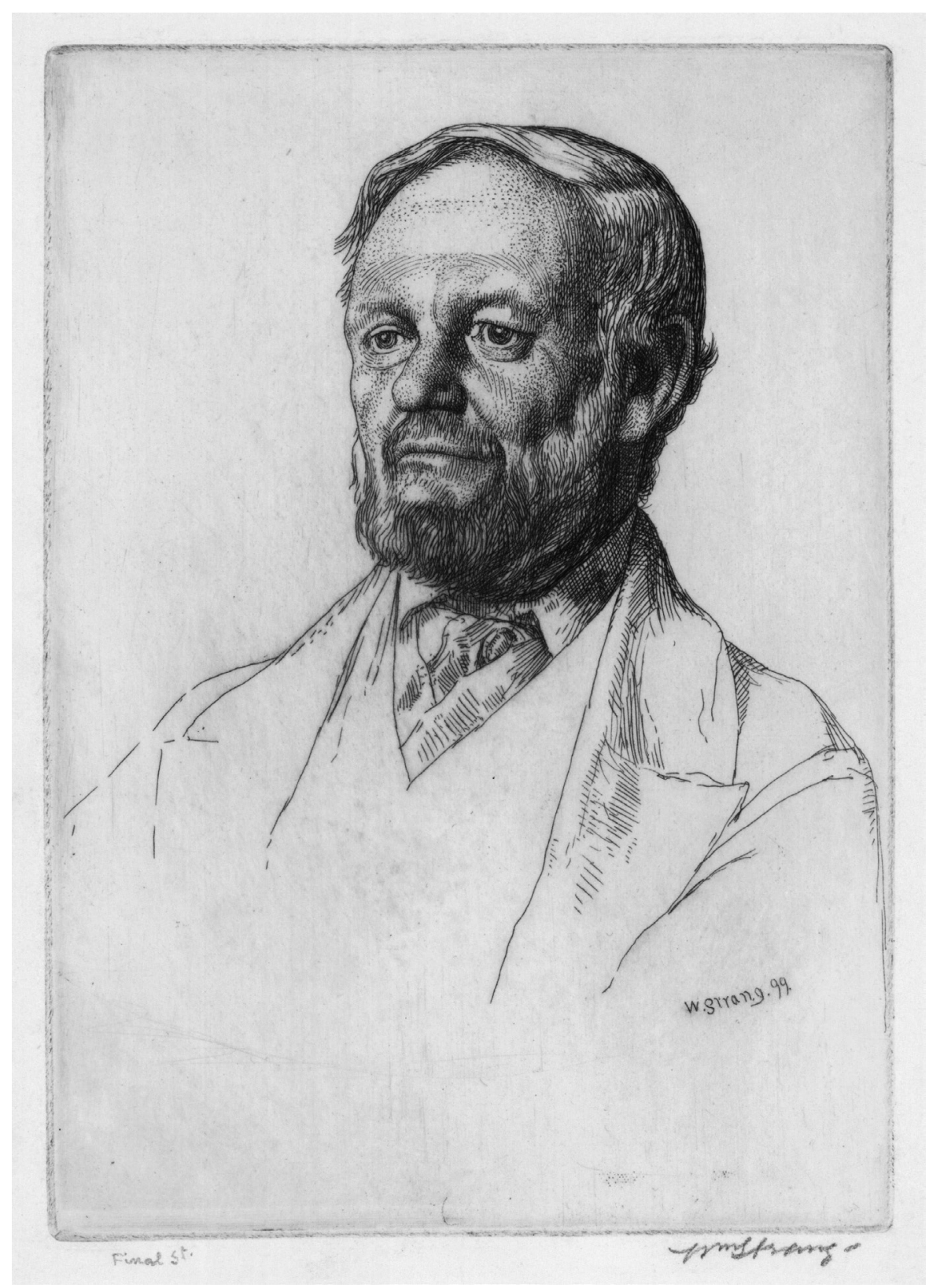

FIGURE 18. Richard Garnett. Courtesy of the National Portrait Gallery. 
"Sir Peter Harpdon's End" . . . as a whole ... reminds us considerably of Mr. Robert Browning's writings. . . . "The Wind” . . . reminds us in a general way of many [modern writers]. Shelley, Browning, Tennyson, and Bailey, all might have written it, still we venture to doubt if any would have been more successful than our author. ${ }^{9}$

In general, reviewers contrasted Morris's poetry with that of Tennyson, and compared it with Rossetti's art and Browning's poetry. One reference to Philip Bailey (author of the wildly popular Festus) by the reviewer for the Ecclesiastic and Theologian is a reminder of Morris's distant kinship with the socalled Spasmodics, a group of poets who had suffered the obloquy of William Edmonstone Aytoun's harsh parody, Firmilian, in $1854 .^{10}$

The poetry itself elicited a range of responses. "King Arthur's Tomb," for example, was described as "a really fine poem" and quoted at great length as the centerpiece of John Skelton's review in Fraser's Magazine," but evoked the following dismissal from the reviewer of the Ecclesiastic and Theologian:

It lacks unity of purpose, precision of expression, and, as indeed do many others, finish of execution. There are one or two powerful descriptions, and an expression here and there, which will not be easily forgotten; but on the whole, we prefer to skip over it as in many ways deficient. ${ }^{12}$

Even the mostly praiseful Richard Garnett had found one of the poems intolerable: “A little trouble will, perhaps, make 'Queen Guenevere's Defence' what it ought to be, but 'King Arthur's Tomb' will never be fit for anything but the fire."'13

Among the Malorian poems, "The Defence of Guenevere" failed to draw the attention visited on it in the twentieth century, and the Saturday Review critic was especially dismissive: "His chief poem is the 'Defence of Guenevere'-a very tedious affair, . . . as far as we can understand . . . a defence of the virtue of King Arthur's queen, a lady whose fair fame, like Helen's, it was reserved for our politeness to vindicate." ${ }^{\prime 14}$ Inverting the preferences of most

9. Ecclesiastic and Theologian, March 1858, vol. 20, 162, 168.

10. Florence Boos, "Class and the 'Spasmodics': W. E. Aytoun, George Gilfillan, Sydney Dobell and Alexander Smith," Victorian Poetry 42.5 (2005): 553-83.

11. John Skelton, "A Raid Among the Rhymers," Fraser's Magazine, June 1860, vol. 61, no. 366,828 .

12. Ecclesiastic and Theologian, March, 1858, vol. 20, 160 .

13. Garnett, Literary Gazette, 6 March 1858, xlii, 226-27.

14. Unsigned review, Saturday Review, 20 November, 1858, vi, 507. 
modern critics, several contemporary reviewers found much to praise in "Sir Galahad: A Christmas Mystery." The Ecclesiastic and Theologian reviewer, for example, who had found "The Defence of Guenevere" marred by "divers quaint expressions, an apparent attempt at obscurity and difficult writing," was delighted by "Sir Galahad," "the gem of the whole book":

Were it not too long for quotation, we would gladly give it entire, as it evinces very remarkable powers. . . Mr. Morris' Knight is a perfect picture: soul, body, heart, feelings, expression, words, and exterior thoroughly mediaeval, and all in perfect keeping, oneness and harmony. ${ }^{15}$

Richard Garnett, his most favorable early reviewer, wrote that "no fleck, happily, mars the pure beauty of 'Sir Galahad' and 'The Chapel in Lyoness', pieces in which the rough chivalry of the middle ages appears as it were transfigured, and shining with a saintly halo of inexpressible loveliness,"16 and the Tablet reviewer was content to "pass over 'Guenevere' and 'Lancelot" for a full account of "Sir Galahad" with citations, remarking of "The Chapel in Lyoness" that it "is very beautiful, and not unworthy of the companionship of Tennyson's 'Morte d'Arthur' and 'Sir Galahad.”' "Galahad” and "The Chapel in Lyoness" may have pleased in part because they celebrated a sympathetic and relatively uncomplicated Arthurian character, and in part because they placed fewer demands on critical sensibilities than the frayed emotions of Guenevere and Launcelot.

The comments of the two reviewers who sincerely admired Morris's volume showed insight into his intentions, and even into the nature of poetry itself. The first, the aforementioned Richard Garnett, was at the time of his review a twenty-three-year-old assistant at the British Museum library, and perhaps already a friend of the Rossetti brothers. In any case, as we have seen, his review demonstrated a precocious understanding of the relative merits of the Rossettis, Morris, and Tennyson: ${ }^{18}$

The difference between the two poets obviously is that Tennyson writes of mediaeval things like a modern, and Mr. Morris like a contemporary. Tennyson's "Sir Galahad" is Tennyson himself in an enthusiastic and devotional mood; Mr. Morris' is the actual champion, just as he lived and moved and

15. Ecclesiastic and Theologian, 1858, vol. 20, 160.

16. Garnett, Literary Gazette, 6 March 1858, xlii, 227.

17. Tablet, April 1858, xix, 266.

18. Alan Bell, Oxford Dictionary of National Biography (Oxford: Oxford University Press, 2004), 21:500. See also Barbara McCrimmon, Richard Garnett: The Scholar as Librarian. 
had his being some twelve hundred years ago. ... Tennyson is the modern par excellence, the man of his age; Rossetti and Morris are the men of the middle age; and while this at once places them in a position of inferiority as regards Tennyson, it increases their interest towards ourselves, as giving us what it would be vain to expect from any one else. ${ }^{19}$

Garnett anticipates later critics in selecting for praise one of the volume's Froissartian poems, "The Haystack in the Floods":

... where Mr. Morris' native romance and pathos unite with his model's passion and intensity to form a whole unsurpassed, we will venture to say, by any man save Tennyson, since the golden age of British poetry expired with Byron at Missolonghi. ${ }^{20}$

He is also the first to apply a bit of negative capability to the qualities of the work's more imaginative dream poems:

We are delighted with his poetry, but cannot very well tell what it is all about; "We see a light, but no man." This is particularly the case with those very remarkable pieces, "Golden Wings," "The Blue Closet," "Spell-bound," and "The Wind," in which it is true that something exciting happens, but as the courier in Little Dorrit has it, there is no why. ${ }^{21}$

The second favorable review, by the then-twenty-nine-year-old John Skelton (under the pseudonym of "Shirley," after Brontë's heroine), was published in Fraser's Magazine in July of 1869 as a conscious attempt to counter prior critics' excessive derision. Its author, a Scottish lawyer and critic who later wrote several defenses of Mary Queen of Scots (perhaps even more difficult to defend than Guenevere), showed considerable understanding of the sources of Morris's "obscurity" as well as an early insight into the aesthetics of photography: ${ }^{22}$

His obscurity arises from an intelligible cause. Most of his poems are soliloquies. To preserve the dramatic effect of a soliloquy, a previous acquaintance

19. Garnett, Literary Gazette, 6 March 1858, xlii, 226.

20. "The Haystack in the Floods" was also singled out in the Tablet, April 1858, xix, 266.

21. Garnett, Literary Gazette, xlii, 227.

22. John Skelton (1831-97) continued his defense of the Scottish queen into four volumes: The Impeachment of Mary Stuart (1876), Essays in Romance and Studies from Life (1883), Maitland of Lethington and the Scotland of Mary Stuart (1887-88), and Mary Stuart (1893). See the Oxford Dictionary of National Biography, 50:840; the article notes that "In his historical work he characteristically displayed something of the spirit of the advocate." 
with the circumstances must be presumed. . . The speaker would become unnaturally prosy were he to give a minute narrative of his antecedents. $\mathrm{He}$ cannot be permitted to rehearse his autobiography. He must plunge abruptly into the heart of the story. Mr. Morris has perceived this necessity . . parts of the picture are sure to be rendered vividly; as in a photograph, where, though the edges may be blurred and blotted, some feature starts out with life-like distinctness. ${ }^{23}$

Skelton likewise perceived a justification for the poem's alleged roughness of language:

It is [the poet's] delight to contend with rude forms and harsh associations, and to contrast their native pith and vigour with the elegant and polished feebleness of their rivals. This frame of mind may be slightly irrational, but is not altogether incomprehensible ... the result, notwithstanding the occasional quaintness and uncouthness, is certainly effective. ${ }^{24}$

Skelton also singled out as a feature of Morris's volume its use of strongly symbolic coloration, an attribute identified by more recent critics such as Carole Silver and Elizabeth Helsinger:

It is always, in like manner, the colour of an object which first attracts $\mathrm{Mr}$. Morris' eye. He falls in love with the golden hair of his heroines, before he marks whether they are tall or short, ugly or beautiful. The green and gold and purple and scarlet which Mr. Rossetti uses are reproduced in his poems. [cites nine stanzas from "Golden Wings"] ${ }^{25}$

Skelton's praiseful review of Morris was conjoined with a scathing dismissal of a volume by Professor John Stuart Blackie, a fellow Scotsman who enjoyed a wide popular following:

Despising rhyme and reason, art and design, the Professor in like manner has "skelpet on through mud and mire" from the beginning to the end of his ride. . In every page a passion is torn to tatters, ${ }^{26}$

23. "Shirley," Fraser's Magazine, June 1860, vol. 61, 825.

24. Ibid.

25. Ibid., 824 .

26. Ibid., 814. Some of his ire is political; Skelton lampoons Blackie for his melodramatic appeals for revolution: "He is distinctly of the opinion (and at least in avowed, if not sober prose) that it is the duty of the patriot to assassinate his tyrant" (816-17). He concludes sarcastically: "in bidding him farewell, can we do so more affectionately than in his own words? The age is full of talkers. Thou / Be silent for a season" (818). Elizabeth Barrett Browning is described 
and an expression of disappointment in Elizabeth Barrett Browning's Casa Guidi Windows ("grave literary and political sins have been committed by one to whom our literature owes much"), so his praise was not easily won. Even more strikingly, it was, at least in part, grounded in considerations that were ethical and intellectual as well as aesthetic:

If Mr. Morris be a fair representative of our younger poets, we may look forward with hope to the future. For something consistently good may be expected by and by from men who, resisting the sensuous seductions of poetry, are willing to expend upon their work moral seriousness and intellectual effort. ${ }^{27}$

Years later, in his reminiscences, The Table Talk of Shirley (1895), Skelton recalled that he had argued with the editor of Fraser's Magazine, John Parker, for permission to include his review, quoting from a letter from the latter on the topic: "For myself, I am sick of Rossetti and his whole school. I think them essentially unmanly, effeminate, mystical, affected, and obscure. You ought really to say more as to Morris' obscurity and affectation." ${ }^{28}$

One matter on which all the reviewers seemed to agree-for better or worse-was The Defence's originality, a throwaway judgment for most, but for the others a striking merit:

In the "Defence of Guenevere," there is evidence enough both of the originality, force of expression, and power of composition which the author possesses. . . . his present volume evidences the possession of very unmistakeable originality. . . ${ }^{29}$

There is amazing variety in this volume, but there is power everywhere, whether the poet recounts ancient legends or sings of knightly deeds,

as "a true poet ... endowed with a powerful and truthful imagination," but the reviewer regrets her praise of Louis-Napoleon Bonaparte's (Napoleon III's) conquest of Italy, for "it is base and unnatural ... when the poet ... follows a despot in his triumph" (820).

27. Fraser's Magazine, June 1860, vol. 61, 828.

28. 14 May 1860. The entire passage is interesting. Parker had declined to publish Morris's poems, noting that "Surely 19-2oths of them are of the most obscure, watery, mystical, affected stuff possible. The man who brought the MS. (himself well known as a poet) said 'that one of the poems which described a picture of Rossetti was a very fine poem; that the picture was not understandable, and the poem made it no clearer, but that it was a fine poem nevertheless'" (The Table Talk of Shirley [Edinburgh: Blackwood, 1895], 79). The poem referred to would have been "The Blue Closet" or "The Tune of Seven Towers," and one wonders who this "well-known" intermediary may have been (perhaps William Bell Scott?).

29. Ecclesiastic and Theologian, March 1858, vol. 20, 160, 169-70. 
whether he deals with mystery or magic, love and joy, or sorrow and despair. $^{30}$

In advocating the claims of an unknown poet to public attention, it is before all things necessary to establish his originality - a very easy matter in the present instance. . . Mr. Morris is an exquisite and original genius, a poet whom poets will love. ${ }^{31}$

Most also agreed that the volume's "medievalism" was unusually authenticonce again, for better or for worse:

The poet ... displays a most remarkable and praiseworthy knowledge of the details of the middle ages, as well as of the temper and habit of mind of those who flourished then. ${ }^{32}$

Nearly all the rest of the pieces belong to the vaguely fabulous age of chivalry; though the author has introduced into his poems touches of what modern research or judgment has shown to be its real coarseness and immorality. ${ }^{33}$

Mr. Morris never thinks of depicting man or life later than the Crusades. With him, the function of art was at an end when people began, in decent life, to read and write. ${ }^{34}$

The employment of antique words and habits is not formal or antiquarian only, but denotes a living insight into the thought and heart of the dead people whose life they shaped..$^{35}$

Tennyson is the orator who makes a speech for another; Mr. Morris the reporter who writes down what another man says. Whatever medievalists may assert, poetry flourishes far more in the nineteenth century than it ever did in the seventh; accordingly the Laureate is as superior in brilliance of phrase ... as he is inferior in dramatic propriety and couleur locale. ... Rossetti and Morris are the men of the middle age. ${ }^{36}$

30. Tablet, April 1858, xix, 266.

31. Literary Gazette, 6 March 1858, xlii, 227.

32. Ecclesiastic and Theologian, April 1858, vol.20, 160.

33. Unsigned notice, Spectator, February 1858, xxxi, 238.

34. Saturday Review, 20 November 1858 , vi, 507.

35. John Skelton, Fraser's Magazine 1860, vol. 61, 366, 824.

36. Garnett, Literary Gazette, March 1858, xlii, 227. 
A third point of agreement was the need for greater clarity and less "obscurity," a view shared by praisers and detractors alike:

Mr. Morris is obscure, mystical, and affected; and he may take our word for it, that the sooner he learns to speak clearly, simply, and in a natural tone of voice, the sooner will he command attention, and-deserve to command it. ${ }^{37}$

Each poem is as hard to decipher as though it were written in black letter. ${ }^{38}$

To describe any one as Rossetti plus Browning, is as much as to say that he is not a little affected and obscure. . . his carelessness and inattention to finish is his fault, and a serious one. . . We can only suppose Mr. Morris' frequent indifferent grammar, atrocious rhymes, and lines unscannable on any imaginable metrical system, to be the consequence of an entirely erroneous notion of poetry. ${ }^{39}$

[Had Morris not departed from the "furthest verge of Dream-land to which Fancy can penetrate"] we should never have been bidden to look on so astounding a picture as Mr. Morris' "Rapunzel." How to express or make the subject of this clear, is not an easy task. ${ }^{40}$

Let us warn Mr. Morris not to be led by the flattery of kind opinions of friends to imagine that obscurity and profundity are convertible terms. If a writer wishes to be understood, and has anything worth saying, let him put it into language that will be intelligible to an ordinary capacity. ${ }^{41}$

Some of this is hard to understand. The seemingly simple tale of "Rapunzel," for example, was selected by at least two reviewers as puzzling ${ }^{42}$ (as Richard Garnett quipped, “'Rapunzel' . . . will be a fearful stumbling-block to prosy people" 43 ), and the Tablet reviewer pointed out another possible cause:

37. John Skelton, Fraser's Magazine, 1860, vol. 61, 825 .

38. Saturday Review, 20 November 1858, vi, 507.

39. Garnett, Literary Gazette, 6 March 1858, xlii, 226.

40. H. F. Chorley, unsigned review, Athenaeum, 3 April 1858, no. 1588, 427.

41. Ecclesiastic and Theologian, March 1858, vol. 20, 169.

42. Athenaeum, 3 April 1858, 427, cited above, and Ecclesiastic and Theologian, March 1858, vol. 20, 169: "Rapunzel,' is a wild and romantic production, characterised by much indistinctness" (162). It also drew interest; Richard Garnett noted "its wild, weird beauty" (Literary Gazette, March 1858, xlii, 227), and John Skelton remarked on "the weird music of Rapunzel" (Fraser's Magazine, 1860, vol. 61, 828).

43. Literary Gazette, March 1858, xlii, 226-27. 
“'Rapunzel' and her golden hair will be a stumbling-block to those who did not know her in their nursery days, or who have not read her authentic history told by the Brothers Grimm." 44

In hindsight, such "obscurity" was also part of the quality of 'mystery' that made Morris's best poems attractive to a more limited audience. J. W. Mackail observed that it was the "poems taken straight out of dreamland" on which "the unjust praise and the blame not worth heeding which the volume drew on itself were primarily spent." As an amateur poet himself $f^{45}$ he also defended one of their special merits: "Never perhaps has poetry come nearer to what some theorists have laid down as its goal, the emotional effect of music, than in some of these remarkable pieces-'The Wind,' 'Spell-bound,' 'Near Avalon."' 46

Several generations later, Carole Silver remarked in very similar language that "[these poems] take place within the indeterminate medievalized world of fairyland. . . The light of dream shines over them all. Closest in spirit to Morris's early prose tales, they have the precise detail and conceptual ambiguity of stories like "The Hollow Land." ${ }^{47}$ And Elizabeth Helsinger found in them an evocative use of color that could "reawaken a sense of the strangeness and otherness of objects, of persons, and of past historical moments. For mid- and late-nineteenth-century poets, painters, and critics restless within the constraints of realism, colour was the way forward-a determining sign of the modern." ${ }^{48}$

These 'dream poems' also provided a balance to the more familiar and concrete tales of the Arthurian circle, as well as the work's more disturbing historical narratives such as "Concerning Geffray Teste Noire" or "Sir Peter Harpdon's End." Only a few of them, finally, are "unclear," in the sense that explanatory plot details are sparse. It may be possible to interpret the stories behind "The Wind," “The Blue Closet," "Golden Wings," "Near Avalon," and possibly "The Tune of Seven Towers" in more than one way, but their emo-

44. Tablet, April 1858, xix, 266.

45. Though noted in his day as a professor of classics at Oxford University, J. W. Mackail was also Professor of Poetry from 1906 to 1911 and had co-published two volumes of youthful verse: Mensae Secundae: Verses [in English] written in Balliol College, by H. C. Beeching, J. W. Mackail, and J. B. B. Nichols (Oxford, London: B. H. Blackwell, 1879), and Love In Idleness: A Volume of Poems, by H. C. Beeching, J. W. Mackail, and J. B. B. Nichols (London: Kegan Paul, 1883).

46. Mackail, Life, 1:133.

47. Silver, The Romance of William Morris, 40.

48. Elizabeth Helsinger, "Lyric Colour: Pre-Raphaelite Art and The Defence of Guenevere." Fiona MacCarthy has a less favorable view: "There is also a sequence of short dream poems, lugubrious Pre-Raphaelite scenes in which human figures huddle in unnerving mystic landscapes" (William Morris, 142). 
tional tone-deflecting any "irritable reaching after fact and reason"-was clear. $^{49}$

What then could Morris's reviewers have meant by their charges of lack of clarity? "Obscurity" for them might be translated as a heightening of selected details and suppression of others, creating mysterious and ominous frissons in which emotion took precedence over readily identifiable cause. The most extreme case of this pattern was probably "Near Avalon":

A ship with shields before the sun,

Six maidens round the mast,

A red-gold crown on every one,

A green gown on the last.

The fluttering green banners there

Are wrought with ladies' heads most fair,

And a portraiture of Guenevere

The middle of each sail doth bear.

A ship with sails before the wind,

And round the helm six knights,

Their heaumes are on, whereby, half blind,

They pass by many sights.

The tatter'd scarlet banners there,

Right soon will leave the spear-heads bare,

Those six knights sorrowfully bear

In all their heaumes some yellow hair.

Arthur's death in the poem is a passing emblem of the fate that befalls all who strive, and its near-imagist lines suggest (but do not assert) that oncevaliant knights (“Their heaumes are on, whereby, half blind”) have suffered an overwhelming defeat ("The tatter'd scarlet banners there"). The poem, in essence, is a striking, almost cinematic tableau that offers no narrative account of success or failure, only a memorial of defeated hopes and lost youth.

As for the work's 'roughness of language' decried by several reviewers ${ }^{50}$

49. John Keats identified "negative capability" in a letter to his brothers George and Thomas Keats, 21 December 1817.

50. Cf. Garnett, Literary Gazette, 6 March 1858, xlii, 227; the reviewer of the Tablet also noticed "a few bald lines and some which halt considerably" (April, 1858, 266). The Saturday Review critic complained that "The Defence of Guenevere" was written in "an ugly, disjointed 
in Guenevere and Launcelot's speech at Arthur's tomb, for example, or the soldiers' argument in "Sir Peter Harpdon's End"-several reviewers complained of discordant slant rhymes (a deliberate choice on Morris's part) and one, of his use of enjambment ${ }^{51}$ (surely no rarity after Keats, Shelley, and even Tennyson). Two reviewers reproved his use of "corn" and "dawn" as end rhymes in "Summer Dawn,"52 and he later replaced them in the Kelmscott edition ("They pray the long gloom through for daylight new-born," instead of the original "through the long twilight they pray for the dawn"-a rare example of Morrisian "worse-bettering").

In retrospect, it may be surprising that the most censorious of Morris's reviewers were not more successful than they were in discouraging the young poet. Anonymous reviews were a notoriously easy spectator sport, but The Defence's force and originality can almost be read through the lines of his most pettifogging reviews. His severest critics despised Browning's "obscurity" and the Pre-Raphaelite artists' vivid attention to detail, and were alert to punish any reappearance of cognate traits, skillful or inept. Though this was never articulated, they also seemed at times to contemn any poetry that rued violence, challenged established verities, confronted roseate views of British history, or contravened Victorian cults of success.

The Defence did also benefit from a fairly distinguished gathering of admirers. John Ruskin wrote the Brownings that Morris's newly issued poems "about old chivalry" were "most noble-very, very great indeed-in their own peculiar way." ${ }^{53}$ R. W. Dixon recalled that The Defence "drew great attention for the reason that it was so absolutely original, as well as on account of

series of unrhymed triplets" (November 1858, 507) and that the volume's final poems are "crabbed, and involved, and stiff, and broken-backed in metre" (507). Skelton noted that "Mr. Morris also is sometimes awkward" (Fraser's Magazine, 1860, vol. 61, 825), and the reviewer for the Ecclesiastic and Theologian objected to "the lack of rhythm, the barbarous rhymes, and the oftentimes bad grammar, which in so many places disfigure the verses" (March, 1858, vol. 20, 169).

51. As cited in the preceding note, the Ecclesiastic and Theologian critic objected to "barbarous rhymes" (169), and complained of "the almost invariable practice of never ending a sentence at the ordinary close of a stanza" (160). And as noted above, in the Literary Gazette Richard Garnett had reproved the poet's "frequent indifferent grammar, atrocious rhymes, and lines unscannable on any imaginable metrical system."

52. Garnett, Literary Gazette, March 1858, xlii, 426-27: “The barbarous rhyme, dawn and corn, is but a sample of that carelessness of which the author must get the better if he is ever to rank as a master of his art." The Ecclesiastic and Theologian critic singled out for censure "Guenevere" and "her" and "dawn" and "corn," the latter "twice repeated, an elegant but not an original cockneyism," as among "many other instances of a similar careless neglect" (March 1858 , vol. 20,169$)$.

53. March 1858, Works of John Ruskin, ed. Cook and Wedderburn (London: George Allen, 1903-12), 36:280. 
its merit." ${ }^{54}$ The Pre-Raphaelite sculptor and occasional poet Thomas Woolner wrote Emily Tennyson to ask whether she had "seen and do you like W. Morris' poems? . . . long ago he read me some which I thought contained some original ideas and an extraordinary power of entering the far-back old knightly way of looking at things." ${ }^{5}$ Rossetti praised Morris's "truth to the dramatic life of the old romance" in a July 1859 letter to Elizabeth Gaskell, and rated his Arthurian poems above Tennyson's newly published Idylls of the King. ${ }^{56}$ Most strikingly, William Michael Rossetti wrote of Morris in 1866 that "when he [is recognized properly] he will be acknowledged as by far the most genially and subtly chivalrous and medieval of all modern English poets.... A page of Morris is as rich as a painted window flooded with afternoon sun." ${ }^{7}$

Almost ten years later, Swinburne reviewed Morris's Life and Death of Jason for the June 1867 Fortnightly Review, and mounted a retrospective defense of the originality of The Defence of Guenevere:

Such things as were in this book are taught and learnt in no school but that of instinct. Upon no piece of work in the world was the impress of native character ever more distinctly stamped, more deeply branded. It needed no exceptional acuteness of ear or eye to see or hear that this poet held of none, stole from none, clung to none, as tenant, or as beggar, or as thief. Not as yet a master, he was assuredly no longer a pupil. . . .

But where among other and older poets of his time and country, is one comparable for perception and expression of tragic truth, of subtle and noble, terrible and piteous things? .. . The figures here given have the blood and breath, the shape and step of life; they can move and suffer; their repentance is as real as their desire; their shame lies as deep as their love. ... The retrospective vision of Launcelot and of Guenevere is as passionate and profound as life..$^{58}$

54. R. W. Dixon, "Memoir," 23.

55. February 1858, cited in Faulkner, William Morris: The Critical Heritage, 6.

56. 18 July 1859, The Correspondence of Dante Gabriel Rossetti, ed. William Fredeman (Woodbridge: Boydell and Brewer, 2008), vol. 1, letter 59.27, p. 263.

57. W. M. Rossetti, Swinburne's Poems and Ballads: A Criticism (London: John Hotton, 1866), 50.

58. Fortnightly Review, June 1867, viii, 19-28. Peter Faulkner cites an interesting latter-day commendation of these early poems by H. M. Hyndman, Morris's sometime-comrade and bête noire in the Social Democratic Federation: "It shows how little was known of William Morris by the ordinary man who was deeply interested in literature, that it was not before 1865 that I became acquainted with his writings ... Morris was easily intelligible, the charm of his verse is attractive to all, and ... yet it was not until Swinburne spoke of him as a great poet 
In reviews such as these, the rehabilitation of Morris's early volume was effectively underway, and it continued in an 1867 review by Joseph Knight which appeared prominently in the Sunday Times:

Very singular has been the fate of Mr. Morris' early work. As regards the public it was a failure so complete that its author, if unsupported by self-knowledge and the promptings of genius, might well have retired in discouragement from the strife for fame. With a select few, however, comprising men of highest culture and those whose opinions upon poetry have most weight, it speedily became a remarkable favourite. Such a volumeso thoroughly imbued with antique spirit, so full of wonderful colour, so strange, mystical, and unearthly, yet withal so profoundly poetical-had seldom before been seen, and at its first appearance stamped its author a man of highest mark. . . . To the man who can write such poems as 'The Chapel in Lyoness,' 'Rapunzel,' 'Shameful Death,' or 'The Haystack in the Floods,' a mine of wealth is open which none but he can explore..$^{59}$

Even more influential were the assessments in the famous 1868 review of The Earthly Paradise by Walter Pater, who found in The Defence a reenactment of the most profound tensions of medieval history:

The Defence of Guenevere: and Other Poems, published ten years ago, are a refinement upon this later, profounder medievalism [which recreates the mind of the middle age]. The poem which gives its name to the volume is a thing tormented and awry with passion, like the body of Guenevere defending herself from the charge of adultery, and the accent falls in strange, unwonted places with the effect of a great cry. . . . What is characteristic in [these Arthurian legends] is the strange suggestion of a deliberate choice between Christ and a rival lover... .

A passion of which the outlets are sealed, begets a tension of nerve, in which the sensible world comes to one with a reinforced brilliance and relief-all redness is turned into blood, all water into tears. Hence a wild,

that the majority even of reading men were aware that so fine a genius was living unappreciated among us" (Record of an Adventurous Life [London: Macmillan, 1911], chap. 21). Faulkner also cites the art critic J. Comyns Carr, who recalled that "my imagination had been deeply stirred by the first volume of Mr. Morris' verse. . . . I found here . . . that deeper note of passion which Tennyson's poetry, even at its best, confessedly lacks. . . Morris at a single stroke seemed to restore the legend to its historical place, and to recapture a part of its passionate significance" (Some Eminent Victorians: Personal Recollections in the World of Art and Letters [London: Duckworth, 1908], 14).

59. Joseph Knight, Sunday Times, 9 June 1867, no. 2304, 7. 
convulsed sensuousness in the poetry of the middle age, in which the things of nature begin to play a strange delirious part. ${ }^{60}$

All this was very well, but May Morris remembered her father's special gratitude for the sympathetic early reviews of Garnett, Skelton, and an unidentified critic who may have been the reviewer for the Tablet:

Two figures, well known in London, stand out in the crowd, friendly and genial. They were the first critics to "discover" the new poet; my mother remembers how my father came to her one day in a great state of excitement, waving the paper containing the notice of "The Defence of Guenevere," and the excitement was no less over Dr Richard Garnett's cordial and discriminating review of the poems ... [and the review] [t]hat thoughtful critic "Shirley" wrote on "Guenevere" a little later. ${ }^{61}$

I have often heard my father speak with warm appreciation of the kindly treatment he received at the hands of these two men. I do not think the feeling of affectionate gratitude he had towards them in consequence ever weakened throughout his life. It is not a little thing for a shy and sensitive young man to have his first volume of poems treated with understanding and sympathy. ${ }^{62}$

\section{XPERIMENTATION AFTER THE DEFENCE}

Morris's friends and a few thoughtful critics had stood by him, but it would be insensitive to suppose that someone who had explored the implications of failure throughout his poems would take lightly the near-universal condescension visited on his first published work. He did not complain, but his daughter May reported that "My father was not willing to have 'Guenevere' republished, but was finally persuaded by Mr. Ellis to issue an 1875 reprint." ${ }^{33}$ The moderately critical reviewer for the Tablet had perceptively observed that

the poet has this right, that, in consideration of the gift of poetry that he has received, ... we must simply accept him as he essentially is, and forbear

\footnotetext{
6o. Westminster Review, xc, October 1868, 302.

61. May Morris, ed., CW, 1:xxi.

62. Ibid.

63. Ibid., xxv.
} 
from requiring him to be something wholly different. We may ... point out faults and blemishes, the absence of which would be desirable. But our objections must not go to the very root and being of his nature and inspiration, for, had such objections prevailed, we should have been without his poem. $^{64}$

In the next decade Morris threw himself into efforts to experiment with new crafts-stained glass, tile-work, woodblock and wallpaper design, and illumination of manuscripts-but he did not abandon poetry, despite the demands of his 'day job' at Morris and Co. and the birth of his two young children.

Morris's harshest critics had focused on the alleged failings in The Defence outlined above-its 'historicism,' its 'obscurity' (construed as the paucity of connectives), and its excessive ambiguity, introspection, and emotional 'extravagance.' They had also attacked Morris's independence, focusing especially on his affinities with Rossetti and Browning, charges for which he henceforth strove to give no occasion. It is possible that under other circumstances Morris might have further developed the dramatic forms for which he had a natural bent, ${ }^{65}$ but the academic and theological disputes that characterized Browning's later work had little attraction for him ("Of heaven and hell I have no power to sing").

The historicism mentioned above was embedded into his sensibility and nonnegotiable. But what if he enlarged the canvas of these collective memories, embedded his characters' reveries into tales narrated by thoughtful survivors of the Black Death, and infused their tales with the empathy and wistful regrets of good people for whom youth was a fond memory? Morris loved intricate tapestries and older literary forms. Could he not honor those forms and designs in intricate tapestries of historically informed verse?

It wasn't quite that simple, of course. Morris had originally planned a poetic sequence centered on the fellowship of the Round Table, and had written partial drafts of "The Maying of Queen Guenevere," "Sir Palomydes' Quest," "St. Agnes's Convent," and "St. George," as well as the four Malorian poems published in the Defence, but set these plans aside when Tennyson published the first segment of the Idylls in 1859. Mackail expressed regret for this decision:

64. Tablet, April 1858, xix, 266.

65. Pamela Bracken Wiens, "The Empathetic Vision of William Morris." See also The Tables Turned, or Nupkins Awakened: A Socialist Interlude, ed. Pamela Bracken Wiens (Athens: Ohio University Press, 1994). Ironically, Browning had responded to early hostile reviews by adopting the distanced, oblique frames for which Morris was now criticized. 
The mixed lyric and dramatic method which he had invented for "Sir Peter Harpdon's End," with its odd and fascinating use of blank verse, had in it all kinds of possibilities. He had already planned ... an Arthurian cycle ... in which, it has been thought, he would have found his most real inspiration. . . A After [the 1859 publication of the first segment of the Idylls of the King] the treatment of the story in a different, even if a simpler and sincerer manner, was almost precluded by the imposing brilliance of the Tennysonian version. ${ }^{66}$

And in a further attempt, perhaps, to avoid charges of imitation, Morris had also begun a series of sonnets to his wife which were discontinued as Rossetti progressed with "The House of Life."

A more important motivation for his shift in style, however, was Morris's own commitment to directness and clarity of expression. In his Oxford and Cambridge Magazine review of Men and Women, Morris had justified Browning's alleged 'obscurity' - anticipating postmodern reader response criticism: "we must not think it hard if we have sometimes to exercise thought over a great poem, nay, even sometimes ... an agony almost equal to that of the poet who created the poem." ${ }^{67}$ Perhaps this was a form of special pleading; in any case, after the Defence Morris's writings exhibit greater directness and narrative clarity.

In addition to "Scenes from the Fall of Troy," then in progress, he seems to have begun several dramatic fragments, including what may have been an early draft for "Love Is Enough," the uncompleted poetic dramas "In Arthur's House" and "Anthony," and several drafts and experiments with antiphonal dialogue. His later prose romances and even his one-act political satire The Tables Turned or, Nupkins Awakened drew on skills he honed in this period.

As he worked at his 'night job(s)' in the aftermath of the Defence, Morris may also have decided to offer potential readers an "agony almost equal to that of the poet" at a conceptual and narrative remove. He had a natural gift for direct expression of his thoughts as "a man speaking to men" [sic], a trait his admirer Burne-Jones characterized in another context as follows:

I suppose if he'd painted he would never have hidden things with darkness. That was Top, so clear. That was Top, so out in the sunlight. Never wanted to snatch at anything. ${ }^{68}$

66. Mackail, Life, 1:134.

67. Oxford and Cambridge Magazine, March 1856, 172.

68. 7 January 1898, Burne-Jones Talking, ed. Mary Lago (Columbia: University of Missouri Press, 1981), 168. 
Morris's final drafts for the best Earthly Paradise tales were "obscure" in their sources, their archaisms, their allusions to classical and medieval ways of life, and their interludes of reflective, almost eschatological melancholy. But his narratives read swiftly, and he strove to make their images more visible "in the sunlight." As a middle-aged socialist, he regarded clarity as an imperative in "The Pilgrims of Hope," his "Chants for Socialists," and his fervent but plainspoken artistic and political essays. The first public sign of this gradual shift appeared in his independently published proto-Earthly Paradise tale The Life and Death of Jason, characterized by its Sunday Times reviewer as "musical, clear, and flowing, strangely imaginative and suggestive, presenting pictures of almost incomparable beauty," and by Swinburne in the Fortnightly Review as "a poem sown of itself, sprung from no alien seed, cut after no alien model; fresh as wind, bright as light, full of the spring and the sun." ${ }^{\circ 9}$

Even so, Morris's later work continued to "flinch from modern varnish."70 Almost all of his Earthly Paradise tales drew on quasi-mythical historical and geographical settings-medieval middle-European ("The Hill of Venus"), Scandinavian (“The Lovers of Gudrun"), Near Eastern (“The Man Who Never Laughed Again"), and classical ("The Story of Cupid and Psyche")—none of which were to be found in the British Isles. ${ }^{71}$ Many of them, moreover"Ogier the Dane," "The Hill of Venus," and Love Is Enough, for example-were inset allusive dream narratives in folktale guise, and others more exactly situated in time and space-the Icelandic saga-account of "The Lovers of Gudrun," among others-embedded their realistically erotic and psychological plots in intermundia of myth and prophecy.

Morris also buffered his genuinely erudite narratives in The Earthly Paradise with internal narrators, narrative interludes, and transitional lyrics, continued the Defence's vivid coloration in the word-painting of the tales, and transposed his introspective dramatic monologues into 'internal' Earthly Paradise characters such as Bodli, Psyche, Stenoboea, and Philonoë. He also wrote interspersed songs and ballads, such as the nymph's song "I know a little garden-close" in the fourth book of Jason and "Outlanders, whence come ye last" in "The Land East of the Sun and West of the Moon." The Defence's uncertainties and ambiguities migrated into the principal tales' echeloned 'internal' frames and the collective responsiones of their poets, singers, and 'external' storytellers. Certain 'internal' voices-that of Orpheus in Jason, for

69. Knight, Sunday Times, 9 June 1867, no. 2304, 7; Swinburne, Fortnightly Review, July 1867, viii, rpr. Essays and Studies (London: Chatto and Windus, 1875), 117.

70. Elizabeth Barrett Browning, Aurora Leigh, bk. 5, 1. 280.

71. In a rare exception, the hero of "The Land East of the Sun and West of the Moon" travels briefly to St. Albans, though he had begun life in Norway. The Earthly Paradise by William Morris, ed. Florence Boos, 2:100, 1. 2439. 
example, and the "singer" of The Earthly Paradise-merged into the poet's own, and offered antiphonal metacommentaries as the tales' 'internal' choirs.

None of this could entirely purge the internalized frustration Morris felt at the more obtuse critics' dismissals. Dixon recalled with regret Morris's "massacre" of a sheaf of poems, some of which may have been written after The Defence ("It was a dreadful mistake to destroy them"72); and May Morris thought it "probable, considering that his style altered after the appearance of that first slim book, that we have lost poems of a fine intense quality, much undervalued by the impetuous author." ${ }^{3}$

It is therefore not possible to say with certainty that Morris took greater care than previously as he prepared his next volume. What is certain is that he experimented with a range of poetic forms-drama, lyric, and longer narrative-and prepared several versions of each in the years after The Defence appeared. May Morris described his practice later as follows:

It is characteristic of my father's way of working that he should re-model a poem, sometimes on entirely different lines and in a different measure, discarding pages and pages of matter. ... Correcting meant for him, more often than not, re-writing. ${ }^{74}$

Whatever was destroyed and whatever its quality, it is also clear at least that Morris did not turn away from poetry in the years between 1858 and 1867 . His experiments in this period took four main directions-toward drama, sonnets, short lyrics, and blank verse. Consideration of these new ventures follows.

\section{RAMA: "SCENES FROM THE FALL OF TROY"}

Morris began the manuscript of "Scenes from the Fall of Troy"75 when he was still at Oxford, for Dixon recalled that Morris told him in 1856 or 1857

72. R. W. Dixon, "Memoir," 21: "Shortly after he had published his first volume, he told me in London that he had 'massacred' all those early poems; giving the reason that they had in them so much of 'the absurd."”

73. $C W, 1: x v$; "Early Poems," http://morrisedition.lib.uiowa.edu/earlypoems.html.

74. $C W, 1: x x i$.

75. Published in CW, 24:3-51. Draft in B. L. Add. MS 45,321, ff. i +65 , some written out fairly well, some in messy draft, some in penciled outline. A part of this MS was copied by Murray and another part by Emma Morris, and these would most likely have been composed early. Also in B. L. MS 45,298A there are 2 pp. of the opening verses copied in Morris's fair hand, followed by a page of a rejected draft in couplets, perhaps an attempt at an introduction. Fitz. MS 3, f. 27 is a one-page fragment on Paris and Helen in Morris's handwriting, containing as Helen's song, the lyric "Ah how lone how lone it is," and about twenty lines of narrative couplets. 
that he had written some "blazing blank verse": and [he] read me a long piece in blank verse. It was a monologue spoken by Helen of Troy: and, as he read it, certainly seemed to answer his description of it. ${ }^{76}$

J. W. Mackail and May Morris also confirmed that Morris had planned a Troy cycle for some time, ${ }^{77}$ and the passage he read to Dixon could well have been Helen's opening words to Paris in the manuscript's first section, "Helen Arming Paris."

David Latham has established that the first surviving manuscript was watermarked in $1856,{ }^{78}$ and May claimed that "Scenes" was "partly written as early as 1857 or $58 .{ }^{\prime 79}$ The extant finished sections had a unity of tone and theme, but May Morris a found list of potential "scenes" in a notebook dated $1862,{ }^{80}$ which suggested that the work was still in progress, and in William Morris: Artist, Writer, Socialist she listed the year when "the Troy poem [was] being written" as $1865 .{ }^{81}$

The preserved 'fragment' was also rather extensive. Five sections out of the twelve in Morris's outline were missing - "Hector brought dead to Troy," "The wedding of Polyxena," "The last fight before Troy," "The Wooden Horse," and "Aeneas on shipboard"-but he had already completed the central romantic passages and ensuing scenes in which Menelaus broke into Helen's bedroom, demanded she collude in the murder of Deiphobus, and prepared to carry her back as a trophy to Greece. In the end the work's unrelenting grief may have stayed Morris's hand, for he returned to its setting only once more, in "The Death of Paris" in The Earthly Paradise.

Be that as it may, certain aspects of "Scenes" broadly paralleled counterparts in "Sir Peter Harpdon's End" and "The Haystack in the Floods." In the first, for example, the besieged Peter had told his foe Lambert that he identified with the Trojans:

Yea, they fought well ...

almost all men, reading that sad siege,

76. Dixon, “Memoir," 21.

77. Mackail, Life, 1:134: "He had already planned, and begun to write, a cycle of poems in this form on subjects from the war of Troy." May Morris discusses the Troy cycle in the introduction to $C W, 24: x x v i i-x x v i i i$.

78. Latham, introduction to "The Wanderers," "Unpublished Tales from the Earthly Paradise," William Morris Archive, http://morrisedition.lib.uiowa.edu/epwanderersintro.html.

79. $C W, 2$ :xiv.

8o. In her introduction to $C W$, vol. 2, May Morris describes an 1862 notebook containing a list of subjects for "Scenes from the Fall of Troy," and she repeats this date in AWS, 1:392: "And then in . . . an 1862 notebook of great and varied interest, we come upon a list of some of the scenes of the Troy poem, showing that he was still at work upon it."

81. AWS, 2:633. 
Hold for the Trojans; as I did at least,

Thought Hector the best knight a long way. ... (11. 202, 206-8)

And in "The Haystack in the Floods," Jehane's anticipation of her future as Godmar's captive resembled Helen's premonition of what her fate would be when captured:

We shall come at last

To land in Greece, and all shall cry at me,

"See her who slew the sons of Priamus,

Who threw to earth that right fair town of Troy,

Who slew full many a mother's son of Greece! ...

Is there no faggot for her false white limbs?" (I, 11. 26-30, 32)

As written, Morris's first poetic cycle was an eclectic and rather erudite compilation of several antecedents-Homer's Iliad, of course, but also Virgil's Aeneid, Chaucer's Troilus and Creseyde, Shakespeare's Troilus and Cressida, and passages from Walter Landor's 1847 Hellenics and William Caxton's Recuyell of the Historyes of Troy ${ }^{83}$ - which was nonetheless completely untainted by The Defence's "obscurity." Morris's cycle adopted aspects of the Troy-centered view shared by many medieval writers, though not necessarily their motives for it, ${ }^{84}$ and like them, focused the narrative on Menelaus's brutality, the unchivalrous killing of Hector by Achilles, and Paris's murder of Achilles at the latter's marriage to Priam's daughter Polyxena. ${ }^{85} \mathrm{He}$ also cast his fragment as a 'defence' of the Guenevere-like Helen against literary charges brought against her by Walter Savage Landor, among others, ${ }^{86}$ and his youthful pride in Helen's soliloquy was borne out by the quality of the manuscript's writing as well as its somewhat novel form. ${ }^{87}$

82. CW, 24:3-51, and http://morrisedition.lib.uiowa.edu/earlypoemslistandtexts.html.

83. Peter Wright, "William Morris's 'Scenes from the Fall of Troy," http://morrisedition.lib.uiowa.edu/earlypoemstroywright.html. Wright notes that Landor had treated "The Wedding of Polyxena," the topic of one of Morris's projected scenes, and "Menelaus and Helen of Troy," which parallels his last completed scene. Here again, Landor's Helen is more culpable and his Menelaus less brutal. Achilles's slaying of the unarmed Hector is present in Shakespeare's version, and the attack on Achilles by Menon appears in Caxton, as does Achilles's offer to Queen Hecuba to end the siege in return for her daughter's hand. The scene in which Menelaus and Helen slay Deiphobus derives from book 6 of the Aeneid, though Virgil makes her a willing accomplice.

84. As Peter Wright has observed, "many medieval peoples were proud to claim [a] similar mythical Trojan descent" ("William Morris's 'Scenes from the Fall of Troy").

85. Ibid.

86. Ibid.

87. Peter Wright has observed that most nineteenth-century poets wrote five-act verse 
As in "Sir Peter Harpdon's End," Morris 'began' the drama near its close and employed flashbacks and retrospective explanations to clarify the course of its events. As part of Helen's self-vindication, for example, she recalled affectionately her elopement with Paris:

My poor kind knight ...

Who taught me how to live, when long ago

I had forgotten that the world was fair

And I was fair: who made my lying down

Right peaceful to my tired heart and limbs, ...

Who gave me joyful hours day by day. ("Helen Arming Paris," I, 11. 58, $61-62,64,66)^{88}$

Ironies abound, as when Helen celebrates the apparent departure of the Greeks:

I would I could remember, but for me

It shall be always so, and like a dream ...

and when music sounds

I may remember of these other days

And think of Paris for a little while....

Paris my love is dead

And I feel waked to live another life. ("Helen and Menelaus," 11. 51-52, $60-62,65-66)$

The extant sections are also intercut with songs and ballads, some of which are markedly ironic or prophetic-Helen's two "arming songs" to Paris, for example:

Trouble must be kept afar

Therefore go I to the war; ...

Kiss me sweet, for who knoweth

What thing cometh after death. ("Helen's Chamber," second version, 11. 97-98, 103-104)

dramas that could in principle be staged (ibid.). Examples include Shelley's The Cenci and Browning's Strafford; exceptions include Byron's Manfred (3 acts) and Arnold's Empedocles on Etna (2 acts).

88. Line numbers are from the William Morris Archive, http://morrisedition.lib.uiowa. edu/earlypoemsscenestext.html. 
When Paris later asks his mother Hecuba to sing to him, she responds with a quasi-medieval lament of her life's cycle, from royalty to servitude: ${ }^{89}$

Seen by the stars, I shone out bright:

Many a slave was mine of right.

Ah but in the days of old

The Sea Kings were waxen bold,

In their long-ship they carried me

And set me down by a strange sea:

None of the Gods remembered me. ...

I draw water from the well,

I bind wood that the men fell:

Whoso willeth smiteth me,

An old woman by the sea. (“Achilles' Love Letter," 11. 83-87, 96-99)

He also made quasi-balladic use of patterned repetition, as in Hecuba's recollection of Paris's youth:

Ah times are changed: the merry days are gone

When 'twixt the east wind and the cold bright sun

You grew a stout youth on the mountain tops.

Ah times are changed. . . . (“Achilles' Love Letter," 11. 62-65)

Stark images convey inner states and premonitions, as in Paris's depression after the death of Hector:

Mother, I say we have slipped down to hell

Not knowing it; yea each man in his place,

Houses and cattle, slaves and goods and all,

Greeks, leaguers, all have fallen into hell

Unwitting- (“Achilles' Love Letter," 11. 42-46)

When Helen asks Paris before his last conflict whether "heavy dreams" oppress him, he replies:

89. Compare medieval laments by women speakers, such as "The Hag of Beare," and "Gormley's Lament": "I have loved thirty by three ..." (Penguin Book of Women Poets, ed. Carol Cosman, Joan Keefe, and Kathleen Weaver [New York: Viking, 1979]). 
Yea, like some man am I that lies and dreams

That he is dead, and turning round to wake

Is slain at once without a cry for help. ("Helen's Chamber," second version,

11. 21-23)

There is no hope or recourse after Menelaus's crude atrocities, and Helen laments the sordid and indiscriminate violence of war. Even the Greeks suffer:

They are become mine enemies, yet still

I am half grieved for their unspoken woes, ...

They know themselves to be but ruined men

Whatever happens-... (“Helen Arming Paris," 11. 140-41, 143-44)

Even Priam ponders for a moment the predicament of his enemies:

The houses they all loved, far off in Greece,

Are painted fresh by men they knew not of; ... .

The ancient boundaries of their lands are changed. ("The Defiance of the Greeks," 11. 29-30, 37)

Most starkly (and appropriately) portrayed are the slaughtered innocents of every war:

... bones of women that looked out at me

Calling out "Helen!"- -bones of young children

Born in the siege who never knew of peace. ... ("Helen Arming Paris," 11.

79-81)

Priam's and others' forebodings are realized in his brutal stabbing and the abduction of his daughter Cassandra, and Paris neatly summarizes the facts of the matter to his mother: "Now all has come to stabbing in the dark" ("Achilles' Love Letter," 1. 152).

The unfinished "Scenes from the Fall of Troy" was excellent of its kind, and Morris's decision to leave it in the drawer remains a puzzle. Perhaps its blunt critiques of war for imperial acquisition aroused hostility, or perhaps he simply decided the poem had become too long to serve as a separate tale in his new cycle (a fate that later befell "The Wanderers"). Or perhaps he simply set it aside in favor of the Chaucerian/Boccaccian design of The Earthly Paradise in its final form. He did later return to dramatic forms in his distinctively introspective masque Love Is Enough (1873). "Scenes" was clearly too long to 
include in his 1891 collection of occasional Poems by the Way, but it finally found its way between hard covers in his Collected Works.

\section{$\oint_{\text {ERsonal sonnets And LYRICS }}$}

One of the many polarities of Morris's life was his joint commitment to privacy and transparency - the latter reflected in his poetic narratives, and the former in his personal lyrics of the late 1860s and '70s. The lyrics came as near to "unmediated" poetic speech as anything he wrote, and many of them remained unpublished in his lifetime. Chronology would otherwise dictate that an extended examination of his personal poems appear elsewhere, ${ }^{90}$ but some of his sonnets mark or reflect the new direction of his work after The Defence.

Most of the three dozen poems in this category were written between 1869 and 1873, and seven were sonnets. All of the latter were essentially Petrarchan-another effort to put medieval forms to contemporary use-but none of them found a place in Poems by the Way or the "Book of Verse" he illuminated as a gift to Georgiana Burne-Jones. Three of the seven did appear in contemporary periodicals: "Hapless Love" and "Sad-Eyed and Soft and Grey" appeared in Good Words for April 1869, and "Rhyme Slayeth Shame" and "May Grown A-Cold" in the Atlantic Monthly for February and March 1870. May included only one of these sonnets in the final volume of the Collected Works, and two in her 1936 Artist, Writer, Socialist. ${ }^{11}$

90. For a list of Morris's poems, published and in draft, see "Morris's Early Poems" and "Poems of the Earthly Paradise Period," William Morris Archive, http://morrisedition.lib. uiowa.edu/listpoems.html. Criteria would differ for the category of personal lyric, but of my list of forty-one, twenty were never published in any form during his lifetime, and another ten published in periodicals or included in "A Book of Verse" failed to appear in book form during his lifetime. After Morris's death, May Morris published another eleven of these uncollected poems in $C W$, vol. 24, including the four that Morris had already issued in periodicals, one poem that had appeared in "A Book of Verse," and six additional poems, among them the sonnet "As This Thin Thread." In AWS, vol. 1, she included two more sonnets, "The Doomed Ship" and "Near But Far Away." Of his seven sonnets from this period, William Morris published three and his daughter three more.

91. B. L. MS. 45,298A, f. 115, published Good Words, April 1869, then edited by the reforming Scottish clergyman Norman Macleod. "Dear If God Praise Thee Much for Many a Thing," one of the earliest, was also unfinished. An interesting manuscript in the British Library, Add. Ms. 45,298B, consists of a notebook in which Jane Morris copied several of her husband's poems by hand, and five of these sonnets are among those copied. The two not copied are "May Grown A-Cold," published in the Atlantic Monthly, and "Near But Far Away." 


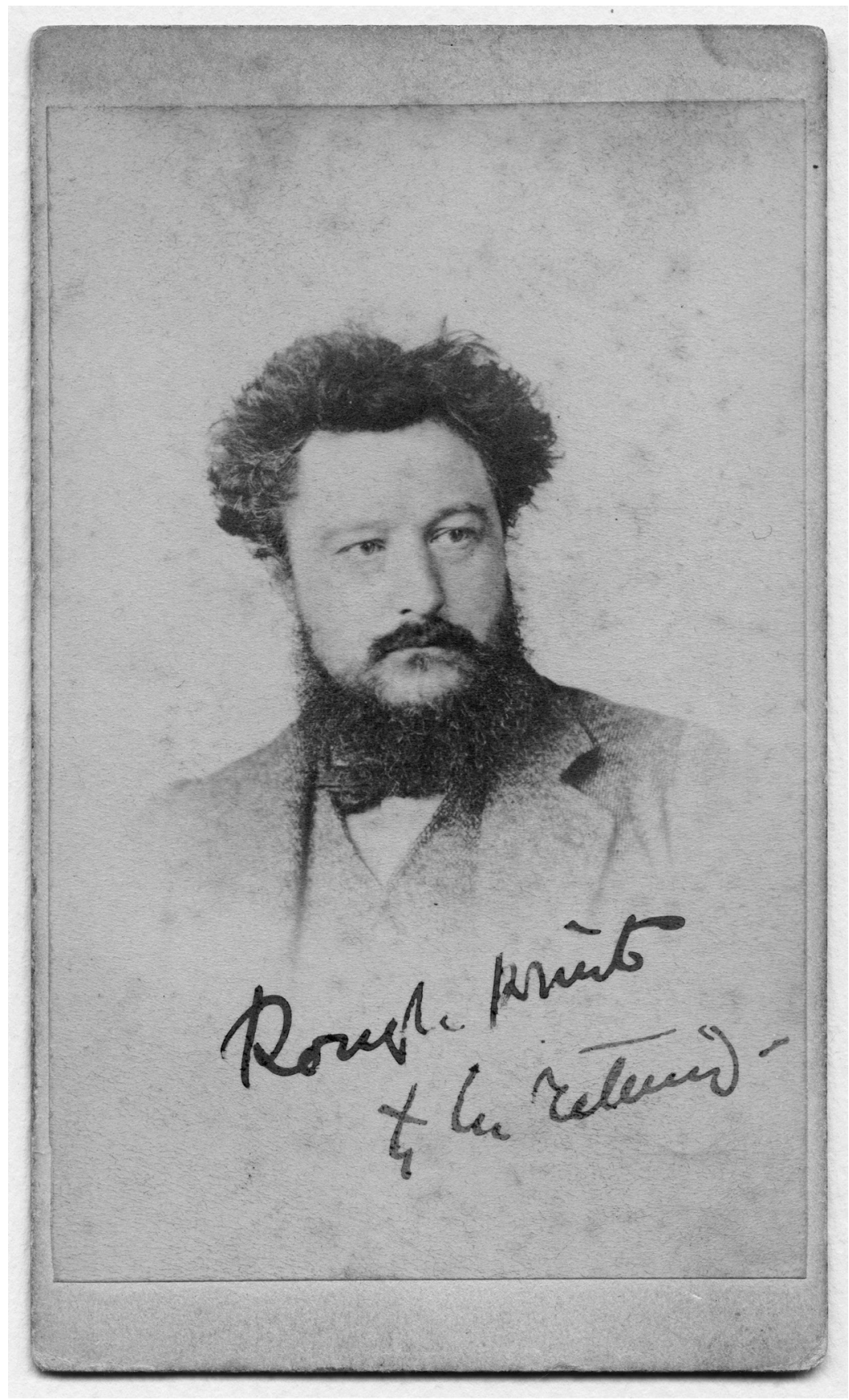

FIGURE 19. William Morris in 1870, carte de visite. Courtesy of the National Portrait Gallery. 
May Morris believed that "Sad-Eyed and Soft and Grey" was the first written of these few published sonnets..$^{92}$ Its landscape, dreamlike qualities, and allegory of the loss of love resembled cognate qualities in The Earthly Paradise's monthly lyrics:

Sad-eyed and soft and grey thou art O morn!

Across the long grass of the marshy plain

Thy west wind whispers of the coming grain

The lark forgets that day is grown forlorn

Above the lush blades of the springing corn,

Thy thrush within the high elm strives in vain

To store up tales of spring for summer's pain-

Vain day, why wert thou from the dark night born?

O many-voiced strange morn, why must thou break

With vain desire the softness of my dream

Where she and I alone on earth did seem?

How hadst thou heart from me that land to take

Wherein she wandered softly for my sake

And I and she no harm of love might deem?

By implication, the "land . . . wherein she wandered softly for my sake" has been illusory, but not an illusion lightly to be relinquished, for in it may be heard the dawn sounds of wind, thrush, and lark.

Rossetti composed seventeen "House of Life" sonnets before $1867,{ }^{93}$ and two of Morris's extant sonnets resemble Rossetti's in their development of a central conflict or metaphor. The central conceit of "The Doomed Ship" parallels that of Rossetti's 1854 "Lost on Both Sides," (sonnet 91 of "The House of Life"), in which two men "who have loved a woman well, / Each hating each, through Love and Death's deceit," form a duality which is unconvincingly compared to the "separate hopes, which in a soul had wooed, / The one same Peace, [and] strove with each other long." But in Morris's sonnet the central metaphor is a rudderless ship:

92. Morris's manuscripts were of course arranged after his death, and seem to be placed in roughly chronological order as this was understood by his daughter and executors. If May Morris's comment that "Sad-Eyed and Soft" precedes "Rhyme Slayeth Shame" and "May Grown A-Cold" is correct, however, this sonnet is somewhat out of order.

93. William E. Fredeman, "In Memoriam: An Elegiac Reading of 'The House of Life," Bulletin of the John Rylands Library 47 (1965), 335-40. 
The doomed ship drives on helpless through the sea,

All that the mariners may do is done,

And death is left for men to gaze upon,

While side by side two friends sit silently;

Friends once, foes once, and now by death made free

Of Love and Hate, of all things lost or won;

Yet still the wonder of that strife bygone

Clouds all the hope or horror that may be.

Thus, Sorrow, are we sitting side by side

Amid this welter of the grey despair,

Nor have we images of foul or fair

To vex save of thy kissed face of a bride,

Thy scornful face of tears when I was tried,

And failed neath pain I was not made to bear[.] $]^{94}$

Biographically, of course, the images of "The Doomed Ship" make unfortunate sense in the context of Rossetti's sexual interest in Morris's wife, so it is not surprising that this sonnet remained unpublished until 1936, but it also retains a measure of interest in its use of extended similes associated with the Petrarchan sonnet.

In "As This Thin Thread," Morris's other sonnet focused on a single extended metaphor, a "little thread" given by the speaker is externally accepted but inwardly rejected.

As this thin thread upon thy neck shall lie

So on thy heart let my poor love abide,

Not noted much and yet not cast aside

Since it may be that fear and mockery

And shame, earth's tyrants, the thin thing shall try

Nor burn away what little worth may hide

Within its pettiness, till fully tried

Time leaves it as a thing that will not die.

Then hearken! Thou, who forgest day by day

No chain for me, but arms I needs must wear,

94. B. L. Add. MS. 45,298A, f. 88 . This version is the first of two in manuscript draft, and May Morris printed it in AWS, 1:539. See the William Morris Archive, http://morrisedition.lib. uiowa.edu/listpoemsepperiodcontents.html\#A-3. 


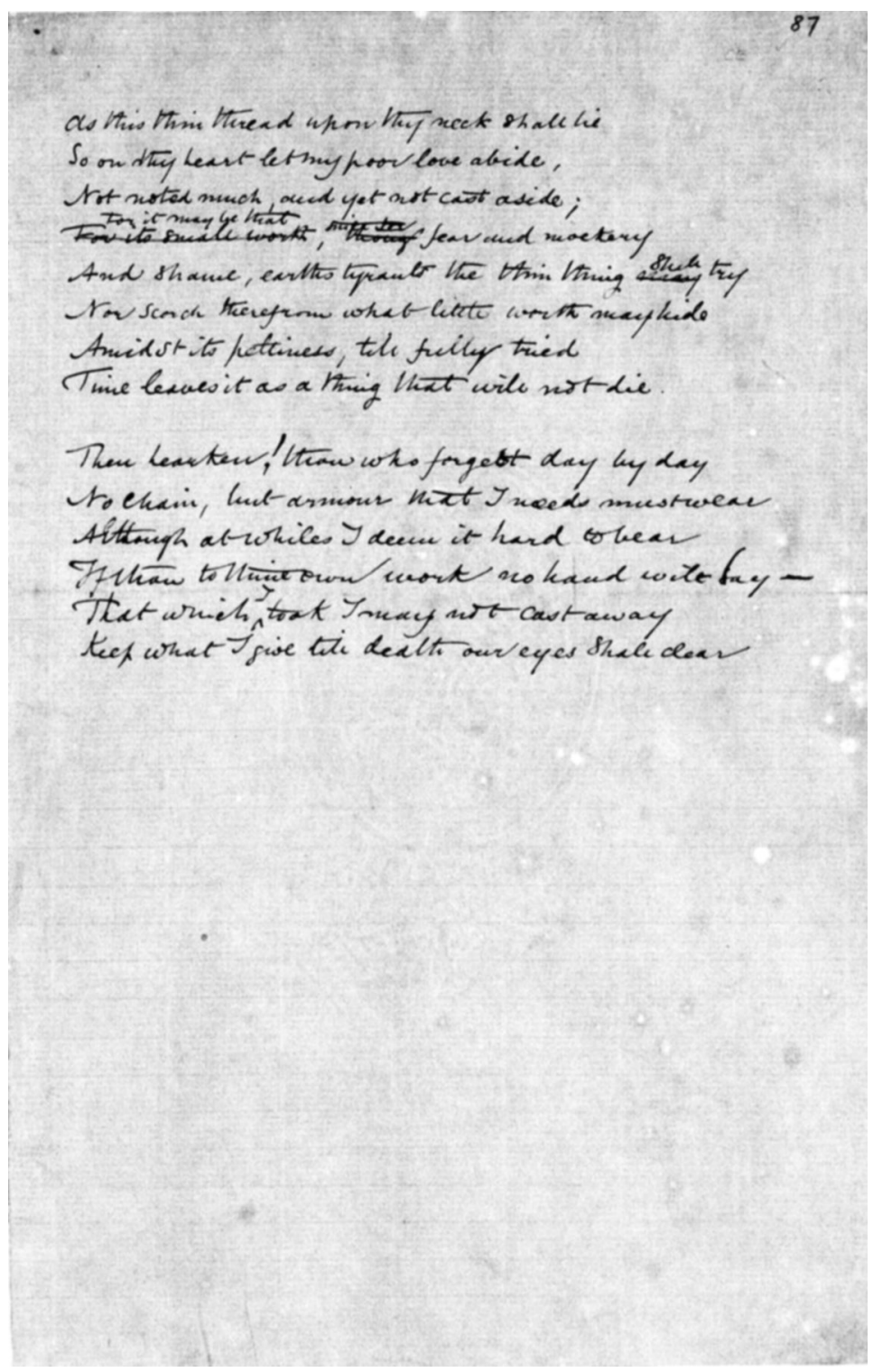

FIGURE 20. "As This Thin Thread," B. L. MS. 45, 298A, f. 87. Image courtesy of the British Library. 
Although at whiles I deem them hard to bear,

If thou to thine own work no hand will lay-

That which I too I may not cast away,

Keep what I give till death our eyes shall clear.

The fragility of the "thread" reflects its susceptibility to "fear," "mockery," and "shame," but as a "chain" (presumably of gold or silver) it remains a "thing that will not die." The speaker accepts sadly that he must bear the burden for both himself and his loved one ("If thou to thine own work no hand will lay"), and only pleads with her to "keep what I give till death our eyes shall clear." It may be no accident that four manuscript drafts of this sonnet remain, as well as a fair autograph copy. ${ }^{95}$

Rossetti wrote brilliant sonnets that were image-laden and self-consciously 'universal' ("A sonnet is a moment's monument"). Morris, by contrast, addressed these two sonnets and other short poems of the period directly and intimately to a single, specific recipient, an intention that marked their uniqueness and explained why he never replicated them: he had said what he wished to say, and the rest was silence.

All Morris's sonnets of this period expressed loneliness or estrangement in the language of traditional love gallantries. ${ }^{96}$ It is possible that he intended them to form a sequence, perhaps with an ending celebrating a hoped-for return of love. As Rossetti moved toward the completion of his own sequence Morris soon turned to other modes, perhaps in part to avoid the charge of imitation, and shifted to stanza-forms that permitted a wider range and greater spontaneity of expression for the lyrics of The Earthly Paradise. ${ }^{97}$ Once Morris had decided on the more open form he would employ in its

95. Untitled, B. L. Add. Ms. 45,298A, ff. 87-87v, Morris autograph on blue ruled paper; 4 drafts, none an uncorrected fair copy. In the last line "death" is uncapitalized. Also a fair autograph copy is in WMG J153. May Morris published it in CW, 24:359.

96. In "Rhyme Slayeth Shame," the speaker asks his poem to tell his loved one "That love has slain time, and knows no today / And no tomorrow," and "May Grown A-Cold" anticipates the monthly lyrics of The Earthly Paradise in its contrast between the season's beauty and the speaker's loneliness. The most personal of these sonnets is "Near But Far Away," in which the object of the speaker's love cries "Brother!", kisses him, and then swiftly departs, leaving the speaker to mourn. This has evoked biographical speculation that it records an alleged encounter between Morris and Georgiana Burne-Jones, or more fancifully, between Morris and his actual sister Emma (then a clergyman's wife living in northern England). Fortunately, it is not necessary to hold a fixed opinion on the occasion of each sonnet in order to interpret their general patterns.

97. These included his other personal lyrics of the period-“Summer Night," "Rest from Seeking," "Love Fulfilled," "Error and Loss," "Hope Dieth, Love Liveth," "From the Upland to the Sea," and "Thunder in the Garden" as well as a pair of monthly lyrics for The Earthly Paradise that remained in manuscript. The latter were printed by May Morris in $C W, 6: x x v i i$. 
monthly lyrics - three seven-line stanzas for length and balance-he never again returned to the sonnet, with the exception of two poems composed for his 1869 translation of the Icelandic saga "Grettir the Strong."

\section{"T He WAnderers"}

Long before the appearance of The Earthly Paradise in 1868, Morris conceived the idea for a long poem with many subordinate parts, and began work on a prologue which would provide its frame. May Morris claims that "The Prologue of 'The Earthly Paradise' gave my father more trouble than all the rest of the work," of Venus" in The Earthly Paradise went through ten drafts. ${ }^{100}$

According to David Latham, the modern editor of "The Wanderers," there were five known versions of this prologue, the first partly written on paper watermarked $1859 .{ }^{101}$ It seems likely then, that whatever his response to the reviews of The Defence of Guenevere, Morris started fairly promptly on another even more ambitious venture, redoubling his efforts, as it were, and continued them until the much-improved final result satisfied his intentions. Multiple drafts followed as well as drastic changes in the final version, which May Morris tells us he read to his friends in the summer of $1867 .{ }^{102}$

Only one partial manuscript from his earliest attempts has survived, but May Morris included a stanza from the second or third version in her introduction to volume 3 of the Collected Works, ${ }^{103}$ and she printed the entire

98. The Story of Grettir the Strong, translated from the Icelandic by William Morris and Eiríkr Magnússon, London: F. S. Ellis, 1969. One of the Grettir sonnets was used as an epigraph to the translation in 1869, and May Morris printed the second in CW, 7:xix.

99. Ibid. 3:xiii.

100. Florence Boos, "Ten Journeys to the Venusberg: Morris's Drafts for 'The Hill of Venus."

101. "Unpublished Tales for the Earthly Paradise," William Morris Archive, http:// morrisedition.lib.uiowa.edu/ep.html. Latham describes the manuscript: "The 68 paper folios of $a_{1}$ are in an oblong notebook four inches long and six inches wide. Some of the folios are partially watermarked 'nders' and '1859.'” May Morris seems to describe only four versions, however, including the final one Morris read to his friends in summer 1867. An autograph of the penultimate version is in B. L. Add. MS. 45,305, ff. 9-73, and a near-final version in B. L. Add. MS. 37,499, ff. 2v-118.

102. $C W, 3: x v$. The 1867 date for the later version is also consistent with other sources.

103. Ibid., xiv. It is sometimes not entirely clear which manuscript May Morris is discussing. Her description seems to mention only three in addition to the final version: "[The prologue] was first of all written in four-line stanzas, and there are a few other verses of two other beginnings in the same measure." Since versions two and three are missing, could these have consisted only of openings? 
penultimate version in volume $24 .{ }^{104} \mathrm{I}$ have examined the two final versions elsewhere, ${ }^{105}$ and will here consider Morris's first intentions in the earliest version of "The Wanderers."

This first attempt's meter, tone, mode of treatment, and use of history differed radically from those of its successors. Blending legend, fiction, and history in an "argument" followed by more than fifteen hundred lines devoted to the Wanderers' sojourn in a "land of ladies," 106 its ballad stanzas offered a rapid narrative weighed down by a relatively shallow collection of swashbuckling protagonists, described in a later version as pirates, merchants, and mariners, and characterized here as "knights," merchant-adventurers, and dubious soldiers of fortune. The "argument" for this crude and picaresque first version suggested that the Wanderers had first sailed southwest to Africa, where they encountered a "land of the blacks" and a "land of ladies" as well as a necropolis of "stony men" (an anticipation of the final version's "The Writing on the Image"), before they finally reached the "land whereof they had dreamed." 107

May Morris believed that the source for the original idea for The Earthly Paradise was "St. Brendan's Voyage" ("The Lyfe of Saynt Brandon") in William Caxton's 1483 version of The Golden Legend. ${ }^{108}$ This provenance was not implausible, for Morris drew on The Golden Legend as a source for "The Story of Dorothea," another discarded Earthly Paradise draft. According to Caxton's text, Brendan sailed with fourteen companions in search of the "land of Behest tofore the Gates of Paradise," found a pleasant monastery run by a hospitable abbot, did battle with assorted cinematic sea monsters, and finally reached "the fairest country that any man might see," before he and his fellows

104. Ibid., 24:87-170.

105. Florence Boos, The Design of William Morris's “The Earthly Paradise," chap. 4, pp. 39-66; "The Evolution of 'The Wanderers' Prologue." In the fourth version printed in CW, vol. 24, the marauders swiftly dispatch many black natives, burn their "filthy God," and steal their cattle, only to be ambushed when sleeping and forced to flee lest they in turn "die like shriveled leaves" (107). This version seems rather evenhanded in presenting the overconfidence and blindness of the would-be conquerors.

106. Its lines correspond with lines 1081-2458 of the 2610-lined "Prologue: The Wanderers" in $C W$, vol. 24 .

107. The land of ladies still remains in the fourth version printed by May Morris in $C W$, 24:121-42. Also, these Wanderers murder some of the natives they first encounter, in contrast to the more tolerant and fair-minded Wanderers of the final version.

108. "Life of St. Brandon," vol. 7 of Jacobus de Voragine, The Golden Legend, or, Lives of the Saints, as Englished by William Caxton, 48-66. Morris printed this at the Kelmscott Press in 1892 as The Golden Legend of Master William Caxton Done Anew. For St. Brendan, see The Voyage of St Brendan: Representative Versions of the Legend in English Translation, ed. W. R. J. Barron and Glyn S. Burgess (Exeter: University of Exeter Press, 2002). 


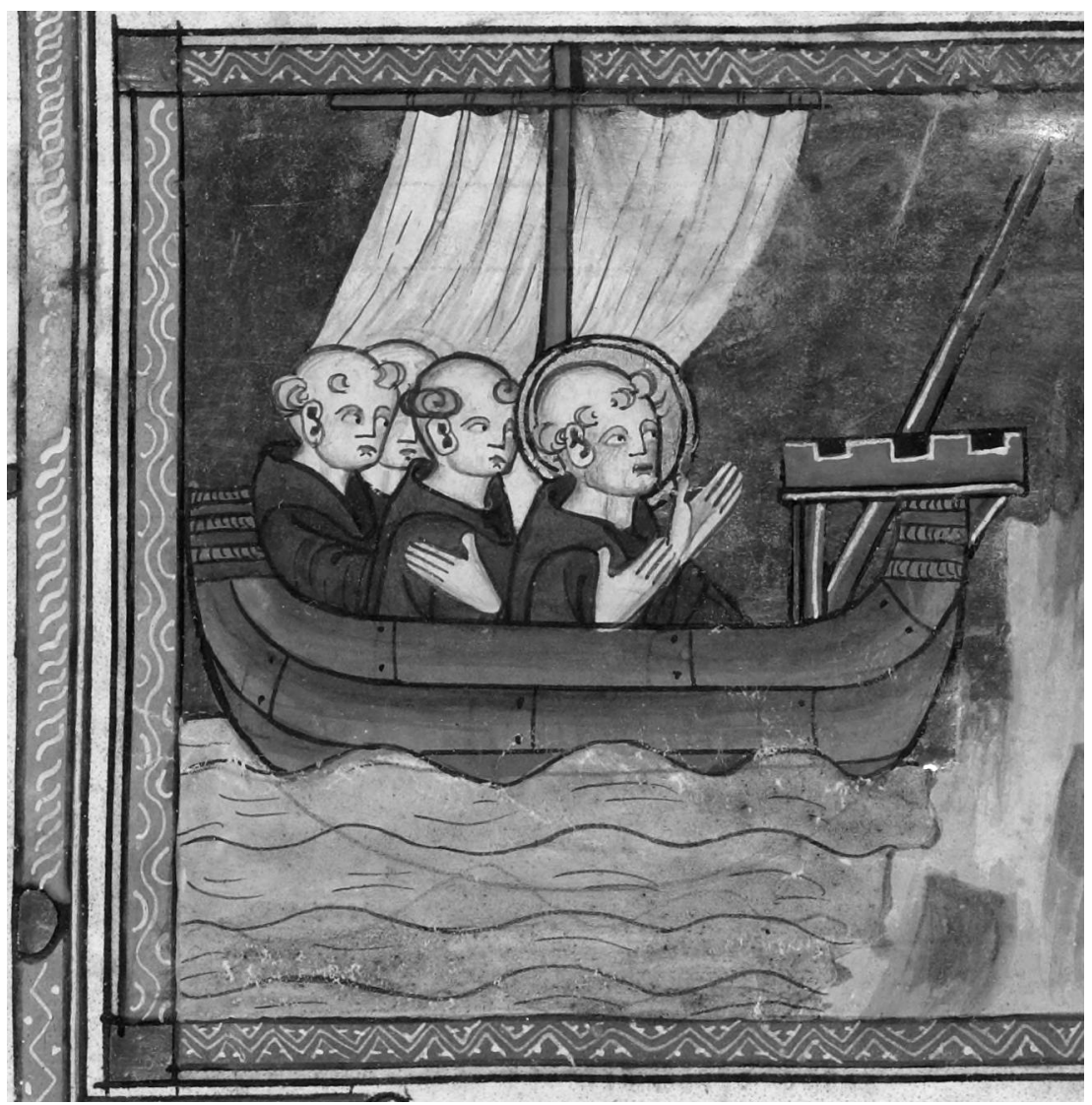

FIGURE 21. St. Brendan's Voyage, illuminated manuscript. Courtesy of the Bibliothèque nationale de France.

were forced to leave. ${ }^{109}$ Aspects of this journey resembled counterparts in the finished Earthly Paradise, but the differences were vast. The final "Wanderers" were Norwegian mariners in flight from the Black Death, not Irish monks; they sailed to a Greek island rather than an uncharted Neverland; and the mutual loyalty of two close friends, absent from "Brendan," is central to the final version. ${ }^{110}$

109. See Florence Boos, “The Sources for Morris's 'Wanderers' Prologue” and The Design of William Morris's "The Earthly Paradise," chap. 4, pp. 61-66.

110. Another possible source for the later version was published in 1866, the first version of Sabine Baring-Gould's Curious Myths of the Middle Ages (London, Oxford and Cambridge: Rivington, 1866); second edition, revised and enlarged (London: Rivington, 1868), both of 


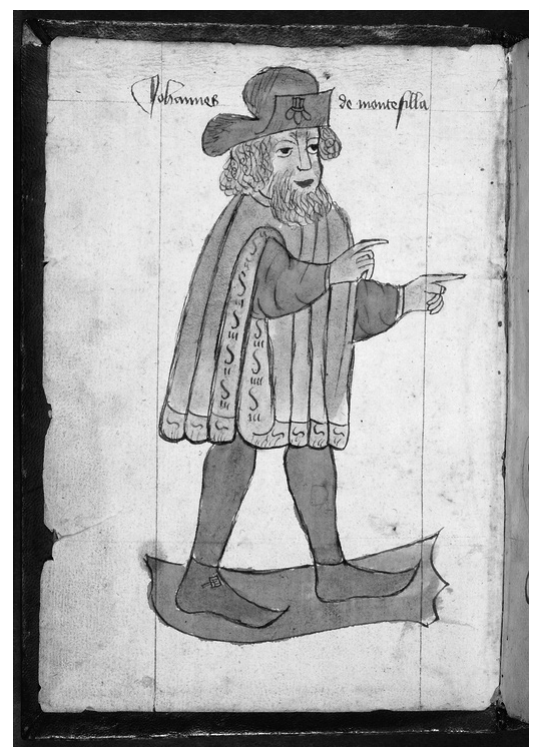

FIGURE 22. Sir John Mandeville, 1459 illustration. Courtesy of the New York Public Library Digital Gallery.

Another possible source was Sir John Mandeville's The Voiage and Travaile of Sir John Maundeville, published in London in 1839 and reissued by Morris's friend F. S. Ellis in $1866 .{ }^{111}$ In the published text of Morris's "Prologue: The Wanderers," the principal narrator Rolf remembers that his friend Nicholas had said "an English Knight / Had had the Earthly Paradise in sight,"112 and when someone asked Morris who this "English Knight" was, he replied that "I meant Sir John Mandeville .. . You may remember that he spins a long yarn about the sham Earthly Paradise of the sheikh of Alamont."113

As for Morris's Scandinavian mariners, he was already aware at this stage of Paul Mallet's Northern Antiquities and Samuel Laing's translation of the

which contain a chapter-length summary of different forms of "Terrestial Paradise" (1866: 229-41).

111. The Voiage and Travaile of Sir John Maundeville. May Morris mentions that "by this time [late 1867] my father had grown into close acquaintance with Mr. F. S. Ellis, a bookseller of King Street, Covent Garden ... he offered to undertake the future editions of 'Jason,' and this was the beginning of a life-long friendship between poet and publisher" ( $C W, 2$ :xviii).

112. "Prologue: The Wanderers," 1l. 145-46, The Earthly Paradise, ed. Florence Boos, 75.

113. O. F. Adams and W. J. Rolfe, eds., Atalanta's Race and Other Tales from The Earthly Paradise (Boston: Ticknor, 1888), 197; Kelvin, Letters, 2:671. 
Heimskringla ${ }^{114}$ which described westward voyages by Scandinavians in search of land to settle and colonize. Precedents for the earlier draft's land ruled by women could be found in accounts of the "Amazons" by Herodotus and other classical authors, and more immediately in the "city of ladies" and women's college of Tennyson's 1847 The Princess, and Morris's own "Ladies' Gard” in the Defence poem "Golden Wings." Whatever their multiple origins, the details of Morris's framing devices were original departures from more familiar Arthurian, Anglo-Saxon, Dantean, and biblical models, and they improved as they evolved in subsequent drafts. The successors of the initial wandering freebooters were "moved by a dream" of peace and refuge from the bubonic plague, not acquisition. ${ }^{115}$

Songs, inner tales, and performances of various kinds were already present in the earlier drafts. In the first draft of "The Wanderers," for example, a series of tableaux are presented to the travelers and their female hosts:

There saw we how that Theseus slew

The beast by aid of a poor may

To whom not long abode he true

There saw we the Knight Perseus slay

The evil things by the sea side

There was the noble story told

Of those good knights that wandered wide

With Jason for the fleece of gold (11. 1369-76)

Similarly, in early advertisements for The Earthly Paradise in the endpapers of The Life and Death of Jason (1867), "The Story of Theseus" and "The Doom of King Acrisius" (the Perseus legend) were on offer, and Jason itself was originally conceived as an Earthly Paradise tale until its length got out of hand. ${ }^{116}$

114. Paul Mallet, Northern Antiquities, and its successor, Samuel Laing's extended introduction to his translation of the Heimskringla, or, Chronicle of the Kings of Norway. A few incidents of Mallet's description of the voyages of Scandinavian sailors resemble events in the final version. See also Oscar Maurer, "Some Sources of William Morris's 'The Wanderers."”

115. According to the Swedish historian Sven Lagerbring (Historia, iii, 406), the plague reached Norway in 1349 on a ship that had brought woolen cloth from London. A member of the crew apparently contracted the disease before the ship set sail in May 1349, and the entire crew then died at sea. The vessel drifted aground near Bergen and infected the Norwegians who boarded it. (Francis A. Gasquet, The Great Pestilence [1348-9], Now Commonly Known as the Black Death [London: S. Marshall, Hamilton, Kent, 1893]).

116. No manuscript of "The Story of Theseus" has been found. At the end of vol. 1 of The Earthly Paradise, it was announced as one of the projected tales for the second volume. 
Later on in the post-banquet dancing and conversation, "fair long wooden stages" appeared, and "beautiful old tales were sung / By minstrels that were well beseen. .." (11. 1419-20). The first song remained incomplete, but Morris lifted the second ("In the white-flowered hawthorn brake / Sweet be merry for my sake," 11. 1479-80) from the "Helen's Chamber" section in the unpublished "Scenes from the Fall of Troy." ${ }^{117}$ Both songs were chivalric rather than Scandinavian in tone, as befitted the transitional position of this first draft of “The Wanderers" in Morris's work.

Morris did grant his early Wanderers a range of experience and prior panEuropean adventures, so that when the Queen of the "ladies land" expressed fear that the Emperor who keeps her land in thrall will also threaten their new defenders, Rolf offered a proud account of the Wanderers' prior (mercenary) feats:

And some of us have fought in France

And some in Wild Prussia have been

And some in Spain have led the dance

And unafraid the moors have seen (11. 1109-12)

He himself, in another bow to Froissart, had fought for King Edward III in Flanders: ${ }^{118}$

Ye see this jeweled collar shine

About my armour this to me

The King of England with his hand

Did give me in his own galley

By Sleuse town in the Flemish land (11. 1264-68)

It is unclear why someone named "Rolf" had fought to uphold the claims of the British crown in France, but his proud recollection dated their voyage after one of Edward III's campaigns in the 1340s. In another eclectic touch, derived from Morris's reading in the Heimskringla ("Circle of the World"), Rolf claims descent from Norway's quasi-legendary first king:

117. This little song has a complex publication history; after its appearance in the two versions of "Helen's Chamber," it was included as "Love and Death" in "A Book of Verse," and later as an interspersed song in "Ogier the Dane," the August tale for The Earthly Paradise. (For variants, see Latham, “The Wanderers," "Unpublished Tales," notes to lines 1479-1502.)

118. The final version of "Prologue: The Wanderers" dates the poem's setting carefully about 1349; here Rolf's service in France had begun earlier, since the naval Battle of Sluys, which marked the beginning of the Hundred Years' War, had occurred in 1340 in an inlet on the border between Zeeland and West Flanders. 
From Harald fair hair am I sprung

And thence from Odin in right line

Who was a God as skalds have sung ${ }^{119}$

Despite his invocation of Odin and the Eddas, Rolf and his companions are pious Christians who travel with a "mass priest," in keeping with the Heimskringla's account of the mass conversion which took place in Norway around 1000. ${ }^{120}$

Rather inconsistently, although the "ladies land" is one in which "men be underneath the yoke" and tapestries are "hung around / With histories where ladies-all / In strife with men full many a wound / Both gave \& took" (ll. 1350-54), the land's women are helplessly and desperately eager to reward the male mercenaries who promise to protect them, and their queen offers Rolf her crown and sovereignty in return for his readiness to defend their city: "Where is your lord that I may give / My crown to him from off my head / And make him king while he shall live" (1l. 1218-20).

A bit of clarity comes to the perplexed reader when the queen explains that their oppressor, the Great King and Emperor, demands that ten maidens be sacrificed each year as tribute to his alleged ancestor Hercules, and would

... sow the place with salt

And yoke young maidens to his plough

And take such vengeance for their fault ...

That when the scourge had torn them well

Fierce fire should burn up the rest (1l. 1435-37, 1440-41)

The Wanderers duly prepare for attack before the account abruptly changes course, the oppressor is forgotten, and the Wanderers settle into years of pleasantness in the "ladies land."

The obvious precedent for this fantasy tale of women 'warriors' who will not fight was Tennyson's 1847 Princess, in which the inhabitants of a once

119. Laing, Heimskringla, "Harald Harfager's Saga," section 9, contains a song, "Glymdrapa," which celebrates King Harald as "the fair-haired son of Odin's line." Odin appears in two of the Eddic poems translated by Morris, the "Lament of Oddrun," $C W, 7: 472-80$, and "Baldur's Doom" [published under the title "Baldur's Dream"], ibid., 185-88.

120. King Olaf I (Olaf Tryggvason) had converted to Christianity before assuming the Norwegian throne in $996 \mathrm{AD}$, and on becoming king promoted the Christianization of his subjects (by force if necessary), and later Norwegian monarchs such as Olaf II (Olaf Haraldsson, or St. Olaf) followed suit. (The Heimskringla, or Chronicle of the Kings of Norway, ed. Samuel Laing, London, 1841, vol. 1, "King Olaf Trygvason's Saga" [sects. 59-61] and "Saga of Olaf Haraldsson" [St. Olaf] [sect. 56]). 
proudly separatist women's college beg for help against their aggressors, but after their "rescue" destroys the college, implausibly marry their invaders. ${ }^{121}$ At least Rolf has the grace and self-awareness to reject the queen's abject offer:

\section{... never will I wear your crown}

For of your law I know not ought

And ye are old and ripe in wit

On many a hard thing have ye thought

And have been used long time to sit

Judging the people day by day. (11. 1276-81)

Rolf's un-Tennysonian refusal may have reflected Morris's interest in Norwegian and Icelandic proto-democracy, for Paul Mallet had asserted in Northern Antiquities that Scandinavian peoples had a natural love of liberty. ${ }^{122}$ A mercenary Rolf was, but an imperialist he was not.

He was, however, a religious proselytizer:

Lady he said...

I read you learn our holy laws

And learn to know the Trinity

The Mother of God and all Hallows

And leave your false Gods- (11. 1288, 1292-95)

True to gender conventions and the extant history of monarchical conversions-cuius rex, eius religio-the queen accepted baptism for herself and her people, but not without a moment of protest

At last she said Sir Holy Man

Too many things at once ye show

121. In the poem's improbable plot, the Prince and his friends are discovered inside the women's college, after which the Prince's father attacks the college on behalf of his son's right to marry the Princess, the Princess's brother takes arms to defend her honor, and the wounded prince avoids direct battle against the woman he wishes to marry. At the end all seems forgiven in the interests of marital harmony.

122. Mallet, Northern Antiquities: "That spirit of liberty, arising from their climate, and from their rustic and military life, had received new strength from the opinions it had produced, ... we see everywhere ... those swarms of Germans and Scandinavians . . . changed into a sensible and free people ... impregnating ... their institutions with a spirit of order and equality" $(126-27)$. 
I will believe all that I can

But pray you cease for a while now

Truly it makes the senses reel

To hear all this all so suddenly

The Gods we sought in woe \& weal

Devils or else a painted lie.

And many things we must believe

That now for the first time we know

And from you by mere chance receive

Or lie in endless fiery woe (1l. 1301-11)

The mixed tonalities of the first "Wanderers" exemplify the problems Morris faced in a narrative whose settings are stereotyped and whose internal narrator is less than uniformly sympathetic. Compatibility with his primary and secondary sources was well and good, but their quasi-factual assertions and more-than-dubious wonders cried out for the respectful but ironic and inquiring tone that would later suffuse his Earthly Paradise in its final version. The first-redaction Wanderers represented only themselves, but their successors could hope to represent the aspirations of humankind.

May Morris did single out the following short passage from one of the early versions of the "Wanderers":

I tell of times long past away

When London was a dry-walled town,

And slow the pack-horse made his way

Across the curlew-haunted down.

From this seedling grew the lovely pastoral passage that opens "Prologue: The Wanderers" in its final form:

Forget six counties overhung with smoke,

Forget the snorting steam and piston stroke,

Forget the spreading of the hideous town,

Think rather of the pack-horse on the down,

The clear Thames bordered by its gardens green; ... . ("Prologue: The Wanderers," ll. $1-5)^{123}$

123. Earlier editions from 1868 onwards begin with "The Apology," which Morris omitted from the final Kelmscott version, 1896-97. 
She also thought the fourth version of "The Wanderers" a "vivid and picturesque piece of work," 124 but acknowledged that "in spite of the swing of the rough verse this prologue is far below the quality of that ultimately published both in design and workmanship." ${ }^{125}$ The shift from ballad meter to pentameter couplets seems to have made it easier for Morris to project his thoughts into his characters, who became in turn more skeptical, more reflective, more companionable, and more distinctly aware of the vast range of cultural perspectives.

In the final version, for example, the bond between Rolf and Nicholas is closer and deeper, as the following eulogy makes clear:

[For] then died the captain, Nicholas,

Whom, though he brought us even to this pass,

I loved the most of all men; even now

When that seems long past, I can scarce tell how

I bear to live, since he could live no more. ("Prologue: The Wanderers," 11. 2663-67)

The earliest version also lacks internal auditors, whereas the interest of the final version's "Elders" and their descendants in the Wanderers' stories offers a sense of solidarity, renewed purpose, and pride in the transmission of a shared cultural past.

In addition to the sources mentioned earlier, the final version also drew on Sabine Baring-Gould's Curious Myths of the Middle Ages (1866) as well as a more thorough study of the Heimskringla, and reflected more nuanced awareness of the grim history of native peoples and their lost traditions derived from works such as William Prescott's History of the Conquest of Mexico (1843), his History of the Conquest of Peru (1847), and Washington Irving's Life of Christopher Columbus (1828). As Morris refined his knowledge of comparative mythology and religion as well as social history, he sharpened the precision of his evocations of fabulous accounts of the past, and deepened his ability to convey its alterity, the frailty of its imperfect transmission, and the eternal recurrence, for good and ill, of primal human emotions.

124. CW, 24:xxix. She continues, "It is a complete story, full of movement and incident, full of strangeness and of almost Eastern imagination-once more, the narrative of a man who saw what he recounted."

125. Ibid. 3:xiv. 


\section{F}

\section{ARLY DRAFTS OF “EARTHLY PARADISE” TALES}

As Morris planned and recast the problematic frame tale of his projected narrative epic, he also worked away at its individual tales. From the evidence that has been preserved, he seems to have begun to draft these by 1861 at the latest, and to have prepared several drafts for most of them. These early drafts focused primarily on two traditional sources of conflict: sexual attraction, seen as destructive as well as benign, and the consequences of overweening pride, avarice, and the lust for power as described in sources such as the Gesta Romanorum. The earliest tales such as "The Proud King" (a fable reproving pride) and "The Writing on the Image" (a warning against sorcery) exhibited these homiletic patterns in their near-original forms, and later-drafted successors individuated them in more nuanced and complex ways.

More precisely, of the ten tales May Morris listed as first drafted in a series of notebooks- "Cupid and Psyche," "The Lady of the Land," "The Palace East of the Sun," "Adrastus" (later rewritten as "The Son of Croesus"), "The Doom of Acrisius," "The Proud King," "The Watching of the Falcon," "The Writing on the Image," "The Story of Dorothea," and "The Deeds of Jason" (later rewritten as The Life and Death of Jason) - eight fit one or the other of these two patterns. $^{126}$

The exceptions were "Jason," which drew on its own classical sources in Apollonius Rhodius's Argonautica, and “The Story of Dorothea," a saint's legend that described a young woman's relentless victimization and martyrdom, which Morris finally decided to omit, in part perhaps because it was simply too painful. ${ }^{127}$ The early studies of Venus's ambivalent sway included "Cupid and Psyche," "The Watching of the Falcon," "The Hill of Venus," and "The Palace East of the Sun" (in which the supernatural erotic figure is a swanmaiden), and the reproofs of pride which goeth before a fall included "The Proud King," "The Doom of King Acrisius," "The Writing on the Image," "The Story of Adrastus," and “The Lady of the Land."

126. Of these ten, seven are in the Fitzwilliam Library, FM EP 25: "The Doom of Acrisius," "The Writing on the Image," "The Lady of the Land," "Adrastus" ["The Son of Croesus"], "The Watching of the Falcon," "The Palace East of the Sun" ["The Land East of the Sun and West of the Moon"], and "The Story of Dorothea" [unpublished]; and two in the British Library: "The Proud King," Add. MS. 45,306, and "The Story of Cupid and Psyche," Add. MS. 45,305. A draft of the latter is also in the Tinker Library, Yale University, and one, "The Deeds of Jason" [The Life and Death of Jason], in the Huntington Library, HM 6434, William Morris Archive, http://morrisedition.lib.uiowa.edu/jason.html.

127. "The Story of Dorothea," Unpublished Tales from "The Earthly Paradise," ed. David Latham, William Morris Archive, http://morrisedition.lib.uiowa.edu/dorotheaportal.html; Florence Boos, The Design of William Morris" "The Earthly Paradise," 400-45. 
One very early draft has not yet been mentioned. May Morris thought her father may have begun "The Man Born to Be King" as early as 1858, and that drafts of this tale, ${ }^{128}$ "The Proud King," and "The Watching of the Falcon" were completed by $1861 .{ }^{129}$ Morris also wrote five tales in tetrameter- "The Man Born to Be King," "The Writing on the Image," "The Watching of the Falcon," "The Palace East of the Sun," and "The Ring Given to Venus"130 - a meter Morris seems to have used for his earliest drafts and discarded as he went along. The first of these- a tale of a good-hearted peasant youth who gains the love of a princess-exemplified the reproof-of-pride template, in this case the attempts by the princess's father to thwart a divine prophecy that he will be supplanted by someone of low degree. ${ }^{131}$ "The Ring Given to Venus" combined two of these schemata in its tale of a young man whose compulsive attraction to Venus threatens his forthcoming marriage, and a repentant former sorcerer who gives him a scroll that releases him from the goddess's powers.

These early drafts drew on a wide range of medieval sources, some of them mentioned earlier: the Gesta Romanorum, Caxton's Golden Legend, William of Malmesbury's De Gestis Regum Anglorum, Mandeville's Travels, Jean d'Arras's Tale of Melusine, Benjamin Thorpe's Northern Mythology and Yuletide Stories, George Dasent's Popular Tales from the Norse, the Grimm Brothers' German Popular Stories, and perhaps Marie de France's "Lai de Lanfal." 132

128. $C W, 3: 70-71$. The early draft emphasizes the contrasting births of princess and cottager. The Queen's child, as her mother had desired, is "Red as blood and white as snow, / And yellow as gold mote she be, / Great joy this would be to me." By contrast, the little boy, born the same night in "a small house poor and forlorn," learns the useful woodsman's skills which enable him to begin his adventures and find the princess.

129. Ibid., 6:xxvii.

130. In her introduction to $C W$, vol. 5 , xxiii, when quoting tetrameter lines from the first draft May Morris speaks of her father's "earlier and looser narrative verse," and I am assuming that "looser" here means a rough four-beat line. Similarly, she describes the uneven tetrameter of a draft of "The Man Born to Be King” as being "in my father's younger manner-full of vigorous, imperfect and impatient verse, different indeed from that of the published "Earthly Paradise"” (ibid., 3:xvi).

131. "The Ring Given to Venus" also seems to have been fair copied for the printer relatively early, then retained in manuscript until finally used. The manuscript is marked for accompanying pictures, as part of an early plan for an edition of The Earthly Paradise to be illustrated by Edward Burne-Jones. In The Book That Never Was, Joseph Dunlap mentions that Burne-Jones prepared at least one sketch for "The Ring Given to Venus" for the proposed edition (13). Tales that were marked in manuscript for illustration, and thus among the earliercomposed tales, are listed in a later note.

132. Gesta Romanorum, ed. Sir Frederic Madden (London: Roxburghe Club, 1838); William of Malmesbury, Chronicle of the Kings of England; George Dasent, Popular Tales from the Norse; Benjamin Thorpe, Northern Mythology, and Yule-Tide Stories: A Collection of Scandinavian and North German Popular Tales and Traditions (London, 1847); Jacob and Wilhelm Grimm, German Popular Stories. 
Early lists of projected tales also indicated plans for some which were apparently never written- "The Seven Sleepers" and "The Story of Theseus"or which May Morris believed had been written but were lost- "The King's Treasure House," "The Dolphins and the Lovers," "The Fortunes of Gyges," and "Amys and Amillion." Finally, four more extant manuscripts were completed but not included in the cycle-in addition to the discarded versions of the "Wanderers" prologue, "The Story of Dorothea," "The Story of Orpheus and Eurydice," 133 "The Wooing of Swanhild," and "The Story of Aristomenes."134

May Morris commented at one point that "Morris always had a yearning for illustrations to his poems; he saw the stories in brilliantly-defined pictures, and desired that other people should do so, too."135 He began his study and collection of illustrated books in the 1860s, and by 1865 he and BurneJones were at work on a projected illustrated edition of The Earthly Paradise, planned to include more than three hundred illustrations, more than a hundred of which had been completed before they set aside the ambitious project in $1868 .{ }^{136}$ Many of the fair-copied early drafts bore "X"s in the margin or overleaf to indicate placement of these illustrations, often with small captions. ${ }^{137}$

133. At the end of Jason the publisher's announcement lists the projected Earthly Paradise tales as including "The Story of Theseus," "The King's Treasure House," "The Dolphins and the Lovers," "The Fortunes of Gyges," "The Queen of the North," and "The Seven Sleepers." However, by the announcement at the end of vol. 1 of The Earthly Paradise, "The King's Treasure House," "The Seven Sleepers," and "The Queen of the North" have been dropped, but "Amis and Amillion" has been added.

May Morris then records that Edmund Gosse recalled hearing Morris read a draft of "Amis and Amillion." She herself claims that he did complete five unused drafts (exclusive of the slightly later "The Story of Aristomenes" and "The Wooing of Swanhild"), including "The King's Treasure-House," The Dolphins and the Lovers," and "The Fortunes of Gyges" (CW, 3:xiii). No mention of these three titles occurs again in her frequent and lengthy discussions of Morris's notebooks, drafts for tales, and minor writings, and moreover, since she would have been six years old at the time of the publication of the first volume of The Earthly Paradise, her knowledge of these allegedly written but discarded tales would inevitably have been secondhand. She does, however, mention in the introduction to $C W$, vol. 24, that Morris's unfinished "In Arthur's House" could be a draft for "The Queen of the North" (xxxi) (if so, it may have been written fairly early, since it is written in a rough tetrameter style).

For the four tales that were never published, but of which drafts survive, see "Unpublished Tales from the Earthly Paradise," ed. David Latham, William Morris Archive, http:// morrisedition.lib.uiowa.edu/ep.html.

134. Latham notes that "Swanhild" was written on paper watermarked 1868 and "Aristomenes" on paper watermarked 1870; the latter was later published in the Athenaeum 13 May 1876.

135. AWS, 1:402.

136. Dunlap, The Book That Never Was, 13 .

137. Cf. CW, 24:xxix; Dunlap, Book That Never Was, 10. In addition to these marks on the penultimate version of "The Wanderers," such notations appear on drafts for "Cupid and Psyche," "The Proud King," "The Doom of King Acrisius," "The Writing on the Image," "The 
The list of these tales was more or less coextensive with the ones first planned, and several chosen were "Venus" tales in which the goddess herself literally appears. Even the earliest drafts, and certainly those from the period 1865-68, would have been influenced by Morris's desire to present clear images for these illustrations.

May Morris offered the following rather striking account of Morris's many versions:

If you had seen and handled those seven great folio volumes of The Earthly Paradise, fair copies and drafts, you would be particularly impressed by the work this perfectionist put into his poetry. You would have to remember, also, that some twenty or so other MSS of single stories exist in one form or another. ${ }^{138}$

At least twenty-six of these drafts for the tales, excluding the prologue and additional lyrics, collected by May Morris, Charles Fairfax Murray, and others, have been preserved in the British, Fitzwilliam Museum, Yale University, and Huntington Libraries. ${ }^{139}$ Since May Morris referred to at least twenty-four in her introductions, she would have seen almost all of them. ${ }^{140}$

Even this is not the whole story, however, for David Latham has marshalled evidence that many manuscripts described as first drafts were actually later revisions. The first written stage, he suggests, was often in the form of scribbled notes in pencil, sometimes on scrap paper, later transferred to small

Lady of the Land," "The Watching of the Falcon," “The Ring Given to Venus," "The Hill of Venus," "The Story of Dorothea," "Pygmalion," "The Palace East of the Sun," and "The Deeds of Jason."

138. AWS, 1:401.

139. See "List of Drafts for The Earthly Paradise," William Morris Archive, http://morrisedition.lib.uiowa.edu/listepdrafts.html.

140. In her introductions to the Collected Works and in Artist, Writer, Socialist, vol. 1, she lists many of these first or rejected drafts; as we have seen, she mentions four for the "Prologue," and in addition one each for "The Man Born," "The Proud King," "The Watching of the Falcon," The Lovers of Gudrun," "The Ring Given to Venus," "The Death of Paris," "The Palace East of the Sun," "Bellerophon in Argos," and "Bellerophon in Lycia"; an unspecified plural number for "The Man Who Never Laughed" and "The Story of Rhodope"; three for "Cupid and Psyche"; and four for "The Hill of Venus." She cites passages from "The Man Born to be King" (CW, vol. 3), "The Story of Cupid and Psyche" (vol. 4), "The Land East of the Sun," "The Man Who Never Laughed Again," "The Story of Acontius and Cydippe," "The Story of Rhodope," and "The Lovers of Gudrun" (vol. 5), and "Bellerophon in Lycia," "The Ring Given to Venus" (facsimile page), and "The Hill of Venus (vol. 6). In "Narrative Poetry: The Earthly Paradise," in AWS, 1:396-436, she returns to the topic again, giving quotations from early versions of "The Proud King," "The Watching of the Falcon," “The Story of Rhodope," “The Ring Given to Venus," "Bellerophon at Argos," and "The Hill of Venus." For a list of drafts for The Earthly Paradise, see Florence Boos, William Morris Archive, http://morrisedition.lib.uiowa.edu/listepdrafts.html. 
pocketbooks, and only afterwards entered into the larger folios and notebooks of the later drafts. Using as his examples "The Story of Aristomenes," a discarded Earthly Paradise tale, and a passage from "The Folk of the Mountain Door," a discarded prose romance, he concluded that "the letterhead scrap paper shows how hard Morris had to work on even the simplest verses. It suggests that the typical long folios are not the first drafts of Morris's poems." ${ }^{141}$

Given the evidence we have, it seems likely that we will never be able fully to reconstruct Morris's process of composition in this period, but a number of clear handwritten drafts marked for illustrations, preserved in notebooks in the Fitzwilliam Museum Library, ${ }^{142}$ may be examples of the intermediate fair copies Latham has identified. Most of them lack the detailed settings, historical nuances, and resonant allegories of their final successors.

Consider, for example, "The Hill of Venus," which Morris wrote out in at least ten drafts, some of them incomplete. One of these, prepared in fair copy and accompanied by a list of illustrations, ${ }^{143}$ is an exemplum of Morris's transitional early style and thematic concerns. Its subject was the legend of Tannhäuser as conceived by Ludwig Tieck, which Thomas Carlyle had translated in his 1827 compendium of German Romance, and which was brought to the attention of Victorians once again in 1861 in an anonymous translation in Once a Week, and in Tannhäuser, or the Battle of the Bards, a satiric poem by Robert Bulwer-Lytton and Julian Fane. ${ }^{144}$

141. David Latham, “'A Matter of Craftsmanship': William Morris's Manuscripts," 9. Even May Morris notes that in addition to what she calls "the first draft" in manuscript books, there are "some fragmentary notes, and two or three small note-books containing portions of the earliest tales in swift pencil writing" ( $C W, 2: x x v)$.

142. FW EP 25, donated by C. F. Murray. These tales in the Fitzwilliam include "The Man Born," "The Doom of King Acrisius," "The Writing on The Image," "The Lady of the Land," "The Watching of the Falcon," "Adrastus" ("The Son of Croesus"), "The Palace East of the Sun," "The Lovers of Gudrun," and "The Hill of Venus." A clear mate to these is "The Deeds of Jason," Huntington Library HM 6434. Of these nine Fitzwilliam drafts, six had been marked for illustration: "The Doom of King Acrisius," "Writing on the Image," "The Lady of the Land," "The Watching of the Falcon," "The Palace East of the Sun," and "The Hill of Venus."

143. Florence Boos, "Ten Journeys to the Venusberg: Morris's Drafts for 'The Hill Venus," 613, Appendix, autograph no. 2. FW EP 25 is accompanied by a copyist's list of illustrations that correlates with Morris's notations on facing pages.

This Fitzwilliam EP 25 seems to have provided a basic text from which a copyist prepared the quite similar Huntington Library MS 6423, and Morris annotated this draft with a few corrections, additions, and running notes; the minimal nature of these changes in a relatively fair copy suggests that it was then intended as a near-"final" text for the tale's early version, though later superseded.

144. Ludwig Tieck, "Der Getreue Eckart und der Tannerhäuser," in Thomas Carlyle, German Romance: Specimens of Its Chief Authors, vol. 2 (Edinburgh, 1827). Julian Fane and Robert Bulwer-Lytton had published their satire, Tannhäuser, or the Battle of the Bards, under the pseudonyms Neville Temple and Edward Trevor (London, 1861). An anonymous translation also appeared in Once a Week 5 (17 August 1861), 210-12. 
Morris, Swinburne, and Burne-Jones seem to have shared an admiration of the Tannhäuser legend, for it was also the subject of Swinburne's "Laus Veneris," published in Poems and Ballads in 1866, and of Burne-Jones's 1861 watercolor and later oil painting of the same title (1875-78). Burne-Jones recorded that in 1866 he prepared twenty designs for "The Hill of Venus," and their subjects corresponded closely with the list attached to Morris's early draft. $^{146}$

Like other early medieval Earthly Paradise tales ("The Writing on the Image" for example), this version of "The Hill of Venus" had a rather selfconsciously artificial frame, and gave more attention to tournaments and chivalric combats in the manner of The Defence of Guenevere. Venus also resembled more closely her kindlier and more straightforward incarnations in "The Watching of the Falcon" and other early tales, for she sadly warned her lover "Amyot" that he might later be exiled from her cave.

The plot of the early "Hill of Venus," like that of its companion "The Ring Given to Venus," also focused heavily on sorcery's stereotypical evils. In the opening narrative frame, for example, a friendly old man warned the unnamed narrator that Venus's sorcery had destroyed all who had come before him, and he himself had once seen "the God of heaven mocked most horribly / By things that coming out from yonder hill / In uncouth guise danced on the herbage green." ${ }^{147}$

Amyot, the protagonist of this early tale ('Walter' in its final counterpart) is a fairly shallow character, drawn to the "hollow hill" by racy descriptions of what could be seen and experienced therein. Like his more dignified counterpart in "Pygmalion and the Image," he is dissatisfied with women's "hard light hearts, so ready to forget," and enters the cave to try his fortune. Once inside, he makes his way to a luxurious medieval city of "gilded spires and vanes," borne aloft "from the fair walls by carven turrets high," where he finds a band of beautiful women, who sing the first of two songs in the goddess's praise:

Lo our Queen is at the door

Gold-clad, yet her hair is wet

With the washing of the sea,

O sweet Queen, we kneel to thee.

145. Dunlap, The Book That Never Was, 13.

146. Eight are preserved in the library of the Birmingham Museum and Art Gallery, and are reproduced on the William Morris Archive, http://morrisedition.lib.uiowa.edu/eptextssuppleillus.html.

147. May Morris prints excerpts in $C W, 6: x v i-x x v i$. 
Led to Venus's retreat by one of her servants, Amyot falls asleep, and awakens as Venus enters, undresses, and remains with him and a servant until "the middle of next day." She bids him fight in a tournament she is scheduled to oversee the following day, and promises to reveal herself afterward "[a]s when from out the green sea first I came / Hidden of nought." When her most attractive attendant leads him to the lists, they hear Venus's attendants sing "Before our Lady came on earth, / Little there was of joy and mirth," a graceful song that Morris retained in the published tale.

But after Amyot has made a dutiful sacrifice at Venus's altar and prevailed against an assortment of generic opponents, a sense of entrapment and foreboding overcomes him:

And in his mind again the ill thought came

That all those things he saw, were but shadows

Set round him but to keep his heart aflame.

The smiling folk, the graceful girls in rows,

His damsel, and the bodies of his foes,

All were but deadly meshes of her net

About his fluttering soul in order set.

Venus does cheer him up a bit when she invites him to a walled garden where her "body fair / Naked within his arms did Amyot hold / [until] Therewith they vanished through the gates of gold," and Amyot remains there with her for about five months.

At length, however, as befits an elemental sea-born goddess, Venus is cyclically overtaken by homesickness for her native Cyprus:

She woke, and fell a-longing for the sea,

And the broad yellow sands of her old home,

Where by their black boats fisher people be;

And longed to hear the wind sing mightily

With little changing song from point to point,

And in its waves her body to anoint.

Here the narrator makes no judgment, but Amyot feels devastated:

Left all alone within this wicked place;

Left naked of her love, and growing old. 
At this point Venus's attendant reappears to offer him a generous consolation prize: her love, and prolonged youth ("[f] or I have charms to hold grim eld at bay"). He firmly rejects this distracting offer in order to return to the outer world, however, and instead joins a band of pilgrims in search of a papal audience. Arrived with the others in Rome, he recounts his experience to the pontiff, whose harsh rebuke ("Go hence, thou hast no grain of hope") causes him to faint away in despair. Later the pontiff's rod blossoms as a sign of Venus's favor to Amyot, and the repentant pope vainly seeks Amyot to ask his forgiveness until his own death overtakes him, but neither he nor we ever know whether

Dame Venus took him for her knight

Again ..., or what else befell

Unto him as he journeyed on to Hell.

All the narrator can offer is a parable of death, rebirth, and redemption:

Therewith the old Knight ceased and I sat still

Thinking of all the story I had heard;

And pondering on that unmatched dreadful hill

I deemed that verily the old Swineherd

Had spoken unto me a timely word.

Yet in my heart there lingered none the less

Regretful longing for that loveliness.

And thinking of the joy that I had had

To hear that tale I said, “Men's miseries

May sometimes chance to make their fellows glad

Now the shadow of them in likewise

Will bring the happy tears into our eyes

Like too sweet music too soon passed away."

Therewith the minster chimes sung out midday.

Complements of this erotic allegory appeared in other early Earthly Paradise narratives, among them "Atalanta's Race" and "The Lady of the Land," and its imbricated frame structures paralleled those of "The Land East of the Sun." Its use of interpolated popular songs, a quasi-chivalric medieval ambiance, and the motifs of displacement and deferred reconciliation became central aspects of the Earthly Paradise cycle. 


\section{ONCLUSION}

The nine-year period between the publication of Morris's Defence of Guenevere and The Life and Death of Jason was a little-noticed period of poetic refinement and germination. After surviving a gauntlet of unsympathetic reviews, Morris experimented with a variety of 'new' forms and metrics, and he improved them through a series of more and more flexible and polished drafts. The results showed few traces of then 'modern' poetic practice, but he enlarged his canvas to accommodate a much wider range of classical, Danish, Icelandic, Near-Eastern, and middle-European settings in an effort to understand past emotions and modes of thought. His turn to personal lyrics also enabled him to find more direct and introspective forms of expression, and his work on the awkward balladic frame of the original "Wanderers" honed his skill at the quasi-historical ballads to which he returned from time to time throughout his life in his poems and translations from the Old Norse.

The Earthly Paradise's shift from poetry of battle and physical combat to poetic narratives of travel and search provided better metaphors for the artistic interests and endeavors of Morris's active adult life, and enabled him to broaden his focus from the imprisoned, suffering, and combat-driven protagonists of the Defence. These later meditative "quest" narratives also refined his views of endurance, consolation, and the complexity of human emotions.

The plan of a cycle of tales from many centuries and lands, each reflecting the human longing to escape in the service of the protagonists' varied cultures and ideals, also encouraged Morris to search for a wider and more eclectic range of subjects than the narrowly English/French and quasi-patriotic topics of The Defence, and this pluralism stood him in good stead in his use of multiple and later versions of traditional tales. The vastness, detail, and moral ambiguity of history he encountered also provided ever new topics for exploration and new modes of approach, not only in The Earthly Paradise, but also in Sigurd the Volsung, The House of the Wolfings, and most explicitly in the complex political ideals of A Dream of John Ball and The Pilgrims of Hope (based respectively on the Peasant Revolt of 1381 and the Paris Commune of 1870).

Morris himself expressed (albeit in a very different context) a personal desire to "keep the world from narrowing on me, and to look at things bigly and kindly," ${ }^{148}$ and the open-ended literary counterparts of this desire focused on the palimpsestic and even aleatory aspects of literary transmission and his-

148. Letter to Aglaia Coronio, 25 November 1872, Kelvin, Letters, 1:173. 


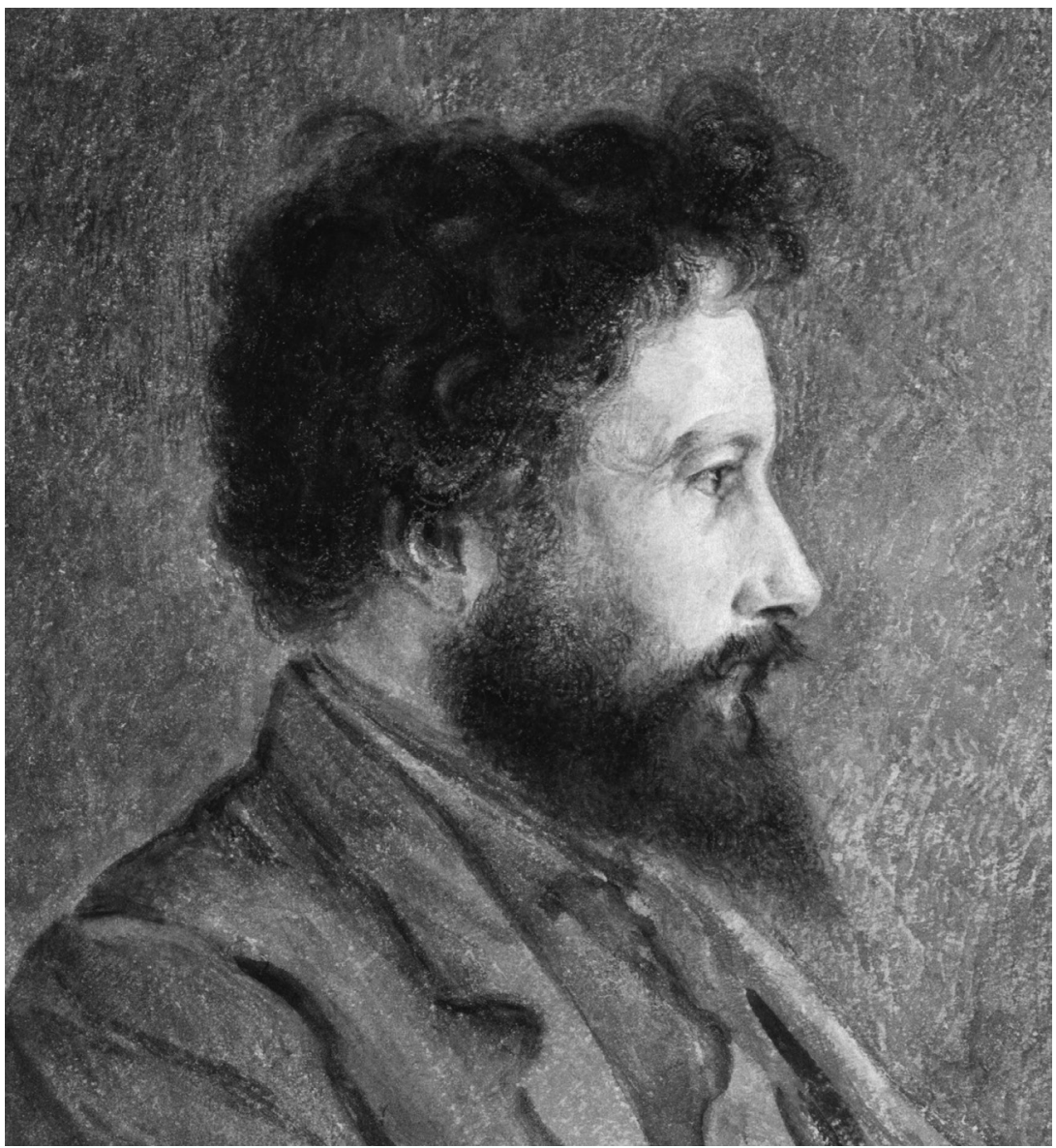

FIGURE 23. William Morris, by Charles Murray, 1870. Courtesy of the National Portrait Gallery.

torical memory, saved by fleeting acts of empathy and cross-temporal understanding from the "the beating of the steely sea."

The appearance of The Earthly Paradise in 1868 also marked a humbler and more personal turn. Never again did he dedicate a book to a poetic or artistic contemporary, as he had done "To my friend, Dante Gabriel Rossetti, painter" in The Defence (a dedication omitted from the Kelmscott Press edition of 1892). The Earthly Paradise was doubly dedicated, on a prefatory page, "To My Wife" - a dedicatee who would presumably apply personal standards 
of poetic judgment; and in its "Envoi" to Geoffrey Chaucer, "great of heart and tongue," to whom he offered a poetic testimony:

Death have we hated, knowing not what it meant;

Life have we loved, through green leaf and through sere,

Though still the less we knew of its intent ... (11. 85-87),

with the hope that Chaucer, who "sweet-souled, didst never stand alone," would accept his homage:

Fearest thou, Book, what answer thou mayst gain

Lest he should scorn thee, and thereof thou die?

Nay, it shall not be. Thou mayst toil in vain,

And never draw the House of Fame anigh;

Yet he and his shall know whereof we cry,

Shall call it not ill done to strive to lay

The ghosts that crowd about life's empty day. (11. 99-105)

In effect, Morris's "Envoi" dedicated his book twice: to his life partner, for better for worse; and to an idealized embodiment of the marriage of true minds:

For ever as thy fashioning did grow,

Kind word and praise because of thee I won

From those without whom were my world all gone,

My hope fallen dead, my singing cast away,

And I set soothly in an empty day. (11. 10-14)

Critics who have seized on Morris's use of the word "idle" in the "Apology" have ignored the implications of "empty" in such passages; the "empty day" was his own time, which he strove briefly to fill with "idle" (imaginative) efforts to understand past emotions. And this was the sense in which

No little part it was for me to play

The idle singer of an empty day. (1l. 111-12) $)^{149}$

As Morris had immersed himself in dusty chronicles, he became increasingly conscious of his role as an intermediary of earlier historians of mentalités, as it were, a then 'modern' voice for the private emotions and public lives

\footnotetext{
149. For a parallel with Walter Benjamin's conception of "empty time" as contrasted with the Jeitzet, see "Theses on the Philosophy of History," 253-64.
} 
of others silenced by time and death. As a visual artist, he thought in terms of replicating structures as well as sensations and thoughts, a trait that enabled him to take pleasure in a sort of 'eternal return' of condensed and expanded lyric and narrative forms, embodied in early efforts such as the quasi-sonnet "Summer Dawn" on the one hand and the verse-drama "Sir Peter Harpdon's End" on the other. As he developed as a poet, he also came to believe that his historical research had helped him preserve a duality of privacy and detachment - the intimacy of personal lyrics, and the detachment (and inadequacy) of historical judgment.

Something of the antiphonal recalibrating of these polarities, moreoverprivacy and engagement, emotion and fact, expansion and restraint, commitment to visual forms and their verbal counterparts-underlay Morris's character and literary work, in ways that were expressed in one of J. W. Mackail's assessments of his personality.

And all the while he led his own inner life, apart and alone in a world of his own - a life of brooding thought and romantic imagination, in which the whole framework of things and the whole history of the race lay before his eyes as though in some magic crystal. "It seems to me," he wrote once, "that no hour of the day passes that the whole world does not show itself to me." The strength of this inner life made him self-absorbed.... But his rare words of comfort ring true in their austerity. "I entreat you to think," he wrote once to his dearest friend, "that life is not empty nor made for nothing, and that the parts of it fit one into another in some way." ${ }^{150}$ The words sound a little

150. William Morris and His Circle, 18. "For strength, for stimulus, for guidance in work you would go to him: hardly for consolation in trouble, or for comfort in perplexity." I find this judgment puzzling, the more so as Mackail may have been echoing the opinions of the Burne-Joneses. The letter appeared in Mackail, Life, 1:327-28, with the opening and closing removed, and is reprinted in Kelvin, Letters, 1:291, written from Leek and dated [22 March-6 April 1876]. The addressee must be Edward Burne-Jones, for however close Morris may have been to Georgiana Burne-Jones, both Mackail's Life of William Morris and her Memorials of Edward Burne-Jones describe Edward as Morris's closest friend. Moreover, the letter is an eloquent statement of attachment: "though my life is dear to me, so much as I seem to have to do, I would give them away, hopes and pleasures, one by one or all together, and my life at last, for you, for my friendship, for my honour, for the world. . . . I wish I could say something that would serve you, beyond what you know very well, that I love you and long to help you: and indeed I entreat you (however trite the words may be) to think that life is not empty nor made for nothing." Although Fiona MacCarthy's The Last Pre-Raphaelite doesn't suggest any cause for Burne-Jones to have felt despair in 1876, she documents that his attachment to Marie Zambaco continued for many years after their supposed rupture in 1869 , and he may have felt Morris was less than sympathetic to extramarital attachments. It should be noted that Morris's "The Death of Paris" treats a similar triangulation of man-lover-wife with sympathy for all parties. 
cold, a little abstract. But he would not go beyond what he felt to be the truth; and it is in some such words as these, if we ponder them well, that we shall find the ultimate basis, and the final expression, of the beliefs which enable us to live.

It was in this attempt to find new expressions for things that "fit one into another in some way" that Morris turned his hand and energies to the lyrics and poetic narratives of his last three decades. 


\section{appendix}

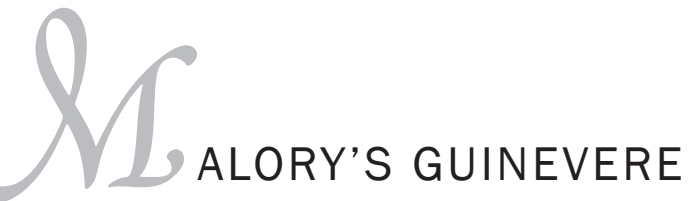

\section{AND MORRIS'S GUENEVERE}

sis reveal his different purposes.

The Malorian originals of Guenevere, Launcelot, and Arthur appeared in Malory's “The Book of Sir Launcelot and Queen Guinevere" (books 18 and 19) and "The Most Piteous Tale of the Morte Arthur Sans Guerdon" (books 20-22), and many of the ambiguities in "The Defence" and "King Arthur's Tomb" arguably derive from their Malorian antecedents. In "The Book of Sir Launcelot and Queen Guinevere," Malory described Launcelot's adultery with the Queen, but defended an ideal of fidelity to an extramarital love. In "The Most Piteous Tale of the Morte Arthur," Launcelot repeatedly insisted that Guinevere had been "trew unto my lorde Arthur" (848), ${ }^{1}$ but both lovers also regretted their parts in an affair that had led to the kingdom's downfall.

In "The Book of Sir Launcelot and Queen Guinevere," the language Mal-

1. Citations are from The Works of Thomas Malory, ed. Eugene Vinaver (Oxford: Clarendon, 1954). The relevant incident in "The Most Piteous Tale of the Morte Arthur Sanz Guerdon" occurs in chap. 2, "The Vengeance of Sir Gawain." 
ory employed to characterize Launcelot's and Guinevere's interactions was suggestive but studiously ambiguous:

But ever his thoughtis prevyly were on the quene, and so they loved togydirs more hotter than they ded toforehonde, and had many such prevy draughtis togydir that many in the courte spake of hit; and in especiall sir Aggravayne.... (“The Poisoned Apple") ${ }^{2}$

Malory's account of Arthur's kingdom also included an immense variety of tales Morris omitted, whose cumulative effect was to embed Launcelot and Guinevere's interactions within a network of complex political and social rivalries. Malory's Arthur and Guinevere were originally and fitfully thereafter on good terms, Launcelot and the king had been deeply attached allies, and Gauwayne plots against Launcelot, not from jealousy, but because the latter had slain his three brothers.

In Malory Guinevere's accusers were hot-headed (Gawayne), malicious (Aggravayne), and/or jealous (Mellyagaunce), and the specious charges against Guinevere were that she had plotted to poison Sir Gawayne at a dinner party, and that she had slept with one of her wounded knights, not Launcelot. Nonetheless, Malory seemingly endorsed the proposed sentence of death as egalitarian, for a queen who "sinned" was to be burnt as well as "another poure lady" (752).

Malory's king also approved and derived advantage from Launcelot's role as defender of his queen, and had even urged her to take Launcelot as her champion after the incident of the poisoned apple.

"What aylith you," seyde the kynge, "that ye can nat kepe sir Launcelot uppon youre syde? For wyte you well," seyde the kynge, "who that hathe sir Launcelot uppon his party hath the moste man of worship in thys world upon hys side. Now go youre way," seyde the kynge unto the quene, "and require sir Bors to do batayle for you for Sir Launcelottis sake." (749)

When Launcelot had taken his vow of knighthood and fealty to Arthur, he had also vowed "ever to be [Guinevere's] knight in rhygtht othir in wronge," so that his vindications of Guinevere might be seen as an indirect tribute to Arthur, for he was obligated by his vow to rescue her even when she was "in wronge" (755).

Arthur had also as much need for Launcelot's loyalty as for his wife's. In "The Most Piteous Tale of The Morte Arthur Saunz Guerdon," when he

2. "The Book of Sir Launcelot and Queen Guinevere," chap. 1, “The Poisoned Apple," 744. 
learned that Launcelot had been discovered in Guinevere's chamber, he wasted no time on jealousy but mourned the inevitable dynastic conflict:

"Jesu mercy!" seyde the kynge, "me sore repentith that ever sir Launcelot sholde be ayenste me, for now I am sure that the noble felyshyp of the Rounde Table ys brokyn for ever, for wyth hym woll many a noble knyght holde. And now hit ys fallen so," seyde the kynge, "that I may nat with my worshyp but my quene must suffir dethe," and was sore amoved. (829)

When Launcelot abducted the queen (the act that furnished "The Defence of Guenevere" with its dramatic climax), the king was more grieved at the death of his knights than the loss of Guinevere:

And much more I am soryar for my good knyghtes losse than for the losse of my fayre queen; for quenys I might have inow, but such a felyship of good knyghtes shall nevere be togydirs in no company. (833)

Arthur's statement that "quenys I might have inow" might well have struck nineteenth-century readers as evidence for his "great name and his little love," Guenevere's familiar charge in Morris's poem. Be that as it may, to the end of his life Arthur bitterly regretted the loss of his sometime friend and comrade Launcelot:

... whan kynge Arthur was on horsebak he loked on sir Launcelot; than the teerys braste oute of hys yen, thynknyng of the grete curtesy that was in sir Launcelot more than in ony other man. (840)

And as Sir Gawayne lay wounded in his arms, Arthur declared that

[f]or now, my nevew, sir Gawayne, I woll discover me unto you, that in youre person and in sir Launcelot I moste had my joy and myne affyance. And now have I loste my joy of you bothe, wherefore all myne erthely joy ys gone fro me! (862-63)

Launcelot, in turn, places fealty to Arthur above that to Guinevere; because she had been wrongly accused he had abducted Guinevere in order to 'save' her, but he

3. Book 20, "The Most Piteous Tale of The Morte Arthur Saunz Guerdon," chapter 1, "Slander and Strife." 
... woll be a thousandefolde moe gladder to brynge her agayne than ever I was of her takyng away, wyth thys I may be sure to come sauff and go sauff, and that the quene shall have her lyberté... . (842)

He also sought rapprochement with Arthur again and again, and refrained from defending himself against his sovereign at the risk of his own life and those of his followers.

Guinevere had fled with Launcelot only when about to be burned at the stake, in this case, an execution ordered with Arthur's complicity. When Launcelot had been discovered in her chamber, she had correctly predicted that

... ye ar lykly to be slayne, and then shall I be brente! For and ye myght ascape them ... I wolde nat doute but that ye wolde rescowe me in what daunger that I ever stood in. (822)

She then anticipates the rescue described in Morris's poem: "[I]f ye se that as to-morne they woll putte me unto dethe, than may ye rescowe me as ye thynke best" (824). Nor was there any evidence that Guinevere preferred life in Joyous Guard to residence with Arthur, and when granted amnesty she exhibits no reluctance to return to Arthur and her role as queen.

Malory's aim, in short, was to record a tragedy driven by 'reasons of state' in which sexual passion played a secondary role. Arthur, Guinevere, and Launcelot had loved and esteemed each other, and all desired the good of the kingdom that fate and competing alliances had obliged them to destroy. In Malory's account Guinevere's farewell to Launcelot, delivered in a tone that was firm, dignified, and without rancor, reflected her considered regret for the passing of all of Arthur's Round Table, and Launcelot's final arch-foe, Gawayne, died with a homage on his lips for the man who had defeated him:

... I was hurte to the dethe, whych wounde was fyrste gyffyn of thyn honde, sir Launcelot; for of a more nobelar man myght I nat be slayne. (863)

As for adultery, Malory's narrator was ambiguous or silent on the subject, with the exception of one well-known incident, guirlanded with a lyric 'defense' that anticipated Morris's Defence:

Therefore, lyke as May moneth flowryth and floryshyth in every mannes gardyne, so in lyke wyse lat every man of worshyp florysh hys herte in thys worlde: firste unto God, and nexte unto the joy of them that he promysed hys feythe unto; for there was never worshypfull man nor worshypfull 
woman but they loved one bettir than another; and worshyp in armys may never be foyled. But firste reserve the honoure to God, and secundely thy quarell muste com of thy lady. And such love I calle vertuouse love. ("The Book of Sir Launcelot," 791)

Essential to such "vertuouse [Latin: "manly"] love" was a "stabylyté," which Malory situated in a better if counterfactual time, and it was in this context that he introduced Guinevere as a "trew lover" who "therefore ... had a good end."

And ryght so faryth the love nowadayes, sone hote sone colde. . . But the olde love was nat so. For men and women coude love togydirs seven yerys, and no lycoures lustis was betwyxte them, and than was love, trouthe and faythefulnes. And so in lyke wyse was used such love in kynge Arthurs dayes. ("Sir Launcelot," 791)

These judgments also preceded directly the accounts of Launcelot's rescue of Guinevere from Mellyagaunce, Launcelot and Guinevere's assignation, and the ill-fated discovery of the queen's blood-stained bedsheets. Malory's one explicit instance of queenly adultery thus appeared in pointed contrast to "lycoures lustis," and the indirection of its amused description bore his seal of courtly approval:

So, to passe upon thys tale, sir Launcelot wente to bedde with the quene and toke no force of ys hurte honde, but toke hys plesaunce and hys lykynge untyll hit was the dawning of the day; for wyte you well he slept nat, but wacched. ("Sir Launcelot," 801)

After Launcelot returned to his quarters at dawn, more precisely at "nine of the clok," Mellyagaunce came into the Queen's bedchamber unannounced and ripped open her bed-curtains without warning.

Mellyagaunce had already kidnapped Guinevere with the intention of raping her, before he surrendered in prostrate fear upon Launcelot's arrival. The wonder is that anyone in Guinevere's or Arthur's court heeded or responded to Mellyagaunce's charge at all. In Malory's duel-mad world, Mellyagaunce quickly proclaimed his charge, but in his haste he had mistaken the identity of Guinevere's lover, so Launcelot could answer with a clear conscience:

'Thus I say', seyde sir Mellyagaunce, 'here ys my glove that she ys a traytoures unto my lorde kynge Arthur, and thys nyght one of the wounded knyghtes lay with her.' 
'Well, sir, and I resceyve youre glove,' seyde sir Launcelot. (“Sir Launcelot," 803)

In "The Most Piteous Tale of the Morte Arthur Saunz Guerdon," by contrast, Malory's narrator seemed to tergiversate about what happened in Guinevere's bedchamber:

For, as the Freynshhe booke seyth, the quene and sir Launcelot were togydirs. And whether they were abed other at other maner of disportis, me lyste nat thereof make no mencion, for love that tyme was nat as love ys nowadays. (“The Most Piteous Tale," 821)

"That tyme," of course, is also the time of the preceding incident of the bedchamber, but here the narrator seems to credit the protagonists' restraint. Moreover, Launcelot seems sincere when throughout "The Most Piteous Tale" he defends the Queen as "trew ... unto [Arthur's] person":

... there nys no knyght undir hevyn that dare make hit good uppon me that ever I was traytour unto youre person ... my lady, quene Guenvyer, ys as trew a lady unto youre person as ys ony lady lyvyng unto her lorde ... (836-37)

... I here myselff, sir Launcelot du Lake, woll make hit good upon hys body that she ys a trew lady unto you. (844)

'Now lat se whatsomever he be in thys place that dare sey the quene ys nat trew unto my lorde Arthur, lat se who woll speke and he dare speke.' (848)

And similarly with Launcelot's abduction of the queen:

'Sir, hit was never in my thought ... to withholde the quene frome my lorde Arthur, but I kepe her for thys cause: insomuch as she shulde have be brente for my sake, mesemed hit was my parte to save her lyff and put her from that daunger tyll bettir recover myght com. (842)

Legalistic attempts to reconcile the equivocations of Malory's Guineveres and Launcelots in these and other passages are available, but they seem to me to miss the point. Malory's characters knew the facts, and were constrained by an arbitrary law to identify adultery with 'treason.' But for simple decency, 
and in this case benign 'reasons of state', they wanted to uphold a defensible sense in which Guinevere was otherwise 'loyal' to her husband.

Malory's division of the ethical house thus left Morris with two alternate interpretations of Guenevere's behavior. Critics have agreed since the appearance of Laurence Perrine's 1960 article that Morris's Guenevere, like her antecedent in book 19 of Le Morte d'Arthur, committed adultery. But Morris seemed to derive other aspects of Guenevere's character and sensibility from Malory's 'other' Guinevere-an upright consort, who was also Launcelot's faithful lover-in-spirit and on at least one occasion in fact, but who deeply regretted the exaggerated consequences of their natural and essentially harmless attachment. The queen's final farewell to Launcelot suggests both responses:

'Thorow thys same man and me hath all thys warre be wrought, and the deth of the moste nobelest knyghtes of the worlde; for thorow oure love that we have loved togydir ys my moste noble lorde slayne. . . And to thy kyngedom loke thou turne agayne, ... for as well as I have loved the heretofore, myne [har]te woll nat serve now to se the; for thorow the and me ys the f[lour]re of kyngis and [knyghtes] destroyed. (876)

Morris's recapitulation of Malory's studious ambiguation was therefore deliberate, I believe. He wished to celebrate the value of sensual love and to defend a wronged woman, and neither he nor Malory wished to confine the ethics of marital and extramarital attachments to a procrustean bed. 


\section{WORKS IN ENGLISH PROBABLY READ BY MORRIS BEFORE 1870} (SOURCES FOR HIS WRITINGS)

Baring-Gould, Sabine. Curious Myths of the Middle Ages. London, Cambridge, and Oxford: Rivington, 1866 (2nd expanded ed. 1868).

Boccaccio, Giovanni. The Decameron. London: Gibbings, 1896.

Bollandus, Joannes and Henscheim, Godefridus. Acta Sanctorum. . . Paris: V. Palme, 1863. Tom. 5 .

Borrow, George. Lavengro: The Scholar, The Gipsy, the Priest. 3 vols. London: John Murray, 1851. Browning, Elizabeth Barrett. Poems. London: Edward Moxon, 1844.

Browning, Robert. Men and Women. 2 vols. Chapman and Hall: London, 1855.

- Poems. 2 vols. London: Chapman and Hall, 1849.

Carlyle, Thomas. On Heroes and Hero Worship. London: Chapman and Hall, 1841.

—. Past and Present. London: Chapman and Hall, 1843.

—. Sartor Resartus. 2nd ed. London: Fraser, 1841.

-, trans. German Romance: Specimens of Its Chief Authors. 2 vols. London: Chapman and Hall, 1843.

Musaeus, Johann August. "Libuessa," in vol. 1, 86-134. Tieck, Ludwig. "The Fair-Haired Eckbert," "The Trusty Eckart," “The Runnenberg," “The Elves," in vol. 1, 269-87, 288-318, 319-42, 343-64.

Caxton, William, trans. The Recuyell of the Historyes of Troy. Written in French by Raoul Lefevre, edited by H. Oskar Sommer. vol. 1. London: Nutt, 1894.

Chaucer, Geoffrey. The Poetical Works of Geoffrey Chaucer. London: Edward Moxon, 1843.

Church of England. The Book of Common Prayer, and Administration of the Sacraments. . . London: Eyre and Spottiswoode, [c. 1840]. 
Cobbett, William. A History of the Protestant "Reformation," in England and Ireland; Showing How That Event Has Impoverished and Degraded the Main Body of the People in Those Countries. London: Charles Clement, 1824-26.

—. Rural Rides. Edited by Pitt Cobbett. 2 vols. London, 1830.

Commynes, Philip de. The Historical Memoirs of Philip de Commynes: Containing the Transactions of Lewis XI and of Charles VII of France and of Edward IX and Henry VII of England. London: W. McCowall, 1817.

Dasent, George. Popular Tales from the Norse. Edinburgh: Edmonston and Douglass, 1854. (Translations from the Norske folkeventyr collected by MM. Asbjornsen and Moe.)

De Voragine, Jacobus. The Golden Legend; or, Lives of the Saints, as Englished by William Caxton. Introduction by F. S. Ellis. 7 vols. London: J. M. Dent, 1900.

Dickens, Charles. By 1870, Morris would have read Sketches by "Boz" (1836); Pickwick Papers (1837); Oliver Twist (1838); Nicholas Nickleby (1839); The Old Curiosity Shop (1841); Barnaby Rudge (1841); Master Humphrey's Clock (1841); David Copperfield (1850); American Notes (1842); A Christmas Carol (1843); Martin Chuzzelwit (1843); The Cricket on the Hearth (1845); Dombey and Son (1848); A Child's History of England (1851-53); Bleak House (1852); Hard Times (1854); Little Dorritt (1857); A Tale of Two Cities (1859); Great Expectations (1861); Our Mutual Friend (1865). Morris also enjoyed two tales from Household Words: "Alice and the Angel," vol. 3, no. 53, 1851, 1-9, and "Colonel Quagg's Conversion," vol. 10, no. 20, 1855, 459-65.

Digby, Kenelm. The Broad Stone of Honor; or, Rule for the Gentlemen of England. London, 1822.

—. Mores Catholici; or, Ages of Faith. 3 vols. London: C. Colman, 1845-47.

Dobell, Sydney. England in Time of War. London: Smith, Elder, 1856.

- The Roman. London: Smith, Elder, 1854.

Froissart, Jean. The Chronicles of England, France, Spain, and the adjoining Countries. . . Translated by Thomas Johnes. 2 vols. London: Smith, Elder, 1839.

Gerard, John. Gerard's Herball the Essence Thereof Distilled by Marcus Woodward from the Edition of Thomas Johnson. 1636; London: Gerard Howe, 1927.

Gibbon, Edward. The History of the Decline and Fall of the Roman Empire. With notes by H. H. Milman. 6 vols. Boston: Phillips, Sampson, 1852.

Grimm, Jacob and Wilhelm Grimm. German Popular Stories. Translated by Edgar Taylor from the Kinder und Haus Marchen, collected by M. G. from the oral tradition. 2 vols. London: C. Baldwin, 1823 .

Hallam, Henry. View of the State of Europe during the Middle Ages. London: J. Murray, 1818.

Hawthorne, Nathaniel. The Scarlet Letter, A Romance. Boston: Ticknor, 1854.

—. Twice Told Tales. 2 vols. Boston: Ticknor, 1851.

Hood, Thomas. Poems of Wit and Humour. London: Edward Moxon, 1844.

Irving, Washington. A History of the Life and Voyages of Christopher Columbus. 4 vols. London, 1828.

Keats, John. The Poetical Works of John Keats. London: William Smith, 1840.

Kingsley, Charles. Alton Locke, Tailor and Poet, An Autobiography. 2 vols. London: Chapman and Hall, 1850.

- Andromeda, and Other Poems. Boston: Ticknor and Fields, 1858.

The Heroes; or, Greek Fairy Tales. 2nd edition. Cambridge and London: Macmillan, 1859. 
- Hypatia: or, New Foes with an Old Face. Repr. from Fraser's Magazine. 2 vols. London, 1853.

. The Saint's Tragedy; or, The True Story of Elizabeth of Hungary. London: Parker, 1848.

. Two Years Ago. 3 vols. Cambridge: Macmillan, 1857.

- Westward Ho! or, The Voyages and Adventures of Sir Amyas Leigh, Knight of Burrough, in the County of Devon, in the Reign of Her Most Glorious Majesty Queen Elizabeth. London: Macmillan, 1855.

- Yeast: A Problem. London: Parker, 1851.

Laing, Samuel, trans. and ed. Heimskringla; or, Chronicles of the Kings of Norway. 3 vols. London, 1841.

La Motte-Fouqué, Friedrich de. “Aslauga’s Knight.” In German Romance, translated by Thomas Carlyle, 2:284-387.

- Minstrel Love: A Romance. From the German. A new translation. London, 1845.

The Seasons: Four Romances from the German. London, 1843.

- Thiodulf the Icelander. London: J Burns, 1845.

- Undine, and Sintram and His Companions. Translated by T. Tracy. New York: George Putnam, 1850.

Wild Love and Other Tales, from the German. London, 1844.

Lane, Edward W., trans. The Arabian Nights Entertainment. 3 vols. London: C. Knight, 1841.

Lemprière, John. A Classical Dictionary. . . . A new edition. Revised Rev. T. Smith. London: T. Allman, 1847.

Lytton, Edward Robert Bulwer. Clytemnestra, The Earl's Return, The Artist, and Other Poems, by Owen Meredith. London: Chapman and Hall, 1855.

Macdonald, George. Within and Without. London, 1855.

Madden, Frederic, ed. Gesta Romanorum. London: Roxburghe Club, 1838.

Mallet, M. Paul. Northern Antiquities: or, A Description of the Manners, Customs, Religion, and Laws of the Ancient Danes, and other Northern Nations. . . Translated from the French of M. Paul H. Mallet by Bishop Percy. New ed. Revised by J. A. Blackwell. London: Bohn's Antiquarian Library, 1847.

Malory, Thomas. The Byrth, Lyf, and Actes of King Arthur . . . Introduction by Robert Southey. 2 vols. London: Longman, 1817.

Mandeville, John. The Voiage and Travaile of Sir John Maundeville. Edited by J. O. Halliwell. London: E. Lumley, 1839; London: F. S. Ellis, 1866.

Marryat, Frederick. Mr. Midshipman Easy. London: Richard Bentley, 1838.

- Peter Simple. Leipzig: Tauchnitz, 1842.

Meinhold, Wilhelm. Sidonia the Sorceress, The Supposed Destroyer of the Whole Reigning Ducal House of Pomerania. Translated by Lady Wilde. Mary Schweidler, The Amber Witch. London: Reeves and Turner, 1894.

Milman, Henry Hart. History of Latin Christianity; Including That of the Popes to the Pontificate of Nicholas V. 6 vols. London: John Murray, 1854-55.

Milton, John. The Poems of John Milton. With notes by T. Keightley. 2 vols. London: Chapman and Hall, 1859 . 
Monstrelet, Enguerrand de. The Chronicles of Enguerrand de Monstrelet. Translated by T. Johnes. 2 vols. London: William Smith, 1845.

Neale, John Mason. A History of the Holy Eastern Church. 5 vols. London, 1850, 1851, 1847, 1873.

Nelson, Robert. A Companion for the Festivals and Fasts of the Church of England. . . London: A. and J. Church, 1705.

Percy, Thomas, ed. Reliques of Ancient English Poetry. . . London: J. Dodsley, 1765.

Poe, Edgar Allan. The Poetical Works of Edgar Allan Poe, with a Notice of His Life and Genius by James Hannay, esq. London: Addey, 1853.

- Tales and Sketches: To Which Is Added the Raven, a Poem. London, 1852.

Prescott, William H. History of the Conquest of Mexico. London: Richard Bentley, 1850.

- History of the Conquest of Peru. London: Routledge, 1847.

Pugin, A. W. N. Contrasts. London: 1836.

- The True Principles of Pointed or Christian Architecture: Set Forth in Two Lectures Delivered at St. Marie's, Oscott. London: Bohn, 1853.

Reeve, Clara. The Old English Baron. London: Charles Dilly, 1780.

Ritchie, Leitch. Liber Fluviorum; or River Scenery of France. Depicted in Sixty-One Line Engravings from Drawings by J. M. W. Turner. London, H. G. Bohn, 1853.

Rossetti, D. G. The Early Italian Poets. London: Smith, Elder, 1861.

Ruskin, John. Lectures on Architecture and Painting Delivered at Edinburgh . . 1853. London: Smith, Elder, and Co., 1854.

- Modern Painters. 3rd ed. 5 vols. London: Smith, Elder, 1846-6o.

_. Pre-Raphaelitism. London: Smith, Elder, 1851.

- The Seven Lamps of Architecture. London: Smith, Elder, 1849.

- Stones of Venice. 3 vols. London: Smith, Elder, 1851-53.

Scott, Walter. The Antiquary. Edinburgh: J. Ballantyne, 1816.

- Minstrelsy of the Scottish Border: consisting of historical and romantic ballads, collected in the southern counties of Scotland; with a few of modern date, founded upon local tradition. 3 vols. Kelso: James Ballantyne, 1802-3.

- The Poetical Works of Sir Walter Scott, Bart. . . . Edinburgh: Robert Cadell, 1841.

- Waverly Novels. 48 vols. Edinburgh and London: Robert Cadell, 1830-34. Morris read all of these; medieval or antiquated settings appear in, among others, Ivanhoe, The Talisman, The Antiquary, Guy Mannering, The Abbot, and The Monastery.

Shakespeare, William. The Dramatic Work of William Shakespeare. London: George Routledge, 1849.

Shelley, P. B. The Works of Percy Bysshe Shelley. Edited by Mrs. Shelley. 2 parts. London: E. Moxon, 1847 .

Sismondi, J. C. L. A History of the Fall of the Roman Empire. 2 vols. London: Longmans, 1834.

Smith, Alexander. A Life Drama and Other Poems. London: D. Bogue, 1853.

Southey, Robert. The Poetical Works of Robert Southey. London: Longman, Hurst, Rees, Orme, and Brown, 1815-21.

Stow, John. Annales, or, a general Chronicle of England; begun by J. Stow . . continued and augmented . . unto the end of . . 1631, by E. Howes. London: R. Meighen, 1631. 
- A Survey of London. Edited by William J. Thoms. London, 1842.

Street, G. B. Brick and Mortar in the Middle Ages. London: J. Murray, 1855.

Stukeley, William. Itinerarium curiosum; or, An account of the antiquities. .. observed in travels through Great Britain. 2nd ed. London: Baker and Leigh, 1776.

Sturleson, Snorre. The Heimskringla; or, The Kings of Norway. Translated by Samuel Laing. 3 vols. London: Longmans, 1844.

Taylor, Henry. Edwin the Fair. London, 1852.

Temple, Neville and Edward Trevor [Julian Fane and Robert Bulwer-Lytton]. Tannhäuser: or, The Battle of the Bards. A Poem. London: Chapman and Hall, 1861.

Tennyson, Alfred. In Memoriam. London: Edward Moxon, 1850.

- Maud. London: Edward Moxon, 1855.

—. Poems. London: Edward Moxon, 1833.

—. Poems. London: Edward Moxon, 1842.

—. Poems, Chiefly Lyrical. London: Effingham Wilson, 1830.

—. The Princess. London: Edward Moxon, 1847.

Thackeray, William M. The Newcomes. Leipzig: Tauchnitz, 1855.

Thorpe, Benjamin. Northern Mythology, Comprising the Principal Popular Traditions and Superstitions of Scandinavia, North Germany, and the Netherlands. 3 vols. London: Edward Lumley, 1851.

_. Yule-tide Stories. A Collection of Scandinavian and North German Popular Tales and Traditions, from the Swedish, Danish, and German. London: Bohn, 1847.

Tracts for the Times. [90 Tracts]. Oxford and London, 1833-41.

Wardle, George. Society for the Protection of Ancient Buildings: A Chapter of Its Early History. London: SPAB, 1899.

Wilberforce, Robert. The Doctrine of Holy Baptism. London: Murray, 1849.

- The Doctrine of the Holy Eucharist. London: Mozley, 1853.

- The Doctrine of the Incarnation of Our Lord Jesus Christ, in Its Relation to Mankind and to the Church. London: Mozley, 1849.

- An Inquiry into the Principles of Church Authority. . . 2nd ed. London: Longman, 1854.

William of Malmesbury. Chronicle of the Kings of England. Edited by J. A. Giles. London: Bohn's Antiquarian Library, 1847.

Yonge, Charlotte M. The Heir of Redclyffe. London: John W. Parker, 1853.

- The Lances of Lynwood. London, 1855.

Periodicals: The Builder; The Germ; The Oxford and Cambridge Magazine.

\section{BIOGRAPHY AND BACKGROUND MATERIAL}

Aho, Gary. William Morris: A Reference Guide. Boston: G. K. Hall, 1985.

Ashley, Maurice and Christopher Thomas Saunders. Red Oxford: A History of the Growth of Socialism in the University of Oxford. Oxford: Holywell Press, 1930. 
Blunt, Wilfred. My Diaries. New York: Knopf, 1932.

Boos, Florence, ed. "Attributions of Authorship in the Oxford and Cambridge Magazine." Notes and Queries 61.4 (November 2014): 561-63.

. "From the Archive: 'Communism-i. e. Property': A Partly Unpublished Morris Essay." William Morris Society-US Newsletter, Summer 2009, 15-21.

- The Juvenilia of William Morris. New York: William Morris Society, 1983.

- Our Country Right or Wrong, by William Morris. London: William Morris Society, 2008.

_. "William Morris's 'Equality': A Critical Edition." Journal of Pre-Raphaelite Studies 20 (Spring 2011): 51-70.

Boos, Florence and Patrick O'Sullivan. "Morris's Socialism and Devon Great Consols." Journal of William Morris Studies 20.1 (2012): 11-39.

Bradley, Ian. William Morris and His World. London: Thames and Hudson, 1978.

Burne-Jones, Georgiana. Memorials of Edward Burne-Jones. 2 vols. London: Macmillan, 1904.

Coles, Dorothy. “'My Dearest Emma': William and Emma Morris." Journal of William Morris Studies 16.1 (2004): 45-60.

Coote, Stephen. William Morris: His Life and Work. New York: Smithmark, 1995.

Darwall-Smith, Robin. A History of University College, Oxford. Oxford: Oxford University Press, 2008.

Dixon, R. W. "Memoir of William Morris by R. W. Dixon." Edited by Florence Boos. William Morris Society-US Newsletter, January 2008, 19-23.

Donovan, Andrea. William Morris and the Society for the Preservation of Ancient Buildings. New York: Routledge, 2007.

Dufty, A. R. Introduction to The Story of Cupid and Pysche, by William Morris. 2 vols. and portfolio. London and Cambridge: Clover Hill Editions, 1974.

Dunlap, Joseph. The Book That Never Was. New York: Oriole Editions, 1971.

Faulkner, Peter. Against the Age: An Introduction to William Morris. London: George Allen and Unwin, 1980.

- William Morris: Early Romances in Prose and Verse. London: J. M. Dent, 1973.

— ed. William Morris: The Critical Heritage. London: Routledge and Kegan Paul, 1973.

Ferry, Emma. “'The Other Miss Faulkner': Lucy Orrinsmith and the 'Art at Home Series.” Journal of William Morris Studies 19.2 (Summer 2011): 47-64.

Fleming, Margaret. "Where Janey Used to Live." Journal of the William Morris Society 4.3 (1981): $2-17$.

Froissart, Jean. The Chronicles of Froissart, ed. Geoffrey Brereton. Harmondsworth: Penguin Books, 1978.

Gardner, Delbert R. An "Idle Singer" and His Audience: A Study of William Morris's Poetic Reputation in England, 1858-1900. The Hague: Mouton, 1975.

Gibeling, Keith. "Peter Paul Marshall: Forgotten Member of the Morris Firm." Journal of the William Morris Society 12.1 (1996): 8-16.

Girouard, Mark. The Return to Camelot: Chivalry and the English Gentleman. New Haven and London: Yale University Press, 1981.

Glasier, Bruce. William Morris and the Early Days of the Socialist Movement. London: Longmans, Green, 1899. 
Goodwin, K. L. A Preliminary Handlist of Manuscripts and Documents of William Morris. London: William Morris Society, 1983.

Grierson, Janet. Isabella Gilmore, Sister to William Morris. London: SPCK, 1962.

Harvey, Charles and Jon Press. Art, Enterprise and Ethics: The Life and Works of William Morris. London: Frank Cass, 1996.

. "The City and Mining Enterprise: The Making of the Morris Family Fortune." Journal of the William Morris Society 9.1 (1990): 3-14.

. William Morris: Design and Enterprise in Victorian Britain. Manchester: University of Manchester Press, 1991.

Henderson, Philip. William Morris: His Life, Work, and Friends. New York: McGraw-Hill, 1967.

- ed. The Letters of William Morris to His Family and Friends. London: Longmans, Green, 1950.

Kelvin, Norman, ed. The Collected Letters of William Morris. Vol. 1, 1848-1880. Vol. 2, 1881-1888. Vol. 3, 1889-1892. Vol. 4, 1893-1896. Princeton: Princeton University Press, 1984, 1987, 1996, 1996.

-William Morris on Art and Socialism. New York: Dover, 1999.

Lago, Mary, and T. C. Rooke, eds. Burne-Jones Talking: His Conversations 1895-98 Preserved by His Studio Assistant Thomas Rooke. Columbia: University of Missouri Press, 1981.

Latham, David and Sheila Latham. An Annotated Critical Bibliography of William Morris. Hempstead: Harvester, 1991.

Le Bourgeois, John Y. Art and Forbidden Fruit: Hidden Passion in the Life of William Morris. London: Lutterworth, 2006.

LeMire, Eugene. A Bibliography of William Morris. New Castle, DE: Oak Knoll, 2006.

. "The 'First' William Morris and the 39 Articles." Journal of the William Morris Society 7.2 (1987): 9-14.

—. Unpublished Lectures of William Morris. Detroit: Wayne State University Press, 1969.

Lethaby, W. R. Philip Webb and His Work. London: Oxford University Press, 1935, new ed. London: Raven Oak Press, 1979.

Lindsay, Jack. William Morris: His Life and Work. London: Constable, 1975; New York: Taplinger, 1979.

MacCarthy, Fiona. The Last Pre-Raphaelite: Edward Burne-Jones and the Victorian Imagination. Cambridge, MA: Harvard University Press, 2011.

"William Morris." Oxford Dictionary of National Biography, Oxford University Press, 2004. Online ed., October 2009. http://www.oxforddnb.com, article 19322

. William Morris: A Life for Our Time. London: Faber and Faber, 1994.

Mackail, J[ohn] W. The Life of William Morris. 2 vols. London: Longmans, Green, 1899.

- William Morris and His Circle. Oxford: Clarendon, 1907.

Malory, Thomas. The Works of Sir Thomas Malory, ed. Eugene Vinaver. London: Oxford University Press, 1962.

Marsh, Jan. Dante Gabriel Rossetti: Painter and Poet. London: Weidenfeld and Nicholson, 1999. - "Knight and Angels: The Treatment of 'Sir Galahad' in the Works of Gabriel Rossetti, Elizabeth Siddal and William Morris." Journal of the William Morris Society 8.1 (1988): 14-23.

—. Jane and May Morris: A Biographical Story, 1839-1938. London, 1986, 2000. 
“La Belle Iseult." Journal of William Morris Studies 19.2 (2011): 9-19.

William Morris and Red House: A Collaboration Between Architect and Owner. London: National Trust Books, 2005.

McCrimmon, Barbara. Richard Garnett: The Scholar as Librarian. Chicago: American Library Association, 1989.

Morris, May, ed. William Morris: Artist, Writer, Socialist. 2 vols. Oxford: Blackwell, 1936; rpt. 1966.

Morris, William. The Collected Works of William Morris. Edited by May Morris. 24 vols. London: Longmans, 1910-15.

—. Gothic Architecture. London: Kelmscott Press, 1893.

—. Three Works by William Morris, ed. A.L. Morton. London: Lawrence and Wishart, 1986.

Parkins, Wendy. Jane Morris: The Burden of History. Edinburgh: Edinburgh University Press, 2013.

Pinkney, Tony. William Morris in Oxford: The Campaigning Years, 1879-1895. Grosmont, South Wales: Illuminati, 2007.

— Books, 2005 .

Price, Lorraine. “Cormell Price, Esq., The Tower, Broadway.” William Morris Society Journal 5.4 (1983/84): 30-39.

—_. "Kipling's Friendship with Cormell Price-Part One." Kipling Journal, 68 (No. 269, March 1994): 11-21; Part Two (No. 270), June 1994: 21-29.

Prinsep, Valentine C. “A Chapter from a Painter's Reminiscence: The Oxford Circle: Rossetti, Burne-Jones and William Morris." Magazine of Art 27, n.s. 2 (1904): 167-71.

Purkis, John. Morris, Burne-Jones and French Gothic: Being an Account of a Walking Tour in France July to August 1855. London: William Morris Society, 1988; rpt. 1991.

Salmon, Nicholas. "A Friendship from Heaven: Burne-Jones and William Morris." Journal of William Morris Studies 13.1 (1998): 2-13.

Salmon, Nicholas and Derek Baker. The William Morris Chronology. Bristol: Thommes, 1996.

Sambrook, James. A Poet Hidden: The Life of Richard Watson Dixon, 1833-19oo. London: Athlone, 1962.

Sharp, Frank C. "Isabella Morris Gilmore." Journal of the William Morris Society 11.4 (1996): $31-38$.

Simpson, Roger. "In Defence of William Fulford." Journal of Pre-Raphaelite Studies 2 (1993): 2127.

__. "William Fulford: An Arthurian Reclaimed." Quondam et Futurus 1.1 (1991): 56-72.

—. "William Fulford: A Biographical Sketch." Review of the Pre-Raphaelite Society 1.3 (Autumn 1993): 1-14.

. "William Fulford Revisited." Review of the Pre-Raphaelite Society 5.1 (Spring 1997): 13-20.

Stokes, E. E. Jr. “The Morris Letters at Texas.” Journal of the William Morris Society 1.3 (1963): $23-30$.

Stansky, Peter. William Morris. Oxford: Oxford University Press, 1983.

Taylor, David. “Vernon Lushington, Practicing Positivism.” Diss., University of Roehampton, 2008. 
Tennyson, Alfred. The Poems of Alfred Tennyson, ed. Christopher Ricks. London: Longmans, 1969.

Thompson, Edward P. William Morris, Romantic to Revolutionary. London: Lawrence and Wishart, 1955. 2nd ed., with an afterword. New York: Pantheon, 1977.

Whyte, William. "Charles Faulkner." Oxford Dictionary of National Biography. Oxford University Press, 2004-14, article 75608.

\section{EDITIONS AT THE WILLIAM MORRIS ARCHIVE}

Early poems: http://morrisedition.lib.uiowa.edu/earlypoems.html

Early prose romances: http://morrisedition.lib.uiowa.edu/earlyproseromances.html

The Defence of Guenevere: http://morrisedition.lib.uiowa.edu/defenceguenevere.html

Unpublished tales from the Earthly Paradise: http://morrisedition.lib.uiowa.edu/ep.html

"Poems from the Earthly Paradise Period," http://morrisedition.lib.uiowa.edu/ listpoemsepperiod.html

\section{CRITICISM (ITEMS AVAILABLE AT THE WILLIAM MORRIS ARCHIVE ARE FOLLOWED BY AN ASTERISK)}

Armstrong, Isobel. “A New Radical Aesthetic, The Grotesque as Cultural Critique: Morris." Victorian Poetry: Poetry, Politics, and Politics. London: Routledge, 1993. 227-46.

Arscott, Caroline. William Morris and Edward Burne-Jones: Interlacings. New Haven: Yale University Press, 2008.

Baïssus, Jean-Marie. "Morris and the Oxford and Cambridge Magazine." Journal of the William Morris Society 5.2 (Winter 1982): 2-13.*

William Morris, Poète. 3 tom. Lille: Université de Lille, 1980.

Baker, Lesley. "The Earthly Paradise of Morris and Burne-Jones." Journal of the William Morris Society 5.1 (1982): 25-30.*

Balch, Dennis R. "Guenevere's Fidelity to Arthur in 'The Defence of Guenevere' and 'King Arthur's Tomb." Victorian Poetry 13.3-4 (1975): 61-70.*

Benjamin, Walter. "Theses on the Philosophy of History." In Illuminations, translated by Harry Zohn. New York: Schocken Books, 1968. 253-64.

Bennett, Phillippa. "Riot, Romance and Revolution: William Morris and the Art of War." Journal of William Morris Studies 18.4 (2010): 22-35.*

Berry, Ralph. “A Defense of Guenevere.” Victorian Poetry 9 (1971): 277-86.*

. "The Symbolism of William Morris." Journal of the William Morris Society 3.4 (Winter 1978): $20-34 .^{*}$

Bledsoe, Audrey. “The Seasons of Camelot," South Atlantic Bulletin 42 (1977): 114-22.

Bloch, Ernst. Das Prinzip Hoffnung. 3 vols. 1938-47; Cambridge, MA: MIT Press, 1968.

Boos, Florence S. “Class and the 'Spasmodics': W. E. Aytoun, George Gilfillan, Sydney Dobell, and Alexander Smith." Victorian Poetry 42.5 (2005): 553-83. 
The Design of William Morris's “The Earthly Paradise.” New York: Mellen, 1991.

“The Evolution of 'The Wanderers Prologue."” Papers on Language and Literature 20 (1984): 397-417.*

. "A Holy Warfare Against the Age': Essays and Tales in The Oxford and Cambridge Magazine." Victorian Periodicals Review 46 (2014): 344-68.*

- "Justice and Vindication in William Morris's The Defence of Guenevere." King Arthur Through the Ages, eds. Valerie Lagorio and Mildred Leake Day. Vol. 2. New York: Garland, 1990, 83-104.*

. "Sexual Polarities in William Morris's The Defence of Guenevere." Browning Institute Studies 13 (1985): 181-200.*

—. Socialist Aesthetics and "The Shadows of Amiens." London: William Morris Society, 2011.

- "The Sources of Morris's 'The Wanderers' Prologue." American Notes and Queries 22 (1984): $73-78 .^{*}$

. “'The Story of Orpheus and Eurydice': An Omitted Earthly Paradise Tale." Journal of PreRaphaelite Studies 4.1 (1983): 59-86.*

- "The Structure of Morris's Tales for the Oxford and Cambridge Magazine." Victorian Periodicals Review 20 (1987): 2-12.*

“Ten Journeys to the Venusberg: William Morris's Drafts for 'The Hill of Venus." Victorian Poetry 39.4 (2002): 597-615.*

"William Morris, Robert Bulwer-Lytton, and the Arthurian Poetry of the 1850s." Arthuriana 6.3 (Fall 1996): 30-51.*

— ed. The Earthly Paradise by William Morris. 2 vols. New York: Routledge, 2002.

Braesel, Michaela. "The Influence of Medieval Illuminated Manuscripts on the Pre-Raphaelites and the Early Poetry of William Morris." Journal of William Morris Studies 15.4 (2004): 41$54 .^{*}$

Braudy, Leo and Marshall Cohen. Film Theory and Criticism: Introductory Readings. Oxford: Oxford University Press, 1999.

Butler, Judith. Gender Trouble. New York: Routledge, 1990.

Calhoun, Blue. The Pastoral Vision of William Morris. Athens: University of Georgia Press, 1974.

Carson, Mother Angela. “Morris's Guenevere: A Further Note.” Philological Quarterly 42 (1963): $131-34 .^{*}$

Chen, Karl C. "A Study of the Sources and Influences upon William Morris's 'The Defence of Guenevere and Other Poems.” Diss., Yale University, 1934.

Dahl, Curtis. “Morris's 'The Chapel in Lyoness': An Interpretation.” Studies in Philology 51 (1954): $482-91 .^{*}$

Darling, Michael. "Robert Bulwer-Lytton.” In Victorian Poets Before 1850. Dictionary of Literary Biography, vol. 32, edited by William E. Fredeman and Ira Nadel. Detroit, MI: Gale, 1984. 202-8.

Davies, Frank. “William Morris's 'Sir Peter Harpdon's End.” Philological Quarterly 11 (1932): $314-17 .^{*}$

Deal, Kenneth. "Acts of Completion: William Morris's Early Prose Romances." In The Golden Chain: Essays on William Morris and Pre-Raphaelitism, edited by Carole Silver. New York: William Morris Society, 1981. 53-74.* 
Dewan, Pauline. "Patterns of Enclosure in Morris's Early Stories." Journal of the William Morris Society 11.2 (Spring 1995): 9-11.*

Dilthey, Wilhelm. Poetry and Experience. Edited by Rudolf Makkreel and Frithjof Rodi. Vol. 7 of Collected Works.. Princeton: Princeton University Press, 1985.

—. Selected Works. Vol. 5, Poetry and Experience. Princeton: Princeton University Press, 1996.

. "The Understanding of Other Persons and Their Life Expressions." In Theories of History, ed. Patrick Gardiner. New York: Free Press, 1960. 211-24.

Eisenbaum, Boris. "The Theory of the Formal Method." Norton Anthology of Theory and Criticism, ed. Vincent B. Leitch. New York: Norton, 2001.

Evans, B. Ifor. English Poetry in the Later Nineteenth Century. London: Methuen, 1933.

Faulkner, Peter. "Morris and Pre-Raphaelitism." Journal of William Morris Studies 19.4 (Summer 2012), 40-62.*

__. "Morris and Swinburne." Journal of William Morris Studies 15.3 (2003): 4-25.*

__. "Morris and Tennyson." Journal of William Morris Studies 18.2 (2009): 15-44.*

__. "Ruskin and Morris." Journal of William Morris Studies 14.1 (2000): 6-17.*

_. "William Morris and Robert Browning." Journal of William Morris Studies 20.3 (2013): $13-30 .^{*}$

Fletcher, Chris. "A Rediscovered and Partly Unpublished Morris Notebook." Journal of the William Morris Society 14.3 (Winter 2001): 12-20.*

Ford, George F. "William Morris and His Masters." In Keats and the Victorians: A Study of His Influence and Rise to Fame, 1821-1895. New Haven: Yale University Press, 1945.

Frith, Richard. "In Defence of Yseult: Swinburne's Queen Yseult and William Morris." Journal of William Morris Studies 18.1 (2008): 85-95.*

Frye, Northrop. "The Meeting of Past and Future in William Morris." Studies in Romanticism 21 (1982): $303-18 .^{*}$

Gibson, Mary Ellen. History and the Prism of Art: Browning's Poetic Experiments. Columbus: The Ohio State University Press, 1987.

Goodlad, Lauren M. E. and Andrea Sartori, “The Ends of History: An Introduction." Victorian Studies 55.4 (Summer 2013): 591-614.*

Goodwin, K. L. "An Unpublished Tale from The Earthly Paradise." Victorian Poetry 13.3-4 (1975): 91-102. ["The Story of Dorothea"]

Gordon, Walter K. “A Critical Selected Edition of William Morris's 'Oxford and Cambridge Magazine' (1856)." Diss., University of Pennsylvania, 1960.

__. "Pre-Raphaelitism and the 'Oxford and Cambridge Magazine." Rutgers University Library Journal 29 (1966): 42-51.*

Grennan, Margaret. William Morris: Medievalist and Revolutionary. New York: King's Crown, $1945 .^{*}$

Hanson, Ingrid. “'The Measured Music of Our Meeting Swords': William Morris's Early Romances and the Transformative Touch of Violence." Review of English Studies, n.s. 61.250 (2010): 435-54.

- William Morris and the Uses of Violence. London: Anthem, 2013.

Hassett, Constance W. "The Style of Evasion: William Morris's The Defence of Guenevere, and Other Poems." Victorian Poetry 29 (1991): 99-114.* 
Haywood, Andrew. "Morris and Early Music: The Shaw/Dolmetsch Connection." Journal of the William Morris Society 10.4 (1994): 13-19.*

Helsinger, Elizabeth. "Lyric Colour: Pre-Raphaelite Art and Morris's The Defence of Guenevere." Journal of William Morris Studies 15.4 (2004): 16-40.*

—. Poetry and the Pre-Raphaelite Arts. New Haven: Yale University Press, 2008.

Herbert, Karen. "Dissident Language in The Defence of Guenevere." Victorian Poetry 34.3 (1996): $313-27 . *$

Hodgson, Amanda. "Riding Together: William Morris and Robert Browning." Journal of the William Morris Society 9.4 (1992): 3-7.*

—. The Romances of William Morris. Cambridge: Cambridge University Press, 1987.

Hollow, John. "William Morris and the Judgment of God." PMLA 86 (1971): 446-51.*

. "William Morris's 'The Haystack in the Floods." Victorian Poetry 7 (1969): 353-55.*

Holzman, Michael. “The First Version of 'The Wanderers." Journal of Pre-Raphaelite Studies 3.1 (1982): $91-104 .{ }^{*}$

Hoskins, Robert. "Image and Motif in The Haystack in the Floods." Journal of the William Morris Society 3.2 (Summer 1976): 4-7.*

Hosman, Robert Stahr. "The Germ (1850) and The Oxford and Cambridge Magazine (1856)." Victorian Periodicals Newsletter 4 (April 1969): 36-47.*

—. "The Oxford and Cambridge Magazine." In British Literary Magazines: The Victorian and Edwardian Age, edited by Alvin Sullivan. Westport, CT: Greenwood, 1984. 294-302.*

Hough, Graham. "William Morris." In The Last Romantics. London: Gerald Duckworth, 1947. 83-133.

Jackson, Vanessa Furse. “'Two Red Roses Across the Moon’: Reconsidering Symbolic Implications." Journal of the William Morris Society 12.1 (Autumn 1996): 29-34.*

Jameson, Fredric. "Marxism and Historicism." New Literary History 11.1 (1979): 41-73.

Jauss, Hans Robert. "Literary History as a Challenge to Literary Theory." Norton Anthology of Theory and Criticism, ed. Vincent B. Leitch. New York: Norton, 2001. 1150-64.

Kegel, Charles H. "Medieval Modern Contrasts Used for a Social Purpose in the Work of William Cobbett, Robert Southey, A. Welby Pugin, Thomas Carlyle, John Ruskin, and William Morris." Diss., Michigan State University, 1955.

Kirchhoff, Frederick. “'The Glory and Freshness of a Dream': Arthurian Romances as Reconstructed Childhood." Arthuriana 6.3 (1996): $3-13$. $^{*}$

- "Heroic Disintegration: Morris's Medievalism and the Disappearance of the Self." The Golden Chain, ed. Carole Silver. New York: William Morris Society, 1981.*

_. "Introduction." Studies in the Late Prose Romances. New York: William Morris Society, $1976 .^{*}$

- William Morris. Boston: Twayne, 1972.

William Morris: The Construction of a Male Self, 1856-72. Athens: Ohio University Press, 1990.

Kocmanová, Jessie. “The Aesthetic Opinions of William Morris." Comparative Literature Studies 4 (1967): 409-24.

LaPorte, Charles. "Morris's Compromises: On Victorian Editorial Theory and the Kelmscott Chaucer." In Writing on the Image, edited by David Latham. Toronto: University of Toronto Press, 2007. 209-19.* 
Latham, David. “'A Matter of Craftsmanship': William Morris's Manuscripts." Journal of the William Morris Society 6.3 (1983): 2-11.*

"Paradise Lost: Morris's Re-writing of The Earthly Paradise." Journal of Pre-Raphaelite Studies 1.1, pt. 1 (1987): $67-76 .^{*}$

. Latham, David, ed. "Unpublished Tales of The Earthly Paradise." William Morris Archive, http://morrisedition.lib.uiowa.edu/ep.html.*

Lefebvre, Henri. The Critique of Everyday Life. Vol. 2. Translated by John Moore. London: Verso, 2008. 321-22.

LeMire, Eugene, ed. The Hollow Land and Other Tales from the Oxford and Cambridge Magazine. Bristol: Thommes, 1996.

Levine, Naomi. "Trebled Beauty: William Morris's Terza Rima." Victorian Studies 53.3 (2011): 506-17.

Lewis, C. S. "William Morris." In Rehabilitations and Other Essays. London: Oxford University Press, 1939. 35-56.

Litzenberg, Karl. "William Morris and the Reviews: A Study in the Fame of the Poet." Review of English Studies 12 (1936): 414-28.

__. "William Morris and Scandinavian Literature: A Bibliographical Essay." Scandinavian Studies 13 (1933-35): 93-105.

Lourie, Margaret. The Defence of Guenevere and Other Poems. New York: Garland, 1981.*

MacGann, Jerome. Black Riders: The Visible Language of Modernism. Princeton: Princeton University Press, 1983.

—. Social Values and Poetic Arts. Cambridge, MA: Harvard University Press, 1987.

Mancoff, Debra N. "Problems with the Pattern: William Morris's Arthurian Imagery." Arthuriana 6.3 (1996): $55-68 .^{*}$

Maurer, Oscar. "Some Sources of William Morris's 'The Wanderers.” University of Texas Studies in English 29 (1950): 222-29.*

. "William Morris and Gesta Romanorum." In Studies in Language, Literature, and Culture of the Middle Ages and Later, edited by E. B. Atwood. Austin: University of Texas Press, 1969. $367-81 .{ }^{*}$

Miele, Christopher. “'A Small Knot of Cultivated People': William Morris and Ideologies of Protection." Art Journal 54.2 (1995): 73-79.

Miller, Elizabeth Carolyn. Slow Print: Literary Radicalism and Late Victorian Print Culture. Stanford: Stanford University Press, 2013.

Miles, Rosie. "Binding Men: William Morris's The Defence of Guenvere and the Circulation of Masculine Desire." Private and Public Voices in Victorian Poetry, eds. Sabina Coelsch-Foisner and Hölger Klein. Tübingen: Stauffenberg Verlag, 2000. 89-102.*

Oberg, Charlotte. A Pagan Prophet: William Morris. Charlottesville: University Press of Virginia, 1978.

Omerod, James. The Poetry of William Morris. Folcroft, PA: Folcroft, 1938.

O’Reilly, Shelley. "Identifying William Morris' 'The Gilliflower of Gold.” Victorian Poetry 29.3 (1991): 241-46.*

Pater, Walter. The Renaissance: Studies in Art and Poetry (The 1893 Text), ed. Donald E. Hill. Berkeley: University of California Press, 1980.

Patrick, John M. "Morris and Froissart Again: 'Sir Peter Harpdon's End.” Notes and Queries 6 (1959): 331-33. 
Perrine, Laurence. “Morris's Guenevere: An Interpretation.” Philological Quarterly 39 (1960): 234-41.

Prettejohn, Elizabeth, ed. The Cambridge Companion to the Pre-Raphaelites. Cambridge: Cambridge University Press, 2012.

Raymond, Meredith B. "The Arthurian Group in The Defence of Guenevere and Other Poems." Victorian Poetry 4 (1966): 213-18.*

Riede, David G. “Morris, Modernism and Romance.” English Literary History 51 (1984): 85-106.*

Rosenberg, John, ed. The Genius of John Ruskin. London: George Allen, 1963.

Sadoff, Dianne. "Erotic Murders: Structural and Rhetorical Irony in William Morris's Froissart Poems." Victorian Poetry 13.3-4 (1975): 11-26.*

—. "Imaginative Transformation in William Morris's 'Rapunzel." Victorian Poetry 12 (1974): $153-64 .^{*}$

Saintsbury, George. A Historical Manual of English Prosody. 3 vols. London: Macmillan. 1910. Vol. 3, "From Blake to Mr. Swinburne."

Saltzman, Benjamin. "William Morris's 'Golden Wings' as a Poetic Response to the 'Delicate Sentiment' of Tennyson's 'Mariana.'” Victorian Poetry 49.3 (2011): 285-97.*

Sasso, Eleonora. "La retorica del sogno in William Morris: strutture morfosintattiche tipologie linguistiche." TRADUTTOLOGIA / a. II (n. w.), no. 3, Luglio 2006.

- "'The Road of War' and 'the Path of Peace': William Morris's Representation of Violence." In Gilles Teulié (ed.), "Victorian Representations of War," Cahiers Victoriens et Edouardiens 66 (October 2007), Montpellier: Presses Universitaires de La Méditerranée, 485-98.

Schofield, John. “The Defence of Guenevere and Contemporary Critics.” Journal of the William Morris Society 3.1 (Spring 1974): 27-30.*

Schulte, Edvige. Saggi, Saghe e Utopie Nell'Opera di William Morris. Napoli: Liguori Editore, 1987.

Scott, Dixon. “The First Morris." In Men of Letters. London: Hodder and Stoughton, 1916. 257$306 . *$

Shaw, David W. "Arthurian Ghosts: The Phantom Art of 'The Defence of Guenevere." Victorian Poetry 34.3 (1996): 299-312.*

Short, Clarice. "William Morris and Keats." PMLA 59 (1944): 513-23.*

Silver, Carole G. "'The Defence of Guenevere': A Further Interpretation." Studies in English Literature 9 (1969): 695-702.*

- The Romance of William Morris. Athens: Ohio University Press, 1982.

Skelton, John. The Table-Talk of Shirley. London: Blackwood, 1895.

Skoblow, Jeffrey. Paradise Dislocated: Morris, Politics, Art. Charlottesville: University Press of Virginia, 1993.

. "William Morris." In The Cambridge Companion to the Pre-Raphaelites, edited by Elizabeth Prettejohn. Cambridge: Cambridge University Press, 2012. 196-210.

Spatt, Hartley S. "William Morris and the Uses of the Past." Victorian Poetry 13.3-4 (1975): 1-19.*

Staines, David. "Morris's Treatment of His Medieval Sources in The Defence of Guenevere and Other Poems." Studies in Philology 10 (1973): 439-64.*

Stallman, Robert L. “The Lover's Progress: An Investigation of William Morris's 'The De- 
fence of Guenevere' and "King Arthur's Tomb." Studies in English Literature 15.4 (1975): $663-70$. $^{*}$

. "Rapunzel' Unravelled." Victorian Poetry 7 (1969): 221-32.*

Stevenson, Lionel. "William Morris." In The Pre-Raphaelite Poets. Chapel Hill: University of North Carolina Press, 1972. 123-83.

Struve, Laura. "The Public Life and Private Desires of Women in William Morris's 'Defence of Guenevere." Arthuriana 6.3 (1996): 15-28.*

Symons, Arthur. "William Morris." In Studies in Two Literatures. London: L. Smithers, 1897. 3-11.

Thompson, Paul. The Work of William Morris. New York: Viking, 1967.

Tinker, Chauncey B. "William Morris as Poet." In Essays in Retrospect: Collected Articles and Addresses. New Haven: Yale University Press, 1948. 62-74.

Tompkins, J. M. S. William Morris: An Approach to the Poetry. London: Cecil Woolf, 1984.

Tyzack, Charles. "King Arthur's Tomb: The Versions of D. G. Rossetti and William Morris Compared." Trivium 8 (1973): 127-32.*

Vallence, Aymer. William Morris: His Art, His Writings, and His Public Life. London: George Bell and Sons, 1897.

Vaninskaya, Anna. William Morris and the Idea of Community: Romance, History and Propaganda, 1880-1914. Edinburgh: Edinburgh University Press, 2010.

__ "William Morris's Germania: The Roots of Socialism." In William Morris in the TwentyFirst Century, edited by Phillippa Bennett and Rosie Miles. Oxford; New York: Peter Lang, 2010. 169-92.*

Waithe, Marcus. William Morris's Utopia of Strangers: Victorian Medievalism and the Ideal of Hospitality. Cambridge: D. S. Brewer, 2006.

Ward, Megan. "William Morris's Conditional Moment." Romanticism and Victorianism on the Net 53 , February 2009.*

Weinroth, Michelle and Paul Leduc Browne, eds. To Build a Shadowy Isle of Bliss: William Morris's Radicalism and the Embodiment of Dreams. Montreal and Kingston: McGill-Queen's University Press, 2015.

Wiens, Pamela Bracken. “The Empathetic Vision of William Morris.” Diss., Catholic University of America, 1994.

Wilson, Stella P. "William Morris and France." South Atlantic Quarterly 23 (1924): 242-55.*

Whitla, William. "William Morris's 'The Mosque Rising in the Place of the Temple of Solomon': A Critical Text." Journal of Pre-Raphaelite Studies 9 (2000): 43-82.*

Wright, Peter. "William Morris's 'Scenes from the Fall of Troy." William Morris Archive, http:// morrisedition.lib.uiowa.edu/earlypoemsscenesportal.html (accessed 28 June, 2015).

\section{MANUSCRIPTS}

British Library Add. MSS. 45,298A, 45,298B, 45,299, 45,305, 45,307, 45,308, 45,309, 45,318, 74,255; Fitzwilliam Library FW EP 25; Huntington Library HM6427, HM6434. 
310 \& BIBLIOGRAPHY

\section{REVIEWS (LISTED IN CHRONOLOGICAL ORDER)}

Unsigned notice, Spectator, February 1858, xxxi, 238.

Richard Garnett, unsigned review, Literary Gazette, March 1858, xlii, 226-27.

Unsigned review, Ecclesiastic and Theologian, vol. 20, March 1858, 159-70.

H. F. Chorley, unsigned review, Athenaeum, 3 April 1858, no. 1588, 427-28.

Unsigned review, Tablet, April 1858, xix, 266.

Unsigned review, Saturday Review, 20 November 1858, vi, 506-7.

John Skelton, “Shirley," unsigned review, Fraser's Magazine, June 1860, 814-28.

Joseph Knight, Sunday Times, 9 June 1867, no. 2304, 7.

Walter Pater, Review of The Earthly Paradise, Westminster Review, October, 1868, xc, 300-12. 
"The Abbey and the Palace," 75

“The Aims of Art," 108

"And Then As The Ship Moves Over The Deep," 78, 82

"Anthony," 250

"Art and the Beauty of the Earth," 99-100

"The Art of the People," 103

"The Arts and Crafts of Today," 100

"As This Thin Thread," 261

“The Banners," 76, 83

"The Blackbird," 71

"The Captive" (earlier version of "Riding Together"), 90

“Chants for Socialists," 251

"The Churches of North France: Shadows of Amiens." See "The Shadows of Amiens"

"Dear Friends, I Lay Awake in the Night," 71 "The Deeds of Jason" (draft for The Life and Death of Jason), 274

The Defence of Guenevere, 2, 6, 7, 15, 48, 64, 69-70, 72, 80, 84, 88, 91-94, 96, 110,
$124,126,130,162,190-91,195-230,231$,

$233-48,264,279,282,287-93$

“The Blue Closet," 185, 213, 243

“The Chapel in Lyoness," 94, 96, 110, 161, 203, 237

"Concerning Geffray Teste Noire," $74-75,124,173,212-13,243$

“The Defence of Guenevere," 96, 166-67, $178,182,187-88,201,203,220-22$, 236,287

“The Eve of Crècy," 199, 209

“Father John's War-song," 217

“The Gilliflower of Gold," 208-9

“Golden Wings," 164, 185, 215-16, 233, 243,268

"A Good Knight in Prison," 161, 165, 216

"Hands," 91, 95 (later in "Rapunzel”)

"The Haystack in the Floods," 161, 174, 218, 222, 227-28, 238, 253-54

“In Prison," 110, 216

“The Judgment of God," 175, 199

King Arthur's Tomb," 84n33, 96, 124, 141, 166-67, 179-82, 186-90, 200-201, 203, 222, 225-26, 236, 287 
“The Little Tower," 209-10

"Near Avalon," 243-44

"Praise of My Lady," 7, 217-18

"Rapunzel," 59, 91, 164-65, 167-68, 185, 206-8, 234, 242-43

"Riding Together," 90, 95, 110, 161, 216

"Sir Galahad: A Christmas Mystery," 45, $81,167,179,203,237$

“Sir Giles’ War Song," 171

“Sir Peter Harpdon's End," 6, 84-85, 94, $121,161,164,172-74,183,185,199$, 204-6, 236, 243, 245, 250, 253-55, 285

"Spell-Bound," 180, 216, 243

"Summer Dawn," 93, 110, 179, 216, 245, 285

"The Tune of the Seven Towers" 191-92, 199-200, 213-15, 243

“The Wind," 161, 168, 175, 199, 210-12, 236, 243

“The Doomed Ship," 260

“A Dream," 131, 136-43, 200, 213

A Dream of John Ball, 16, 114, 125-28, 133, $136-37,151,176,282$

"Drowned," 77, 79

The Earthly Paradise, 1-2, 28, 47-48, 60, 68, $85,113,117-18,120-21,125,133,136-37$, $150,160-62,165,171,176,181,247,251$, $253,257,263-65,268,272,274-32$

"Apology," 60, 121

“Atalanta's Race," 281

“The Death of Paris," 166, 253

“The Doom of King Acrisius," 164, 268, 274

“The Golden Apples," 165

“The Hill of Venus," 138, 181, 193, 251, 264, 278-81

"The Land East of the Sun and West of the Moon," 193, 281
“The Lady of the Land," 274, 281

"L’Envoi," 60, 68, 121, 284

“The Lovers of Gudrun," 59, 94, 141, 251

“The Man Born to Be King," 142, 275

"The Man Who Never Laughed Again," 251

"Ogier the Dane," 132-33, 136-37, 181, 193,251

"The Palace East of the Sun and West of the Moon," 274-75

“The Proud King," 274-75

"Pygmalion and the Image," 279

“The Ring Given to Venus," 275

“The Son of Croesus," 274

“The Story of Cupid and Psyche," 251, 274

“The Wanderers," 68, 137, 257, 264-73, 275-76

“The Watching of the Falcon," 274, 275, 279

“The Writing on the Image," 274-75, 279

The Earthly Paradise, drafts and projected tales

“Adrastus," 274

"Amys and Amillion" (reported draft), 276

"The Dolphins and the Lovers" (reported draft), 276

“The Fortunes of Gyges” (reported draft), 276

“The King's Treasure House” (reported draft), 276

“The Story of Aristomenes" (omitted tale), 276,278

"The Story of Dorothea" (omitted tale), $265,274,276$

"The Story of Orpheus and Eurydice" (omitted tale), 276

“The Seven Sleepers" (projected tale), 276 
“The Story of Theseus" (projected tale), 268,276

"The Wooing of Swanhild" (omitted tale), 276

"Fame," 59, 73-74, 135

"The Folk of the Mountain Door," 278

“Frank's Sealed Letter," 28, 110

"From All Other Moving Shadows," 82

“Gertha's Lovers," 59, 131, 141, 144-50

“Hapless Love," 258

“The Hollow Land," 131, 141, 153-58, 209, 243

The House of the Wolfings, 144, 146, 282

Hopes and Fears for Art, 98

"How I Became a Socialist," 11

“In Arthur's House," 250

“The Lesser Arts," 98-99, 102, 105

The Life and Death of Jason, 2, 125, 251, 268, 274,282

“The Long Land," 170

Love is Enough, 48, 125, 136, 161, 250-51, 257

“May Grown A-Cold," 258

"The Midnight Tilt (early draft of "Winter Weather"), 70, 88-89, 106-7

"The Mosque Rising in the Place of the Temple of Solomon," 71, 82-87, 106-7, 109

News from Nowhere, 137, 195

“The Night-Walk," 76

The Pilgrims of Hope, 59, 228, 251, 282
“Pray But One Prayer for Me," 91-93, 95

“The Raven and the King's Daughter," 185

Review of Alfred Rethel, "Death the Avenger, Death the Friend," 112

Review of Robert Browning, Men and Women, 122-24, 162, 170, 210, 250

"Rhyme Slayeth Shame," 258

The Roots of the Mountains, 120, 144, 146

“The Ruined Castle," 78-80

"Sad-Eyed and Soft and Grey," 258, 260

"Scenes from the Fall of Troy," 6, 94, 161, 250, 252-58, 269

“Achilles' Love Letter," 256-57

“The Defiance of the Greeks," 257

"Helen Arming Paris," 253, 255, 257

“Helen's Chamber," 255, 257, 269

“The Shadows of Amiens," 75-76, 116, 124-25, $127,131,147-48,174$

Signs of Change, 98

Sigurd the Volsung, 2, 186, 282

"Svend and His Brethren," 131, 141, 144, 150-53

"The Story of the Unknown Church," 59, 74, $125-26,131-36,138,213$

The Tables Turned, or Nupkins Awakened, 250

“The Three Flowers," 59, 78, 81-82, 135, 209

“'Twas in Church on Palm Sunday," 59, 62, 71

"The Willow and the Red Cliff," 69-71, 76

"Winter Weather," 70, 88, 90, 95. See also "The Midnight Tilt" 
adultery, M.s depiction of, 182-83, 201, 221, 293. See also gender; love; marriage; sexuality; women

Aeschylus, 182, 184

aesthetics, M.s sense of, 41, 106-7, 129; M.s writing on, 112; of photography, 238-39; and politics, 251. See also beauty; style

Amiens Cathedral, 46, 113-22. See also architecture; churches; medievalism; Notre Dame; Rouen; travel

architecture: Gothic, 132; M.s early interest in, 104; mysticism concerning, 107; preservation of, 98,101 ; as repository of memory, 99-100, 105; as symbol of permanence, 121-22. See also art; artisans; churches; medievalism; Society for the Protection of Ancient Buildings

Armstrong, Isobel, 234n7

Arnold, Matthew, 11, 160

art: Browning's views on, 123, 173-75; economics of, 104; as granting immortality, 119-20; and labor, 6o, 175; life of, 65, 67, 107 ; and memory, 135; M.s commitment to, 73, 231; M.'s views on, 99, 123, 173-74; and ordinary people, 12-13, 103; and pleasure, 99-100; and politics, 99, 104, 174; and religion, 5, 98, 109; and transmission of truth, 120-21; Victorian conceptions of, 73. See also architecture; artisans

artisans, M.'s attitude toward, 5, 13, 16, 75-76, 99-100, 102, 117, 119, 125, 129, 131-36, 15152, 157, 173-74, 213. See also architecture; art; churches; labor; medievalism

audiences, for M.s narrators, 68, 135, 137-38, $147-48,158,173,273$. See also narrative

authenticity, in M.'s work, 17, 147-48, 194, 241-42. See also historicism; medievalism

Aytoun, William Edmonstone, 236

Bailey, Philip, 236

Balch, Dennis, 203n17

Ball, John, 16, 29, 114-15, 122, 125-28, 133, 137, $151,176,282$

Baring-Gould, Sabine, 273

beauty: M.s appreciation of, 16-17, 24, 45-46, 61, 102, 108, 115, 118, 121, 212, 219; M.'s depiction of, 126, 144, 158-59, 196, 221, 223-24. See also aesthetics; landscape; nature

Berry, Ralph, 196-98

betrayal, M.s depiction of, 59, 173n35. See also loyalty 
Burne-Jones, Edward, 6, 26, 30, 32, 33, 52, 66, $69,107,109,116,162-63,191,250,279$; art of, 39, 42, 47-48, 276-77; friendship with M., 38-49; health of, 47; humor of, 53; as collaborator with M., 276-77; as influence on M., 67; and the life of art, 65; politics of, 48,56

Burne-Jones, Georgiana (Georgiana Macdonald), 18, 28, 36-37, 38, 39, 41-42, 43, $46-47,48,49,50,58,63,65,67,88,105$, $108,110,258$

Black Death, 113

Blackie, John Stuart, 239

Bloch, Ernst, 13

Blunt, Wilfrid Scawen, 73n11

Brendan, Saint, 265-66

Brereton, Geoffrey, 16

Brotherhood, Oxford, 29-38, 42, 50, 61, 67, $87-88,95,130,232$

Browning, Elizabeth Barrett, 75n15, 171, 239-40n26, 240

Browning, Robert, 109, 160, 162, 187, 193, 212, 221, 229, 232, 234, 236, 242, 245, 249; "Andrea del Sarto," 172; "Childe Roland," 123-24; Dramatic Lyrics, 72; "The Flight of the Duchess," 173; as influence on M., 169-76; Men and Women, 122-24, $162,169,170,175,210,250$; praise of M. by, 171

builders. See architecture; artisans

buildings. See architecture; Society for the Protection of Ancient Buildings

Bulwer-Lytton, Robert, 162, 181-84, 278; Clytemnestra, 181-84, 221; The Earl's Return, 184-86; as influence on M., 184-90, 232

Burden, Jane (Jane Burden Morris), 120, 197

Butler, Judith, 222

Byron, George Gordon, “Don Juan,” 106

Carlyle, Thomas, 8, 11-12, 44, 99, 278

Carr, J. Comyns, 247n 58

Carson, Angela, 202

castles, 80, 137, 156, 164-65, 180, 210; in Edgar Allan Poe's work, 191-92; women in, 185,
207-8, 215-16. See also imprisonment; medievalism

cathedrals. See churches

caves, M.s depiction of, 139, 141-43

Caxton, William, 265

Chaucer, Geoffrey, 284

childhood, of M., 19-20, 23-29

Christ, M.'s depictions of, 84-85

Christianity. See churches; religion

churches: beauty of, 118, 126; construction of, 132-36; M.s interest in, 46, 107, 118, 122, 126; M.'s writings on, 116-18. See also Amiens; architecture; artisans; medievalism; Notre Dame; religion

cities, M.s depiction of, $77-78$

classics, M.s study of, 29

Coleridge, Samuel Taylor, 191; "Rime of the Ancient Mariner," 72

color, M.s use of, 89, 138, 142, 156, 165-66, $169,179,189-90,211,215,226,233,239$, 243-44, 247; and restoration of buildings, 119. See also imagery; style

Commonweal, 54-55

composition, M.s process of, 69-72, 94-95, $264-65,274-80,282$

courage, M.'s depiction of, 155, 160, 199, 219 crafts, M.s interest in, 27, 104. See also art; artisans

criticism, literary, 220-22. See also reception theory; reviews

critics. See reviews

Crusades, 85-86, 91, 134. See also medievalism

Culler, A. Dwight, 172n34

\section{Dahl, Curtis, 94}

De La Motte Fouqué, Friedrich, 232

death: and beauty, 126; as fellowship, 75; finality of, 85; in life, 191-93, 214; M.'s depiction of, $73,77-78,80,85,90-92$, 94-96, 112, 159, 165, 191-92, 209, 212, 227 , 244; in nature, 73 ; visions near, 77,80 
decoration, M. on, 102

defeat. See failure

Dilthey, Wilhelm, 8-11

Divorce Law of 1857,201 . See also marriage; Matrimonial Causes Act

Dixon, Richard Watson, 6, 18, 30, 34, 39, 40, $43,44,50,61-62,69-70,104,105,109$, $110,162-63,181,184-85,246,252$

Dobell, Sydney, 6, 126

Dolmetsch, Arnold, 26

drama, poetic, by M., 94-96. See also forms, poetic

dreams: M.'s experience of, 18, 28, 54, 65, 68, 193; M.'s use of, 77-78, 80, 85, 96, 134-41, $153,156,163,190-91,196,207,209-12$, 217, 238, 243, 251, 260; Poe's use of, 190-91; Tennyson's use of, 163

Dunlap, Joseph, 275n131

Dürer, Albrecht, 112

ecstasy, M.s depiction of, 46. See also dreams education, of M., 22-25, 38-49. See also Marlborough College; Oxford

emotion, M.s depiction of, 60, 196, 198-200, 224, 237, 249. See also empathy; love

empathy: artistic, 10, 17; and history, 10, 123-25; in M.'s works, 73, 113, 133, 148, 249; and reading, 61

enjoyment. See pleasure

epiphanies: experienced by M., 108; in M.'s works, 46, 78, 167

eros. See love; sexuality; Venus

ethics: alleged absence from M.'s poetry, 160-61; M.'s interest in, 2-3, 13, 160, 181-82, 196, 240; sexual, 181-82

failure: M.'s attitude toward, 96, 129; M.'s depiction of, 96, 135, 142, 146, 175, 194, 196-99, 206, 248. See also suffering

faith, secular, 2, 11-12. See also fellowship; religion

Fane, Julian, 278
Faulkner, Charles J., 30, 34, 39, 49-58, 66, 110

Faulkner, Peter, 233, 246-47n58

fellowship, 2, 6, 125, 173n35, 194; lacking in the Defence of Guenevere, 161; in M.'s works, 206; as type of immortality, 126-28. See also Brotherhood; friendship; socialism

feminism, as approach to M.'s work, 222; in M.'s works, 229-30. See also gender; women

fidelity. See loyalty

Firm, The, 39, 50-51, 65, 162, 231

flowers, imagery of in M.'s works, 81-82, 108, 136, 138, 154-55, 208-9. See also gardens; imagery; landscape; nature

forms, poetic: M.s use of, 29, 93, 131, 251-52, 282, 285; Tennyson's experiments in, 163

Fra Angelico, 62

friendship: M.s attitude toward, 51, 68, 231; M.'s experience of, 2, 29-38, 45, 57, 67. See also Brotherhood, Oxford; BurneJones, Edward; Burne-Jones, Georgiana; Faulkner, Charles; fellowship; Price, Cormell; Rossetti, Dante; Webb, Philip

Froissart, Jean, 6, 13, 15-16, 89, 126, 193-94, 203, 213, 227, 232, 238, 269. See also Ball, John; Hundred Years' War; medievalism; sources

gardens, M.'s depiction of, 134, 165, 204, 223, 280. See also flowers; landscapes; nature

Garnett, Richard, 7, 170, 194, 234, 235, 236, 237, 241n36, 242, 245n5o, 248

Gaskell, Elizabeth, 246

gender: in M's work, 195-230; modern critiques of, 222-23; as polarized, 201, 205, 208, 218; in "The Wanderers," 271. See also love; sexuality; women

genre. See forms, poetic

Gibbon, Edward, 13, 145

Gibson, Mary Ellis, 176

Glasier, Bruce, 3-4, 96

Gordon, Walter, 112

gothicism, as influence on M., 80 
Guenevere, 84, 96, 171, 179, 182-90, 218, 220, 224, 229, 287-93; in Malory (Guinevere), 182, 202; performativity of, 222-23; silence of, 224; in Tennyson (Guinevere), 167

handicrafts. See artisans

Heeley, Wilfred, 57, 110, 163

Heimskringla, 268, 269, 273. See also sources

Helen of Troy, M.s depiction of, 253-56

Helsinger, Elizabeth, 5, 166, 211, 214, 239, 243

heroism: and history, 12; M.'s depiction of, 141, 145, 158; and religion, 15

historicism: empathetic, 8-11, 123-25; in M.s work, 7-8, 73, 193-94, 249, 285; of Robert Browning, 172. See also history; medievalism; Scandinavia; sources

history: and accuracy, 123; and art, 11; contrasted with poetry, 169; inner truths of, 11-16; and material culture, 97-98; M.s interest in, 17, 19, 63, 101, 176, 265; and ordinary people, 12-13; theories of, 13-15. See also historicism; Hundred Years' War; medievalism; sources

Hopkins, Gerard Manley, 11, 7on2

humor: of Charles Faulkner, 53; of M. and Edward Burne-Jones, 47

Hundred Years' War, 6, 15-16, 193-94, 204, 209, 213, 216, 269. See also Ball, John; Froissart

Iceland: M.s admiration for, 87; M.s trip to, 57. See also Scandinavia

idle singers, $44,125,284-85$

imagery: M.'s use of, 81-82, 84-85, 89-90, $96,138,141,156,189-90,193,200,210-11$, 256, 260-63; of the Spasmodics, 72. See also flowers; nature

immortality: fellowship as, 126-28; granted by art, 119-20, 122

imperialism, British, 86, 129, 151-52. See also medievalism; socialism; war

imprisonment, in M.s work, 167-68, 207-8, 213, 220, 222, 282. See also castles; women intensity: M.'s admiration of, 45-46; in M.'s work, $169-70$

Irving, Washington, 273

isolation, felt by M., 29, 39, 42, 232. See also friendship

Jameson, Frederic, 8

Jauss, Hans Robert, 9-10n29, 221

Jehane, $185,215,218,227-28$

Joinville, Jean de, 90-91

justice, social, M.s commitment to, 1, 231. See also politics; socialism

juvenilia, of M., 72-73

Kant, Immanuel, 2n3, 119, 129

Keats, John, 161, 191, 213

Kelmscott Press, 39, 42, 105, 162, 211, 233 , 245,283

Kingsley, Charles, 44, 121, 152, 232

Kipling, Rudyard, 66

Kirchhoff, Frederick, 147-48

kisses, in M., 59, 205, 212. See also love; sexuality

Knight, Joseph, 247

labor: and art, 60, 175; and pleasure, 65, 99-100, 129. See also artisans; socialism

Lady Alice, 84, 183, 185, 205, 218

Landor, Walter Savage, 254

landscapes: M.'s attitude toward, 62-64, 108; M.'s depiction of, 71, 96, 108, 144, 260. See also nature

Lane, Joseph, 55

Latham, David, 253, 264, 277-78

Launcelot, 124, 179, 186-90, 221, 224, 226, 287-93; in Malory, 202

Le Bourgeois, John Y., 71n6, 81

Lefebvre, Henri, 198

LeMire, Eugene, 4, 109n43

Lethaby, William Richard, 56 
Levy, Amy, 184, 229

liminality, in M.s writings, 84, 92, 95-96, 118, 133, 139, 154, 193

Lindsay, Jack, 71n6, 81

literary criticism, by M., 60, 122-24

London, M.'s dislike of, 76-78

Lourie, Margaret, 90, 93, 160, 206n24, 217n38 love: art as embodiment of, 120; M.'s depiction of, 74, 91-92, 96, 131, 141, 146, $148-49,151,159-61,169,171,176,178-80$, 186-89, 196, 208, 211, 214, 229, 232, 260, 263, 279-81, 293; M.'s views of, 119-20, 123-24; M.'s quest for, 6-7; Rossetti's depiction of, 178; sublimated, 59; time defied by, 127; triangulated, 74, 201. See also marriage; sexuality

loyalty, among M.s protagonists, 143, 146-47, 151, 218, 222, 225-26, 232; in Malory, 288-89

Lushington, Godfrey, 110

Lushington, Vernon, 37, 49, 110

luxury, M.'s attack on, 102-3. See also simplicity

lyric poetry, of M., 258-64. See also forms, poetic

MacCarthy, Fiona, 21, 22n27, 27n52, 43n82, $55-56,66-67,243 \mathrm{n} 48$

Macdonald, Harry, 6, 57, 110. See also BurneJones, Georgiana

Mackail, J. W., 17n56, 18, 20, 21, 27, 28, 36-38, $39,45,51,55,56-57,67,70,104,166,170$, 171, 190-91, 231-32, 243, 249-50, 253, 285

magic, in M's writings, 216-17, 275, 279

Magnússon, Eiríkur, 36

Mallet, Paul, 271

Malory, Thomas: as source for M., 89, 94, $166-67,169,182,189,193,202-3,221$, 224, 232, 287-93; as source for Rossetti, 176-77

Mandeville, John, 267

Marlborough College, 19, 22, 23-24, 29, 70

marriage: of M., 29, 232; M.s views on, 195,
221, 284; and socialism, 228; Victorian views on, 184. See also gender; love; sexuality; women

Marx, Eleanor, 229

Marx, Karl, 99

masons, 131-36. See also artisans

Matrimonial Causes Act, 184, 221. See also Divorce Law of 1857; marriage

medievalism: of M., 2-3, 6-8, 17, 85-86, 90, $98,101,128,144,153,159,161,169,172$, 193-94, 196-98, 200, 219-20, 241-43, 247-48, 251, 275-76, 279, 281; of Rossetti, 176-77, 180; of Tennyson, 7, 166-69, 194, 237

melancholy: in M., 61, 167; in Poe, 191 memorials, creation of, 75, 150, 152 memory, and architecture, 99-100, 105

Meredith, Owen. See Bulwer-Lytton, Robert meter: M.s use of, 83, 92-93, 227-28, 250, 253, 267, 273, 275; Robert Browning's use of, 122; the Spasmodics' use of, 72. See also rhyme; rhythm; style

Millais, John Everett, 211n3o

Milman, Henry Hart, 14, 85-86

ministry: M.'s interest in, 5, 52, 85; M.'s rejection of, 63-64, 107, 109

modesty, of M., 58-60, 62, 121

monologues: M.'s use of, 94, 122, 160, 172-73, 175-76, 196, 221, 228-30, 238-39, 251, 253; Robert Browning's use of, $175-76,212$; Tennyson's use of, 163. See also forms, poetic

Morris, Emma, 20, 22-23, 24-25, 28-29, 70, $71,78,81$

Morris, Henrietta, 20

Morris, May, 4, 5, 18, 19, 53-54, 70, 72, 73, $82-83,194,248,253,258,264,272-73$, 274-75, 276-77

Morris, siblings of, 20

Morris, Stanley, 20

mourning, M.s depiction of, 74, 155-57

Mulvey, Laura, 222

music, M.s interest in, 26 
mysticism, in M.'s writings, 46, 107, 119, 121, 203

narrative, in M.'s works, 90, 125, 130, 132-33, 135-37, 159, 175, 251, 255, 265, 272-73, 281; complex, 136-41, 143, 147, 149, 158, 175; temporally dislocated, $131-33,137-38$, 153,158

nature: M.'s admiration of, 24, 26-27, 45, 54, $62,73,78,82,99,101-2,107-8,121,129$, 219; M.s depiction of, 81-82, 87, 134, 144, 167-68, 224. See also flowers; imagery; landscapes

Notre Dame Cathedral (Paris), 106. See also Amiens; architecture; churches; medievalism; Rouen; travel

obscurity: attributed to Browning's poetry, 122-23, 250; attributed to M.'s poetry, 170, 234-40, 242-44, 249, 251, 254, 256. See also imagery; style

originality, of M.s work, 240-41, 246, 250-51

Orpheus, 2, 125; Burne-Jones' drawings of, 48

Oxford: curricular changes at, 52; M.'s time at, 29-38, 68, 70; politics of, 56. See also Brotherhood; friendship

Oxford and Cambridge Magazine, 2, 6, 42-44, 57, 59, 70, 72, 87-88, 91-92, 94, $96,104,106,110-13,121-24,130,136,144$, $150,153,162,176,200,210,217,233,250$

Oxford Movement, 83

painting: by M., 64-65; and poetry, 234; by Rossetti, 176

Pater, Walter, 11-12, 112, 160, 247, 293

Perrine, Laurence, 293

Pinkney, Tony, 54, 56

pleasure: in the creation of art, 99-100; in labor, 65, 99-100, 129; in writing, 60

Poe, Edgar Allan: as influence on M., 162, 190-93; "Dream-Land," 192; "Eldorado," 192-93; “The Haunted Palace," 192

poetry: contrasted with history, 169; as heroic, 2-3, 6; M.'s defense of, 60; M.'s definition of, 122; M.'s early attempts at, 69-71; and music, 61; and painting, 234; "unmediated," 258

politics: as absent from M.'s poetry, 160-61; and art, 104, 174; in M.'s works, 144-50, 175-76, 220-22. See also socialism

prayers, in M.'s works, 216-17, 225

Pre-Raphaelites, 5, 67, 77, 104-5, 122, 166, $220-21,233-34,245-46$

Prescott, William, 273

present, entrapment in, 10-11. See also historicism; medievalism

Price, Cormell, 4, 22, 30, 35, 40-43, 46, 49, 51, $54,56-68,105,107,109-110$

Prinsep, Val (Valentine), 56

Puritanism, as M.'s religious background, 19,22

Purkis, John, 107

quests: in M.s poems, 94, 142, 167, 193, 208, 210, 282

railroads, M.s dislike of, 63

reader-response criticism, 9-12, 60-61, 112, $123,220-21$

reading aloud, by $M ., 58,88,162$ redemption, in M., 94, 107, 143, 219, 281 religion: and art, 98, 109; Charles Faulkner's attack on, 55; critiques of, 14; and heroism, 15; M.'s attitude toward, 3-5, 25-26, $83-85,109,128,150,193,232$; Oxford controversies about, 108-9; in Rossetti's work, 180 ; and secular meaning, 3 ; and socialism, 128

repression: in the Arthurian cycle, 181; and artistic creation, 131; in M.'s heroines, 219, 221-222, 225

rescue, of women in M., 3, 94, 164, 210, 218, 221,224

restoration, architectural, opposed by M., 97-98, 106, 114-15, 120, 125. See also Society for the Protection of Ancient Buildings

Rethel, Alfred, 112 
reviews, of M.'s work, 7, 160-61, 169-70, 194, 233-48, 251, 264, 282; M.'s reaction to, 245-46, 248-49

revisions. See composition, M.'s process of rhyme, M.'s use of, 6o-61, 89, 91-92, 210, 242, 245. See also style

rhythm: M.'s use of, 93, 165, 200, 210-11, 214, 227-28; Tennyson's experiments in, 163. See also meter; style

Romanticism, as influence on M., 77

Rossetti, Christina, 218n41, 233

Rossetti, Dante Gabriel, 64-65, 77, 88, 162, 191, 193, 214, 232-34, 237-38, 246, 249-50, 260-61, 263, 283; "Blessed Damozel," 178-79; "The Choice," 178; drawings as basis for M.'s poems, 177-78; as influence on M., 170, 176-80

Rossetti, William Michael, 246

Rouen, M.'s visit to, 64, 108. See also Amiens; architecture; churches; medievalism; Notre Dame; travel

ruins, M.s depiction of, 75, 83-84

Ruskin, 8, 11, 44, 86-87, 110, 116-17, 119-20, $122,132,174$; as admirer of M., 245-46; as influence on M., 104-7; The Seven Lamps of Architecture, 104-5, 116-17, 132

Scandinavia, M.'s interest in, 86-87, 121, 144-47, 251, 267-70, 282. See also Iceland; medievalism; travel

Scheu, Andreas, 18, 24, 36, 71

Schleiermacher, Friedrich, 9

Scott, Dixon, 160

secularism, of M., 87, 107, 109. See also religion; socialism

Sedgwick, Eve, 222

sexuality: M.'s depiction of, 96, 195-96, 200-201, 203, 219, 274; M.'s views on, 195; and mysticism, 203. See also gender; love; women

Sharmon, William, 24

Shelley, Percy Bysshe, 236, 245; "To a Skylark," 61

Shklovsky, Viktor, $200 n 8$
Siddal, Elizabeth, 209

Silver, Carole, 211n30, 229n54, 239, 243

simplicity, M.'s call for, 99, 102, 129

Sismondi, Jean Charles Léonard de, 14-15

Skelton, John, 236, 238-40, 242n37, 248

skepticism. See religion

slavery: as necessary for luxury, 103; and religion, 5,14

socialism: and aesthetics, 251; and art, 99; Charles Faulkner's attitude toward, 54-55; Edward Burne-Jones' hostility toward, 48; and human nature, 1-2, 17; and marriage, 228; M.'s early interest in, 21; and M.'s view of artisans, 120; and religion, 128

Socialist League, 52, 54-55, 65, 71, 101, 128, 231

Society for the Protection of Ancient Buildings, 39, 65, 97-98, 105-6, 109, 114, 128

sonnets, M.'s writing of, 92. See also forms, poetic

sources, for M., 2, 13, 15-17, 44, 89-90, 93, $145,159-94,202-4,206,211,232,239,251$, 254, 265-71, 273-75, 278-79, 282, 285, 287-93. See also Froissart; historicism; Heimskringla; Malory; medievalism; Scandinavia

Spasmodics, 72, 169, 236

Spatt, Hartley, 133

Street, George Edmund, 30, 106

style, of M., 25, 88, 161-62, 171-73, 176, 234, 236-37, 239, 245, 258. See also colors; flowers; imagery; meter; rhyme; rhythm

sublimation: by M., 29, 81; in M.'s works, 59, $73,95-96,146,203$

suffering, of M.s protagonists, 73, 76, 113, 119-20, 142-43, 161, 201, 211, 213, 219-20, 246, 282. See also failure

Swinburne, Charles Algernon, 229, 233, 246, 251, 279

Tannhäuser, 278-79

temper, of M., 27-28, 47, 53

Tennyson, Alfred Lord, 122, 134, 137, 162-63, 
$186,193,229,232,236-38,246,249-50$, 268, 270; contrasted with M., 7; as didactic, 175; "In Memoriam," 92-93; as influence on M., 43-44, 162-69; "The Lady of Shalott," 162, 164-65, 214, 234; "Locksley Hall," 163; Maud, 162, 168-69, 175, 181; medievalism of, 7, 194, 237, 241; “Oenone," 166; "Oriana," 163-64; politics of, 175; The Princess, 166; "Sir Launcelot and Queen Guinevere," 167

Tieck, Ludwig, 278

time, M.'s treatment of, $63,87,126-27,130-33$, 137-38, 142-43, 147-48, 153, 158. See also narrative

transcendence, in M., 16, 93, 99, 150

travel, of M. with his friends, 53-54, 57, 6164, 67, 106-9. See also Amiens; Iceland; Notre Dame; Rouen; sources

vengeance, M.s depiction of, 131, 154-55, 205, 270

Venus, M.s depiction of, 279-81

Victorian Era, gender roles in, 219, 221, 224, 228-29. See also gender; marriage; sexuality; women

villains, in M.'s work, 174-75

violence, M.'s depiction of, 129, 153-54, 157, 172-75, 196-99, 216-17, 245. See also war

Viollet le Duc, Eugène, 114 visions, in M.'s poetry, 77, 80-81. See also dreams

Walker, Emery, 36

war, M.s attitude toward, 6-7, 15-16; M.'s depiction of, 12, 85-86, 126-27, 145-46, 151-52, 172, 205, 208, 211-12, 257, 282. See also violence

Watson, Rosamund Marriott, 229

Webb, Philip, 30, 36, 49, 51, 53, 54, 56-57, 97n1

Whitla, William, 83

Whyte, William, 49, 51-52

Wilde, Oscar, "Ballad of Reading Gaol," 80

Wollstonecraft, Mary, 219

women, in M.'s work, 80, 141, 149, 179, 193-94, 195-230; imprisonment and rescue of, 94, 164-65, 167-68, 185, 207-8, 213, 218, 220, 222, 224, 229; suffering of, 149-50, 161, 201, 219, 274. See also gender; love; sexuality

Woolner, Thomas, 246

Wordsworth, William, “The Thorn," 72, 76

Wright, Peter, 254nn83-84

Yeats, William Butler, 160

Yonge, Charlotte M., 44-45, 232 